Florida International University FIU Digital Commons

$6-4-2010$

\title{
The Influence of Phosphorus on Periphyton Mats from the Everglades and Three Tropical Karstic Wetlands
}

Josette M. La Hee

Florida International University, jolah76@yahoo.com

DOI: $10.25148 /$ etd.FI10081215

Follow this and additional works at: https://digitalcommons.fiu.edu/etd

\section{Recommended Citation}

La Hee, Josette M., "The Influence of Phosphorus on Periphyton Mats from the Everglades and Three Tropical Karstic Wetlands" (2010). FIU Electronic Theses and Dissertations. 251.

https://digitalcommons.fiu.edu/etd/251 


\title{
FLORIDA INTERNATIONAL UNIVERSITY \\ Miami, Florida
}

THE INFLUENCE OF PHOSPHORUS ON PERIPHYTON MATS FROM THE EVERGLADES AND THREE TROPICAL KARSTIC WETLANDS

\author{
A dissertation submitted in partial fulfilment of the \\ requirements for the degree of \\ DOCTOR OF PHILOSOPHY \\ in \\ BIOLOGY
}

by

Josette Marie La Hée

2010 
To: Dean Kenneth G. Furton

College of Arts and Sciences

This dissertation, written by Josette Marie La Hée, and entitled The Influence of Phosphorus on Periphyton Mats from the Everglades and Three Tropical Karstic Wetlands, having been approved with respect to style and intellectual content, is referred to you for judgment.

We have read this dissertation and recommend that it be approved.

Jennifer Richards

Joel Trexler

James Fourqurean

Leonard Scinto

Evelyn Gaiser, Major Professor

Date of Defense: June 4, 2010

The dissertation of Josette Marie La Hée is approved.

Dean Kenneth G. Furton College of Arts and Sciences

Interim Dean Kevin O’Shea

University Graduate School

Florida International University, 2010 


\section{DEDICATION}

This dissertation is dedicated to my parents, Franklyn A. La Hée and Sonia M. Brown

La Hée, who convinced me that I could do anything my heart desired and then stood by my side as I tried. This accomplishment is as much yours as it is mine. Thank you. 


\section{ACKNOWLEDGMENTS}

Any undertaking of this sort requires a community effort. Mentors, peers, administrators, funding sources, friends and family each contribute to the final product, some without even being aware of their contribution or its significance. This is my opportunity to, in some small way, say thank you to this community.

I would like to start by thanking my major advisor, Dr. Evelyn Gaiser for her guidance and assistance throughout this process. As an advisor, Dr. Gaiser exceeded her required duties by offering academic advice and support, being patient with me as I explored new ideas and being firm but kind when it was necessary to rein me in. As a mentor, she demonstrated the best of academia: a curious and enthusiastic scientist; a dedicated and inspiring teacher; a compassionate and understanding soul. I will forever be grateful for all she has taught me and as I move forward I will take those lessons with me. Thank you Evelyn!

It is often said that dissertation projects evolve over time. This was indeed my experience, but I also found that as my dissertation evolved, so did my dissertation committee. I would therefore like to thank all the people who, at one time or another, were kind enough to act as part of my advisory committee: Dr. Michael Ross, Dr. Thomas Philippi, Dr. Ann Hartley, Dr. Javier Francisco-Ortega, Dr. Grenville Draper and 
Dr. Daniel Childers. My final committee members, Dr. Jennifer Richards, Dr. Joel Trexler, Dr. James Fourqurean, Dr. Leonard Scinto and Prof. Eugene Stoermer, each provided valuable feedback during the writing process and offered useful insights that greatly improved the final product. I thank them all.

Field and lab work formed a significant portion of the effort toward completing this project and there are several people who assisted in that effort. The members of the FIU Periphyton lab are first and foremost on this list. Each of the individuals comprising this group have at one time or another accompanied me to the field, assisted with lab work, put up with my numerous questions, offered support, food and a hug when necessary. I have been extremely lucky to be associated with such a wonderful group of people, who I consider friends as well as colleagues. To this group I say a heartfelt thank you, and a special thanks to Franco Tobias, Ania Wachnicka, Rafael Travieso and Christine Taylor for going above and beyond.

This project also involved field work in Jamaica, Belize and Mexico and so I would like to thank my international field crew as well: the Sian Ka'an Biosphere Reserve in Quintana Roo, Mexico and Lamanai Outpost in Orange Walk, Belize for facilitating site access and supporting this research; Clifton Ruehl, Raul Urgelles, William Loftus, Joel Trexler and collaborators from Universidad Nacional Autónoma de México for their assistance with the collection of field data from Mexico and Belize; Kimberly John, Philip Rose and the La Hée family for their assistance with data collection in Jamaica. I am also indebted to Dr. Marina Potapova of the Diatom Herbarium at the Ruth Patrick Center in the Philadelphia Academy of Sciences, 
Pennsylvania, U.S.A, for her patience and kindness while assisting me with diatom identifications.

None of this research would have been possible without funding, and so I thank the multiple foundations that provided financial assistance for this project: The Phycological Society of America Grant in Aid of Research 2007, Florida International University Graduate Student Association Research Grant 2007, Latin American and Caribbean Center Research Travel Grant 2006, Society of Wetland Scientists 2006, Garden Club of America Scholarship 2006, Iowa Lakeside Laboratory Merit Scholarship (2004), Christina Menendez Fellowship for Everglades Research 2004, Enhanced Teaching Assistantship - Department of Biological Sciences (2003 to 2007). I must herein also thank my parents for offering financial support when other funding sources fell short.

I would like to mention the FIU biology personnel who assist with everyday administrative issues and are kind enough to not lock their doors when they see me coming. My special thanks to the ones I have had to bother the most: Maria Helen Forlong, Erin Dowd and Oria Solis. Thanks also to Dr. Lidia Kos (Biology Graduate Program Director) and Dr. Maureen Donnelly (Associate Dean in the College of Arts and Sciences), who do their job and do it well.

I am lucky to have a wide network of friends who have not only offered support in my academic endeavours, but have enriched my life in numerous ways, for which I am grateful. I am happy to say that my list of friends is too long to include here, but I feel I must thank a few by name. Jennifer Lewis, Zayda Halun, Laura May-Collado and Bryan Dewsbury started this FIU journey with me, what seems like eons ago, and have been a 
constant and consistent source of love and laughter: we started as peers and now we are family. I thank Lorraine Abrams, Felipe Zuñiga and Ania Wachnicka for their friendship, especially for the visits and long talks that helped to get me though rough days. In the same breath I thank Dr. José Sandoval, whose presence in my life has been a true blessing. I know that without his kindness, compassion, patience and positivity I would not have finished this journey. It is with great humility and sincerity that I say thank you.

I smile as I thank my friends from home who have been through similar journeys with me before and who remain as supportive and encouraging as always. Your friendships are as dear to me now as they were 10 years ago: Kimberly John, Damian Nesbeth, Lois Morgan, Hugh Lounges, Stacey McKoy, Philip Rose and Peter Edwards. Here I also thank Norman Kitchen, whose presence has been a great comfort to me, especially during the final lap of this journey. I am blessed to have found you.

Finally and with profound humility, I thank my beloved family. My brothers François and René La Hée have ever been the big brothers who I trailed after as a toddler, was protected by as a teenager and whose respect I tried to earn as an adult. I thank you for your support and I hope I have made you proud. My parents, Franklyn A. La Hée and Sonia M. Brown-La Hée, represent all that good parents should be. I cannot find the words to express the depth of my affection, love and respect for these two souls. You have been a constant source of strength and inspiration and I believe that everything in me that can be considered good has come directly from you both. You are what I aspire to be and if I attain even a fraction of your goodness, I would have achieved greatness. Thank you. Thank you. Thank you. 


\title{
ABSTRACT OF THE DISSERTATION \\ THE INFLUENCE OF PHOSPHORUS ON PERIPHYTON MATS FROM THE EVERGLADES AND THREE TROPICAL KARSTIC WETLANDS
}

by

\author{
Josette Marie La Hée
}

Florida International University, 2010

Miami, Florida

\section{Professor Evelyn Elaine Gaiser, Major Professor}

The distinctive karstic, freshwater wetlands of the northern Caribbean and Central American region support the prolific growth of calcite-rich periphyton mats. Aside from the Everglades, very little research has been conducted in these karstic wetlands, which are increasingly threatened by eutrophication. This study sought to (i) test the hypothesis that water depth and periphyton total phosphorus (TP) content are both drivers of periphyton biomass in karstic wetland habitats in Belize, Mexico and Jamaica, (ii) provide a taxonomic inventory of the periphytic diatom species in these wetlands and (iii) examine the relationship between periphyton mat TP concentration and diatom assemblage at Everglades and Caribbean locations.

Periphyton biomass, nutrient and diatom assemblage data were generated from periphyton mat samples collected from shallow, marl-based wetlands in Belize, Mexico and Jamaica. These data were compared to a larger dataset collected from comparable sites within Everglades National Park. A diatom taxonomic inventory was conducted on the Caribbean samples and a combination of ordination and weighted-averaging modeling techniques were used to compare relationships between periphyton TP 
concentration, periphyton biomass and diatom assemblage composition among the locations.

Within the Everglades, periphyton biomass showed a negative correlation with water depth and mat TP, while periphyton mat percent organic content was positively correlated with these two variables. These patterns were also exhibited within the Belize, Mexico and Jamaica locations, suggesting that water depth and periphyton TP content are both drivers of periphyton biomass in karstic wetland systems within the northern Caribbean region.

A total of 146 diatom species representing 39 genera were recorded from the three Caribbean locations, including a distinct core group of species that may be endemic to this habitat type. Weighted averaging models were produced that effectively predicted mat TP concentration from diatom assemblages for both Everglades $\left(\mathrm{R}^{2}=0.56\right)$ and Caribbean $\left(\mathrm{R}^{2}=0.85\right)$ locations. There were, however, significant differences among Everglades and Caribbean locations with respect to species TP optima and indicator species. This suggests that although diatoms are effective indicators of water quality in these wetlands, differences in species response to water quality changes can reduce the predictive power of these indices when applied across systems. 


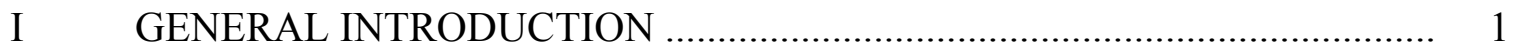

Literature cited ........................................................... 7

II PHOSPHORUS AND HYDROLOGY AS DRIVERS OF PERIPHYTON BIOMASS IN FOUR TROPICAL KARSTIC WETLAND SYSTEMS ............ 13

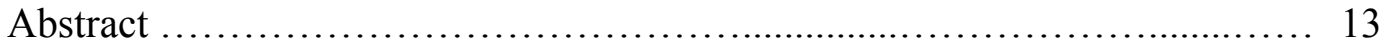

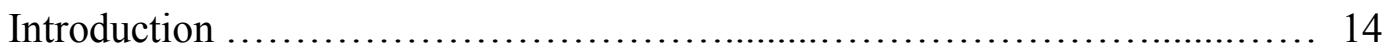

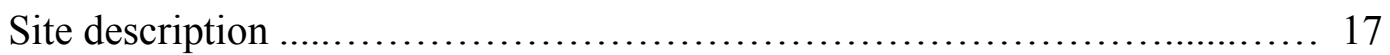

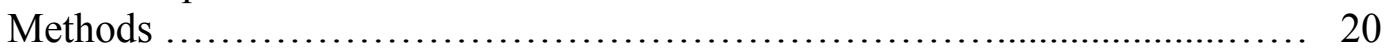

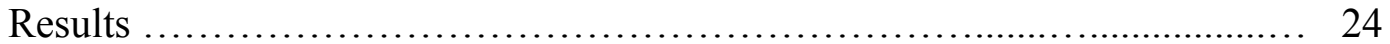

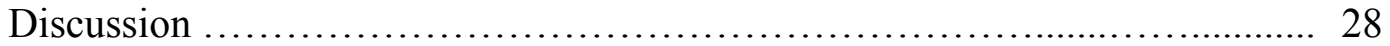

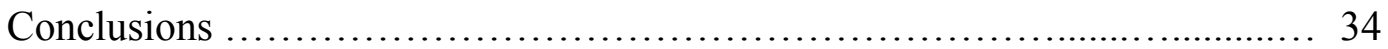

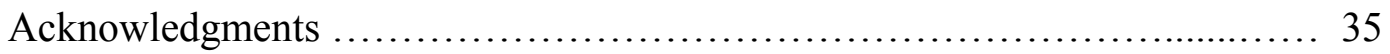

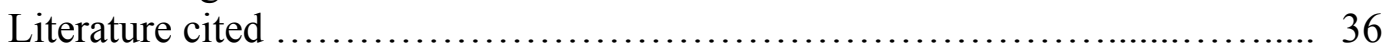

III DIATOM SPECIES OF CALCITIC PERIPHYTON MATS FROM KARSTIC WETLAND HABITATS IN BELIZE, MEXICO AND $\begin{array}{ll}\text { JAMAICA } & 48\end{array}$

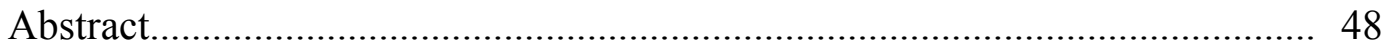

Introduction ............................................................ 49

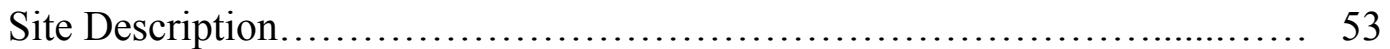

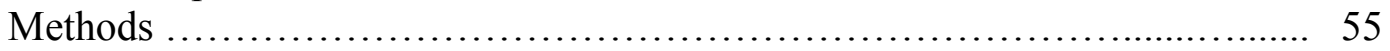

Results and Discussion .................................................. 58

Acknowledgments ........................................................ 86

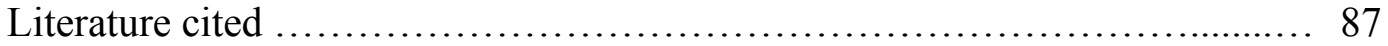

IV PERIPHYTIC DIATOM ASSEMBLAGES AS INDICATORS OF

WATER QUALITY IN THE EVERGLADES AND THREE TROPICAL

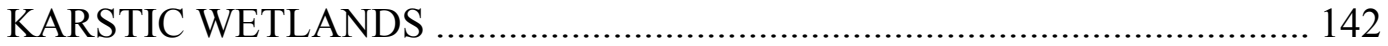

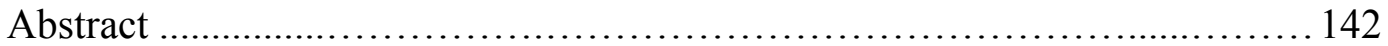

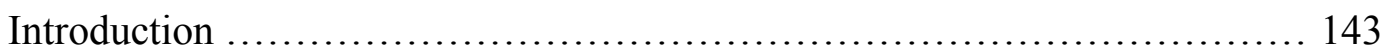

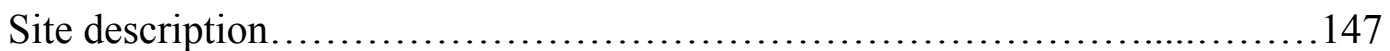

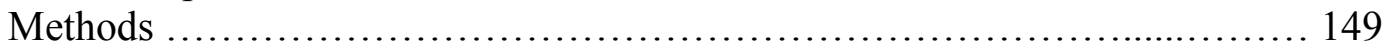

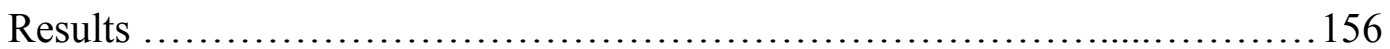

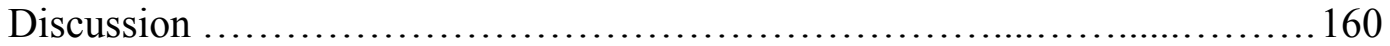

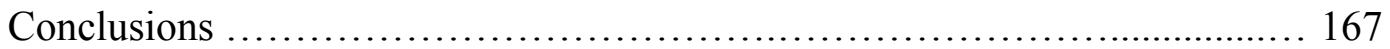

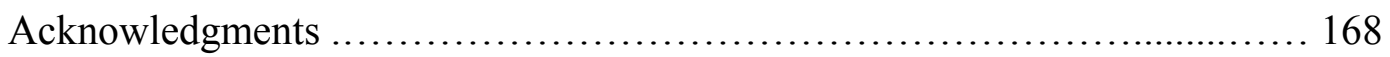

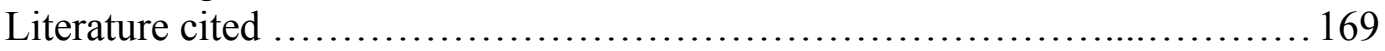


$\mathrm{V} \quad$ GENERAL CONCLUSIONS.......................................... 196

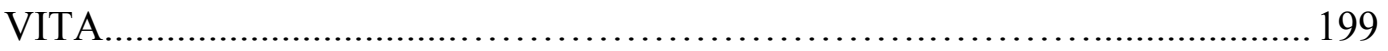




\section{LIST OF TABLES}

TABLE

PAGE

$2-1$ Location of Caribbean sampling sites, presented as latitudinal and longitudinal bounding GPS coordinates of sampling sites within each location.

2-2 Number of sites sampled (N), water characteristics and periphyton attributes for each location during wet and dry periods. Average values are given along with standard deviation values in brackets. Missing data are indicated with a dash $(-)$

3-1 Location of Caribbean sampling sites, presented as latitudinal and longitudinal bounding GPS coordinates of sampling sites within each location.

3-2 Number of sites sampled (N), water characteristics and periphyton attributes for each location during wet and dry periods. Average values are given along with standard deviation values in brackets. Missing data are indicated with a dash (-).

3 -3 List of non-rare species showing the number of locations $(\mathrm{N})$ at which each species was found, along with an indicator of average percentage abundance at each location: Belize (B), Mexico (M) and Jamaica (J). Rare (<1\%): *; Uncommon ( 1 to $<5 \%$ ): **; Common ( 5 to $<20 \%$ ): ***; Abundant $(>20 \%)$ : $* * * *$. Species absence from a location is indicated with a dash $(-)$....

3-4 Average per-site species richness (S) and diversity (H) for all locations. Standard deviations are indicated in parentheses

4-1 Location of Caribbean sampling sites, presented as latitudinal and longitudinal bounding GPS coordinates of sampling sites within each location

4-2 Number of sites sampled (N) and water characteristics for each location during wet and dry periods. Average values are given along with standard deviation values in brackets. Missing data are indicated with a dash (-). 
4-3 List of non-rare species ( $>1 \%$ average abundance) showing the number of locations $(\mathrm{N})$ at which each species was found, along with its average percentage abundance at each location: Everglades (E), Belize (B), Mexico (M), Jamaica (J) and Caribbean locations combined (C). Species absence from a location is indicated with a dash $(-)$. TP optimum and tolerance values (TP Opt (Tol)) are given for the 22 species that were present at all locations and indicator species (I) are identified as indicating high or low TP for the Everglades ( ${ }^{* *}=$ high TP; ${ }^{*}=$ low TP) and Caribbean $(" \mathrm{t}=$ high TP; $\mathbf{t}=$ low TP $)$ locations...

4-4 Average per-site species richness (S) and diversity (H) for all sites. Standard deviations are indicated in parentheses. Significantly low values $(p<0.001)$ are indicated with an asterisk $\left(^{*}\right)$ 


\section{LIST OF FIGURES}

FIGURE

PAGE

2-1 Map of northern Caribbean region showing the four sampling locations for this study

2 - 2 Bar graphs showing average values for all measured variables during wet and dry sampling periods at Everglades (E), Belize (B), Mexico (M) and Jamaica $(\mathrm{J})$ sites. Graphs were created using transformed values for each variable and $\mathrm{X}$ and $\mathrm{Y}$ axes are scaled to facilitate transformed values. Error bars represent one standard deviation. Columns marked with an asterisk indicate a significant difference (ANOVA and Tukey's test, $\mathrm{p}<0.05$ ) between average values during the wet and dry period

2-3 Scatterplots showing relationships between water depth and all other measured variables at each site. Graphs were created using transformed values for each variable. $\mathrm{X}$ and $\mathrm{Y}$ axes were scaled to facilitate transformed values. Two sets of regression lines and $\mathrm{R}^{2}$ values are shown. The dashed line describes data from all the Everglades sites and the solid line describes the combined dataset from the Caribbean sites. $\mathrm{R}^{2}$ values marked with an asterisk indicate a significant correlation between the variables $(\mathrm{p}<0.01)$.

2-4 Scatterplots showing relationships between periphyton TP and all other measured variables at all sites. Graphs were created using transformed values for each variable. $\mathrm{X}$ and $\mathrm{Y}$ axes were scaled to facilitate transformed values. Two sets of regression lines, equations and $\mathrm{R}^{2}$ values are shown. The dashed line describes data from all the Everglades sites and the solid line describes the combined dataset from the Caribbean sites. $\mathrm{R}^{2}$ values marked with an asterisk indicate a significant correlation between the variables $(p<0.001)$.

2 - 5 Principle component analysis joint plots of Everglades sites (a) and Caribbean sites (including M, B, J data) (b). Vectors on each plot represent the direction and strength of the relationship among environmental variables and periphyton attributes............................................................

3-1 Benthic (a) and epiphytic (b) periphyton mat specimens collected from karstic marsh habitats. 
3 - 2 Map of northern Caribbean region showing the four sampling locations for this study. The Everglades location is included for comparison.

4-1 Benthic (a) and epiphytic (b) periphyton mat specimens collected from karstic marsh habitats

4-2 Map of northern Caribbean region showing the four sampling locations for this study

4-3 Rarefaction curves generated for Everglades samples (E), Belize samples (B), Mexico samples (M), Jamaica samples (J) and a composite of the Caribbean samples $(\mathrm{C})$.

4-4 NMDS plot showing dissimilarity between diatom assemblages from Everglades (E), Belize (B), Mexico (M) and Jamaica (J) locations $($ Stress $=0.17)$. The vector representing the direction and strength of the relationship between mat TP and diatom assemblage dissimilarity is shown

4-5 NMDS plot showing dissimilarity between high and low TP diatom assemblages from (a) Everglades (Stress $=0.19$ ), (b) a composite of the Caribbean locations $($ Stress $=0.12$ ). The vector representing the direction and strength of the relationship between mat TP and diatom assemblage dissimilarity is shown

4-6 Scatter plot showing the relationship between diatom inferred periphyton mat TP concentration and observed periphyton mat TP concentration for Caribbean (-) $\left(\mathrm{R}^{2}=0.85, \mathrm{RMSE}=66.1 \mu \mathrm{g} \mathrm{TP} \mathrm{g}{ }^{-1}\right)$ and Everglades $(\mathbf{O})$ sites $\left(\mathrm{R}^{2}=0.56, \mathrm{RMSE}=113.4 \mu \mathrm{g} \mathrm{TP} \mathrm{g} \mathrm{g}^{-1}\right)$.

4-7 Scatter plot showing (a) the relationship between Everglades and Caribbean diatom species TP optima $\left(\mathrm{R}^{2}=0.55\right)$ and $(\mathrm{b})$ the relationship between Everglades and Caribbean ranked diatom species TP optima $\left(\mathrm{R}^{2}=0.55\right)$. 


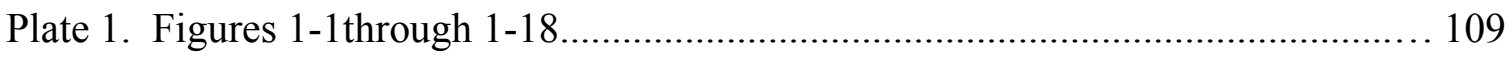

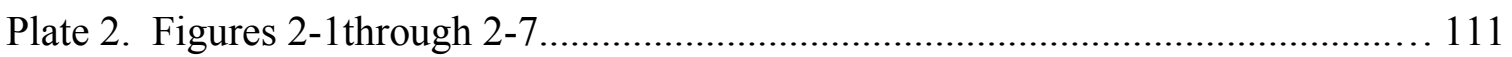

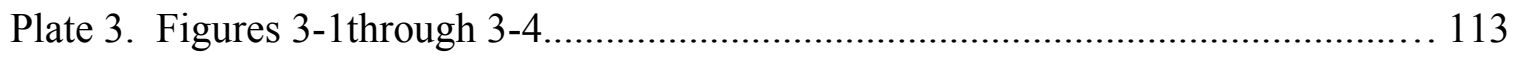

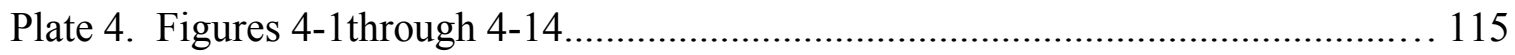

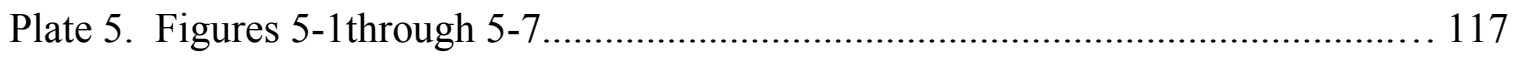

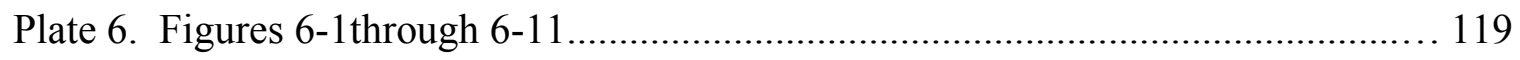

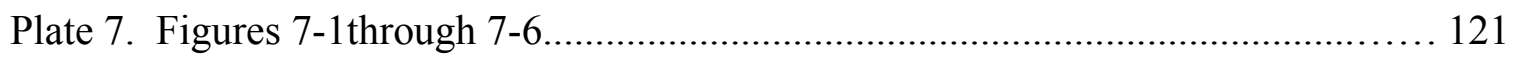

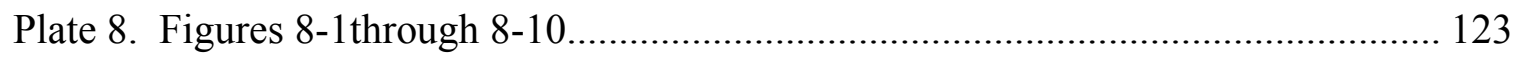

Plate 9. Figures 9-1through 9-13

Plate 10. Figures 10-1 through 10-10.................................................................. 127

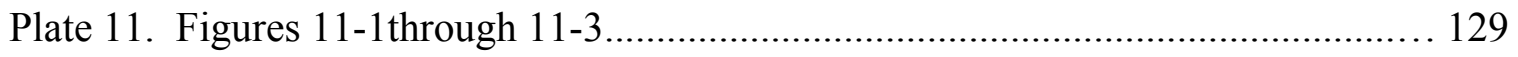

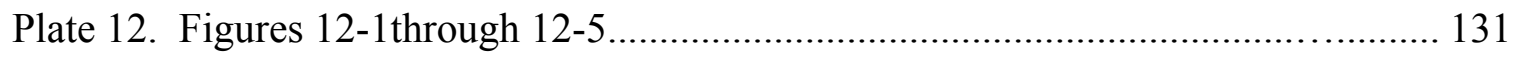

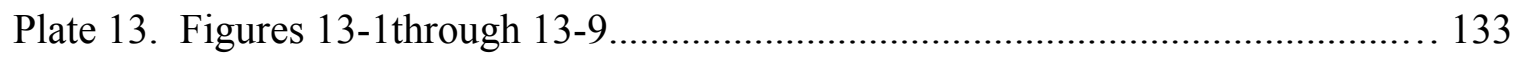

Plate 14. Figures 14-1through 14-7........................................................................ 135

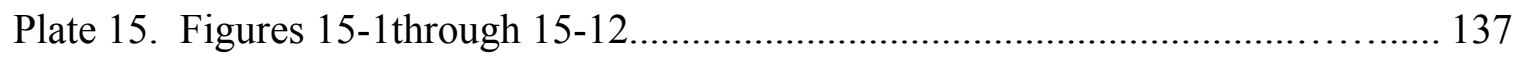

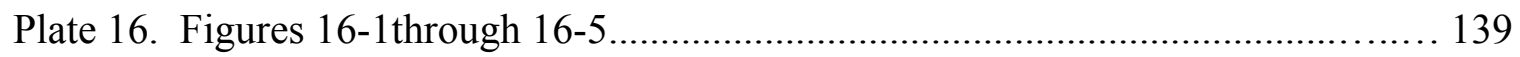

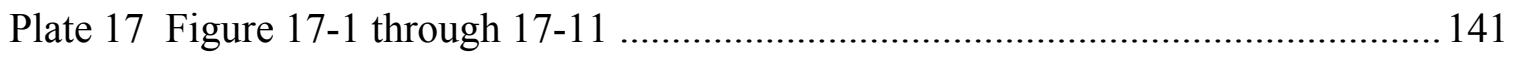




\section{CHAPTER I}

General Introduction

Karstic wetlands can be found throughout the world and collectively comprise a distinctive set of habitats that are all defined by the dominance of limestone in the underlying bedrock. Within the Caribbean and Central American region, freshwater karstic wetlands occur as expanses of inundated coastal and inland plains, underlain by ancient limestone bedrock. Topographical and hydrological variation greatly influence vegetation assemblages across these wetland landscapes, producing a patchwork of habitat types that range from elevated pine rockland forests to deep-water sloughs. Included among these varied habitat types are extensive areas of shallow, marl-based marshes, which are characterized by low water phosphorus $(\mathrm{P})$ concentration $\left(<10 \mu \mathrm{g} \mathrm{\textrm {L } ^ { - }}\right.$ ${ }^{1}$ ), a distinctive macrophyte community and the prolific growth of calcitic, cyanobacterial mats known as periphyton mats (Browder et al., 1994; Cooper et al., 1999; Gunderson, 1994; Rejmánková and Komárková, 2000; Novelo and Tavera, 2003; Gaiser et al., 2006). Although the presence of these mats has been confirmed from multiple areas within the Caribbean and Central American region (Rejmánková et al., 2004), most of the taxonomical and ecological research has been conducted in the southern Florida Everglades, one of the most intensely studied wetland ecosystems in the western hemisphere. The historic Everglades wetland ecosystem once covered an expanse of approximately $10,000 \mathrm{~km}^{2}$, however, industrial and agricultural developments and the resultant alterations in the spatial expanse, water quality and natural flow regime, have 
led to the reduction of "natural" wetland area to just over half its original size (Willard et al., 2001; Winkler et al., 2001). The system still remains the largest contiguous wetland system in North America and one of the largest freshwater wetlands in the world (Mitsch and Gosselink, 2000).

Periphyton mats within this system were first described in 1928 by DachnowskiStokes as part of a study on coastal subsidence and subsequent work has served to characterize the composition and structure of these mats, as well as document the variations in mat types across habitat types (e.g. Loveless, 1959, Brock, 1970; Van Meter-Kasanof, 1973; Wilson, 1974; Wood and Maynard, 1974; Gleason and Spackman, 1974; Browder, 1982; Raschke, 1993). More recently, in light of concerted efforts towards the development of monitoring and restoration strategies within the Everglades, periphyton studies have focused on the potential use of periphyton mats as indicators of environmental stress and recovery (McCormick and Stevenson1998; Noe and Childers, 2007; Gaiser et al., 2004).

Calcitic periphyton mats are structurally dominated by filamentous cyanobacteria (primarily Schizothrix spp. and Scytonema spp.), which form an interwoven network in which diatoms, green algae, desmids, heterotrophic bacteria and fungi grow amid polysaccharide mucilage strands and interstitial deposits of calcium carbonate (Van Meter-Kasanof, 1973; Swift and Nicholas, 1987; Donar et al., 2004; Stal, 2000; Rejmánková and Komárková, 2000). Diatoms are a particularly important periphyton mat component, contributing to both mat form and function. Taxonomic studies have identified a distinctive assemblage of diatom species (including Brachysira neoexilis, Encyonema evergladianum, Encyonema spp., Fragilaria syngrotesca, Mastogloia smithii 
var. lacustris, Mastogloia smithii, Navicula cryptotenella, Nitzschia palaea and Nitzschia serpentiraphe) which has not been reported from other habitat types and is possibly endemic to subtropical/tropical freshwater karstic wetlands (Slate and Stevenson, 2000 and 2007; Gaiser et al.2006). The organic matrix of mucopolysaccharide threads produced by certain species of attached and motile diatoms (e.g. Gomphonema spp. and Mastogloia smithii) encourages periphyton mat cohesion and, along with cyanobacterial mucilage sheaths, aid in resistance to mat desiccation (Azim and Asaeda, 2005; Donar et al., 2004; Thomas et al., 2006; Gaiser et al., 2010). The copious production of glycocalyx also serves as an extracellular organic reservoir of nutrients that may sustain microbial activity under oligotrophic conditions and stimulate microbial heterotrophic activity following extended periods of desiccation (Gaiser et al., 2010; Hagerthey et al., in press).

Everglades periphyton mats are among the most productive in the world, with reported annual net primary production rates of greater $10,000 \mathrm{~g} \mathrm{C} \mathrm{m}^{-2} \mathrm{year}^{-1}$, which in some areas, exceed production rates of macrophytic vegetation (Browder et al., 1994; Goldsborough and Robinson, 1996; Ewe et al., 2006). The various algal, bacterial and detrital components of these mats comprise a significant food source for microinvertebrates, macroinvertebrates and fish, and the intricate structural architecture of these mats provides microhabitats for these organisms, many of which are able to persist during dry periods by using the moist mat layers as a refuge (Williams and Trexler, 2006; Liston et al., 2008). Periphyton mats are also important biogeochemical regulators, which facilitate the deposition of calcium carbonate throughout the system, influence the production of detrital floc (Neto et al., 2006) and are responsible for diurnal and annual fluctuations in water chemistry (McCormick et al., 2001; Munyon, in prep.). 
Within this system, spatial and temporal patterns of hydrological change are manifest as changes in water depth, duration of inundation and duration of dry down, all of which are important ecological drivers (Gottlieb et al., 2006). Periphyton mats are specifically influenced by changes in water depth and duration of dry down. Mat inorganic content declines significantly in response to increasing water depth, resulting in a predominance of mats with high organic content in deeper areas and mats with high calcite content in shallower areas (Gottlieb et al., 2006; Gaiser et al., 2004). Under extended dry conditions, periphyton mats can become desiccated but have been shown to be capable of rapid recovery and growth upon re-wetting (Thomas et al., 2006; Gottlieb et al., 2006).

Because the Everglades is an extremely oligotrophic system in which phosphorus (P) is the main limiting nutrient (Noe et al., 2001), the rapid uptake and assimilation of $\mathrm{P}$ by periphyton mats is also of particular importance (McCormick and Scinto, 1999; Scinto and Reddy, 2003). Except under conditions of extreme and/or prolonged eutrophication, periphyton TP uptake efficiently removes TP from the water column, such that water TP concentration tends to remain low even with increased inputs of TP to the system (Gaiser et al., 2006). Periphyton mats can, however, show physiological, physical and compositional changes in response to low levels of TP enrichment within a matter of hours or days (McCormick and O'Dell, 1996; McCormick et al., 2001; Gaiser et al., 2005; Iwaniec et al., 2006; Munyon, in prep.) and therefore, elevated periphyton mat TP concentrations serve as a more reliable metric of TP inputs to the system than water column TP (Gaiser et al., 2005). 
In addition to rapidly removing TP from the water column, periphyton mats also exhibit marked responses to increases in TP, the most obvious being an anomalous decrease in overall mass and increase in organic content (Pan et al., 2000; McCormick et al., 2001; Gaiser et al., 2006). This response is also echoed in the diatom assemblage, which is dominated by species that exhibit a low tolerance for nutrient enrichment (McCormick et al., 1996; Cooper et al., 1999; Slate and Stevenson, 2007), but under enriched conditions, this assemblage shifts from an one of endemic mat species to one dominated by 'weedy' benthic taxa (Swift and Nicholas, 1987; Grimshaw et al., 1993; McCormick and O'Dell, 1996; Pan et al., 2000). The established relationship between periphytic diatom assemblage and TP has been used to develop diatom based calibration models to infer water (Slate and Stevenson, 2007), soil (Cooper et al., 1999) and periphyton mat (Gaiser et al., 2006) TP concentrations within the Everglades, as well as to indicate past environmental conditions and identify anthropogenically driven changes to the system using paleoecological techniques (Slate and Stevenson, 2000).

The aforementioned body of work has served to show that within the Everglades wetland system both hydrology and water quality (primarily phosphorus concentrations) are significant in determining the form and function of periphyton mats. It also highlights that pweriphyton mat diatom assemblages are particularly useful indicators of water quality.

Within the Caribbean and Central American region there exist karstic wetlands that are very similar to those found within the Everglades. These wetlands resemble the Everglades with respect to climate, geology, vegetation, water quality, and the presence of calcite-rich periphyton mats (Rejmánková, 2001; Rejmánková and Komárková, 2000; 
Novelo and Tavera, 2003; Novelo et al., 2007). The existence of such similar systems provides a venue for examining relationships between periphyton and environmental conditions in multiple tropical karstic wetlands, and facilitates a test of the validity of generalizing relationships observed in the Everglades to represent what may occur in tropical, freshwater karstic wetlands as a whole. Also, portions of these wetlands have been subjected to agricultural and industrial activities, which have led to changes in water quality and concomitant ecosystem degradation (Rejmánková and Komárková, 2005). Although the use of biological indicators would be valuable in the management of these wetlands, the pervasive lack of environmental and species data across much of the region precludes the development of site-specific diatom inference models.

The main objectives of this study therefore seek to (i) examine relationships between periphyton mat attributes and water quality in karstic wetland habitats in Belize, Mexico and Jamaica, compare these relationships to those found within similar Everglades wetland habitats and test the hypothesis that water depth and periphyton TP content are both drivers of periphyton biomass in tropical karstic wetland systems (Chapter II), (ii) provide a taxonomic inventory of the diatom species of periphyton mats from wetlands in Belize, Mexico, Jamaica (Chapter III) and (iv) examine and compare the relationship between periphyton mat TP concentrations and diatom assemblage at the Everglades and Caribbean locations and determine the feasibility of employing models relating diatom assemblage to water quality in the Everglades to similar systems within the wider Caribbean (Chapter IV). 


\section{LITERATURE CITED}

Azim, M. E. and T. Asaeda. 2005. Periphyton structure, diversity and colonization. Pages. 15-33. in M. E. Azim, M. C. J. Verdegem, A. A. van Dam, M. C. M. Beveridge. (editors). Periphyton: ecology, exploitation and management. CABI Publishing, Oxfordshire, UK.

Brock, T. D., 1970, Photosynthesis by algal epiphytes of Utricularia in Everglades National Park, Bulletin of Marine Science., 20. 952-956

Browder, J.A., Cottrell, D., Brown, M., Newman, M., Edwards, R., Yuska, J., Browder, M., Krakoski, J., 1982. Biomass and Primary Production of Microphytes and Macrophytes in Periphyton Habitats of the Southern Everglades. Report T-662, South Florida Research Center, Homestead, Florida.

Browder JA, PJ Gleason, DR Swift (1994) Periphyton in the Everglades: spatial variation, environmental correlates, and ecological implications. In: Davis SM, Ogden JC (eds) Everglades: The Ecosystem and its Restoration. St. Lucie Press, Delray Beach, Florida, pp 379-418

Cooper, S.R., Huvane, J., Vaithiyanathan, P., Richardson, C.J., 1999. Calibration of diatoms along a nutrient gradient in Florida Everglades Water Conservation Area-2A, USA. Journal of Paleolimnology 22, 413-437.

Donar CM, Condon KW, Gantar M, Gaiser EE (2004) A new technique for examining the physical structure of Everglades floating periphyton mat. Nova Hedwigia 78:107-19

Ewe, S.M.L., Gaiser, E.E., Childers, D.L., Rivera-Monroy, V.H., Iwaniec, D., Fourquerean, J., Twilley, R.R., 2006. Spatial and temporal patterns of aboveground net primary productivity (ANPP) in the Florida Coastal Everglades LTER (2001-2004). Hydrobiologia 569, 459-474.

Gaiser EE, Scinto LJ, Richards JH, Jayachandrana K, Childers DL, Trexler JC, Jones RD (2004) Phosphorus in periphyton mats provides the best metric for detecting low-level $\mathrm{P}$ enrichment in an oligotrophic wetland. Water Research 38:507-516 
Gaiser EE, Trexler JC, Richards JH, Childers DL, Lee D, Edwards AL, Scinto LJ, Jayachandran K, Noe GB, Jones RD (2005) Cascading ecological effects of low-level phosphorus enrichment in the Florida Everglades. Journal of Environmental Quality $34: 717-723$

Gaiser EE, Richards JH, Trexler JC, Jones RD, Childers DL (2006) Periphyton responses to eutrophication in the Florida Everglades: cross-system patterns of structural and compositional change. Limnology and Oceanograohy 51:617-630

Gaiser, E. E., La Hée, J. M., Tobias, F. A. C., Wachnicka, A. H. 2010. Mastogloia smithii var. lacustris Grun.: A structural engineer of calcareous mats in karstic subtropical wetlands. Proceedings of the Academy of Natural Sciences of Philadelphia (in press)

Gleason PJ, Spackman W (1974) Calcareous periphyton and water chemistry in the Everglades. In: Gleason PJ (ed.) Environments of South Florida: Past and Present, Memoir No. 2. Miami Geological Society, Coral Gables, Florida, pp 225-248

Goldsborough LG, Robinson GGC (1996) Pattern in wetlands. In: Stevenson RJ, Bothwell ML, Lowe RL (eds.) Algal Ecology in Freshwater Benthic Ecosystems. Academic Press, pp 77-117

Gottlieb AD, Richards JH, Gaiser EE (2006) Comparative study of periphyton community structure in long and short hydroperiod Everglades marshes. Hydrobiologia 569:195-207

Grimshaw HJ, Rosen M, Swift DR, Rodberg K, Noel JM (1993) Marsh phosphorus concentrations, phosphorus content and species composition of Everglades periphyton communities. Archiv für Hydrobiologie 128:257-276

Gunderson LH (1994) Vegetation of the Everglades: Determinants of community composition. In: Davis SM, Ogden JC (eds) Everglades: The Ecosystem and its Restoration. St. Lucie Press, Delray Beach, Florida, pp 323-340

Hagerthey, S. E., B. J. Bellinger, K. Wheeler, M. Gantar, and E. Gaiser. In Press.Everglades Periphyton: A Biogeochemical Perspective. Reviews in Environmental Science and Technology. 
Iwaniec DM, Childers DL, Rondeau D, Madden CJ, Saunders CJ (2006) Effects of hydrologic and water quality drivers on periphyton dynamics in the southern Everglades. Hydrobiologia 569:223-235

Liston SE, Newman S, Trexler JC (2008) Macroinvertebrate community response to eutrophication in an oligotrophic wetland: An in situ mesocosm experiment. Wetlands 28:686-694

Loveless, C.M. 1959. A study of the vegetation in the Florida Ever-glades. Ecology 40:19

McCormick PV, O’Dell MB (1996) Quantifying periphyton responses to phosphorus in the Florida Everglades: a synoptic-experimental approach Journal of the North American Benthological Society 15:450-468

McCormick PV, Rawlik PS, Lurding K, Smith EP, Sklar FH (1996) Periphyton-water quality relationships along a nutrient gradient in the northern Everglades. Journal of the North American Benthological Society 15: 433-449

McCormick PV, Stevenson RJ (1998) Periphyton as a tool for ecological assessment and management in the Florida Everglades. Journal of Phycology 34:726-733

McCormick, P.V. and Scinto, L.J., 1999. Influence of phosphorus loading on wetlands periphyton assemblages: A case study from the Everglades. In: Reddy, K.R., Editor, 1999. Phosphorus Biogeochemistry in Subtropical Ecosystems, CRC Press, Boca Raton, FL, pp. 301-319.

McCormick, P. V., M. B. O'Dell, R. B E. Shuford III, J. G. Backus, and W. C. Kennedy. 2001. Periphyton responses to experimental phosphorus enrichment in a subtropical wetland. Aquatic Botany 71:119-139.

Mitsch, W.J. \& Gosselink, J.G.; 2000, Wetlands, 3rd edition, John Wiley and Sons, NY Munyon, J.W., J.S. Schedlbauer, S.F. Oberbauer, E.E. Gaiser, and G. Starr. In preparation. Contrasting ecosystem productivity between a long- and short-hydroperiod marsh in the Florida Everglades. 
Neto, R., R.N. Mead, W.J. Louda, R. Jaffe. 2006. Organic biogeochemistry of detrital flocculent material (floc) in a subtropical, coastal wetland. Biogeochemistry , 77: 283304.

Noe, G. B., Childers, D. L. and Jones, R. D. 2001. Phosphorus biogeochemistry and the impact of phosphorus enrichment: Why is the Everglades so unique? Ecosystems 4: 603624.

Noe GB, Childers DL (2007) Phosphorus budgets in Everglades wetland ecosystems: the effects of hydrology and nutrient enrichment. Wetlands Ecology Management 15:189205

Novelo E, Tavera R, Ibarra C (2007) Bacillariophyceae from Karstic Wetlands in Mexico. Bibliotheca Diatomologica 54:1-136

Novelo E, Tavera R (2003) The role of periphyton in the regulation and supply of nutrients in a wetland at El Edén, Quintana Roo. In: Gómez-Pompa A, Allen MF, Fedick SL, Jiménez-Osornio JJ (eds.) The Lowland Maya Area. Three Millennia and the Human-Wildland Interface. Food Products Press, NY, pp 217-239

Pan, Y., Stevenson, R.J., Vaithiyanathan, P., Slate, J., Richardson, C.J., 2000. Changes in algal assemblages along observed and experimental phosphorus gradients in a subtropical wetland, USA. Freshwater Biol. 44, 339-353.

Raschke, R.L., 1993. Diatom (Bacillariophyta) community response to phosphorus in the Everglades National Park, USA. Phycologia 32, 48-58.

Rejmánková E, Komárková J (2000) Function of cyanobacterial mats in phosphoruslimited tropical wetlands. Hydrobiologia 431:135-153

Rejmánková E (2001) Effect of experimental phosphorus enrichment on oligotrophic tropical marshes in Belize, Central America. Plant Soil 236:33-53

Rejmánková, E., J. Komárek, and J. Komárková. 2004. Cyanobacteria - a neglected component of biodiversity: patterns of species diversity in inland marshes of northern Belize (Central America). Diversity and Distributions 10:189-99. 
Rejmánková, E. and J. Komárková. 2005. Response of cyanobacterial mats to nutrient and salinity changes. Aquatic Botany 83:87-107.

Scinto LJ, Reddy KR (2003) Biotic and abiotic uptake of phosphorus by periphyton in a subtropical freshwater wetland. Aquatic Botany 77:203-222

Slate, J.E., and R.J. Stevenson. 2000. Recent and abrupt environmental change in the Florida Everglades indicated from siliceous microfossils. Wetlands 20:346-356.

Slate JE, Stevenson RJ (2007) The diatom flora of phosphorus enriched and unenriched sites in an Everglades marsh. Diatom Research 22:355-386

Stal LJ (2000) Cyanobacterial mats and stromatolites. In: Whitton BA, Potts M (eds) The Ecology of Cyanobacteria: Their Diversity in Time and Space. Kluwer Academic Publishers, Dordrecht, The Netherlands, pp 61-120

Swift DR, Nicholas RB (1987) Periphyton and water quality relationships in the Everglades Water Conservation Areas, 1978-1982. Technical Publication 872, South Florida Water Management District, West Palm Beach, Florida

Thomas S, Gaiser EE, Gantar M, Scinto L, Jones RD (2006) Quantifying the response of calcareous periphyton crusts to rehydration: a microcosm study (Florida Everglades). Aquatic Botany 84:317-323

Van Meter-Kasanof N (1973) Ecology of the microalgae of the Florida Everglades. Part I. Environment and some aspects of freshwater periphyton, 1959 to 1963. Nova Hedwigia 24:619-664

Willard, D. A., Holmes, C. W. \& Weimer, L. M. 2001. The Florida Everglades Ecosystem: Climatic and Anthropogenic Impacts over the Last Two Millennia. Paleoecology of Southern Florida.B. R. Wardlaw, ed. Bulletin of American Paleontology $361,41-55$

Williams AJ, Trexler JC (2006) A preliminary analysis of the correlation of food-web characteristics with hydrology and nutrient gradients in the southern Everglades. Hydrobiologia 569:493-504 
Wilson, S. U. (1974). Metabolism and biology of a blue-green algal mat. 104 pp. M. S. Thesis, University of Miami, Coral Gables, Florida.

Winkler, M. G., Sanford, P. R., and Kaplan, S. W. (2001). Hydrology, vegetation, and climate change in the southern Everglades during the Holocene. In Paleoecology of Southern Florida.B. R. Wardlaw, ed. Bulletin of American Paleontology. 361: 57-99.

Wood EJF, Maynard NG (1974) Ecology of the microalgae of the Florida Everglades. In Gleason PJ (ed) Environments of South Florida: Past and Present, Memoir No. 2.Miami Geological Society, Coral Gables, Florida, pp 123-145 


\title{
CHAPTER II
}

Phosphorus and hydrology as drivers of periphyton mat biomass in the Everglades and three tropical karstic wetlands

\begin{abstract}
Hydrology and water quality greatly influence periphyton mat production in the Everglades, where increases in water depth and periphyton mat total phosphorus (TP) concentrations result in an anomalous decline in periphyton mat biomass. This study was conducted to determine whether these responses are unique to the Everglades or are symptomatic of tropical karstic wetland systems within the northern Caribbean region. Periphyton mat samples and water quality data were collected at sites in shallow, marlbased wetlands in Belize, Mexico and Jamaica. These data were compared to a larger dataset collected from comparable sites within the Everglades National Park. Periphyton mat biomass was negatively correlated with TP and water depth at Everglades $(p<0.0001)$ and Caribbean $(\mathrm{p}<0.05)$ locations. Percent organic content was positively correlated with TP within the Everglades $\left(\mathrm{R}^{2}=0.44, \mathrm{p}<0.0001\right)$, and water depth at both Everglades $\left(\mathrm{R}^{2}=0.23, \mathrm{p}<0.0001\right)$ and Caribbean locations $\left(\mathrm{R}^{2}=0.35, \mathrm{p}<0.001\right)$. Principle Component Analysis showed that at Everglades and Caribbean locations, periphyton mats with higher TP were found at deeper sites and had lower biomass and higher organic content. These results strongly suggest that water depth and, to a greater extent, periphyton mat $\mathrm{TP}$, are both drivers of periphyton mat dynamics in tropical karstic wetland systems.
\end{abstract}




\section{INTRODUCTION}

Karstic wetlands occur throughout the world and collectively comprise a distinctive set of habitats that exist as an expanse of shallow marsh or swampland overlying limestone bedrock. While the constituent flora and fauna may vary considerably among these wetlands, one biological component that tends to be a common feature is the cyanobacteria-dominated communities that occur as thick, multilayered calcium carbonate (calcite)-rich mats (Stal, 2000). As is the case with periphyton mats in other aquatic systems, these mats serve multiple ecological roles and are greatly influenced by changes in environmental conditions (McCormick and Scinto, 1999; Gaiser, 2009). The relationships between periphyton mat ecology and various environmental conditions have been most intensely studied within the Everglades wetland system in southern Florida, U.S.A. This expansive karstic wetland system has been subjected to the effects of decades of anthropogenic alterations, prompting investigations of the use of periphyton mats as indicators of environmental stress and recovery (McCormick and Stevenson1998; Noe and Childers, 2007; Gaiser et al., 2004).

Throughout much of the Everglades, periphyton occurs as epipelic, epiphytic or free floating masses of thick mat, the various forms of which may be distinguished primarily by their dominant taxonomic group and the relative contribution of the inorganic (calcite) component to overall periphyton mat mass (Van-Meter Kasanof, 1973; Browder, 1982). Mats range from those dominated by filamentous cyanobacteria, (primarily Schizothrix spp. and Scytonema spp.) and diatoms, with a major calcite component, to those dominated by desmids and filamentous green algae, with a minor 
calcite component. The various photosynthetic components of these mats tend to display a high microbial taxonomic diversity and the complement of taxa forming the dominant group varies considerably depending on mat type (Van-Meter Kasanof, 1973; Swift and Nicholas, 1987; Slate and Stevenson, 2007; Gaiser, 2009).

Calcitic mats can constitute the most productive biological component of Everglades wetlands, displaying cross-system biomass values which, in many areas, exceed that of standing macrophytic vegetation (Ewe et al., 2006; Gaiser, 2009; Richardson, 2009). As the base of the algal food web, the edible portions of these mats are a significant food source for microinvertebrates, macroinvertebrates and fish, and their structural architecture provides microhabitats for these organisms, many of which use the moist mat layers as a refuge during dry periods (Williams and Trexler, 2006; Liston et al., 2008). Periphyton mats are also important biogeochemical regulators within the Everglades wetland system, where they significantly influence diurnal and annual changes in water chemistry and facilitate the deposition of calcite, which is the dominant soil type in shallow, short-hydroperiod marshes (i.e. marshes which remain flooded for 3 to 8 months out of the year) (McCormick and Scinto, 1999; Scinto and Reddy, 2003).

The results of multiple studies conducted across a variety of Everglades habitats have shown that periphyton mat form and function varies predictably in relation to hydroperiod and water chemistry (McCormick and O'Dell, 1996; Childers et al., 2001; Noe et al., 2002; Gaiser et al., 2004; Iwaniec et al., 2006). Many of these studies have also revealed specific relationships and processes, the controlling mechanisms of which are still not fully understood. 
Both water depth and the period of inundation change across the wetland landscape in response to topographical variability. The inorganic content of periphyton mats, which is dominated by calcite, declines significantly as water depth increases, resulting in a predominance of mats with high organic content in deeper areas and mats with high calcite content in shallower areas (Gottlieb et al., 2006; Gaiser et al., 2004). Under extended dry conditions, periphyton mats can become desiccated, but have been shown to be capable of rapid recovery and growth upon re-wetting (Thomas et al., 2006; Gottlieb et al., 2006). A paradoxical negative relationship between periphyton mat total phosphorus (TP) concentration and biomass has also been identified. As periphyton mat $\mathrm{TP}$ concentrations exceed $250 \mu \mathrm{g} \mathrm{g}^{-1}$ dry weight, mats begin to display significantly reduced biomass and may disintegrate entirely after continued exposure to elevated phosphorus levels (Pan et al., 2000; McCormick et al., 2001). This response to enrichment is in opposition to the general pattern observed in aquatic systems, where an increase in limiting nutrients results in a concomitant increase in algal growth rates and total biomass (McCormick et al., 2001). This body of work suggests that both hydrology and water quality (primarily phosphorus levels) are significant in determining the form and function of periphyton mats within the Everglades wetland system. However, it is currently unknown whether the importance of these factors as drivers of periphyton mat ecology is unique to the Everglades, or if the observed patterns are characteristic of tropical, freshwater karstic wetlands in general.

Recent studies conducted in karstic wetlands within Mexico, Belize and Jamaica have identified areas with similar climate, geology and vegetation that support habitats and periphyton mat communities comparable to those found in the Everglades 
(Rejmánková, 2001; Rejmánková and Komárková, 2000; Novelo and Tavera, 2003; Novelo et al., 2007). The existence of such similar systems provides a venue for examining relationships between periphyton mats and environmental conditions in multiple tropical karstic wetlands and facilitates a test of the validity of generalizing relationships observed in the Everglades to represent what may occur in tropical, freshwater karstic wetlands. The main objectives of this study therefore seek to (i) examine relationships between periphyton mat attributes and water quality in karstic wetland habitats in Belize, Mexico and Jamaica, (ii) compare these relationships to those found within similar Everglades wetland habitats and (iii) test the hypothesis that water depth and periphyton mat TP content are both drivers of periphyton mat biomass in tropical karstic wetland systems.

\section{SITE DESCRIPTION}

Sampling was conducted in three wetland systems, similar with respect to geology, climate, hydrology and vegetation and located within the northern Caribbean Basin: the Sian Ka'an Biosphere Reserve (and areas to the south) in Quintana Roo, Mexico; the New River Lagoon in Orange Walk, Belize; and the Broad River in the Black River Morass, St. Elizabeth, Jamaica (Figure 2-1, Table 2-1).

The Sian Ka'an Biosphere Reserve and the wetlands extending beyond its boundary to the south, encompass a $6500 \mathrm{~km}^{2}$ area along the south eastern coast of the Yucatan Peninsula in Quintana Roo, Mexico (Cairns et al., 2005). The Yucatan peninsula is an uplifted marine platform which extends from the greater Yucatan platform and 
serves as a divide between the Gulf of Mexico and the Caribbean Sea. The geological formation is a 2 to $3 \mathrm{~km}$ thick sequence dominated by limestone, with intermittent layers of dolomite, anhydrite and gypsum (Weidie, 1985). The karstic wetland marshes located within the Yucatan region are dominated by low phosphorus, inland freshwater, marlbased habitats and coastal mesohaline habitats. The most common freshwater macrophytic species include Cladium jamaicense (sawgrass), Eleocharis spp. (spikerush) and Typha domingensis (southern cattail), each of which tends to become dominant at low, intermediate and high water depths, respectively (Rejmánková et al., 1996). Dwarf populations of Rhizophora mangle (red mangrove) become more abundant as salinity levels increase, and form the dominant tree species in the coastal brackish water marshes. Calcitic periphyton mats are abundant in both freshwater and brackish water habitats with marl substrates (Rejmánková et al., 1996). Inland sampling sites were confined to freshwater, Eleocharis spp. marshes, and closer to the coast, brackish water sites dominated by dwarf Rhizophora mangle were sampled.

The New River Lagoon, located in the district of Orange Walk in northern Belize, is an approximately $23 \mathrm{~km}$ long and $750 \mathrm{~m}$ wide stretch of the New River, which is the longest river contained entirely within Belize (Meerman, 2006). The area lies just to the southeast of the basal portion of the Yucatan peninsula and exhibits geological features similar to the adjacent landmass (Weidie, 1985). The New River Lagoon is flanked by extensive marshes dominated mainly by Cladium jamaicense, Eleocharis cellulosa and Eleocharis interstincta, with intermittent deeper pools supporting dense assemblages of Nymphea ampla (dotleaf waterlilly). Sampling sites in this area were again confined to Eleocharis spp. marshes adjacent to the lagoon. 
The Black River Morass encompasses the largest wetland and river system within the Greater and Lesser Antillean archipelago (Davis et al., 1998; Massa and HaynesSutton, 1998). It lies within the Black River Basin, which occupies an area of approximately $1,488 \mathrm{~km}^{2}$ in the south-western region of Jamaica. The area is divided into two main sections: the Upper and Lower Morass. The Upper Morass is approximately $97 \mathrm{~km}^{2}$ (Cronberg, 1983) and is composed of a mass of swampy lowlands with limestone bedrock covered by peat deposits. The Lower Morass which is approximately $57 \mathrm{~km}^{2}$ (Enell, 1984), exists as an area of down-faulted, poorly karstified limestone, overlain by a relatively thin clay and peat sequence. Inland marsh areas display mixed vegetation dominated by Cladium jamaicense and Eleocharis spp., with large stands of Typha domingensis being present in some areas (Azan and Webber, 2007). Closer to the coast, assemblages dominated by Rhizophora mangle are prevalent and these trees can also be found bordering the main waterways as they meander through the wetland system. Sampling sites were located within Cladium jamaicense and Eleocharis spp. marshes bordering the Broad River, a major tributary of the Black River.

Data collected from these wetlands were compared to a larger dataset collected from a total of 110 sites within the Everglades National Park, in southern Florida, U.S.A (Figure 2-1, Table 2-1). The Everglades freshwater wetland system encompasses an area of approximately $5,000 \mathrm{~km}^{2}$, and is one of the largest contiguous wetland systems in North America (McCormick et al., 1998; Childers et al., 2001). The system is geologically young, having formed less than 5,000 years ago as a result of extended hydroperiod regimes that encouraged the deposition of peat and marl in the midst of a limestone depression (Gleason and Stone, 1994). The vegetation structure of the 
Everglades marsh habitats is similar to that of the previously described sites, with Cladium jamaicense and Eleocharis spp. marshes being common and Nymphaea odorata (American white waterlilly), Nymphaea aquatica (water shield) and Nuphar advena (spatterdock) characterizing deeper slough areas (Gunderson, 1994; Richardson, 2009). For this study, the data utilized were drawn from a large dataset derived from multiple seasonal sampling events conducted throughout the Everglades as part of the Periphyton component of the Comprehensive Everglades Restoration Plan (see CERP, 2005; Gaiser, 2009).

\section{METHODS}

Each of the Caribbean study locations was visited on two occasions; once during a wet period and once during a dry period. Due to abnormal seasonal rainfall patterns during the course of the study, wet and dry periods did not necessarily coincide with the typical regional wet and dry seasons. "Wet" and "dry" designations were therefore applied based on rainfall levels at each location during the sampling period, relative to typical wet and dry seasonal rainfall levels. The Everglades samples were collected during October to December, 2005 (wet period) and September to December, 2006 (dry period) as part of the periphyton mat component of the CERP seasonal sampling regime. The sites in Mexico were visited in December 2006 (wet period) and March 2008 (dry period), the Belize sites in May 2007 (dry period) and November 2007 (wet period), and the Jamaica sites in May 2008 (dry period). Samples were collected during the wet period at Jamaica sites, however, these were qualitative grab samples, which precluded any 
quantitative analyses and so were not included in this study. Efforts were made to conduct sampling at as many sites as possible within each location, however during dry periods the number of sites sampled varied according to the ability to locate sites that sustained water levels greater than $5 \mathrm{~cm}$. During wet periods, sampling efforts were contingent on the ability to gain access to sites and were then limited to sites that did not exceed water depths of $1 \mathrm{~m}$.

At each location, sampling sites were limited to marshes dominated by Eleocharis spp., however, at some sites Nymphaea spp., Cladium jamaicense and dwarf Rhizophora mangle were also present. At each site, GPS coordinates were recorded and sampling was then conducted using a $1-\mathrm{m}^{2}$ throw trap to delineate a $1-\mathrm{m}^{2}$ area which was treated as a sample plot (Kushlan, 1981). Four plots were sampled at each site. For each plot a photograph was first taken of the surface view of the quadrat and then soil type (e.g., marl, peat, clay, sand), periphyton mat type (e.g., benthic, floating, epiphytic) and water depth were recorded.

Periphyton mat cover was recorded as separate in situ estimates of the percent of the plot covered by benthic, epiphytic and floating periphyton mat. All periphyton material was then cleared from the plot by hand, placed onto a bar seine net and coarsely sorted to remove animals and any attached marl. Live submerged aquatic vegetation (SAV) often becomes intricately incorporated into the periphyton mat structure, especially in situations where a very close association has developed between the algal mat and its plant substrate (Browder et al., 1994). This is most often seen in mats associated with species such as Utricularia purpurea (floating mats), Eleocharis cellulosa, Cladium jamaicensis (epiphytic mats) and Chara sp. (benthic mats). To 
account for these associations two estimates of periphyton mat biovolume were recorded in the field. For the first, all plant material was removed from the collected periphyton mats and "periphyton only" material was measured using a perforated 2,000 ml graduated cylinder that allowed water to drain, permitting periphyton mat biovolume to be recorded. Next, the removed plant material was measured in the graduated cylinder, and this biovolume was added to the first to produce a periphyton $+\mathrm{SAV}$ total biovolume. The first of these estimates of biomass is henceforth referred to as periphyton mat biovolume (BV), while the latter is considered total periphyton mat biovolume (TBV). A subsample of $120 \mathrm{ml}$ was removed from the "periphyton only" mat material, placed in a sterile sample bag and stored in a cooler with ice for transport to the lab. When no observable calcitic periphyton mats were present, epipelon was sampled from the benthos and epiphytic films were scraped from any macrophytes present.

In the laboratory, each sample was weighed to obtain a wet weight, and then transferred to a clean $500-\mathrm{ml}$ beaker to which an additional $20 \mathrm{ml}$ of distilled water was added to facilitate homogenizing. From the homogenized total volume, a 50-ml subsample was poured into a pre-weighed aluminum pan, dried in an oven at $80^{\circ} \mathrm{C}$ for 48 hrs and later removed and weighed to estimate periphyton mat dry mass (DM). The dried sample was placed in a muffle furnace at $500^{\circ} \mathrm{C}$ for $3 \mathrm{hrs}$ and again weighed to produce an ash weight, which is the inorganic portion of the sample. The difference between these two values was calculated as the ash-free dry mass (AFDM), which represents the organic portion of the periphyton mat sample. Another 50-ml subsample was removed from the homogenized total sample, poured into a labeled 120-ml sample cup and placed in a drying oven at $80^{\circ} \mathrm{C}$ until completely dry. The dried contents were then ground 
using a mortar and pestle and analyzed for TP following the methods of Solórzano and Sharp (1980). A final 1-ml subsample was removed and filtered through a GFF filter, which was later analyzed for chlorophyll $a$, following acetone extraction (Welschmeyer, 1994).

A total of 9 variables were recorded and analyzed: periphyton mat + SAV total biovolume (TBV $\mathrm{ml} \mathrm{m}^{-2}$ ), periphyton mat biovolume $\left(\mathrm{BV} \mathrm{ml} \mathrm{m}^{-2}\right)$, periphyton mat dry mass $\left(\mathrm{DM} \mathrm{g} \mathrm{m}^{-2}\right)$, periphyton mat ash-free dry mass (AFDM $\mathrm{g} \mathrm{m}^{-2}$ ), periphyton mat percent organic content $(\mathrm{ORG}=((\mathrm{AFDM} / \mathrm{DM}) \times 100)$, periphyton mat total phosphorus (TP $\mu \mathrm{g} \mathrm{P} \mathrm{g}^{-1}$ dry mass), periphyton mat chlorophyll $a$ biomass $\left(\mathrm{CH} \mu \mathrm{g} \mathrm{m}^{-2}\right)$, periphyton mat chlorophyll $a$ concentration ( $\mathrm{CHC} \mu \mathrm{g} \mathrm{g}^{-1}$ dry mass) and water depth (WD cm). Prior to statistical analysis, each dataset was first transformed to meet the assumption of normality: TBV, BV and WD were square root transformed, DM and AFDM were $4^{\text {th }}$ root transformed, ORG, TP, $\mathrm{CH}$ and $\mathrm{CHC}$ were $\log 10$ transformed, with $\log 10(\mathrm{x}+1)$ being used for $\mathrm{CH}$ and $\mathrm{CHC}$ values to ensure log values were positive.

Statistical analyses were conducted to determine (i) differences among locations, (ii) differences between wet and dry periods, and (iii) relationships between and among measured variables. For these analyses, five sets of data were used: Everglades samples, Belize samples, Mexico samples, Jamaica samples and a composite of all the Belize, Mexico and Jamaica sites, collectively referred to as the Caribbean samples. Differences among locations were analyzed using analysis of variance (ANOVA) followed by Tukey's test (analyses were done using PASW Statistics 18). The results reported for the analyses of differences among sites, therefore, indicate which location (if any) was significantly different to all other locations. Differences between sampling occasions for 
each location (wet vs dry) were analyzed using Student's T-test. Regression analysis and Pearson's correlation (done using the statistical program R) were used to test for significant linear relationships between pairs of variables. PCORD 5 (McCune and Grace, 2002) was used to perform a Principal Component Analysis (PCA) examining differences among sites for all locations based on the 9 measured variables. The PCA was performed twice, first using Everglades sites only and second using Caribbean sites only. These two results allowed comparisons to be made between patterns in the Everglades and the Caribbean locations. Joint plots were used to show the direction and strength of the relationships among these measured variables.

\section{RESULTS}

\section{$\underline{\text { Site comparisons }}$}

Habitat characteristics among the sampled locations overlapped, with most sites being dominated by Eleocharis spp. growing in shallow $(<1 \mathrm{~m})$ marl based soils, inundated by circumneutral waters. Among all four locations, average $\mathrm{pH}$ ranged from 7.2 to 9.2 and average conductivity ranged from 441.8 to $15,047.7 \mu \mathrm{S} \mathrm{cm}^{-1}$ (Table 2-2). Some sampling sites within the Mexico location (Mahahual and Marisma) were closer to the coast and supported a macrophytic assemblage dominated by Rhizophora mangle and Eleocharis spp. At these sites average $\mathrm{pH}$ and conductivity levels were greater than all other sites (Table 2-2), which is a result of the influx of brackish-water at these sites. During the dry period sampling period at the Belize location, the interior marsh areas were completely dry and inaccessible. Sampling was therefore limited to Eleocharis spp. 
marshes bordering the New River Lagoon, where, prior to the dry season, lagoonal waters with elevated TP would have advanced into these peripheral marshes.

Water depth levels at sampling sites ranged from 5 to $105 \mathrm{~cm}$ among the four locations. Belize sites had a significantly greater mean water depth than Mexico sites during the wet period $(\mathrm{p}=0.025)$ and Jamaica sites had a significantly lower mean water depth than the Everglades sites during the dry period $(p=0.001)$ (Figure 2-2a).

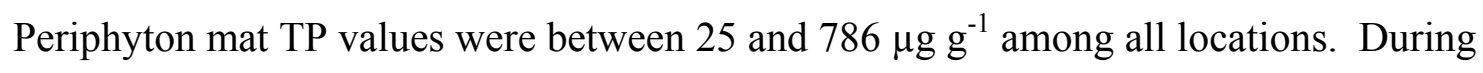
the dry period, the Belize location had mats with a significantly higher mean TP compared to Mexico and the Everglades ( $\mathrm{p}=0.018$ and $\mathrm{p}<0.0001$ respectively) and during the wet period Belize periphyton mat TP concentrations were significantly higher than at the Everglades location $(p=0.036)$ (Figure 2-2b).

TBV and BV ranged from 0 to $13,933 \mathrm{ml} \mathrm{m}^{-2}$ and 0 to $11,000 \mathrm{ml} \mathrm{m}^{-2}$ respectively, while mat DM and AFDM ranged from 0 to $2,079 \mathrm{~g} \mathrm{~m}^{-2}$ and 0 to $590 \mathrm{~g} \mathrm{~m}^{-2}$ respectively. Belize had significantly lower TBV and BV than Mexico and Everglades locations $(\mathrm{p}<$ $0.001)$ and significantly lower mean DM and AFDM when compared to all locations ( $p<$ 0.022 ), with the disparity being most pronounced during the dry period (Figure $2-2 \mathrm{c}, \mathrm{d}, \mathrm{e}$ and f).

Periphyton mat ORG ranged from 9.3 to $89.9 \%$ among all locations, with no significant differences among the locations (Figure 2-2g). $\mathrm{CH}$ biomass and $\mathrm{CHC}$ ranged from 0 to $362,088 \mu \mathrm{g} \mathrm{m}^{-2}$ and 0 to $1,217 \mu \mathrm{g} \mathrm{g}^{-1}$ respectively. Belize showed significantly lower values for $\mathrm{CH}$ compared to all other locations, $(\mathrm{p}<0.0001)$ during both wet and dry periods. $\mathrm{CHC}$ was lower at the Belize location than at the Everglades $(\mathrm{p}<0.0001)$ and Mexico location $(\mathrm{p}=0.007)$, but only during the wet period (Figure $2-2 \mathrm{~h}$ and $\mathrm{i}$ ). 


\section{Wet period to dry period comparisons}

Across all locations, water depth showed temporal variation, having greater values during the wet periods than during the dry periods, with the difference being significant for Everglades $(\mathrm{p}=0.001)$ and Belize $(\mathrm{p}<0.0001)$ (Figure 2-2a). Periphyton mat TP concentration showed no significant difference between wet and dry periods at any location (Figure 2-2b).

TBV, BV and DM measures showed no differences between wet and dry periods at any location. However, Belize AFDM was higher during the wet period $(p=0.01)$ (Figure 2-2c, d, e, f).

Periphyton mat ORG was higher during the wet period for Belize $(\mathrm{p}=0.002)$, but no significant differences were seen between periods for the Everglades and Mexico (Figure 2-2g). CH was only different between wet and dry periods for Belize, where values were greater $(\mathrm{p}=0.002)$ during the wet period (Figure $2-2 \mathrm{~h})$. CHC was consistently higher during the dry period across all locations, with the difference being significant at the Belize location $(\mathrm{p}<0.0001)$ (Figure 2-2i).

\section{$\underline{\text { Relationships between all variables and water depth }}$}

TBV, BV, DM, AFDM and $\mathrm{CH}$ all tended to decline in relation to water depth (Figure 2-3a, b, c, d, e), and while the negative relationships were all significant for the Everglades $(\mathrm{p}<0.0001)$, only BV and CH showed a significant trend for Caribbean sites $(\mathrm{p}=0.037$ and $\mathrm{p}=0.023)$. The relationship between $\mathrm{CHC}$ and water depth differed between the Everglades and the Caribbean sites (Figure 2-3f), with the former showing a significant positive relationship $\left(\mathrm{R}^{2}=0.35, \mathrm{p}<0.0001\right)$ and the latter showing a significant 
negative relationship $\left(\mathrm{R}^{2}=0.34, \mathrm{p}<0.001\right)$. Periphyton mat $\mathrm{ORG}$ showed a strong and significant positive relationship with water depth for both Everglades $\left(\mathrm{R}^{2}=0.23\right.$, $\mathrm{p}<0.0001)$ and Caribbean sites $\left(\mathrm{R}^{2}=0.35, \mathrm{p}<0.001\right)$ (Figure 2-3g).

$\underline{\text { Relationships between all variables and TP }}$

Periphyton mat biomass, measured as TBV, BV, DM, AFDM and CH biomass showed a strong and significant negative relationship with TP at both Everglades $(\mathrm{p}<0.0001)$ and Caribbean $(\mathrm{p}<0.01)$ sites (Figure 2-4a, b, c, d, e). Periphyton mat ORG tended to increase with TP at both Everglades and Caribbean sites, but the relationship was only significant for the Everglades $\left(\mathrm{R}^{2}=0.44, \mathrm{p}<0.0001\right)$ (Figure 2-4f). CHC also increased with TP, and this relationship was significant at both Everglades $\left(\mathrm{R}^{2}=0.60\right.$, $\mathrm{p}<0.0001)$ and Caribbean sites $\left(\mathrm{R}^{2}=0.18, \mathrm{p}=0.009\right)$ (Figure $2-4 \mathrm{~g}$ ).

There was a significant positive relationship between water depth and TP for the Everglades $\left(\mathrm{R}^{2}=0.18, \mathrm{p}<0.0001\right)$, however this pattern was not seen for the Caribbean sites (Figure 2-4h).

\section{$\underline{\text { Relationships among all variables }}$}

For the Everglades PCA (Figure 2-5a), axes 1, 2 and 3 explained 91.2\% of the variation $(73.3 \%, 11.0 \%$ and $6.8 \%$ respectively). TBV, BV, DM, AFDM and $\mathrm{CH}$ were all strongly positively correlated with axis $1\left(\mathrm{R}^{2}=0.74, \mathrm{R}^{2}=0.89, \mathrm{R}^{2}=0.97, \mathrm{R}^{2}=0.94, \mathrm{R}^{2}\right.$ $=0.68$, respectively; $\mathrm{p}<0.0001$ ), while $\mathrm{CHC}, \mathrm{ORG}$, mat TP and water depth were negatively correlated with this axis $\left(\mathrm{R}^{2}=0.74, \mathrm{R}^{2}=0.62, \mathrm{R}^{2}=0.63, \mathrm{R}^{2}=0.39\right.$, respectively; $\mathrm{p}<0.0001)$. This suggests that periphyton mats with higher TP concentrations tended to 
have lower biomass, higher ORG and were found at deeper sites, while mats with lower TP concentrations tended to have higher biomass, lower ORG and were found at shallower sites. Water depth also showed a positive correlation with axis $3\left(\mathrm{R}^{2}=0.42\right.$, $\mathrm{p}<0.0001$ ), possibly reflecting the difference between sites sampled during the wet period and those sampled during the dry period.

For the Caribbean PCA (Figure 2-5b), axes 1, 2 and 3 explained $92.0 \%$ of the variation $(57.9 \%, 21.4 \%$ and $12.7 \%$ respectively). TBV, BV, DM, AFDM and $\mathrm{CH}$ were all strongly positively correlated with axis $1\left(\mathrm{R}^{2}=0.93, \mathrm{R}^{2}=0.94, \mathrm{R}^{2}=0.95, \mathrm{R}^{2}=0.92, \mathrm{R}^{2}\right.$ $=0.66$, respectively; $\mathrm{p}<0.0001)$, while mat $T P$ was negatively correlated with this axis $\left(\mathrm{R}^{2}\right.$ $=0.56 ; \mathrm{p}<0.0001)$. This again suggests that as in the Everglades, sites that displayed higher mat TP concentrations also had mats of lower biomass. Unlike the Everglades PCA, however, Caribbean $\mathrm{CHC}$ and water depth showed positive and negative correlations with axis 2 respectively $\left(\mathrm{R}^{2}=0.79, \mathrm{R}^{2}=0.69 ; \mathrm{p}<0.0001\right)$. This reflects the negative relationship between these two variables, in which deeper sites tended to have periphyton mats with lower CHC. Periphyton mat ORG alone was correlated with axis 3 $\left(\mathrm{R}^{2}=0.64 ; \mathrm{p}<0.0001\right)$, which likely reflects the influence of both water depth and mat TP.

\section{DISCUSSION}

Within the Everglades wetland system, periphyton mats are noted for their large standing crop and productivity (Goldsborough and Robinson, 1996; Ewe et al., 2006; Gaiser, 2009), as well as their response to changes in hydrology and water quality (Gottlieb et al., 2006; McCormick et al., 2001; Gaiser et al., 2005 and 2006). In this 
study, very strong significant relationships between water depth, phosphorus and periphyton mat biomass were observed within the Everglades wetland system and these trends, though less robust, were also evident at karstic wetland sites within three widely separated Caribbean locations.

Water depth effects on periphyton mats were evaluated by examining a range of sites that showed natural spatial variation in water depth, as well as temporal differences associated with the wet and dry periods. Within the Everglades, periphyton mat mass, measured as TBV (which includes organic and inorganic matter and associated aquatic vegetation), BV and DM (which include only organic and inorganic matter) and AFDM and $\mathrm{CH}$ (which include only organic matter), decreased as water depth increased. However, the $\mathrm{ORG}$ and $\mathrm{CHC}$ showed the opposite trend of increasing in response to increased water depth. Thus, while absolute values for both organic and inorganic mass decreased with increasing water depth, the relative contributions of these components to overall mat biomass did not respond in the same way. As water depth increased, the proportion of periphyton mat algal content increased, while there was a concomitant decrease in the percent of inorganic mass.

Considering that the ORG within these mats was very high in shallower sites, accounting for up to $\sim 91 \%$ of total mat biomass, the significant reduction in inorganic mass with increased water depth is clearly responsible for the reduction in total periphyton mat biomass with increased water depth. This result demonstrates a pattern that has been described in other studies. Gottlieb and others (2006), in a study comparing periphyton mats from long and short-hydroperiod marshes within the Everglades, found that although short hydroperiod sites had, on average, greater than 5 times the biomass 
found at long-hydroperiod sites, the ORG in short-hydroperiod marsh periphyton mats averaged only $37 \%$, while that of long-hydroperiod marsh periphyton mats averaged $53 \%$. Differences among sites may arise because in short-hydroperiod marshes periphyton mats grow in close association with the marl substrate and incorporate more calcium carbonate into its biomass than the floating periphyton mats common in longhydroperiod areas. The reduction of mat biomass as water depth increases can also be a result of associated changes in water chemistry. In deeper, peat-based areas, there is generally a reduction in ambient $\mathrm{pH}$ levels and calcite saturation levels, both of which influence calcium carbonate deposition within periphyton mats (Gleason and Spackman, 1974; McCormick and Scinto, 1999; Pentecost and Whitton, 2000). The inhibition of calcium carbonate precipitation results in the development of floating and epiphytic periphyton mats with reduced calcite content, reduced total biomass, and elevated ORG. In more shallow habitats, ambient conditions support calcium carbonate deposition, lending to the production of mostly benthic and epiphytic periphyton mats with a high calcite content, high total biomass and low ORG.

The lower $\mathrm{pH}$ levels associated with deep-water habitats could have an additional effect on periphyton mats. Calcium carbonate has been shown to bind phosphorus, making it unavailable for biological uptake (Otsuki and Wetzel, 1972). However, as $\mathrm{pH}$ levels decline, phosphorus becomes liberated from calcium carbonate and remains available within the water column (McCormick and Scinto, 1999). Under these conditions, periphyton mats rapidly take up and utilize available phosphorus, and this leads to increased mat TP concentrations (Grimshaw et al., 1993; Thomas et al., 2002). 
This effectively explains the strong positive relationship between water depth and periphyton TP that was observed at the Everglades sites.

Analysis of the data from the Caribbean karstic wetland sites also showed a decrease in periphyton mat biomass and increase in organic matter as water depth increased. Unlike the Everglades results, however, these relationships were not always significant. The reduced strength of these relationships is most likely a result of some of the Belize sample sites, which were located along the border of a river lagoon and did not extend all the way in to the adjacent Eleocharis spp. marshes (which were completely dry and inaccessible during the dry period visit). These Belize sample sites were therefore taken from typical long-hydroperiod marshes; however, this was not reflected by their water depths, which were at the time fairly low as a result of severe drought. This led to the collection of non-calcitic, low biovolume, unconsolidated, detrital samples, with elevated TP content from sites of low to moderate water depth. If this interpretation is correct, their inclusion would have reduced the strength of the relationships between water depth and biovolume and mat TP content across Caribbean sites.

The Belize wet-period samples also influenced the relationship between water depth and CHC. Many of these samples had high ORG consisting of dead organic matter, but very little live algae. This resulted in a significant positive linear relationship between water depth and periphyton mat ORG, but a negative correlation between water depth and CHC. It is likely that if the number of sites sampled was greater, these few samples would have had less of an impact on the overall pattern of the data.

The influence of TP on periphyton mats has been well documented within the Everglades. Multiple studies have been conducted in the Water Conservation Areas in 
the northern part of the Everglades, where inflows of nutrient enriched water drained from agricultural areas to the north have created a north to south water quality gradient (Smith and McCormick, 1999; McCormick and Laing, 2003). McCormick et al. (1998) compared water quality and periphyton mat biomass at phosphorus enriched and unenriched sites within this area and found periphyton mat ash-free dry weight to be much lower in phosphorus enriched sites (ranging from 3 to $68 \mathrm{~g} \mathrm{AFDM} \mathrm{m}^{-2}$ ) when compared to un-enriched sites (ranging from 100 to $1600 \mathrm{~g} \mathrm{AFDM} \mathrm{m}^{-2}$ ). Two separate mesocosm studies conducted in the same area showed that periphyton mat biomass, measured as both AFDM and ash weight, decreased as mat TP increased (Pan et al., 2000) and that at high mat TP concentrations ( $>250 \mu \mathrm{g} \mathrm{g} \mathrm{g}^{-1}$ dry mass), mat biomass declined significantly, resulting in the elimination of metaphyton (floating periphyton mats) and complete disintegration of periphyton mats (McCormick et al., 2001).

In a 5-year dosing experiment conducted by Gaiser et al. (2004, 2005 and 2006), protracted low-level phosphorus addition demonstrated that periphyton mats were efficient at rapidly sequestering phosphorus from the water column, resulting in elevated mat TP concentrations (>150 $\mu \mathrm{g} \mathrm{g}^{-1}$ dry mass). They also found that mat DM and AFDM declined as mat TP increased, while ORG was positively correlated with mat phosphorus concentrations.

These studies illustrate that there exists a negative linear relationship between periphyton mat TP and biomass, and a positive linear relationship between periphyton mat TP and the proportion of organic matter within the mat. These two relationships were evident at both Everglades and Caribbean sites in the results of this study, where all but one of these relationships were significant; the exception being between ORG and 
mat TP content at the Caribbean sites, arguably the result of small sample size or inclusion of an anomalous sampling event from Belize.

The similarity in the nature of the influence of water depth and mat TP concentrations on mat biomass and ORG indicate that both are important in determining mat biomass. There is, however, a notable difference in the strength of these relationships. The relationship between mat TP and all the variables tested was consistently stronger than that between water depth and the tested variables. This suggests that phosphorus availability is the main driver of periphyton mat biomass, with water depth and the related changes in water chemistry (primarily pH levels and $\mathrm{CO}_{2}$ partial pressure), acting as enabling factors that regulate phosphorus availability within the water column (Scinto and Reddy, 2003).

As a major component of the tropical karstic wetland ecological structure, periphyton mats contribute to the physical architecture of the system, influence food web structure and regulate multiple biogeochemical processes. It is therefore reasonable to expect that any changes in the environmental conditions of the habitats where these mats are found could have profound effects on the functioning of the mats, and by extension, the wider wetland ecosystem. It is for this reason that efforts must be made to understand how environmental factors affect periphyton mat function, as this will allow us to better predict how anticipated climate change and environmental management decisions may impact these unique systems. In an effort to enhance our knowledge of periphyton mat ecology in tropical karstic wetlands and its impact on the ecology of the overall wetland system, it is also desirable to obtain information from as wide a range of such wetlands as is possible. 
Furthermore, the Everglades has been characterized as 'unique' by some authors (e.g., Noe et al. 2001), unintentionally questioning the generality of work done there. This study helps to establish a more general framework for understanding the ecology of the Everglades, while expanding the potential application of work done there to less wellstudied regions.

Future work will endeavor to incorporate more karstic wetlands from the Caribbean region, as well as increase the range of habitat types and number of sites sampled within these wetlands. In addition, studies conducted in the Everglades suggest that hydrology and water quality greatly influence other ecosystem components, such as food web structure (Liston et al., 2008; Chick et al., 2008) and diatom community composition (Gaiser et al., 2006; Slate and Stevenson, 2007). To enhance our understanding of these relationships, future work should seek to examine these relationships in a broader context within the Caribbean region.

\section{CONCLUSIONS}

The results of this study have served to clarify the distinct relationships between (i) water depth and mat ORG and (ii) periphyton mat TP concentrations and biomass in Everglades and Caribbean marshes and provide evidence to support the idea that the observed relationships are indeed characteristic of tropical karstic wetlands and not unique to the Everglades system. Results also show that water depth and periphyton mat TP content are both correlated with periphyton mat biomass in tropical karstic wetland systems, suggesting that they are drivers for periphyton mat dynamics in these systems. 


\section{ACKNOWLEDGMENTS}

The author would like to thank the Sian Ka'an Biosphere Reserve in Quintana Roo, Mexico and Lamanai Outpost in Orange Walk, Belize for facilitating site access and supporting this research. I also thank Clifton Ruehl, Raul Urgelles and collaborators from Universidad Nacional Autónoma de México for their assistance with the collection of field data from Mexico and Belize, and the Periphyton lab at Florida International University for data collection in the Everglades. This research was funded by the National Science Foundation under Grant No. DBI-0620409 and DEB-9910514, as well as a grant to J. La Hée from the Latin American Caribbean Center at Florida International University. The Southeast Environmental Research Center (SERC) at FIU also provided funding for this research. This is publication number $\mathrm{xxx}$ from SERC and $\mathrm{xxx}$ from the Tropical Biology Program of the Department of Biological Sciences at FIU. 


\section{LITERATURE CITED}

Azan S, Webber D (2007) The characterization and classification of the Black River Upper Morass, Jamaica, using the three-parameter test of vegetation, soils and hydrology. Aquatic Conservation: Marine and Freshwater Ecosystems 17:5-23

Bezuary CJ (2002) MPA perspective: mitigating the effects of coastal development on the Sian Ka'an Biosphere Reserve: a case example from México. Marine Protected Areas News 4:2

Browder JA, PJ Gleason, DR Swift (1994) Periphyton in the Everglades: spatial variation, environmental correlates, and ecological implications. In: Davis SM, Ogden JC (eds) Everglades: The Ecosystem and its Restoration. St. Lucie Press, Delray Beach, Florida, pp 379-418

Cairns CE, Villanueva-Gutiérrez R, Koptur S, Bray DB (2005) Bee populations, forest disturbance, and africanization in Mexico. Biotropica 37:686-692

Chick JH, Geddes P, Trexler JC (2008) Periphyton mat structure mediates trophic interactions in a subtropical wetland. Wetlands 28:378-389

Childers DL, Jones RD, Trexler J, Buzzelli C, Boyer J, Edwards A, Gaiser E, Jayachandaran K, Lee D, Meeder J, Pechmann J, Richards J, Scinto L (2001) Quantifying the effects of low level phosphorus enrichment on unimpacted Everglades wetlands with in situ flumes and phosphorus dosing. In: Porter J, Porter K, (eds) The Everglades, Florida Bay, and Coral Reefs of the Florida Keys. Boca Raton, Florida, USA: CRC Press, pp $127-52$

Cronberg G (1982) Plankton of the Negril and Black River Morasses, Jamaica. Report to the PCJ Kingston, Jamaica.

Davis M, Lalor GC, Rattray R (1998) Nutrient status of the Black River System, St.

Elizabeth, Jamaica. Jamaican Journal of Science and Technology 9:45-62 
Donar CM, Condon KW, Gantar M, Gaiser EE (2004) A new technique for examining the physical structure of Everglades floating periphyton mat. Nova Hedwigia 78:107-19

Enell M (1984) Water Chemistry of the Negril and Black River Morasses, Jamaica. Petroleum Corporation of Jamaica, Kingston, Jamiaca.

Gaiser EE, Scinto LJ, Richards JH, Jayachandrana K, Childers DL, Trexler JC, Jones RD (2004) Phosphorus in periphyton mats provides the best metric for detecting low-level P enrichment in an oligotrophic wetland. Water Research 38:507-516

Gaiser EE, Trexler JC, Richards JH, Childers DL, Lee D, Edwards AL, Scinto LJ, Jayachandran K, Noe GB, Jones RD (2005) Cascading ecological effects of low-level phosphorus enrichment in the Florida Everglades. Journal of Environmental Quality 34:717-723

Gaiser EE, Richards JH, Trexler JC, Jones RD, Childers DL (2006) Periphyton responses to eutrophication in the Florida Everglades: cross-system patterns of structural and compositional change. Limnology and Oceanograohy 51:617-630

Gaiser EE (2009) Periphyton as an indicator of restoration in the Florida Everglades. Ecological Indicators 9: S37-S45

Gleason PJ, Spackman W (1974) Calcareous periphyton and water chemistry in the Everglades. In: Gleason PJ (ed.) Environments of South Florida: Past and Present, Memoir No. 2. Miami Geological Society, Coral Gables, Florida, pp 225-248

Goldsborough LG, Robinson GGC (1996) Pattern in wetlands. In: Stevenson RJ, Bothwell ML, Lowe RL (eds.) Algal Ecology in Freshwater Benthic Ecosystems. Academic Press, pp 77-117

Gottlieb AD, Richards JH, Gaiser EE (2006) Comparative study of periphyton community structure in long and short hydroperiod Everglades marshes. Hydrobiologia 569:195-207 
Grimshaw HJ, Rosen M, Swift DR, Rodberg K, Noel JM (1993) Marsh phosphorus concentrations, phosphorus content and species composition of Everglades periphyton communities. Archiv für Hydrobiologie 128:257-276

Gunderson LH (1994) Vegetation of the Everglades: Determinants of community composition. In: Davis SM, Ogden JC (eds) Everglades: The Ecosystem and its Restoration. St. Lucie Press, Delray Beach, Florida, pp 323-340

Iwaniec DM, Childers DL, Rondeau D, Madden CJ, Saunders CJ (2006) Effects of hydrologic and water quality drivers on periphyton dynamics in the southern Everglades. Hydrobiologia 569:223-235

Liston SE, Newman S, Trexler JC (2008) Macroinvertebrate community response to eutrophication in an oligotrophic wetland: An in situ mesocosm experiment. Wetlands 28:686-694

Massa AK, Haynes-Sutton A (1998) Environmental Policy Framework, Parish of St. Elizabeth, Jamaica. Technical Support Services Inc. Prepared for the Natural Resources Conservation Authority Protected Areas Management Branch and the United States Agency for International Development.

McCormick PV, O’Dell MB (1996) Quantifying periphyton responses to phosphorus in the Florida Everglades: a synoptic-experimental approach Journal of the North American Benthological Society 15:450-468

McCormick PV, Rawlik PS, Lurding K, Smith EP, Sklar FH (1996) Periphyton-water quality relationships along a nutrient gradient in the northern Everglades. Journal of the North American Benthological Society 15: 433-449

McCormick PV, Stevenson RJ (1998) Periphyton as a tool for ecological assessment and management in the Florida Everglades. Journal of Phycology 34:726-733

McCormick PV, Shuford III RBE, Backus JB, Kennedy WC (1998) Spatial and seasonal patterns of periphyton biomass and productivity in the northern Everglades, FL, USA. Hydrobiologia 362:185-208 
McCune B, Grace JB (2002) Analysis of Ecological Communities, MJM Press, Gleneden Beach, Oregon, USA

Meerman JC (2006) Ecological Characterization of the New River Lagoon, Orange Walk District, Belize. Report prepared for the Freshwater Programme for Belize, Belize City

Merz Martina UE (1992) The biology of carbonate precipitation by cyanobacteria. Facies 26:81-102

Noe, G. B., Childers, D.L., Jones, R. D. 2001. Phosphorus biogeochemistry and the impact of phosphorus enrichment: Why is the Everglades so unique? Ecosystems 4: 603624.

Noe GB, Childers DL, Edwards AL, Gaiser E, Jayachandaran K, Lee D, Meeder J, Richards J, Scinto LJ, Trexler J, Jones RD (2002) Short-term changes in phosphorus storage in an oligotrophic Everglades wetland ecosystem receiving experimental nutrient enrichment. Biogeochemistry 59:239-67

Noe GB, Childers DL (2007) Phosphorus budgets in Everglades wetland ecosystems: the effects of hydrology and nutrient enrichment. Wetlands Ecology Management 15:189205

Novelo E, Tavera R, Ibarra C (2007) Bacillariophyceae from Karstic Wetlands in Mexico. Bibliotheca Diatomologica 54:1-136

Novelo E, Tavera R (2003) The role of periphyton in the regulation and supply of nutrients in a wetland at El Edén, Quintana Roo. In: Gómez-Pompa A, Allen MF, Fedick SL, Jiménez-Osornio JJ (eds.) The Lowland Maya Area. Three Millennia and the Human-Wildland Interface. Food Products Press, NY, pp 217-239

Otsuki A, Wetzel RG (1972) Coprecipitation of phosphate with carbonates in a marl lake. Limnology and Oceanography 17:763-767

Pentecost A, Whitton BA (2000) Limestones. In: Whitton BA, Potts M (eds) The Ecology of Cyanobacteria, Kluwer Academic Publishers, Netherlands, pp 257-279 
Rejmánková E, Pope KO, Post R, Maltby E (1996) Herbaceous wetlands of the Yucatan peninsula: communities at extreme ends of environmental gradients. Internationale Revue der Gesamten Hydrobiologie 81:223-252

Rejmánková E, Komárková J (2000) Function of cyanobacterial mats in phosphoruslimited tropical wetlands. Hydrobiologia 431:135-153

Rejmánková E (2001) Effect of experimental phosphorus enrichment on oligotrophic tropical marshes in Belize, Central America. Plant Soil 236:33-53

Richardson CJ (2009) The Everglades: North America's subtropical wetland. Wetlands Ecology and Management, DOI: 10.1007/s11273-009-9156-4.

Scinto LJ, Reddy KR (2003) Biotic and abiotic uptake of phosphorus by periphyton in a subtropical freshwater wetland. Aquatic Botany 77:203-222

Slate JE, Stevenson RJ (2007) The diatom flora of phosphorus enriched and unenriched sites in an Everglades marsh. Diatom Research 22:355-386

Solórzano JH, Sharp L (1980) Determination of total dissolved phosphorous and particulate phosphorous in natural waters, Limnology and Oceanography 25:754-758

Stal LJ (2000) Cyanobacterial mats and stromatolites. In: Whitton BA, Potts M (eds) The Ecology of Cyanobacteria: Their Diversity in Time and Space. Kluwer Academic Publishers, Dordrecht, The Netherlands, pp 61-120

Swift DR, Nicholas RB (1987) Periphyton and water quality relationships in the Everglades Water Conservation Areas, 1978-1982. Technical Publication 872, South Florida Water Management District, West Palm Beach, Florida

Thomas S, Gaiser EE, Gantar M, Scinto L, Jones RD (2006) Quantifying the response of calcareous periphyton crusts to rehydration: a microcosm study (Florida Everglades). Aquatic Botany 84:317-323 
Van Meter-Kasanof N (1973) Ecology of the microalgae of the Florida Everglades. Part I. Environment and some aspects of freshwater periphyton, 1959 to 1963 . Nova Hedwigia 24:619-664

Weidie AE (1985) Geology of the Yucatan platform. In: Ward WC, Weidie AE, Back W (eds) Geology and hydrology of the Yucatan and Quaternary geology of northeastern Yucatan peninsula New Orleans Geological Society, pp 1-19

Welschmeyer NA (1994) Fluorometric analysis of chlorophyll $a$ in the presence of chlorophyll $b$ and pheopigments. Limnology and Oceanography 39:1985-1992

Williams AJ, Trexler JC (2006) A preliminary analysis of the correlation of food-web characteristics with hydrology and nutrient gradients in the southern Everglades.

Hydrobiologia 569:493-504

Wood EJF, Maynard NG (1974) Ecology of the microalgae of the Florida Everglades. In Gleason PJ (ed) Environments of South Florida: Past and Present, Memoir No. 2.Miami Geological Society, Coral Gables, Florida, pp 123-145 
Table 2-1. Location of Caribbean sampling sites, presented as latitudinal and longitudinal bounding GPS coordinates of sampling sites within each location.

\begin{tabular}{llll}
\hline $\begin{array}{l}\text { Bounding GPS } \\
\text { coordinates of }\end{array}$ & $\begin{array}{l}\text { Sian Ka'an National } \\
\text { Park, Quintana Roo, }\end{array}$ & $\begin{array}{l}\text { New River Lagoon, } \\
\text { Indian Church, }\end{array}$ & $\begin{array}{l}\text { Slipe River, Black } \\
\text { River Morass, St. } \\
\text { sampling sites }\end{array}$ \\
Mexico & Belize & Elizabeth, Jamaica \\
\hline EAST & $087^{\circ} 30.585$ & $88^{\circ} 37.958^{\prime}$ & $78^{\circ} 46.972$ \\
WEST & $087^{\circ} 57.579$ & $88^{\circ} 39.212^{\prime}$ & $77^{\circ} 48.874$ \\
NORTH & $1^{\circ} 52.342$ & $17^{\circ} 47.111^{\prime}$ & $18^{\circ} 03.182$ \\
SOUTH & $18^{\circ} 47.223$ & $17^{\circ} 37.166$ & $18^{\circ} 01.524$ \\
\hline
\end{tabular}

Table 2-2. Number of sites sampled $(\mathrm{N})$, water characteristics and periphyton attributes for each location during wet and dry periods. Average values are given along with standard deviation values in brackets. Missing data are indicated with a dash (-).

\begin{tabular}{|c|c|c|c|c|c|c|c|c|c|c|c|c|}
\hline SITE & $\mathrm{N}$ & $\mathrm{pH}$ & $\begin{array}{c}\text { COND } \\
\left(\mu \mathrm{S} \mathrm{cm}^{-1}\right)\end{array}$ & $\begin{array}{l}\text { WD } \\
(\mathrm{cm})\end{array}$ & $\begin{array}{c}\text { TBV } \\
\left(\mathrm{ml} \mathrm{m}^{-2}\right)\end{array}$ & $\begin{array}{c}\text { BV } \\
\left(\mathrm{ml} \mathrm{m}^{-2}\right)\end{array}$ & $\begin{array}{c}\mathrm{TP} \\
\left(\mu \mathrm{g} \mathrm{P} \mathrm{g}^{-1} \mathrm{DM}\right)\end{array}$ & $\begin{array}{c}\mathrm{DM} \\
\left(\mathrm{g} \mathrm{m}^{-2}\right)\end{array}$ & $\begin{array}{c}\text { ORG } \\
(\%)\end{array}$ & $\begin{array}{l}\text { AFDM } \\
\left(\mathrm{g} \mathrm{m}^{-2}\right)\end{array}$ & $\begin{array}{c}\mathrm{CH} \\
\left(\mu \mathrm{g} \mathrm{m}^{-2}\right)\end{array}$ & $\begin{array}{c}\mathrm{CHC} \\
\left(\mu \mathrm{g} \mathrm{g}^{-1} \mathrm{DM}\right)\end{array}$ \\
\hline Belize-Wet & 12 & $\begin{array}{c}7.3 \\
(0.5)\end{array}$ & $\begin{array}{c}441.8 \\
(208.6)\end{array}$ & $\begin{array}{l}73.2 \\
(8.5)\end{array}$ & $\begin{array}{c}876.0 \\
(1474.8)\end{array}$ & $\begin{array}{c}857.1 \\
(1486.4)\end{array}$ & $\begin{array}{c}239.7 \\
(106.7)\end{array}$ & $\begin{array}{c}77.1 \\
(133.4)\end{array}$ & $\begin{array}{c}67.8 \\
(19.1)\end{array}$ & $\begin{array}{c}30.1 \\
(48.2)\end{array}$ & $\begin{array}{c}140.2 \\
(132.7)\end{array}$ & $\begin{array}{c}48.3 \\
(52.5)\end{array}$ \\
\hline Belize-Dry & 9 & $\begin{array}{c}8.3 \\
(0.2)\end{array}$ & $\begin{array}{c}690.3 \\
(104.0)\end{array}$ & $\begin{array}{c}31.6 \\
(11.8)\end{array}$ & $\begin{array}{c}101.6 \\
(264.6)\end{array}$ & $\begin{array}{c}101.6 \\
(264.6)\end{array}$ & $\begin{array}{c}543.1 \\
(187.9)\end{array}$ & $\begin{array}{c}3.2 \\
(6.7)\end{array}$ & $\begin{array}{c}37.4 \\
(17.9)\end{array}$ & $\begin{array}{c}1.5 \\
(3.0)\end{array}$ & $\begin{array}{c}1288.5 \\
(2602.0)\end{array}$ & $\begin{array}{c}260.6 \\
(175.0)\end{array}$ \\
\hline Jamaica-Dry & 5 & $\begin{array}{c}8.4 \\
(0.5)\end{array}$ & $\begin{array}{c}447.6 \\
(137.3)\end{array}$ & $\begin{array}{c}11.6 \\
(12.7)\end{array}$ & $\begin{array}{c}2251.3 \\
(1712.6)\end{array}$ & $\begin{array}{c}2251.3 \\
(1712.6)\end{array}$ & $\begin{array}{l}200.3 \\
(16.5)\end{array}$ & $\begin{array}{c}156.0 \\
(104.8)\end{array}$ & $\begin{array}{l}28.7 \\
(7.2)\end{array}$ & $\begin{array}{l}39.4 \\
(25.5)\end{array}$ & $\begin{array}{c}29693.0 \\
(19940.6)\end{array}$ & $\begin{array}{l}222.5 \\
(83.1)\end{array}$ \\
\hline Mexico-Wet & 6 & - & $\begin{array}{l}1259.0 \\
(952.5)\end{array}$ & $\begin{array}{c}37.9 \\
(10.3)\end{array}$ & $\begin{array}{c}7460.7 \\
(3043.8)\end{array}$ & $\begin{array}{c}6772.6 \\
(2957.6)\end{array}$ & $\begin{array}{l}212.5 \\
(93.7)\end{array}$ & $\begin{array}{c}365.0 \\
(195.5)\end{array}$ & $\begin{array}{l}37.9 \\
(7.4)\end{array}$ & $\begin{array}{l}121.4 \\
(49.5)\end{array}$ & $\begin{array}{c}37195.4 \\
(12261.7)\end{array}$ & $\begin{array}{l}129.7 \\
(51.5)\end{array}$ \\
\hline Mexico-Dry & 4 & $\begin{array}{c}9.2 \\
(0.4)\end{array}$ & $\begin{array}{c}15047.7 \\
(16670.5)\end{array}$ & $\begin{array}{c}30.3 \\
(23.4)\end{array}$ & $\begin{array}{c}4564.3 \\
(2568.5)\end{array}$ & $\begin{array}{l}4144.6 \\
(2720)\end{array}$ & $\begin{array}{c}193.7 \\
(210.9)\end{array}$ & $\begin{array}{c}317.4 \\
(233.9)\end{array}$ & $\begin{array}{c}42.5 \\
(15.5)\end{array}$ & $\begin{array}{l}109.4 \\
(76.5)\end{array}$ & $\begin{array}{c}133456.4 \\
(153012.9)\end{array}$ & $\begin{array}{c}465.3 \\
(257.1)\end{array}$ \\
\hline Everglades-Wet & 55 & $\begin{array}{c}7.2 \\
(0.3)\end{array}$ & $\begin{array}{c}496.1 \\
(525.3)\end{array}$ & $\begin{array}{c}54.5 \\
(20.5)\end{array}$ & $\begin{array}{c}3993.8 \\
(2950.7)\end{array}$ & $\begin{array}{c}3352.5 \\
(3003.0)\end{array}$ & $\begin{array}{c}146.0 \\
(111.1)\end{array}$ & $\begin{array}{c}303.4 \\
(371.5)\end{array}$ & $\begin{array}{c}49.9 \\
(19.0)\end{array}$ & $\begin{array}{c}96.9 \\
(95.9)\end{array}$ & $\begin{array}{c}12995.2 \\
(10945.1)\end{array}$ & $\begin{array}{c}143.5 \\
(131.4)\end{array}$ \\
\hline Everglades-Dry & 55 & $\begin{array}{c}7.4 \\
(0.3)\end{array}$ & $\begin{array}{c}445.9 \\
(261.7)\end{array}$ & $\begin{array}{c}39.4 \\
(21.1)\end{array}$ & $\begin{array}{c}4784.8 \\
(3149.9)\end{array}$ & $\begin{array}{c}3756.8 \\
(2980.6)\end{array}$ & $\begin{array}{c}157.1 \\
(104.1)\end{array}$ & $\begin{array}{c}333.1 \\
(433.2)\end{array}$ & $\begin{array}{c}46.6 \\
(16.8)\end{array}$ & $\begin{array}{c}109.6 \\
(117.9)\end{array}$ & $\begin{array}{c}17114.8 \\
(11727.4)\end{array}$ & $\begin{array}{c}159.1 \\
(201.1)\end{array}$ \\
\hline
\end{tabular}




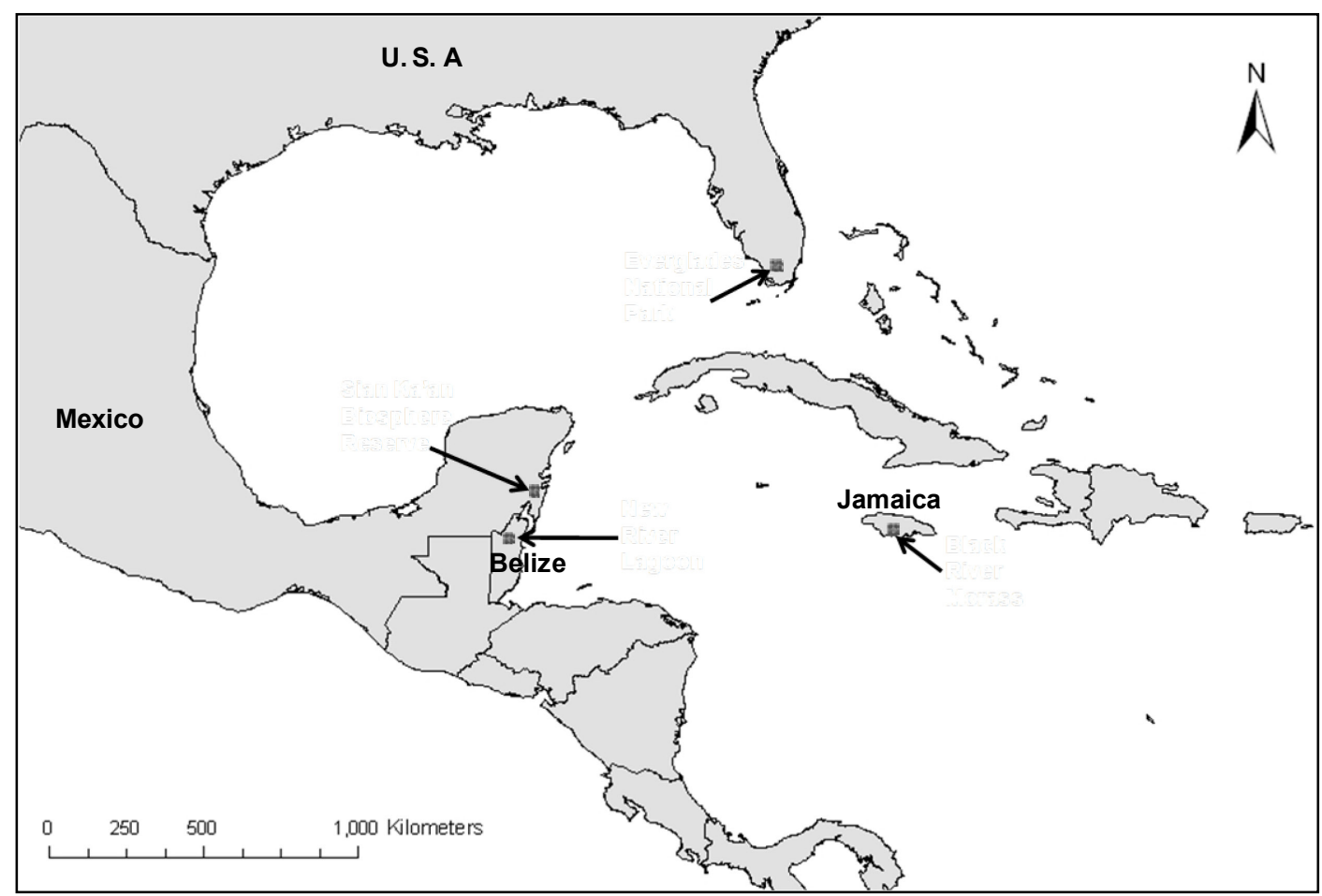

Figure 2-1. Map of northern Caribbean region showing the four sampling locations for this study. 

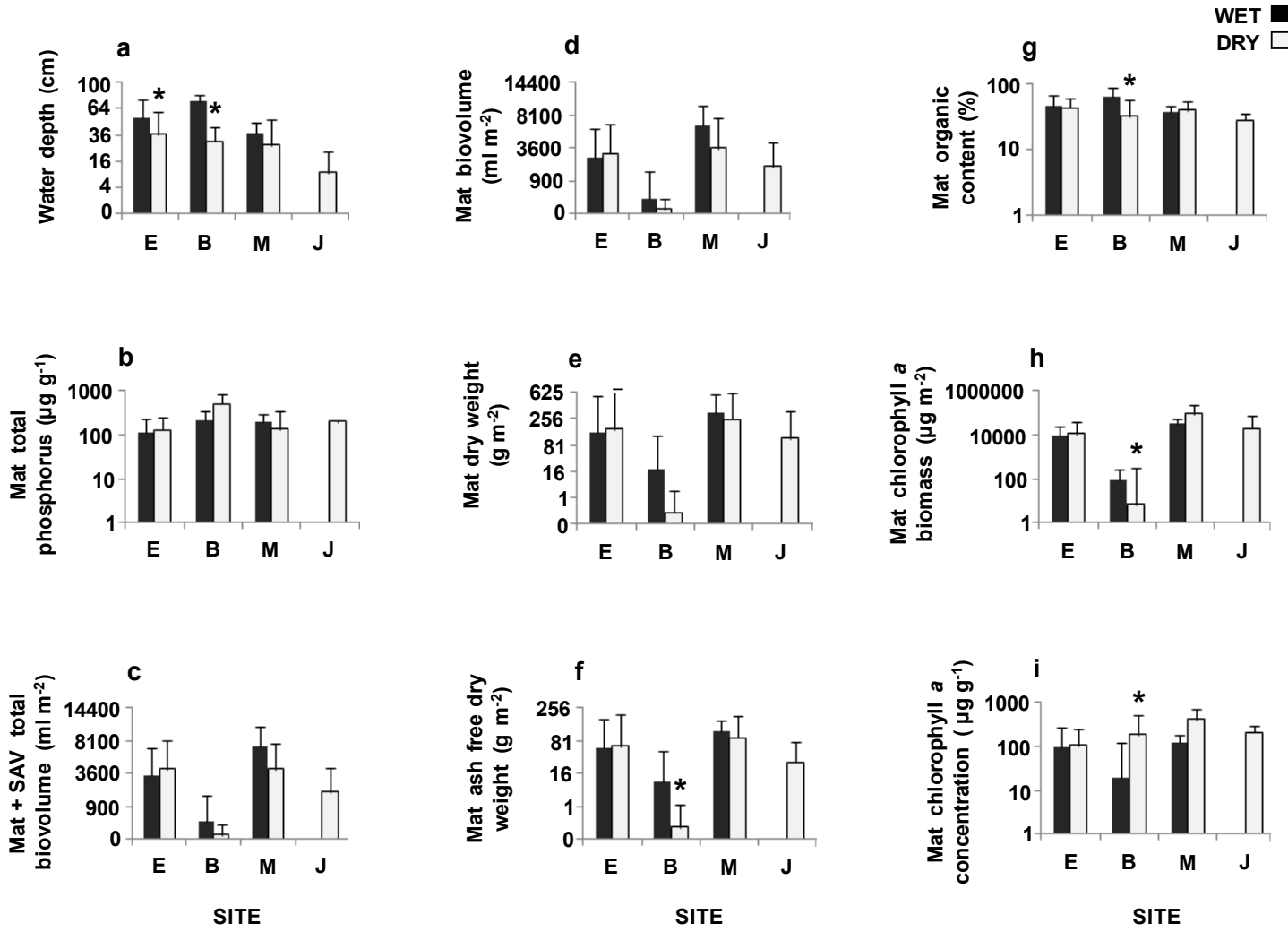

Figure 2-2. Bar graphs showing average values for all measured variables during wet and dry sampling periods at Everglades (E), Belize (B), Mexico (M) and Jamaica (J) sites. Graphs were created using transformed values for each variable and $\mathrm{X}$ and $\mathrm{Y}$ axes are scaled to facilitate transformed values. Error bars represent one standard deviation. Columns marked with an asterisk indicate a significant difference (ANOVA and Tukey's test, $\mathrm{p}<0.05$ ) between average values during the wet and dry period. 

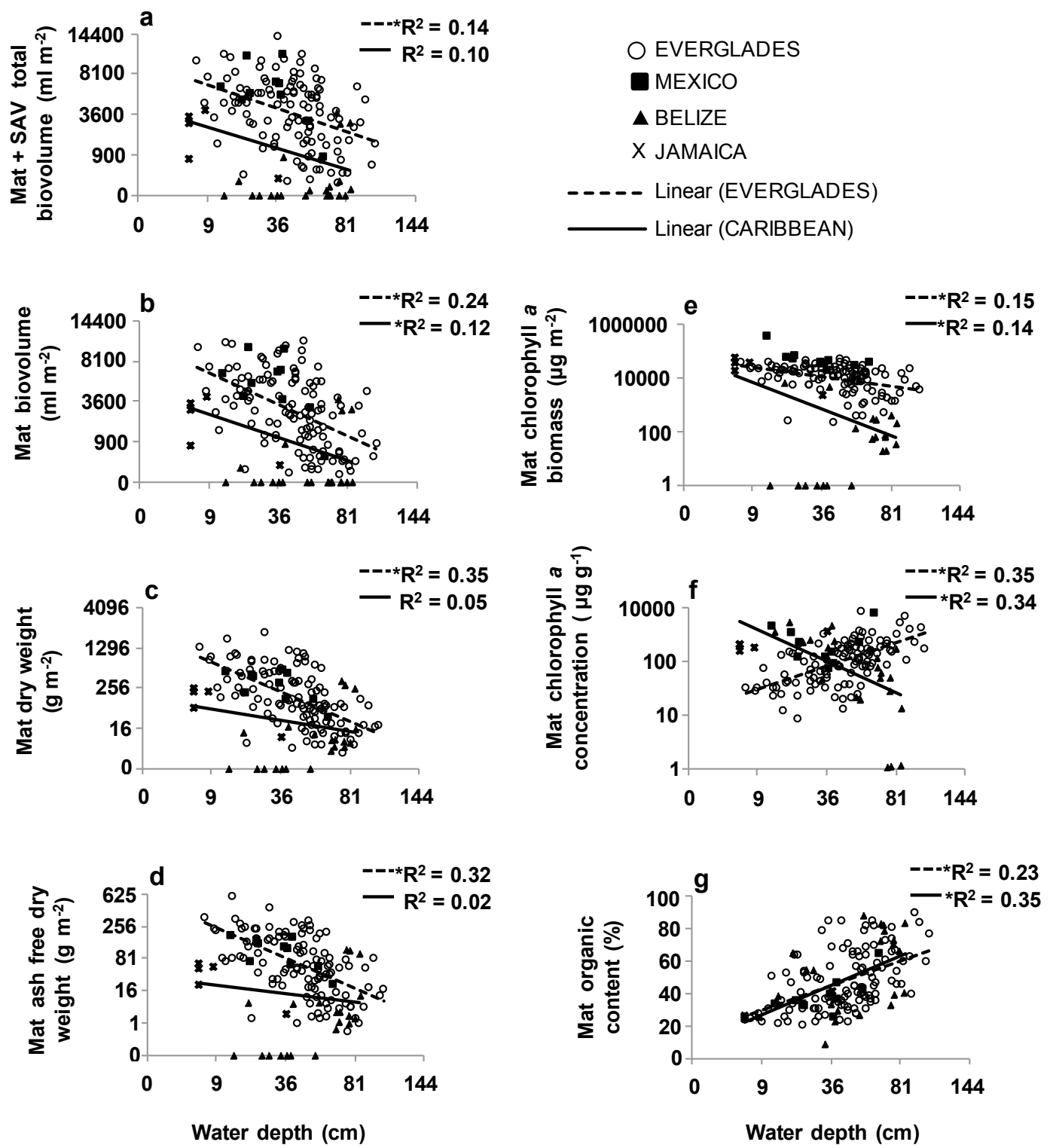

Figure 2-3. Scatterplots showing relationships between water depth and all other measured variables at each site. Graphs were created using transformed values for each variable. $\mathrm{X}$ and $\mathrm{Y}$ axes were scaled to facilitate transformed values. Two sets of regression lines and $\mathrm{R}^{2}$ values are shown. The dashed line describes data from all the Everglades sites and the solid line describes the combined dataset from the Caribbean sites. $\mathrm{R}^{2}$ values marked with an asterisk indicate a significant correlation between the variables $(\mathrm{p}<0.01)$. 


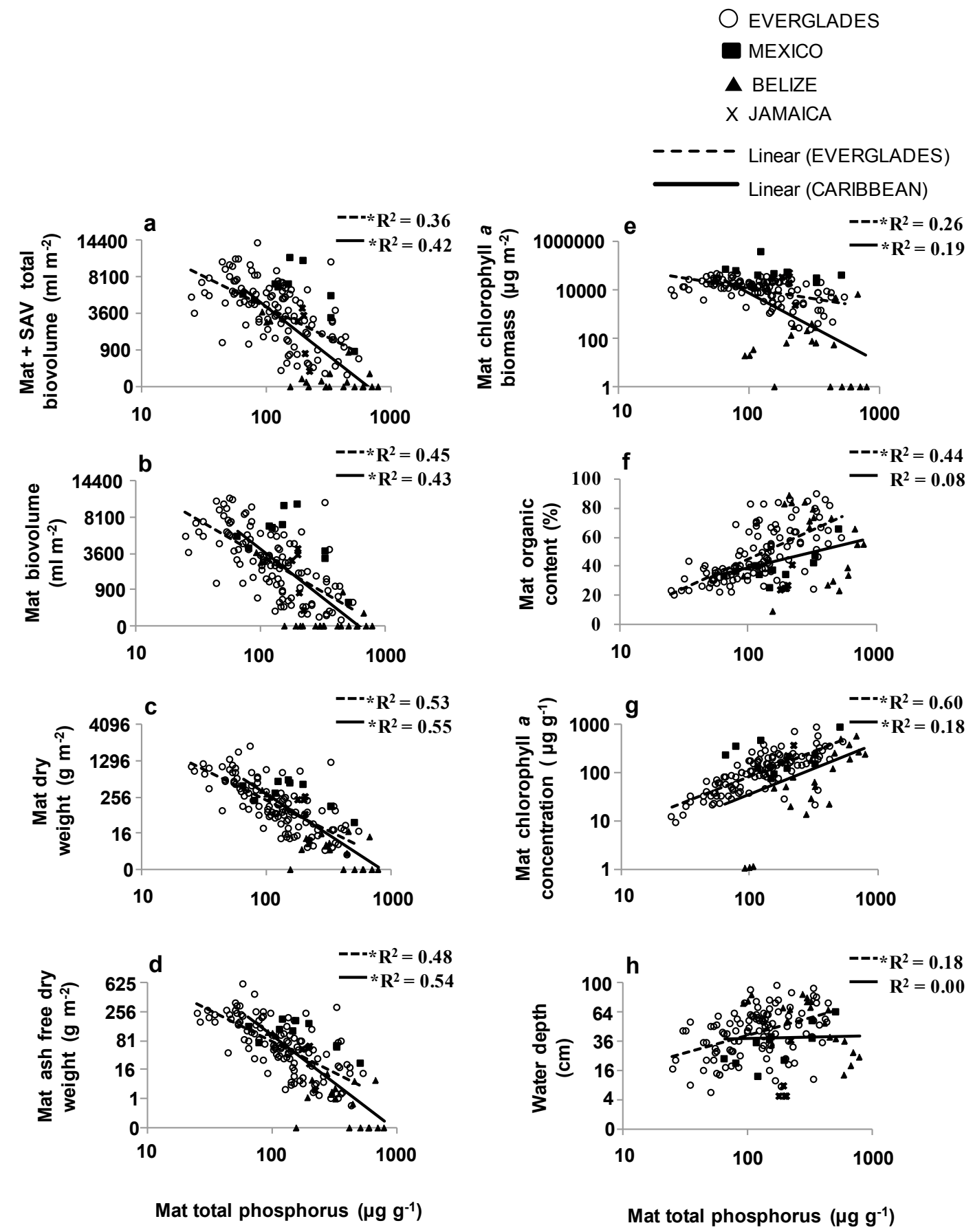

Figure 2-4. Scatterplots showing relationships between periphyton TP and all other measured variables at all sites. Graphs were created using transformed values for each variable. $\mathrm{X}$ and $\mathrm{Y}$ axes were scaled to facilitate transformed values. Two sets of regression lines, equations and $\mathrm{R}^{2}$ values are shown. The dashed line describes data from all the Everglades sites and the solid line describes the combined dataset from the Caribbean sites. $\mathrm{R}^{2}$ values marked with an asterisk indicate a significant correlation between the variables $(\mathrm{p}<0.001)$. 

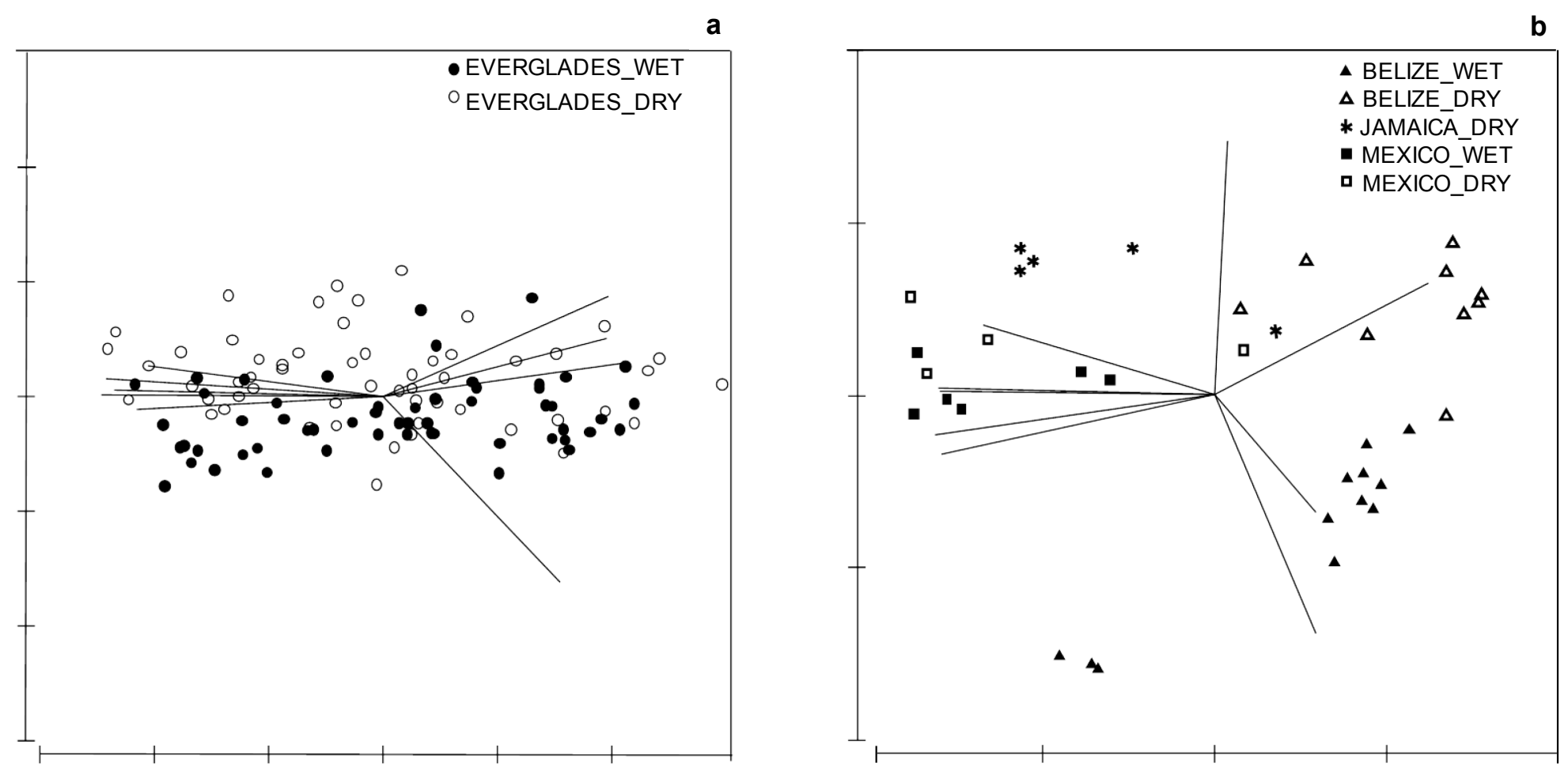

Figure 2-5. Principle component analysis joint plots of Everglades sites (a) and Caribbean sites (including M, B, J data) (b). Vectors on each plot represent the direction and strength of the relationship among environmental variables and periphyton attributes. 


\title{
CHAPTER III
}

Diatom species of calcitic periphyton mats from karstic wetland habitats in Belize, Mexico and Jamaica

\begin{abstract}
The diatom assemblage associated with calcitic periphyton mats from karstic wetlands in the Everglades is distinct and includes a core group of species that may be considered endemic to this type of habitat. Little is known about the diatom assemblage from similar karstic wetlands throughout the Caribbean and Central American region. This study was therefore conducted to produce a taxonomic inventory of the diatom species of periphyton mats from multiple karstic wetlands within the region.

Diatoms were identified from periphyton mats collected during wet and dry periods from similar shallow, karstic freshwater wetland habitats in Belize, Mexico and Jamaica. A comprehensive species list was produced, along with photomicrographs, morphological descriptions and autecological information for each species.

A total of 146 diatom species representing 39 genera were recorded from the three locations. Twenty eight of these species were found to be present at all three locations and the most common among these (with average abundances greater than $1 \%$ at all locations) included Brachysira neoexilis, Encyonema evergladianum, Encyonema spp., Fragilaria syngrotesca, Mastogloia smithii var. lacustris, Mastogloia smithii, Navicula cryptotenella, Nitzschia palaea and Nitzschia serpentiraphe.
\end{abstract}




\section{INTRODUCTION}

Throughout the Caribbean and Central American region, freshwater karstic wetlands occur as expanses of inundated coastal and inland plains, underlain by ancient limestone bedrock. The natural variation in topography and hydrology across these wetland landscapes produces a patchwork of habitat types, including extensive shallow, marl-based marshes, which are characterized by low water phosphorus $(\mathrm{P})$ concentrations $\left(<10 \mu \mathrm{g} \mathrm{L}^{1}\right)$, a distinctive macrophyte community and the prolific growth of calcitic, cyanobacterial mats (Browder et al., 1994; Gunderson, 1994; Rejmánková and Komárková, 2000; Novelo and Tavera, 2003; Gaiser et al., 2006).

These consolidated mats are referred to as "periphyton mats" because of their tendency to grow as attached masses on benthic substrates, as well as submerged and floating vegetation (Van-Meter Kasanof, 1973; Browder, 1982; Figure 3-1). Filamentous cyanobacteria (primarily Schizothrix spp. and Scytonema spp.) dominate the periphyton mat assemblage, forming an interwoven structure in which diatoms, green algae, desmids, heterotrophic bacteria and fungi grow amid polysaccharide mucilage strands and interstitial deposits of calcium carbonate (Van Meter-Kasanof, 1973; Swift and Nicholas, 1987; Donar et al., 2004; Stal, 2000; Rejmánková and Komárková, 2000). Periphyton mat ecology has been most intensely studied in the southern Florida

Everglades, an approximately $5,000 \mathrm{~km}^{2}$ karstic wetland system in which anthropogenic alterations to hydrological regimes and water quality have prompted investigations into the use of periphyton mats as indicators of environmental stress and recovery (McCormick and Stevenson1998; Noe and Childers, 2007; Gaiser et al., 2004). Within 
this system, periphyton mats have been noted for their large standing crop and high productivity (Browder et al., 1994; Goldsborough and Robinson, 1996; Ewe et al., 2006; Gaiser, 2009), as well as their importance as a food source for microinvertebrates, macroinvertebrates and fish, (Williams and Trexler, 2006; Liston et al., 2008). As biogeochemical regulators, periphyton mats also facilitate the deposition of calcium carbonate throughout the system, influence the production of detrital floc (Neto et al., 2006) and are responsible for diurnal and annual changes in water chemistry (McCormick et al., 2001; Munyon, in prep.). Because the Everglades is an extremely oligotrophic system in which phosphorus $(\mathrm{P})$ is the main limiting nutrient (Noe et al., 2001), the rapid uptake and assimilation of $\mathrm{P}$ by periphyton mats is also of particular importance (McCormick and Scinto, 1999; Scinto and Reddy, 2003). In the Everglades elevated periphyton mat TP concentrations serve as a reliable metric of TP inputs to the system (Gaiser et al., 2005) and anomalous decreases in overall periphyton mat mass and increases in organic content in response to elevated TP concentrations, serve as early indicators of nutrient enrichment (Pan et al., 2000; McCormick et al., 2001; Gaiser et al., 2006).

Within the Everglades, diatoms have been identified as being a particularly important periphyton mat component, contributing to both mat form and function. The organic matrix of mucopolysaccharide threads produced by certain species of attached and motile diatoms (e.g. Gomphonema spp. and Mastogloia smithii) encourages periphyton mat cohesion and, along with cyanobacterial mucilage sheaths, aid in resistance to mat desiccation (Azim and Asaeda, 2005; Donar et al., 2004; Thomas et al., 2004; Gaiser et al., 2010). The copious production of glycocalyx also serves as an 
extracellular organic reservoir of nutrients that may sustain microbial activity under oligotrophic conditions and stimulate microbial heterotrophic activity following extended periods of desiccation (Gaiser et al., 2010; Hagerthey et al., in press).

Taxonomic studies have identified a distinctive assemblage of Everglades diatom species (including Brachysira neoexilis, Encyonema evergladianum, Encyonema spp., Fragilaria syngrotesca, Mastogloia smithii var. lacustris, Mastogloia smithii, Navicula cryptotenella, Nitzschia palaea and Nitzschia serpentiraphe) that has not been reported from other habitat types and is possibly endemic to subtropical/tropical freshwater karstic wetlands (Slate and Stevenson, 2000 and 2007; Gaiser et al., 2006). Many of these species exhibit a low tolerance for nutrient enrichment (McCormick et al., 1996; Cooper et al., 1999; Slate and Stevenson, 2007) and under enriched conditions, the endemic diatom assemblage is replaced by one dominated by 'weedy' benthic taxa (Swift and Nicholas, 1987; Grimshaw et al., 1993; McCormick and O’Dell, 1996; Pan et al., 2000). The established relationship between periphytic diatom assemblage and TP has been used to develop diatom based calibration models to infer water (Slate and Stevenson, 2007), soil (Cooper et al., 1999) and periphyton mat (Gaiser et al., 2006) TP concentrations within the Everglades, as well as indicate past environmental conditions and identify anthropogenically driven changes to the system using paleoecological techniques (Slate and Stevenson, 2000).

Very little work has been conducted on periphyton mats from other karstic wetland habitats within the region. However, from the few studies which have been done, it is known that in these systems, patterns of $\mathrm{P}$ uptake by periphyton mats (Rejmánková and Komárková, 2005) and changes in mat biomass in response to P 
enrichment (La Hée et al., in prep.) are consistent with patterns identified in the Everglades. In addition, one survey of diatom assemblages from periphyton mats in the El Eden Ecological Reserve in Quintana Roo, Mexico, (Novelo et al., 2007; Ibarra et al., 2009) has identified diatom species representative of the distinctive core assemblage characteristic of Everglades periphyton mats. These findings confirm the similarity among these systems and help to further characterize the anomalous relationship between periphyton mat attributes and eutrophication, which though previously thought to be unique to the Everglades, now seems to be typical of tropical/sub-tropical karstic wetland systems in this region. Furthermore, these studies provide information which suggests that diatom-based inference models, such as those developed within the Everglades, may be a useful tool for tracking environmental changes within these systems.

The development of useful inference models is contingent on the availability of taxonomic and ecological information for the region of interest. At present, however, there is a pervasive lack of such information throughout much of the Caribbean and Central American region. The main aim of this study is therefore to supplement the body of information currently available for this region by providing a taxonomic inventory of the diatom species of periphyton mats from wetlands in Belize, Mexico, Jamaica. A comprehensive species list for three Caribben karstic wetlands is herein presented, along with photomicrographs, morphological descriptions and autecological information for each species. This information may be used in future studies as a basis for developing site-specific, diatom-based environmental inference models. 


\section{SITE DESCRIPTION}

Sampling was conducted in three wetland systems, similar with respect to geology, climate, hydrology and vegetation, located within the northern Caribbean Basin: the Sian Ka'an Biosphere Reserve (and areas to the south), in Quintana Roo, Mexico; the New River Lagoon in Orange Walk, Belize; and the Broad River, in the Black River Morass, St. Elizabeth, Jamaica (Figure 3-2, Table 3-1).

The Sian Ka'an Biosphere Reserve and the wetlands extending beyond its boundary to the south, encompass a $6500 \mathrm{~km}^{2}$ area along the south eastern coast of the Yucatan Peninsula in Quintana Roo, Mexico (Cairns et al., 2005). The Yucatan peninsula is an uplifted marine platform which extends from the greater Yucatan platform and serves as a divide between the Gulf of Mexico and the Caribbean Sea. The geological formation is a 2 to $3 \mathrm{~km}$ thick sequence dominated by limestone, with intermittent layers

of dolomite, anhydrite and gypsum (Weidie, 1985). The karstic wetland marshes located within the Yucatan region are dominated by low phosphorus, inland freshwater, marl based habitats and coastal mesohaline habitats. The most common freshwater macrophytic species include Cladium jamaicense (sawgrass), Eleocharis spp. (spikerush) and Typha domingensis (southern cattail), each of which tends to become dominant at low, intermediate and high water depths, respectively (Rejmánková et al., 1996). Dwarfed populations of Rhizophora mangle (red mangrove) become more abundant as salinity levels increase, and form the dominant tree species in the coastal brackish water marshes. Calcitic periphyton mats are abundant in both freshwater and brackish water habitats with marl substrates (Rejmánková et al., 1996). Inland sampling sites were 
confined to freshwater, Eleocharis spp. Marshes, and closer to the coast, brackish water sites dominated by dwarf Rhizophora mangle were sampled.

The New River Lagoon, located in the district of Orange Walk to the north of Belize, is an approximately $23 \mathrm{~km}$ long and $750 \mathrm{~m}$ wide stretch of the New River, which is the longest river contained entirely within Belize (Meerman, 2006). The area lies just to the southeast of the basal portion of the Yucatan peninsula and exhibits geological features similar to the adjacent landmass (Weidie, 1985). The New River Lagoon is flanked by marshes dominated mainly by Cladium jamaicense, Eleocharis cellulosa and Eleocharis interstincta, with intermittent deeper pools supporting dense assemblages of Nymphea ampla (dotleaf waterlilly). Sampling sites in this area were again confined to Eleocharis spp. marshes adjacent to the lagoon.

The Black River Morass encompasses the largest wetland and river system within the Greater and Lesser Antillean archipelago (Davis et al., 1998; Massa and HaynesSutton, 1998). It lies within the Black River Basin, which occupies an area of approximately $1,488 \mathrm{~km}^{2}$ in the south-western region of Jamaica. The area is divided into two main sections: the Upper and Lower Morass. The Upper Morass is approximately $97 \mathrm{~km}^{2}$ (Cronberg, 1983) and is composed of a mass of swampy lowlands with limestone bedrock covered by peat deposits. The Lower Morass which is approximately $57 \mathrm{~km}^{2}$ (Enell, 1984), exists as an area of down-faulted, poorly karstified limestone, overlain by a relatively thin clay and peat sequence. Inland marsh areas display mixed vegetation dominated by Cladium jamaicense and Eleocharis spp., with large stands of Typha domingensis being present in some areas (Azan and Webber, 2007). Closer to the coast, assemblages dominated by Rhizophora mangle are prevalent 
and these trees can also be found bordering the main waterways as they meander through the wetland system. Sampling sites were located within Cladium jamaicense and Eleocharis marshes bordering the Broad River, a major tributary of the Black River.

\section{METHODS}

\section{$\underline{\text { Sample collection }}$}

Each of the Caribbean study locations was visited on two occasions; once during a wet period and once during a dry period. As a result of abnormal seasonal rainfall patterns during the study period, wet and dry periods did not necessarily coincide with the typical regional wet and dry seasons. "Wet" and "dry" designations were therefore applied on the basis of rainfall levels at each location during the sampling period, relative to typical wet and dry seasonal rainfall levels. The Everglades samples were collected during October to December, 2005 (Wet period) and September to December, 2006 (Dry period) as part of the periphyton component of the CERP seasonal sampling regime. The Mexico sites were visited in December 2006 (Wet period) and March 2008 (Dry period), the Belize sites in May 2007 (Dry period) and November 2007 (Wet period), and the Jamaica sites in December, 2007 (Wet period) and May 2008 (Dry period). Efforts were made to conduct sampling at as many sites as possible, however during dry periods the number of sites sampled varied according to the ability to locate areas that sustained water levels greater than $5 \mathrm{~cm}$. During wet periods, sampling efforts were contingent on the ability to gain access to sites, and were then limited to sites that did not exceed water depths of approximately $1 \mathrm{~m}$. 
At each location, sampling sites were limited to three main types of wetland areas: (i) marshes dominated by Eleocharis spp. and/or Nymphaea spp., (ii) marshes dominated by Cladium jamaicense and (iii) swamps dominated by dwarf Rhizophora mangle. At each site, GPS coordinates were recorded and sampling was then conducted using a $1-\mathrm{m}^{2}$ throw trap to delineate a $1-\mathrm{m}^{2}$ area which was treated as a sample plot (Kushlan, 1981). Periphyton mat samples were collected from four plots at each site. At each plot a photograph was taken to record the surface view, and water depth, $\mathrm{pH}$ and conductivity were recorded. Periphyton mat material was then collected by hand, placed onto a seine net and coarsely sorted to remove animals, plant material and marl. A subsample of 120 $\mathrm{ml}$ was removed from the periphyton material, placed in a sterile sample bag and stored in a cooler with ice for transport to the lab. When no observable calcitic periphyton mats were present, epipelon was sampled from the benthos and epiphytic films were scraped from any macrophytes present.

\section{$\underline{\text { Sample processing }}$}

In the laboratory, each sample was transferred to a clean 500-ml beaker to which an additional $20 \mathrm{ml}$ of distilled water was added to facilitate homogenizing. From the homogenized total volume, a 50-ml sub-sample was removed, poured into a labelled 120$\mathrm{ml}$ sample cup and placed in a drying oven at $80^{\circ} \mathrm{C}$ until completely dry. The dried contents were then ground using a mortar and pestle and analyzed for TP following the methods of Solórzano and Sharp (1980). An additional 10-ml sub-sample was removed and processed for quantitative diatom analysis, using the sulphuric acid oxidation method of Hasle and Fryxell (1970). A measured amount of cleaned/processed material was then 
pipetted unto a glass coverslip and permanently fixed to a glass slide using Naphrax ${ }^{\circledR}$ mounting medium.

\section{$\underline{\text { Taxonomic identification }}$}

A minimum of 500 diatom valves were counted along random transects on each slide at a magnification of X 1000, using a Nikon Eclipse E600 ® compound light microscope. Diatom species identification was done using standard available taxonomic reference sources, as well as reference materials archived at the Ruth Patrick Centre at the Philadelphia Academy of Sciences, Pennsylvania, U.S.A.

\section{Environmental information and community analyses}

Maximum, minimum and average values for water depth, $\mathrm{pH}$ and conductivity were calculated separately for wet and dry periods for each location. Prior to statistical analysis, periphyton mat TP (TP $\mu \mathrm{g} \mathrm{P}^{-1}$ dry mass) data were $\log 10$ transformed and diatom percentage abundance data were fourth root transformed to satisfy assumptions of normality (Clarke and Gorley, 2001).

Average per-site species richness and Shannon-Weiner diversity were calculated for each location, and differences within and among locations were tested for using ANOVA, followed by Tukey's test, using the SPSS ${ }^{\circledR}$ statistical package. The program C2 (Juggins, 2003) was used to determine TP optima and tolerance levels for diatom species present at all three locations and Indicator species analysis (done using the program PCORD 5 (); McCune and Grace, 2002) was conducted to identify species that effectively indicated either "high" or "low" TP concentrations. 


\section{RESULTS AND DISCUSSION}

\section{$\underline{\text { Habitat characterization }}$}

Habitat characteristics among the sampled locations overlapped, with most sites being dominated by Eleocharis spp. growing in shallow $(<1 \mathrm{~m})$ marl based soils, inundated by circumneutral waters. Among all three locations, average $\mathrm{pH}$ ranged from 7.2 to 9.2 and average conductivity ranged from 441.8 to $15,047.7 \mu \mathrm{S} \mathrm{cm}^{-1}$ (Table $3-2$ ). Some sites within two areas at the Mexico location (Mahahual and Marisma) were closer to the coast and supported a macrophytic assemblage dominated by Rhizophora mangle and Eleocharis spp. At these sites average $\mathrm{pH}$ and conductivity levels were greater than all other sites (Table 3-2), which is a result of the influx of brackish-water at these sites. During the dry period sampling session at the Belize location, the interior marsh areas were completely dry and inaccessible. Sampling was therefore limited to Eleocharis spp. marshes bordering the New River Lagoon, where, prior to the dry season, lagoonal waters with elevated TP could have advanced into these peripheral marshes.

\section{Diatom community analyses}

A total of 148 diatom species representing 39 genera were recorded from the three locations. Twenty eight of these species were found to be present at all three locations and the most common among these (with average abundances greater than $1 \%$ at all locations) included Brachysira neoexilis, Encyonema evergladianum, Encyonema spp., Fragilaria syngrotesca, Mastogloia smithii var. lacustris, Mastogloia smithii, Navicula cryptotenella, Nitzschia palaea and Nitzschia serpentiraphe (Table 3-3). 
Average, per-sample species richness at the Belize, Mexico and Jamaica locations was $18.5,18.7$ and 21.9 respectively, and the average per-sample species diversity at these locations was 1.66, 2.00 and 2.01 respectively (Table 3-4). The TP optima and tolerance levels were determined for the 28 species common to all locations and using the combined Caribbean dataset, 12 indicator species were identified, 3 of which were indicative of low mat TP concentrations (Encyonema evergladianum, Amphora sulcata and Nitzschia tubicola) and 9 of which indicated high mat TP concentrations (Achnanthidium neomicrocephalum, Eunotia flexuosa, Gomphonema cf. vibriodes, Eunotia camelus, Eunotia cf. karenae, Achnanthidium sp. 2, Achnanthidium exiguum, Synedra acus var. angustissima and Nitzschia scalaris) (Table 3-3).

\section{Annotated list of diatom taxa from Belize, Mexico and Jamaica sites}

Taxonomic information for each diatom identified in this study includes the genus and species name, as well as variety or form if known, and the recognized author. Published reference literature used for the identification of each taxon is provided, along with any taxonomic synonyms used in the reference material. Taxa for which no adequate reference could be found are described using diatom valve length, width and striae count of cells observed in the current study. Information regarding the average abundance of taxa at each location is given in Table 3-3, where designations of rare $(<1 \%)$, uncommon $(1$ to $<5 \%)$, common $(5$ to $<20 \%)$ and abundant $(>20 \%)$ are given. All photomicrographs presented in the following plates were taken at $1000 \mathrm{X}$ and the scale bar in the lower right corner of each plate represents $10 \mu \mathrm{m}$. Photomicrographs of very large diatoms were sized independent of the other photomicrographs on the same 
plate and a separate scale bar was included directly below the photomicrograph, again representing $10 \mu \mathrm{m}$.

Achnanthidium exiguum (Grunow) Czarnecki (Plate: 1 Figure: 5)

Synonyms: Achnanthes exigua Grunow var. exigua.

Literature: Krammer and Lange-Bertalot (2004), pp. 295 [Plate: 23; Figure: 6-7]; Novelo et al., (2007), pp. 97 [Plate: 4; Figure 3a-b].

Remarks: This species was identified as an indicator of high periphyton mat TP concentration.

Achnanthidium inflatum (Kützing) Hutton (Plate: 1 Figure: 1)

Synonyms: Achnanthes inflata (Kützing) Grunow

Literature: Krammer \& Lange-Bertalot (1991) pp. 253 [Plate: 2; Figure: 9 - 10];

Podzorski (1985) pp. 97 [Plate 4; Figure: 13 - 15]

Achnanthidium neomicrocephalum H. Lange-Bertalot \& F. Staab (Plate: 1 Figure: 2) Synonyms: Achnanthidium minutissimum (Kützing) Czarneki; Achnanthidium minutissimum var. gracillima (Meister) Lange- Bertalot; Achnanthes minutissima Kützing; Achnanthes microcephala (Kützing) Grunow

Literature: Krammer and Lange-Bertalot (2004), pp. 450 [Plate: 89; Figure: 1-10];

Novelo et al., (2007), pp. 97 [Plate: 4; Figure 4a -b, 5a-c]; Podzorski (1985) pp. 99 [Plate 5; Figure: $1-6]$ 
Remarks: This species exhibited a TP optimum and tolerance of $442 \mu \mathrm{g} \mathrm{P} \mathrm{g}^{-1}$ dry mass and $33 \mu \mathrm{g} \mathrm{P} \mathrm{g}^{-1}$ dry mass respectively and was identified as an indicator of high periphyton mat TP concentration.

Achnanthidium sp.1 (Plate: 1 Figure: 3)

Synonyms: Achnanthes marginulata Grunow

Literature: Podzorski (1985) pp. 97 [Plate 4; Figure: 19 - 21]

Remarks: Length: 10-17 $\mu \mathrm{m}$ Width: $2-4 \mu \mathrm{m}$ Striae: $36 / 10 \mu \mathrm{m}$.

Actinocyclus normanii (Gregory ex Greville) Hustedt (Plate: 12 Figure: 5)

Literature: Krammer \& Lange-Bertalot (1991) pp. 395 [Plate 82; Figure: 1]

Remarks: Width: 46-80 $\mu \mathrm{m}$ Punctae: 8-9/10 $\mu \mathrm{m}$ Extended rimoportulae: 10-14

Amphora cymbifera var. heritierarum Wachnicka \& Gaiser (Plate: 17 Figure: 10)

Literature: Wachnicka and Gasier, (2007) pp. 395 [Figure 7-8]

Amphora sulcata (Brébisson) Cleve (Plate: 17 Figure: 11)

Literature: Wachnicka and Gaiser (2007) pp. 420 [Figure 113 - 115]

Remarks: This species was identified as an indicator of low periphyton mat TP concentration.

Amphora sp.2 (Plate: 17 Figure: 3)

Remarks: Length: $70 \mu \mathrm{m}$ Width: $10 \mu \mathrm{m}$ Striae: 12/10 $\mu \mathrm{m}$. 
Amphora sp.3 (Plate: 17 Figure: 4)

Remarks: Length: $70 \mu \mathrm{m}$ Width: $20 \mu \mathrm{m}$ Striae: $9 / 10 \mu \mathrm{m}$.

Amphora copulata (Kützing) Schoeman \& Archibald (Plate: 17 Figure: 8)

Literature: Wachnicka \& Gaiser (2007) pp. 434 [Figure 172 - 173]

Amphora corpulenta var. capitata Tempere et Peragallo (Plate: 17 Figure: 9)

Literature: Wachnicka \& Gaiser (2007) pp. 409 [Figure 63]

Amphora pseudoproteus Wachnicka \& Gaiser (Plate: 17 Figure: 1, 2 and 7)

Literature: Wachnicka \& Gaiser (2007) pp. 434 [Figure 180 - 182]

Anomoneis sphaerophora (Ehrenberg) Pfitzer (Plate: 13 Figure: 1-2)

Literature: Metzeltin \& Lange-Bertalot (2007) pp.626 [Plate 178A; Figure: 2, 4];

Krammer \& Lange-Bertalot (1997) pp. 625 [Figure: 92: 1 - 2]; Podzorski (1985) pp. 97

[Plate 8; Figure: 3]

Aulacoseira ambigua (Grunow) Simonsen (Plate: 1 Figure: 17)

Literature: Krammer \& Lange-Bertalot (1991) pp. 273 [Plate 21: Figure 8 - 11]

Aulacoseira granulata (Ehrenberg) Simonsen (Plate: 1 Figure: 18)

Literature: Krammer \& Lange-Bertalot (1991) pp. 265 [Plate 17: Figure 4] 
Brachysira estonarium Witkowski, Lange-Bertalot \& Metzeltin (Plate: 1 Figure: 10)

Literature: Witkowski, Lange-Bertalot \& Metzeltin (2000) pp 711 [Plate: 134 Figure 1 3]

Remarks: Length: 21-34.5 $\mu \mathrm{m}$ Width: 4.5-5.5 $\mu \mathrm{m}$, Striae not discernable

Brachysira brebissonii Ross (Plate: 1 Figure: 9)

Literature: Lange-Bertalot \& Moser (1994) pp. 185 [Figure 1 - 18]

Brachysira cf. hofmanniae Lange-Bertalot (Plate: 2 Figure: 1)

Literature: Lange-Bertalot \& Moser (1994) pp. 119 [Figure 1 - 6]

Remarks: Length: 27-56 $\mu \mathrm{m}$ Width: 7.5-8.5 $\mu \mathrm{m}$, Striae not discernable

Brachysira neoexilis Lange-Bertalot (Plate: 1 Figure: 8)

Synonyms: Anomoeoneis vitrea (Grunow) Ross

Literature: Lange-Bertalot \& Moser (1994) pp. 117 [Figure 1 - 7]; pp. 119 [Figure 19 22]; Podzorski (1985) pp. 105 [Plate 8; Figure: 4 - 6]

Remarks: The occurrence of this species overlapped with that of Brachysira procera and Brachysira pumila at multiple sites. The gradation in the range of sizes and froms led to the consideration of these three taxa as morphs of the same species. They were therefore lumped during analyses and together displayed a TP optimum and tolerance of $273 \mu \mathrm{g} \mathrm{P}$ $\mathrm{g}^{-1}$ dry mass and $32 \mu \mathrm{g} \mathrm{P} \mathrm{g}^{-1}$ dry mass respectively. 
Brachysira procera Lange-Bertalot \& Moser (Plate: 2 Figure: 2)

Literature: Lange-Bertalot \& Moser (1994) pp. 117 [Figure 8 - 12; 20 - 24]

Remarks: The occurrence of this species overlapped with that of Brachysira neoexilis and Brachysira pumila at multiple sites. The gradation in the range of sizes and froms led to the consideration of these three taxa as morphs of the same species. They were therefore lumped during analyses and together displayed a TP optimum and tolerance of $273 \mu \mathrm{g}$ P $\mathrm{g}^{-1}$ dry mass and $32 \mu \mathrm{g} \mathrm{P} \mathrm{g}^{-1}$ dry mass respectively.

Brachysira pumila Metzeltin \& Lange-Bertalot (Plate: 1 Figure: 11)

Literature: Metzeltin \& Lange-Bertalot (1998) pp. 439 [Plate 102; Figure 13-17]

Remarks: The occurrence of this species overlapped with that of Brachysira procera and Brachysira neoexilis at multiple sites. The gradation in the range of sizes and froms led to the consideration of these three taxa as morphs of the same species. They were therefore lumped during analyses and together displayed a TP optimum and tolerance of $273 \mu \mathrm{g} \mathrm{P} \mathrm{g}^{-1}$ dry mass and $32 \mu \mathrm{g} \mathrm{g}^{-1}$ dry mass respectively.

Caloneis sp.1 (Plate: 4 Figure: 8)

Synonyms: Caloneis bacillum (Grunow) Cleve

Literature: Podzorski (1985) pp113 [Plate 12; Figure: 14]

Remarks: Length: 27-45 $\mu \mathrm{m}$ Width: 6-9 $\mu \mathrm{m}$ Striae: $28 / 10 \mu \mathrm{m}$ 
Caloneis sp.2 (Plate: 4 Figure: 10)

Synonyms: Caloneis bacillum (Grunow) Cleve

Literature: Podzorski (1985) pp113 [Plate 12; Figure: 15]

Remarks: Length: $39 \mu \mathrm{m}$ Width: $9 \mu \mathrm{m}$ Striae: $22 / 10 \mu \mathrm{m}$

Caloneis sp.3 (Plate: 4 Figure: 11)

Synonyms: Caloneis bacillum (Grunow) Cleve

Literature: Podzorski (1985) pp113 [Plate 12; Figure: 16]

Remarks: Length: $32 \mu \mathrm{m}$ Width: $8.5 \mu \mathrm{m}$ Striae: $21 / 10 \mu \mathrm{m}$

Caponea caribbea Podzorski (Plate: 4 Figure: 7)

Literature: Podzorski (1985) pp113 [Plate 12; Figure: 5 - 7]

Cocconeis placentula Ehrenberg

Literature: Podzorski (1985) pp 97 [Plate 4; Figure: 1 -3]

Craticula cuspidata (Kützing) Mann (Plate: 11 Figure: 3)

Literature: Metzeltin \& Lange-Bertalot (1998) pp. 427 [Plate 96; Figure 3]

Craticula sp.1 (Plate: 12 Figure: 2)

Remarks: Length: 225-228 $\mu \mathrm{m}$ Width: 50-51 $\mu \mathrm{m}$ Striae: 12-14/10 $\mu \mathrm{m}$ 
Cyclotella meneghiniana Kützing (Plate: 2 Figure: 4)

Literature: Tanaka (2007) pp 121 [Figure 1a-7b]

Remarks: This species displayed a TP optimum and tolerance of $289 \mu \mathrm{g} \mathrm{P} \mathrm{g}^{-1}$ dry mass and $29 \mu \mathrm{g} \mathrm{g} \mathrm{g}^{-1}$ dry mass respectively.

Cyclotella litoralis Lange \& Syvertsen (Plate: 2 Figure: 3 )

Literature: Tanaka (2007) pp 111 [Figure 1a-4b]

Remarks: Width: 23.5-31 $\mu \mathrm{m}$ Striae: 9/10 $\mu \mathrm{m}$ Punctae: 6-8

Cyclotella cf. atomus var. gracilis Genkil \& Kiss (Plate: 2 Figure: 5)

Literature: Tanaka (2007) pp 83 [Figure 1a - 3b]

Cyclotella sp.1 (Plate: 2 Figure: 6)

Remarks: Width: $4-5 \mu \mathrm{m}$ Striae: $14 / 5 \mu \mathrm{m}$

Cymbella aspera (Ehrenberg) Cleve (Plate: 10 Figure: 3)

Synonyms: Cymbella aspera (Ehrenberg) Peragallo

Literature: Krammer \& Lange-Bertalot (1997) pp. 705 [Figure 131: 2 -3] 
Diploneis oblongella (Naegeli ex Kuetzing) Ross (Plate: 7 Figure: 6)

Literature: Krammer \& Lange-Bertalot (1997) pp. 658 [Figure 108: 9 - 10]

Remarks: Length: 19-23 $\mu \mathrm{m}$ Width: $8 \mu \mathrm{m}$ Striae: 20/10 $\mu \mathrm{m}$.

This species displayed a TP optimum and tolerance of $225 \mu \mathrm{g} \mathrm{P} \mathrm{g}^{-1}$ dry mass and $27 \mu \mathrm{g} \mathrm{P}$ $\mathrm{g}^{-1}$ dry mass respectively.

Diploneis parma Cleve (Plate: 7 Figure: 2 and 5)

Remarks: Length: 24-42.5 $\mu \mathrm{m}$ Width: 17-21 $\mu \mathrm{m}$ Striae: $12-14 / 10 \mu \mathrm{m}$ Areolae: 16-18/10 $\mu \mathrm{m}$. This species exhibited a TP optimum and tolerance of $235 \mu \mathrm{g} \mathrm{P} \mathrm{g}^{-1}$ dry mass and 30 $\mu \mathrm{g} \mathrm{P} \mathrm{g}{ }^{-1}$ dry mass respectively.

Diploneis cf. elliptica var. tropica Frenguelli (Plate: 7 Figure: 1)

Literature: Metzeltin, D., H. Lange-Bertalot, and F. García Rodríguez (2005) pp. 471

[Plate 113; Figure 5 - 8]

Diploneis elliptica (Plate: 5 Figure: 6)

Literature: Krammer (1997) pp. 659 [Plate: 108; Figure: 14 - 15]

Remarks: Length: 37-65 $\mu \mathrm{m}$ Width: 24-29.5 $\mu \mathrm{m}$ Striae: 10-12/10 $\mu \mathrm{m}$ Areolae: 16/10

Diploneis sp.2 (Plate: 5 Figure: 7)

Diploneis sp.5 (Plate: 7 Figure: 3)

Remarks: Length: 43-46 $\mu \mathrm{m}$ Width: 19-22 $\mu \mathrm{m}$ Striae: 13-14/10 $\mu \mathrm{m}$ Areolae: 8-9/10 
Diploneis sp.6 (Plate: 7 Figure: 4)

Remarks: Length: $28-48 \mu \mathrm{m}$ Width: 17-23 $\mu \mathrm{m}$ Striae: 11-12/10 $\mu \mathrm{m}$

Diploneis cf. finnica (Plate: 16 Figure: 5)

Literature: Krammer \& Lange-Bertalot (1997) pp. 663 [Figure 110: 1 - 2]; Hustedt (1959)

pp. 561 [Figure: 1064]

Remarks: Length: 70-75 $\mu \mathrm{m}$ Width: 41-44 $\mu \mathrm{m}$ Striae: 8-9/10 $\mu \mathrm{m}$ Areolae: 16/10

Encyonema evergladianum Krammer (Plate: 4 Figure: 3)

Literature: Krammer (1997) pp. 333 [Plate: 142; Figure: 1 - 7]

Remarks: Length: $12-30 \mu \mathrm{m}$ Width: 4-5 $\mu \mathrm{m}$ Striae: 20-24/10 $\mu \mathrm{m}$. This species exhibited a TP optimum and tolerance of $229 \mu \mathrm{g} \mathrm{P} \mathrm{g}^{-1}$ dry mass and $28 \mu \mathrm{g} \mathrm{P} \mathrm{g}^{-1}$ dry mass respectively and was indicative of low periphyton mat TP concentration.

Encyonema jemtlandicum var. venezolanum Krammer (Plate: 14 Figure: 3-4)

Literature: Krammer (1997) pp. 208; pl. 14, fig. 1 -3

Encyonema silesiacum (Bleisch) Mann (Plate: 14 Figure: 2)

Literature: Krammer (1997) pp. 189 [Plate: 4; Figure: 11 - 18]

Encyonema sp.1 (Plate: 14 Figure: 5) 
Encyonema sp.2 (Plate: 14 Figure: 6)

Remarks: The occurrence of this species overlapped with that of Encyonema sp. 3 at multiple sites. The gradation in the range of sizes and froms led to the consideration of these two taxa as morphs of the same species. They were therefore lumped during analyses and together displayed a TP optimum and tolerance of $230 \mu \mathrm{g} \mathrm{P} \mathrm{g}^{-1}$ dry mass and $27 \mu \mathrm{g} \mathrm{P} \mathrm{g}^{-1}$ dry mass respectively.

Encyonema sp.3 (Plate: 14 Figure: 7)

Remarks: The occurrence of this species overlapped with that of Encyonema sp. 3 at multiple sites. The gradation in the range of sizes and froms led to the consideration of these two taxa as morphs of the same species. They were therefore lumped during analyses and together displayed a TP optimum and tolerance of $230 \mu \mathrm{g} \mathrm{P} \mathrm{g}^{-1}$ dry mass and $27 \mu \mathrm{g} \mathrm{P} \mathrm{g}^{-1}$ dry mass respectively.

Encyonema vulgare var. vulgare Krammer (Plate: 14 Figure: 1)

Literature: Krammer (1997) pp. 259 [Plate: 39; Figure: 3 - 4]

Encyonopsis microcephala (Grunow) Krammer (Plate: 4 Figure: 5)

Literature: Krammer (1997) pp. 335 [Plate: 143; Figure: 14 - 18]

Remarks: Length: 15.5-22 $\mu \mathrm{m}$ Width: 4-4.5 $\mu \mathrm{m}$ Striae: 26-32/10 $\mu \mathrm{m}$. This species exhibited a TP optimum and tolerance of $334 \mu \mathrm{g} \mathrm{P} \mathrm{g}^{-1}$ dry mass and $25 \mu \mathrm{g} \mathrm{P} \mathrm{g}^{-1}$ dry mass respectively. 
Encyonopsis subminuta Krammer et Reichardt (Plate: 4 Figure: 14)

Literature: Krammer (1997) pp. 339 [Plate: 144; Figure: 6 - 9]

Remarks: Length: $27 \mu \mathrm{m}$ Width: $4 \mu \mathrm{m}$ Striae: $26 / 10 \mu \mathrm{m}$.

Epithemia sp.1 (Plate: 16 Figure: 4)

Eunotia camelus Ehrenberg (Plate: 15 Figure: 9)

Literature: Metzeltin \& Lange-Bertalot (1998) pp.293 [Plate: 29; Figure: 1 - 11]

Remarks: This species was identified as an indicator of high periphyton mat TP concentration.

Eunotia cf. karenae Metzeltin \& Lange-Bertalot (Plate: 15 Figure: 2)

Literature: Metzeltin \& Lange-Bertalot (2007) pp. 105 [Plate: 48; Figure: 1 - 4]

Remarks: Length: 121-192 $\mu \mathrm{m}$ Width: 6-7 $\mu \mathrm{m}$ Striae: 10-12/10 $\mu \mathrm{m}$ Areolae: 28/10 $\mu \mathrm{m}$.

This species was indicative of high periphyton mat TP concentration.

Eunotia cf. yberai Frenguelli (Plate: 15 Figure: 12)

Literature: Metzeltin, Lange-Bertalot \& García Rodríguez (2005) pp.289 [Plate: 22;

Figure 1-4] 
Eunotia flexuosa (Brébisson) Kützing (Plate: 15 Figure: 5)

Literature: Krammer \& Lange-Bertalot (1991) pp. 511 [Plate: 140; Figure: 9]

Remarks: This species exhibited a TP optimum and tolerance of $368 \mu \mathrm{g} \mathrm{P} \mathrm{g}^{-1}$ dry mass

and $25 \mu \mathrm{g} \mathrm{P} \mathrm{g}^{-1}$ dry mass respectively and was indicative of high periphyton mat TP concentration.

Eunotia implicata Nörpel, Lange-Bertalot \& Alles (Plate: 15 Figure: 7)

Literature: Krammer \& Lange-Bertalot (1991) pp. 517 [Plate: 143; Figure: 1 - 9]

Eunotia cf. monodon Ehrenberg (Plate: 15 Figure: 3)

Literature: Metzeltin, Lange-Bertalot \& García Rodríguez (2005) pp.291 [Plate: 23;

Figure 4 - 5]; Krammer \& Lange-Bertalot (1991) pp. 547 [Plate: 158; Figure: 2]

Eunotia naegelii Migula (Plate: 15 Figure: 4)

Literature: Krammer \& Lange-Bertalot (1991) pp. 511 [Plate: 140; Figure: 1 - 3]

Eunotia rabenhorstiana var. elongata (Patrick) Metzeltin \& Lange-Bertalot (Plate: 15

Figure: 1)

Literature: Metzeltin \& Lange-Bertalot (1998) pp. 363 [Plate: 64; Figure: 11]

Eunotia botuliformis Wild, Norpel \& Lange-Bertalot (Plate: 15 Figure: 11)

Literature: Lange-Bertalot (1993) pp. 230 [Plate: 33; Figure: 2 - 4; 11 - 15] 
Eunotia sp.1 (Plate: 15 Figure: 6)

Eunotia sp.2 (Plate: 15 Figure: 8)

Eunotia sp.3 (Plate: 15 Figure: 10)

Fallacia pygmaea (Kützing) Stickle \& Mann (Plate: 8 Figure: 5)

Synonyms: Navicula pygmaea

Literature: Metzeltin \& Lange-Bertalot (1998) pp. 419 [Plate: 92; Figure: 9 - 11];

Podzorski (1985) pp107 [Plate 9; Figure: 6]

Fragilaria (?) sp.1 cf. famelica (Kützing) Lange-Bertalot (Plate: 5 Figure: 3)

Literature: Lange-Bertalot (1993) pp. 189 [Plate: 12; Figure: 13]; Krammer \& Lange-

Bertalot (1991) pp. 453 [Plate: 111; Figure: 6]

Remarks: Length: 44-71 $\mu \mathrm{m}$ Width: 2-2.5 $\mu \mathrm{m}$ Striae: 15-20/10 $\mu \mathrm{m}$. This species

exhibited a TP optimum and tolerance of $263 \mu \mathrm{g} \mathrm{P} \mathrm{g}^{-1}$ dry mass and $29 \mu \mathrm{g} \mathrm{P} \mathrm{g}^{-1}$ dry mass respectively.

Fragilaria capucina var. vaucheriae (Kützing) Lange-Bertalot (Plate: 5 Figure: 4)

Literature: Krammer \& Lange-Bertalot (1991) pp. 447 [Plate: 108; Figure: 10 - 15] 
Fragilaria synegrotesca Lange-Bertalot (Plate: 5 Figure: 2)

Synonyms: Fragilaria vaucheriae (Kützing) Petersen

Literature: Lange-Bertalot (1993) pp. 189 [Plate: 12; Figure: 3 - 7]; Podzorski (1985) pp.

91 [Plate: 1; Figure: 13]

Remarks: This species exhibited a TP optimum and tolerance of $266 \mu \mathrm{g} \mathrm{P} \mathrm{g}^{-1}$ dry mass and $29 \mu \mathrm{g} \mathrm{g} \mathrm{g}^{-1}$ dry mass respectively.

Fragilaria cf. ulna (Nitzsch) Lange-Bertalot (Plate: 16 Figure: 2)

Remarks: Length: $180 \mu \mathrm{m}$ Width: $4 \mu \mathrm{m}$ Striae: $10 / 10 \mu \mathrm{m}$

Fragilaria ulna var. ulna (Nitzsch) Lange-Bertalot (Plate: 16 Figure: 1)

Literature: Krammer \& Lange-Bertalot (1991) pp. 475 [Plate: 122; Figure: 1]

Remarks: This species exhibited a TP optimum and tolerance of $281 \mu \mathrm{g} \mathrm{P} \mathrm{g}^{-1}$ dry mass and $31 \mu \mathrm{g} \mathrm{g} \mathrm{g}^{-1}$ dry mass respectively.

Frustulia rhomboides var. crassinervia (Brebisson ex. W. Smith) Ross (Plate: 3 Figure: 3)

Literature: Krammer \& Lange-Bertalot (1997) pp. 631 [Figure: 6 - 7]

Gomphonema affine Kützing (Plate: 8 Figure: 4)

Literature: Tobias \& Gaiser (2006) pp. 390 [Figure: 10 - 14] 
Gomphonema gracile Ehrenberg (Plate: 8 Figure: 3 )

Literature: Tobias \& Gaiser (2006) pp. 396 [Figure: 48 - 50]

Gomphonema intricatum var. vibrio (Ehrenberg) Cleve (Plate: 8 Figure: 2)

Synonyms: Gomphonema intricatum var. vibrio Ehrenberg sensu Fricke

Literature: Tobias \& Gaiser (2006) pp. 396 [Figure: 51 - 62]

Remarks: This species exhibited a TP optimum and tolerance of $329 \mu \mathrm{g} \mathrm{P} \mathrm{g}^{-1}$ dry mass

and $32 \mu \mathrm{g} \mathrm{P} \mathrm{g}^{-1}$ dry mass respectively.

Gomphonema parvulum (Kützing) Grunow (Plate: 8 Figure: 10)

Literature: Tobias \& Gaiser (2006) pp. 400 [Figure: 67 - 68]

Gomphonema cf. vibriodes Reichardt \& Lange-Bertalot (Plate: 8 Figure: 1)

Literature: Tobias \& Gaiser (2006) pp. 392 [Figure: 38 - 42]

Remarks: This species exhibited a TP optimum and tolerance of $406 \mu \mathrm{g} \mathrm{P} \mathrm{g}$ dry mass

and $32 \mu \mathrm{g} \mathrm{P} \mathrm{g}^{-1}$ dry mass respectively and was indicative of high periphyton mat TP concentration.

Hantzschia cf. elongata (Hantzsch) Grunow (Plate: 10 Figure: 2)

Literature: Hustedt (1959) pp. 848 [Figure: 751]; Lange-Bertalot (1993) pp. 385 [Plate:

109; Figure: 1 - 3]; Krammer \& Lange-Bertalot (1997) pp. 395 [Plate: 89; Figure: 1 - 2] 
Hantzschia spectabilis (Ehrenberg) Hustedt (Plate: 10 Figure: 5)

Literature: Krammer \& Lange-Bertalot (1997) pp. 399 [Plate: 91; Figure: 1 - 3]

Hantzschia cf. vivacior Lange-Bertalot (Plate: 10 Figure: 4)

Literature: Lange-Bertalot (1993) pp. 374 [Plate: 104; Figure: 1 - 6]

Mastogloia braunii Grunow (Plate: 13 Figure: 4 and 7)

Literature: Krammer \& Lange-Bertalot (1997) pp. 845 [Figure: 200:1 - 3]

Mastogloia cf. smithii Thwaites ex. W. Smith (Plate: 8 Figure: 9)

Literature: Literature: Krammer \& Lange-Bertalot (1997) pp. 847 [Figure: 201: 3 - 5]

Remarks: This species exhibited a TP optimum and tolerance of $240 \mu \mathrm{g} \mathrm{P} \mathrm{g}^{-1}$ dry mass and $29 \mu \mathrm{g} \mathrm{P} \mathrm{g}^{-1}$ dry mass respectively.

Mastogloia smithii var. lacustris Grunow (Plate: 8 Figure: 8)

Literature: Literature: Krammer \& Lange-Bertalot (1997) pp. 847 [Figure: 201:1]

Remarks: This species exhibited a TP optimum and tolerance of $239 \mu \mathrm{g} \mathrm{P} \mathrm{g}^{-1}$ dry mass and $26 \mu \mathrm{g} \mathrm{P} \mathrm{g}^{-1}$ dry mass respectively and was indicative of low periphyton mat TP concentration.

Mastogloia lanceolata Thwaites ex. Smith (Plate: 13 Figure: 6)

Literature: Podzorski (1985) pp. 99 [Plate: 5; Figure: 19 - 20] 
Mastogloia elliptica (Agardh) Cleve (Plate: 13 Figure: 9)

Literature: Krammer \& Lange-Bertalot (1997) pp. 847 [Figure: 201: 10 - 13]

Mastogloia elliptica var. dansei (Thwaites) Cleve (Plate: 13 Figure: 5)

Literature: Krammer \& Lange-Bertalot (1997) pp. 849 [Figure: 202: 1 - 2]

Navicella pusilla (Grunow) Krammer (Plate: 3 Figure: 2)

Synonym: Cymbella pusilla Grunow

Literature: Krammer \& Lange-Bertalot (1997) pp. 738 [Figure: 148: 1 - 9]

Navicula brasiliana (Cleve) Cleve (Plate: 13 Figure: 3 )

Synonym: Naviculadicta brasiliana (Cleve) Lange-Bertalot

Literature: Krammer \& Lange-Bertalot (1997) pp. 545 [Figure: 52: 1 - 2]; Metzeltin \& Lange-Bertalot (1998) pp. 421 [Plate: 93; Figure: 6 - 7]

Navicula cf. radiosa Kützing (Plate: 3 Figure: 1)

Synonyms: Navicula lanceolata (Agardh)

Literature: Krammer \& Lange-Bertalot (1997) pp. 499 [Figure: 29: 1 - 2]; Podzorski (1985) pp. 115 [Plate: 13; Figure: 19]; Podzorski (1985) pp. 115 [Plate: 13; Figure: 13] Remarks: Length: 46-71 $\mu \mathrm{m}$ Width: 7-9 $\mu \mathrm{m}$ Striae: $14 / 10 \mu \mathrm{m}$. This species exhibited a TP optimum and tolerance of $282 \mu \mathrm{g} \mathrm{P} \mathrm{g}^{-1}$ dry mass and $35 \mu \mathrm{g} \mathrm{P} \mathrm{g}^{-1}$ dry mass respectively and was indicative of low periphyton mat TP concentration. 
Navicula constans Hustedt (Plate: 4 Figure: 12)

Literature: Krammer \& Lange-Bertalot (1997) pp. 536 [Figure: 48: 10 - 11]

Navicula cryptotenella Lange-Bertalot (Plate: 3 Figure: 4)

Literature: Krammer \& Lange-Bertalot (1997) pp. 507 [Figure: 33: 9 - 11]

Remarks: This species exhibited a TP optimum and tolerance of $332 \mu \mathrm{g} \mathrm{P} \mathrm{g}{ }^{-1}$ dry mass and $30 \mu \mathrm{g} \mathrm{g} \mathrm{g}^{-1}$ dry mass respectively and was indicative of low periphyton mat TP concentration.

Navicula palestinae Gerloff, Natour \& Rivera (Plate: 8 Figure: 7)

Navicula pseudocrassirostris Hustedt (Plate: 8 Figure: 6)

Navicula stroemii Hustedt (Plate: 1 Figure: 14)

Literature: Krammer \& Lange-Bertalot (1997) pp. 579 [Figure: 69: 1 - 3]

Navicula subtilissima Cleve (Plate: 4 Figure: 13)

Literature: Krammer \& Lange-Bertalot (1997) pp. 599 [Figure: 79: 22]

Remarks: This species exhibited a TP optimum and tolerance of $291 \mu \mathrm{g} \mathrm{P} \mathrm{g}^{-1}$ dry mass and $35 \mu \mathrm{g} \mathrm{P} \mathrm{g}^{-1}$ dry mass respectively and was indicative of low periphyton mat $\mathrm{TP}$ concentration. 
Neidium ampliatum (Ehrenberg) Krammer (Plate: 4 Figure: 1-2)

Literature: Krammer \& Lange-Bertalot (1997) pp. 653 [Figure: 105: 5]

Nitzschia acicularis (Plate: 10 Figure: 6)

Literature: Krammer \& Lange-Bertalot (1997) pp. 386 [Plate: 85; Figure: 1 - 3]

Nitzschia amphibia (Grunow) Lange-Bertalot (Plate: 6 Figure: 11)

Literature: Krammer \& Lange-Bertalot (1997) pp. 372 [Plate: 78; Figure: 15]

Nitzschia denticula Grunow (Plate: 6 Figure: 9)

Synonyms: Denticula kuetzingii Grunow

Literature: Lange-Bertalot (1993) pp. 407 [Plate: 120; Figure: 1 - 2]

Nitzschia lacunarum Hustedt (Plate: 10 Figure: 7)

Literature: Krammer \& Lange-Bertalot (1997) pp. 324 [Plate: 54; Figure: 4]

Nitzschia microcephala Grunow (Plate: 6 Figure: 7)

Literature: Krammer \& Lange-Bertalot (1997) pp. 382 [Plate: 83; Figure: 16]

Remarks: Length: 13.5-16.5 $\mu \mathrm{m}$ Width: 3-4 $\mu \mathrm{m}$ Striae: 13-14/10 $\mu \mathrm{m}$.

Nitzschia nana Grunow (Plate: 10 Figure: 9)

Literature: Krammer \& Lange-Bertalot (1997) pp. 250 [Plate: 17; Figure: 5,7] 
Nitzschia palaea (Kutzing) Smith (Plate: 6 Figure: 5-6)

Literature: Krammer \& Lange-Bertalot (1997) pp. 334 [Plate: 59; Figure: 3]

Remarks: This species exhibited a TP optimum and tolerance of $222 \mu \mathrm{g} \mathrm{P} \mathrm{g}^{-1}$ dry mass and $24 \mu \mathrm{g} \mathrm{g} \mathrm{g}^{-1}$ dry mass respectively.

Nitzschia scalaris (Ehrenberg) Smith (Plate: 6 Figure: 1)

Literature: Krammer \& Lange-Bertalot (1997) pp. 266 [Plate: 25; Figure: 1 - 4]

Remarks: This species was indicative of high periphyton mat TP concentration.

Nitzschia semirobusta Lange-Bertalot (Plate: 6 Figure: 10)

Literature: Lange-Bertalot (1993) pp. 407 [Plate: 120; Figure: 3 - 19]

Nitzschia serpentiraphe Lange-Bertalot (Plate: 6 Figure: 2)

Literature: Lange-Bertalot (1993) pp. 419 [Plate: 126; Figure: 1-7]

Remarks: This species exhibited a TP optimum and tolerance of $180 \mu \mathrm{g} \mathrm{P} \mathrm{g}^{-1}$ dry mass

and $18 \mu \mathrm{g} \mathrm{g} \mathrm{g}^{-1}$ dry mass respectively and was indicative of low periphyton mat TP concentration.

Nitzschia sp.1 (Plate: 6 Figure: 8)

Remarks: Length: $21 \mu \mathrm{m}$ Width: $2 \mu \mathrm{m}$ Striae: $13 / 5 \mu \mathrm{m}$

Nitzschia thermalis var. minor Hilse (Plate: 10 Figure: 10)

Literature: Hustedt (1959) pp. 857 [Figure: 772] 
Nitzschia obtusa var. kurzii Rabenhorst ex Cleve \& Moller (Plate: 17 Figure: 6)

Synonym: Nitzschia obtusa var. lata Hagelstein

Literature: Krammer \& Lange-Bertalot (1997) pp. 251 [Plate: 17; Figure: 3]; Podzorski (1985) pp 137 [Plate 24; Figure: 1]

Nitzschia linearis var. subtilis (Grunow) Hustedt (Plate: 6 Figure: 3-4)

Synonym: Nitzschia subtilis Grunow

Literature: Krammer \& Lange-Bertalot (1997) pp. 327 [Plate: 55; Figure: 8]; Podzorski (1985) pp 138 [Plate 25; Figure: 15]

Remarks: This species was indicative of low periphyton mat TP concentration.

Parlibellus sp.1 (Plate: 12 Figure: 2)

Pinnularia acrosphaeria (Brébisson) W. Smith (Plate: 9 Figure: 10)

Literature: Krammer \& Lange-Bertalot (1997) pp. 807 [Figure: 181:3]

Pinnularia cf. neomajor var. inflata Krammer (Plate: 9 Figure: 1)

Literature: Metzeltin \& Lange-Bertalot (2007) pp. 721 [Plate: 225; Figure: 4]; Krammer (2000) pp 602 [Plate 171; Figure: 2]

Remarks: Length: $181 \mu \mathrm{m}$ Width: $27 \mu \mathrm{m}$ Striae: $8 / 10 \mu \mathrm{m}$

Pinnularia sp.1 (Plate: 9 Figure: 3)

Remarks: Length: $121 \mu \mathrm{m}$ Width: $16 \mu \mathrm{m}$ Striae: $8 / 10 \mu \mathrm{m}$ 
Pinnularia sp.2 (Plate: 9 Figure: 5)

Remarks: Length: $117 \mu \mathrm{m}$ Width: $26 \mu \mathrm{m}$ Striae: $9 / 10 \mu \mathrm{m}$

Pinnularia sp.4 (Plate: 9 Figure: 2)

Literature: Metzeltin \& Lange-Bertalot (2007) pp. 721 [Plate: 225; Figure: 4]; Krammer (2000) pp 602 [Plate 171; Figure: 2]

Remarks: Length: $131 \mu \mathrm{m}$ Width: $24 \mu \mathrm{m}$ Striae: $8 / 10 \mu \mathrm{m}$

Pinnularia sp.5 (Plate: 9 Figure: 9)

Remarks: Length: $70 \mu \mathrm{m}$ Width: $9 \mu \mathrm{m}$ Striae: 10/10 $\mu \mathrm{m}$

Pinnularia sp.7 (Plate: 9 Figure: 12)

Remarks: Length: 70-98 $\mu \mathrm{m}$ Width: 13-15 $\mu \mathrm{m}$ Striae: 8-9/10 $\mu \mathrm{m}$

Pinnularia tropica Hustedt (Plate: 9 Figure: 4)

Literature: Foged (1984) pp.145 [Plate: 11; Figure: 2]

Remarks: Length: $109 \mu \mathrm{m}$ Width: $20 \mu \mathrm{m}$ Striae: 7/10 $\mu \mathrm{m}$

Pinnularia divergens Smith (Plate: 9 Figure: 7)

Literature: Krammer \& Lange-Bertalot (1997) pp. 803 [Figure:179: 4]

Remarks: Length: $85 \mu \mathrm{m}$ Width: $12 \mu \mathrm{m}$ Striae: 10/10 $\mu \mathrm{m}$ 
Pinnularia microstauron (Ehrenberg) Cleve (Plate: 9 Figure: 8)

Literature: Metzeltin \& Lange-Bertalot (2007) pp. 797 [Plate: 263; Figure: 10, Plate: 264;

Figure: 8-9]

Remarks: Length: 72-80 $\mu \mathrm{m}$ Width: 10-12 $\mu \mathrm{m}$ Striae: $8 / 10 \mu \mathrm{m}$

Pinnularia stoermeri Metzeltin \& Lange-Bertalot (Plate: 9 Figure: 11, 6)

Literature: Metzeltin \& Lange-Bertalot (2007) pp. 753 [Plate: 241; Figure: 2-3]

Remarks: Length: 80-118 $\mu \mathrm{m}$ Width: 18-24 $\mu \mathrm{m}$ Striae: 7/10 $\mu \mathrm{m}$

Pinnularia pisciculus var. angusta Metzeltin \& Krammer (Plate: 9 Figure: 13)

Synonyms: Pinnularia braunii Metzeltin \& Krammer

Literature: Krammer \& Lange-Bertalot (1997) pp. 819 [Figure: 187: 3]; Metzeltin \&

Lange-Bertalot (2007) pp. 817 [Plate: 273; Figure: 8]

Remarks: Length: $43 \mu \mathrm{m}$ Width: $8 \mu \mathrm{m}$ Striae: $10 / 10 \mu \mathrm{m}$

Plagiotropis sp.1 (Plate: 12 Figure: 1)

Remarks: Length: 142-153 $\mu \mathrm{m}$ Width: 21-23 $\mu \mathrm{m}$, Striae: 17/10 $\mu \mathrm{m}$.

Planothidium frequentisimum (Plate: 1 Figure: 7)

Synonyms: Achnanthes lanceolata var. dubia Grunow

Literature: Podzorski (1985) pp. 97 [Plate 4; Figure: 16 - 17]

Pleurosigma sp.1 (Plate: 11 Figure: 1) 
Proschkinia sp.1 (Plate: 4 Figure: 6)

Remarks: Length: 25-26 $\mu \mathrm{m}$ Width: 3.5-5 $\mu \mathrm{m}$, Striae not discernable

Rhopalodia gibba (Ehrenberg) Muller (Plate: 12 Figure: 4)

Literature: Krammer \& Lange-Bertalot (1997) pp. 439 [Plate: 111; Figure: 2,6];

Podzorski (1985) pp 131 [Plate 21; Figure: 11]

Sellaphora laevissima (Kützing) Krammer (Plate: 1 Figure: 13)

Synonyms: Navicula laevissima (Kützing)

Literature: Krammer \& Lange-Bertalot (1997) pp. 575 [Figure: 67: 8 -10]

Remarks: This species exhibited a TP optimum and tolerance of $321 \mu \mathrm{g} \mathrm{P} \mathrm{g}^{-1}$ dry mass and $33 \mu \mathrm{g} \mathrm{g} \mathrm{g}^{-1}$ dry mass respectively.

Sellaphora pupula (Kützing) Mereschkowsky (Plate: 13 Figure: 8)

Synonyms: Navicula pupula (Kützing)

Literature: Krammer \& Lange-Bertalot (1997) pp. 575 [Figure: 67: 1 - 2]

Sellaphora rioplatensis Metzeltin, Lange-Bertalot \& García-Rodríguez (Plate: 1 Figure: 16)

Sellaphora sp.1 (Plate: 1 Figure: 15)

Remarks: Length: 12-16 $\mu \mathrm{m}$ Width: 5-6 $\mu \mathrm{m}$ Striae: 12-14/5 $\mu \mathrm{m}$ 
Seminavis eulensteinii (Grunow) Danielidis, Ford \& Kennett (Plate: 17 Figure: 5)

Literature: Wachnicka and Gaiser (2007) pp.437 [Figure. 191-192, 195-197].

Stauroneis pachycephala Cleve (Plate: 4 Figure: 4)

Literature: Metzeltin \& Lange-Bertalot (2007) pp. 547 [Plate: 139; Figure: 44 - 45];

Podzorski (1985) pp. 105 [Plate: 8; Figure: 2]

Stauroneis phoenicentron (Nitzsch) Ehrenberg (Plate: 11 Figure: 3)

Literature: Podzorski (1985) pp. 97 [Plate 7; Figure: 4]

Remarks: Length: 212-242 $\mu \mathrm{m}$ Width: 39-45 $\mu \mathrm{m}$ Striae: 11/10 $\mu \mathrm{m}$ Areolae: 16/10 $\mu \mathrm{m}$.

Stauroneis cf. smithii var. incisa Pantocsek (Plate: 1 Figure: 12)

Literature: Siver, Hamilton, Stachura-Suchoples \& Kociolek (2005) pp.385 [Plate 68;

Figure: 3]

Remarks: Length: 22-27 $\mu \mathrm{m}$ Width: 7-8 $\mu \mathrm{m}$ Striae: $24 / 10 \mu \mathrm{m}$. Similar to $S$. smithii var. incisa, but striae density is lower; $24 / 10 \mu \mathrm{m}$ instead of $28-31 / \mu \mathrm{m}$.

Staurosira construens Ehrenberg (Plate: 5 Figure: 5)

Synonyms: Fragilaria construens Ehrenberg

Literature: Krammer \& Lange-Bertalot (1997) pp. 489 [Plate: 129; Figure: 22 - 23]

Staurosirella pinnata var. pinnata (Ehrenberg) Williams \& Round 
Stenopterobia curvula (Smith) Krammer (Plate: 10 Figure: 8)

Literature: Krammer \& Lange-Bertalot (1997) pp. 563 [Plate: 171; Figure: 6,7]

Surrirella elegans f. elongata Skvortzow (Plate: 10 Figure: 1)

Literature: Krammer \& Lange-Bertalot (1997) pp. 545 [Plate: 162; Figure: 6]

Synedra acus var. angustissima (Grunow) Van Heurck (Plate: 16 Figure: 3)

Literature: Krammer \& Lange-Bertalot (1991) pp. 459 [Plate: 114; Figure: 21];

Siver, Hamilton, Stachura-Suchoples \& Kociolek (2005) pp. 287 [Plate: 20; Figure: 5]

Remarks: This species was identified as an indicator of low periphyton mat TP concentration.

Tabularia tabulata (Agardh) Snoeijs (Plate: 5 Figure: 1)

Synonyms: Fragilaria fasciculata (Agardh) Lange-Bertalot; Synedra fasciculata var. truncata (Greville) Patrick

Literature: Krammer \& Lange-Bertalot (1991) pp. 501 [Plate: 135; Figure: 5]; Podzorski (1985) pp. 91 [Plate: 1; Figure: 17]

Unknown sp.1 (Plate: 1 Figure: 4)

Remarks: Length: $27 \mu \mathrm{m}$ Width: $5.5 \mu \mathrm{m}$ Striae: $33 / 10 \mu \mathrm{m}$

Unknown sp.2 (Plate: 1 Figure: 6)

Remarks: Length: $10 \mu \mathrm{m}$ Width: $5.5 \mu \mathrm{m}$ Striae: $13 / 5 \mu \mathrm{m}$ 


\section{ACKNOWLEDGMENTS}

The author would like to thank the Sian Ka'an Biosphere Reserve in Quintana Roo, Mexico and Lamanai Outpost in Orange Walk, Belize for facilitating site access and supporting this research. I also thank Clifton Ruehl, Raul Urgelles and collaborators from Universidad Nacional Autónoma de México for their assistance with the collection of field data from Mexico and Belize. I am also indebted to Dr. Marina Potapova of the Diatom Herbarium at the Ruth Patrick Center in the Philadelphia Academy of Sciences, Pensylvania, U.S.A, for her assistance with diatom identifications. This research was funded by the National Science Foundation under Grant No. DBI-0620409 and DEB9910514, as well as a grant to J. La Hée from the Latin American Caribbean Center at Florida International University. The Southeast Environmental Research Center (SERC) at FIU also provided funding for this research. This is publication number $\mathrm{xxx}$ from SERC and xxx from the Tropical Biology Program of the Department of Biological Sciences at FIU. 


\section{LITERATURE CITED}

Azan, S. and Webber, D. 2007. The characterization and classification of the Black River Upper Morass, Jamaica, using the three-parameter test of vegetation, soils and hydrology. Aquatic Conservation: Marine and Freshwater Ecosystems 17:5-23

Azim, M. E. and T. Asaeda. 2005. Periphyton structure, diversity and colonization. Pages. 15-33. in M. E. Azim, M. C. J. Verdegem, A. A. van Dam, M. C. M. Beveridge. (editors). Periphyton: ecology, exploitation and management. CABI Publishing, Oxfordshire, UK.

Browder JA, PJ Gleason, DR Swift. 1994 Periphyton in the Everglades: spatial variation, environmental correlates, and ecological implications. In: Davis SM, Ogden JC (eds) Everglades: The Ecosystem and its Restoration. St. Lucie Press, Delray Beach, Florida, pp 379-418

Browder, J.A., Cottrell, D., Brown, M., Newman, M., Edwards, R., Yuska, J., Browder, M., Krakoski, J., 1982. Biomass and Primary Production of Microphytes and Macrophytes in Periphyton Habitats of the Southern Everglades. Report T-662, South Florida Research Center, Homestead, Florida.

Cairns CE, Villanueva-Gutiérrez R, Koptur S, Bray DB. 2005 Bee populations, forest disturbance, and africanization in Mexico. Biotropica 37:686-692

Cooper, S.R., Huvane, J., Vaithiyanathan, P., Richardson, C.J., 1999. Calibration of diatoms along a nutrient gradient in Florida Everglades Water Conservation Area-2A, USA. Journal of Paleolimnology 22, 413-437.

Cronberg G. 1982. Plankton of the Negril and Black River Morasses, Jamaica. Report to the PCJ Kingston, Jamaica.

Davis M, Lalor GC, Rattray R (1998) Nutrient status of the Black River System, St.

Elizabeth, Jamaica. Jamaican Journal of Science and Technology 9:45-62 
Donar CM, Condon KW, Gantar M, Gaiser EE (2004) A new technique for examining the physical structure of Everglades floating periphyton mat. Nova Hedwigia 78:107-19

Enell M (1984) Water Chemistry of the Negril and Black River Morasses, Jamaica. Petroleum Corporation of Jamaica, Kingston, Jamiaca.

Ewe, S.M.L., Gaiser, E.E., Childers, D.L., Rivera-Monroy, V.H., Iwaniec, D., Fourquerean, J., Twilley, R.R., 2006. Spatial and temporal patterns of aboveground net primary productivity (ANPP) in the Florida Coastal Everglades LTER (2001-2004). Hydrobiologia 569, 459-474.

Foged, N. 1984. Freshwater and littoral diatoms from Cuba. Bibliotheca diatomologica, Band 5. J. Cramer, Stuttgart. 243 pp.

Gaiser EE, Scinto LJ, Richards JH, Jayachandrana K, Childers DL, Trexler JC, Jones RD (2004) Phosphorus in periphyton mats provides the best metric for detecting low-level P enrichment in an oligotrophic wetland. Water Research 38:507-516

Gaiser EE, Trexler JC, Richards JH, Childers DL, Lee D, Edwards AL, Scinto LJ, Jayachandran K, Noe GB, Jones RD (2005) Cascading ecological effects of low-level phosphorus enrichment in the Florida Everglades. Journal of Environmental Quality 34:717-723

Gaiser EE, Richards JH, Trexler JC, Jones RD, Childers DL (2006) Periphyton responses to eutrophication in the Florida Everglades: cross-system patterns of structural and compositional change. Limnology and Oceanograohy 51:617-630

Gaiser EE (2009) Periphyton as an indicator of restoration in the Florida Everglades. Ecological Indicators 9: S37-S45

Gaiser, E. E., La Hée, J. M., Tobias, F. A. C., Wachnicka, A. H. 2010. Mastogloia smithii var. lacustris Grun.: A structural engineer of calcareous mats in karstic subtropical wetlands. Proceedings of the Academy of Natural Sciences of Philadelphia (in press) 
Goldsborough LG, Robinson GGC (1996) Pattern in wetlands. In: Stevenson RJ, Bothwell ML, Lowe RL (eds.) Algal Ecology in Freshwater Benthic Ecosystems. Academic Press, pp 77-117

Grimshaw HJ, Rosen M, Swift DR, Rodberg K, Noel JM (1993) Marsh phosphorus concentrations, phosphorus content and species composition of Everglades periphyton communities. Archiv für Hydrobiologie 128:257-276

Gunderson LH (1994) Vegetation of the Everglades: Determinants of community composition. In: Davis SM, Ogden JC (eds) Everglades: The Ecosystem and its Restoration. St. Lucie Press, Delray Beach, Florida, pp 323-340

Hagerthey, S. E., B. J. Bellinger, K. Wheeler, M. Gantar, and E. Gaiser. In Press.Everglades Periphyton: A Biogeochemical Perspective. Reviews in Environmental Science and Technology.

Hasle, G., and G. Fryxell. 1970. Diatoms: cleaning and mounting for light and electron microscopy. Trans. Am. Microsc. Soc. 89: 470-474.

Hustedt, F. (1985). The pennate diatoms: a translation of Hustedt's "Die kieselalgen, 2. Teil.” Jensen, N. G. Koeltz scientific books

Ibarra C., Tavera, R. and Novelo, E. 2009. Diversity and structure of periphyton and metaphyton diatom communities in a tropical wetland in Mexico. Revista Mexicana de Biodiversidad 80: 763- 769.

Juggins. S. 2003. C2 User guide. Software for ecological and palaeoecological data analysis and visualisation. University of Newcastle, Newcastle upon Tyne, UK. 69pp.

Krammer, K. and Lange-Bertalot, H. 1997a. Bacillariophyceae1. Teil: Naviculaceae. In Ettl, H., J. Gerloff, H. Heynig, and D. Mollenhauer, (Eds.). Süsswasserflora von Mitteleuropa, Band 2/1. Gustav Fischer Verlag: Stuttgart, New York. 876 pp. 
Krammer, K. and H. Lange-Bertalot. 1997b. Bacillariophyceae 2. Teil: Bacillariaceae, Epithemiaceae, Surirellaceae. In Ettl, H., J. Gerloff, H. Heynig, and D. Mollenhauer, (Eds.). Süsswasserflora von Mitteleuropa, Band 2/2.Gustav Fischer Verlag. Stuttgart, Germany.

Krammer, K. and H. Lange-Bertalot. 1991a. Bacillariophyceae 3. Teil: Centrales, Fragilariaceae, Eunotiaceae. In Ettl, H., J. Gerloff, H. Heynig, and D. Mollenhauer, (Eds.). Süsswasserflora von Mitteleuropa, Band 2/3.Gustav Fischer Verlag. Stuttgart, Germany.

Krammer, K. and H. Lange-Bertalot. 1991b. Bacillariophyceae 4. Teil: Achnanthaceae. Kritische Ergänzungen zu Achnanthes s.l., Navicula s.str., Gomphonema. In Ettl, H., J. Gerloff, H. Heynig, and D. Mollenhauer, (Eds.). Süsswasserflora von Mitteleuropa Band 2/4.Gustav Fisher Verlag. Stuttgart, Germany.

Krammer, K. and H. Lange-Bertalot. 2004. Bacillariophyceae 4. Teil: Achnanthaceae. Kritische Ergänzungen zu Achnanthes s.l., Navicula s.str., Gomphonema, $2^{\text {nd }}$ Edition. In Ettl, H., J. Gerloff, H. Heynig, and D. Mollenhauer, (Eds.). Süsswasserflora von Mitteleuropa Band 2/4.Gustav Fisher Verlag. Stuttgart, Germany.

Krammer, K. 1997a. Die cymbelloiden Diatomeen - Eine Monographie der weltweit bekannten Taxa. Teil 1. Allgemeines und Encyonema Part. Bibliotheca Diatomologica $36: 382 \mathrm{pp}$.

Krammer, K. 1997b. Die cymbelloiden Diatomeen. Eine Monographie der weltweit bekannten Taxa. Teil 2. Encyonema part., Encyonopsis and Cymbellopsis. Bibliotheca Diatomologica, Vol: 37, 463 pp.

Krammer, K. 2000 - Diatoms of Europe: Diatoms of the European inland waters and comparable habitats. Vol. 1. The genus Pinnularia. A.R.G. Gantner Verlag K.G, Ruggell. $703 \mathrm{pp}$.

Kushlan, J. A. 1981. Sampling characteristics of enclosure fish traps. Transactions of the American Fisheries Society 110: 557-662. 
La Hée, J. M., Gaiser, E. E., Trexler, J. C. and Loftus, W. F. In preparation. Phosphorus and hydrology as drivers of periphyton biomass in the Everglades and three tropical karstic wetlands.

Lange-Bertalot, H. (1993) Bibliotheca Diatomologica Band 27. 85 New taxa and much more than 100 taxonomic clarifications supplementary to Suesswasserflora von Mitteleuropa, Volume 2/1-4, J. Cramer, Stuttgart. 454 pp.

Lange-Bertalot, H. \& Moser, G. (1994) - Brachysira Monographie der Gattungen. Bibliotheca Diatomologica 29. J. Cramer, Stuttgart. 212 pp.

Liston SE, Newman S, Trexler JC (2008) Macroinvertebrate community response to eutrophication in an oligotrophic wetland: An in situ mesocosm experiment. Wetlands 28:686-694

Massa AK, Haynes-Sutton A (1998) Environmental Policy Framework, Parish of St. Elizabeth, Jamaica. Technical Support Services Inc. Prepared for the Natural Resources Conservation Authority Protected Areas Management Branch and the United States Agency for International Development.

McCormick PV, O’Dell MB (1996) Quantifying periphyton responses to phosphorus in the Florida Everglades: a synoptic-experimental approach Journal of the North American Benthological Society 15:450-468

McCormick PV, Rawlik PS, Lurding K, Smith EP, Sklar FH (1996) Periphyton-water quality relationships along a nutrient gradient in the northern Everglades. Journal of the North American Benthological Society 15: 433-449

McCormick PV, Stevenson RJ (1998) Periphyton as a tool for ecological assessment and management in the Florida Everglades. Journal of Phycology 34:726-733

McCormick, P.V. and Scinto, L.J., 1999. Influence of phosphorus loading on wetlands periphyton assemblages: A case study from the Everglades. In: Reddy, K.R., Editor, 1999. Phosphorus Biogeochemistry in Subtropical Ecosystems, CRC Press, Boca Raton, FL, pp. 301-319. 
McCormick, P. V., M. B. O'Dell, R. B E. Shuford III, J. G. Backus, and W. C. Kennedy. 2001. Periphyton responses to experimental phosphorus enrichment in a subtropical wetland. Aquatic Botany 71:119-139.

McCune B, Grace JB (2002) Analysis of Ecological Communities, MJM Press, Gleneden Beach, Oregon, USA

Meerman JC (2006) Ecological Characterization of the New River Lagoon, Orange Walk District, Belize. Report prepared for the Freshwater Programme for Belize, Belize City

Metzeltin, D. and Lange-Bertalot, H. (1998) Tropical diatoms of South America I: About 700 predominantly rarely known or new taxa representative of the neotropical flora. In: Lange-Bertalot, H. (ed.), Iconographia Diatomologica. Annotated Diatom Micrographs. Vol. 5. Diversity-Taxonomy-Geobotany. Koeltz Scientific Books. Königstein, Germany, Vol: 5, $695 \mathrm{pp}$.

Metzeltin, D. and Lange-Bertalot, H. (2007) Tropical diatoms of South America II. Special remarks on biogeography disjunction In: H. Lange-Bertalot (ed.), Iconographia Diatomologica. Annotated Diatom Micrographs. Vol. 18. Diversity-TaxonomyBiogeography. A.R.G. Gantner Verlag K.G., Vol: 18, 1-877

Metzeltin, D., Lange-Bertalot, H. and García-Rodríguez, F. 2005. Diatoms of Uruguay. Compared with other taxa from South America and elsewhere. In: H. Lange-Bertalot (ed.), Iconographia Diatomologica. Annotated Diatom Micrographs. Vol. 15. TaxonomyBiogeography-Diversity. A.R.G. Gantner Verlag K.G. 15:736 pp.

Munyon, J.W., J.S. Schedlbauer, S.F. Oberbauer, E.E. Gaiser, and G. Starr. In preparation. Contrasting ecosystem productivity between a long- and short-hydroperiod marsh in the Florida Everglades.

Noe GB, Childers DL (2007) Phosphorus budgets in Everglades wetland ecosystems: the effects of hydrology and nutrient enrichment. Wetlands Ecology Management 15:189205

Neto, R., R.N. Mead, W.J. Louda, R. Jaffe. 2006. Organic biogeochemistry of detrital flocculent material (floc) in a subtropical, coastal wetland. Biogeochemistry , 77: 283304. 
Noe, G. B., Childers, D. L. and Jones, R. D. 2001. Phosphorus biogeochemistry and the impact of phosphorus enrichment: Why is the Everglades so unique? Ecosystems 4: 603624.

Novelo E, Tavera R, Ibarra C (2007) Bacillariophyceae from Karstic Wetlands in Mexico. Bibliotheca Diatomologica 54:1-136

Novelo E, Tavera R (2003) The role of periphyton in the regulation and supply of nutrients in a wetland at El Edén, Quintana Roo. In: Gómez-Pompa A, Allen MF, Fedick SL, Jiménez-Osornio JJ (eds.) The Lowland Maya Area. Three Millennia and the Human-Wildland Interface. Food Products Press, NY, pp 217-239

Pan, Y., Stevenson, R.J., Vaithiyanathan, P., Slate, J., Richardson, C.J., 2000. Changes in algal assemblages along observed and experimental phosphorus gradients in a subtropical wetland, USA. Freshwater Biol. 44, 339-353.

Podzorski A.C. 1985. An Illustrated and Annotated Check-List of Diatoms from the Black River Waterways, St. Elizabeth, Jamaica. Bibliotheca Diatomologica. 7:1-177

Rejmánková E and Komárková J (2000) Function of cyanobacterial mats in phosphoruslimited tropical wetlands. Hydrobiologia 431:135-153

Rejmánková, E. and J. Komárková. 2005. Response of cyanobacterial mats to nutrient and salinity changes. Aquatic Botany 83:87-107.

Rejmánková E, Pope KO, Post R, Maltby E (1996) Herbaceous wetlands of the Yucatan peninsula: communities at extreme ends of environmental gradients. Internationale Revue der Gesamten Hydrobiologie 81:223-252

Scinto, L.J. and K.R. Reddy. 2003. Biotic and abiotic uptake of phosphorus by periphyton in a subtropical freshwater wetland. Aquatic Botany 77: 203-222.Siegel and German, 1982

Siver, P. A., Hamilton, P. B., Stachura-Suchoples, K., Kociolek, J. P. 2005. Diatoms of North America: The freshwater flora of Cape Cod, Massachusetts, U.S.A. Iconographia Diatomologica. Volume 14. A.R.G. Gantner Verlag K.G., 
Slate, J.E., and R.J. Stevenson. 2000. Recent and abrupt environmental change in the Florida Everglades indicated from siliceous microfossils. Wetlands 20:346-356.

Slate, J. E. and R. J. Stevenson. 2007. The diatom flora of phosphorus-enriched and unenriched sites in an Everglades marsh. Diatom Research 22: 355-386.

Solórzano JH, Sharp L (1980) Determination of total dissolved phosphorous and particulate phosphorous in natural waters, Limnology and Oceanography 25:754-758

Stal LJ (2000) Cyanobacterial mats and stromatolites. In: Whitton BA, Potts M (eds) The Ecology of Cyanobacteria: Their Diversity in Time and Space. Kluwer Academic Publishers, Dordrecht, The Netherlands, pp 61-120

Swift DR, Nicholas RB (1987) Periphyton and water quality relationships in the Everglades Water Conservation Areas, 1978-1982. Technical Publication 872, South Florida Water Management District, West Palm Beach, Florida

Tanaka, 2007. Taxonomic studies of the genera Cyclotella (Kützing) Brébisson, Discostella Houk et Klee and Puncticulata Hakansson in the family Stephanodiscaceae Glezer et Makarova (Bacillariophyta) in Japan. Bibliotheca Diatomologica. 53:1-204

Thomas S, Gaiser EE, Gantar M, Scinto L, Jones RD (2006) Quantifying the response of calcareous periphyton crusts to rehydration: a microcosm study (Florida Everglades). Aquatic Botany 84:317-323

Tobias, F. A. C. and Gaiser, E. E. 2006. Taxonomy and distribution of taxa in the genus Gomphonema from the Florida Everglades, U.S.A. Diatom Research 21: 379-405.

Van Meter-Kasanof N (1973) Ecology of the microalgae of the Florida Everglades. Part I. Environment and some aspects of freshwater periphyton, 1959 to 1963 . Nova Hedwigia 24:619-664

Wachnicka, A. H. and Gasier, E. E. 2007. Morphological characterization of Amphora and Seminavis (Bacillariophyceae) from South Florida, U.S.A. Diatom Research 22: 387455. 
Weidie AE (1985) Geology of the Yucatan platform. In: Ward WC, Weidie AE, Back W (eds) Geology and hydrology of the Yucatan and Quaternary geology of northeastern Yucatan peninsula New Orleans Geological Society, pp 1-19

Williams AJ, Trexler JC (2006) A preliminary analysis of the correlation of food-web characteristics with hydrology and nutrient gradients in the southern Everglades. Hydrobiologia 569:493-504

Witkowski, A., Lange-Bertalot, H. and Metzeltin, D. (2000) Diatom Flora of Marine Coasts I. In: Lange-Bertalot, H. (ed.), Iconographia Diatomologica. Annotated Diatom Micrographs. Vol. 7. Diversity-Taxonomy-Identification. Koeltz Scientific Books, Königstein, Germany, 7:925 pp., 219 pls 
Table 3-1. Location of Caribbean sampling sites, presented as latitudinal and longitudinal bounding GPS coordinates of sampling sites within each location.

\begin{tabular}{lccc}
\hline & $\begin{array}{c}\text { Sian Ka'an National Park, } \\
\text { Quintana Roo, Mexico }\end{array}$ & $\begin{array}{c}\text { New River Lagoon, Indian } \\
\text { Church, Belize }\end{array}$ & $\begin{array}{c}\text { Slipe River, Black River Morass, } \\
\text { St. Elizabeth, Jamaica }\end{array}$ \\
\hline EAST & $087^{\circ} 30.585$ & $88^{\circ} 37.958^{\prime}$ & $78^{\circ} 46.972$ \\
WEST & $087^{\circ} 57.579$ & $88^{\circ} 39.212^{\prime}$ & $77^{\circ} 48.874$ \\
NORTH & $19^{\circ} 52.342$ & $17^{\circ} 47.111^{\prime}$ & $18^{\circ} 03.182$ \\
SOUTH & $18^{\circ} 47.223$ & $17^{\circ} 37.166$ & $18^{\circ} 01.524$ \\
\hline
\end{tabular}

Table 3-2. Number of sites sampled (N), water characteristics and periphyton attributes for each location during wet and dry periods. Average values are given along with standard deviation values in brackets. Missing data are indicated with a dash (-).

\begin{tabular}{|c|c|c|c|c|c|c|c|c|c|c|c|c|}
\hline SITE & $\mathrm{N}$ & $\mathrm{pH}$ & $\begin{array}{l}\text { Conductivity } \\
\qquad\left(\mu \mathrm{S} \mathrm{cm}^{-1}\right)\end{array}$ & $\begin{array}{l}\text { Water } \\
\text { depth } \\
(\mathrm{cm})\end{array}$ & $\begin{array}{c}\text { Total } \\
\text { Biovolume } \\
\left(\mathrm{ml} \mathrm{m}^{-2}\right)\end{array}$ & $\begin{array}{l}\text { Biovolume } \\
\left(\mathrm{ml} \mathrm{m}^{-2}\right)\end{array}$ & $\begin{array}{c}\mathrm{TP} \\
(\mu \mathrm{g} \mathrm{P} \\
\mathrm{g}^{-1} \\
\mathrm{DM})\end{array}$ & $\begin{array}{c}\text { Dry } \\
\text { Mass } \\
\left(\mathrm{g} \mathrm{m}^{-2}\right)\end{array}$ & $\begin{array}{c}\text { Organic } \\
\text { content } \\
(\%)\end{array}$ & $\begin{array}{l}\text { Ash } \\
\text { Free } \\
\text { Dry } \\
\text { Mass } \\
\left(\mathrm{g} \mathrm{m}^{-}\right. \\
\left.{ }^{2}\right)\end{array}$ & $\begin{array}{l}\text { Chlorophyll } \\
\quad\left(\mu \mathrm{g} \mathrm{m}^{-2}\right)\end{array}$ & $\begin{array}{l}\text { Chlorophyll } \\
\text { concentration } \\
\left(\mu \mathrm{g} \mathrm{g}^{-1} \mathrm{DM}\right)\end{array}$ \\
\hline $\begin{array}{l}\text { Belize } \\
\text { Wet }\end{array}$ & 12 & $\begin{array}{c}7.3 \\
(0.5)\end{array}$ & $\begin{array}{c}441.8 \\
(208.6)\end{array}$ & $\begin{array}{l}73.2 \\
(8.5)\end{array}$ & $\begin{array}{c}876.0 \\
(1474.8)\end{array}$ & $\begin{array}{c}857.1 \\
(1486.4)\end{array}$ & $\begin{array}{c}239.7 \\
(106.7)\end{array}$ & $\begin{array}{c}77.1 \\
(133.4)\end{array}$ & $\begin{array}{c}67.8 \\
(19.1)\end{array}$ & $\begin{array}{c}30.1 \\
(48.2)\end{array}$ & $\begin{array}{c}140.2 \\
(132.7)\end{array}$ & $\begin{array}{c}48.3 \\
(52.5)\end{array}$ \\
\hline $\begin{array}{l}\text { Belize } \\
\text { Dry }\end{array}$ & 9 & $\begin{array}{c}8.3 \\
(0.2)\end{array}$ & $\begin{array}{c}690.3 \\
(104.0)\end{array}$ & $\begin{array}{c}31.6 \\
(11.8)\end{array}$ & $\begin{array}{c}101.6 \\
(264.6)\end{array}$ & $\begin{array}{c}101.6 \\
(264.6)\end{array}$ & $\begin{array}{c}543.1 \\
(187.9)\end{array}$ & $\begin{array}{c}3.2 \\
(6.7)\end{array}$ & $\begin{array}{c}37.4 \\
(17.9)\end{array}$ & $\begin{array}{c}1.5 \\
(3.0)\end{array}$ & $\begin{array}{c}1288.5 \\
(2602.0)\end{array}$ & $\begin{array}{c}260.6 \\
(175.0)\end{array}$ \\
\hline $\begin{array}{l}\text { Jamaica } \\
\text { Wet }\end{array}$ & 5 & $\begin{array}{c}7.9 \\
(0.2)\end{array}$ & $\begin{array}{l}522.6 \\
(62.4)\end{array}$ & $\begin{array}{c}9.6 \\
(3.6)\end{array}$ & - & - & $\begin{array}{c}405.2 \\
(158.3)\end{array}$ & - & - & - & - & - \\
\hline $\begin{array}{l}\text { Jamaica } \\
\text { Dry }\end{array}$ & 5 & $\begin{array}{c}8.4 \\
(0.5)\end{array}$ & $\begin{array}{c}447.6 \\
(137.3)\end{array}$ & $\begin{array}{c}11.6 \\
(12.7)\end{array}$ & $\begin{array}{c}2251.3 \\
(1712.6)\end{array}$ & $\begin{array}{c}2251.3 \\
(1712.6)\end{array}$ & $\begin{array}{l}200.3 \\
(16.5)\end{array}$ & $\begin{array}{c}156.0 \\
(104.8)\end{array}$ & $\begin{array}{l}28.7 \\
(7.2)\end{array}$ & $\begin{array}{c}39.4 \\
(25.5)\end{array}$ & $\begin{array}{c}29693.0 \\
(19940.6)\end{array}$ & $\begin{array}{l}222.5 \\
(83.1)\end{array}$ \\
\hline $\begin{array}{l}\text { Mexico } \\
\text { Wet }\end{array}$ & 6 & - & $\begin{array}{l}1259.0 \\
(952.5)\end{array}$ & $\begin{array}{c}37.9 \\
(10.3)\end{array}$ & $\begin{array}{c}7460.7 \\
(3043.8)\end{array}$ & $\begin{array}{c}6772.6 \\
(2957.6)\end{array}$ & $\begin{array}{l}212.5 \\
(93.7)\end{array}$ & $\begin{array}{c}365.0 \\
(195.5)\end{array}$ & $\begin{array}{l}37.9 \\
(7.4)\end{array}$ & $\begin{array}{l}121.4 \\
(49.5)\end{array}$ & $\begin{array}{c}37195.4 \\
(12261.7)\end{array}$ & $\begin{array}{l}129.7 \\
(51.5)\end{array}$ \\
\hline $\begin{array}{l}\text { Mexico } \\
\text { Dry }\end{array}$ & 4 & $\begin{array}{c}9.2 \\
(0.4)\end{array}$ & $\begin{array}{c}15047.7 \\
(16670.5)\end{array}$ & $\begin{array}{c}30.3 \\
(23.4)\end{array}$ & $\begin{array}{c}4564.3 \\
(2568.5)\end{array}$ & $\begin{array}{l}4144.6 \\
(2720)\end{array}$ & $\begin{array}{c}193.7 \\
(210.9)\end{array}$ & $\begin{array}{c}317.4 \\
(233.9)\end{array}$ & $\begin{array}{c}42.5 \\
(15.5)\end{array}$ & $\begin{array}{l}109.4 \\
(76.5)\end{array}$ & $\begin{array}{c}133456.4 \\
(153012.9)\end{array}$ & $\begin{array}{c}465.3 \\
(257.1)\end{array}$ \\
\hline
\end{tabular}


Table 3-3. List of non-rare species showing the number of locations $(\mathrm{N})$ at which each species was found, along with an indicator of average percentage abundance at each location: Belize (B), Mexico (M) and Jamaica (J). Rare ( $<1 \%)$ : *; Uncommon $(1$ to $<5 \%)$ : **; Common $(5$ to $<20 \%)$ : ***; Abundant $(>20 \%)$ : ****. Species absence from a location is indicated with a dash $(-)$.

\begin{tabular}{|l|c|c|c|c|}
\hline & $\mathrm{N}$ & & $\begin{array}{c}\text { Avg. } \\
\text { Per. } \\
\text { Abun. }\end{array}$ & \\
\hline & & $\mathrm{B}$ & $\mathrm{M}$ & $\mathrm{J}$ \\
\hline Achnanthidium neomicrocephalum H. Lange-Bertalot \& F. Staab & 3 & $* * * *$ & $*$ & $* *$ \\
\hline Brachysira neoexilis Lange-Bertalot & 3 & $* * * *$ & $* * *$ & $* * *$ \\
\hline Brachysira procera Lange-Bertalot \& Moser & 3 & $* * * *$ & $* * *$ & $* * *$ \\
\hline Caponea caribbea Podzorski & 3 & $*$ & $*$ & $*$ \\
\hline Cyclotella meneghiniana Kützing & 3 & $*$ & $* *$ & $*$ \\
\hline Diploneis oblongella (Naegeli ex Kuetzing) Ross & 3 & $*$ & $*$ & $* *$ \\
\hline Diploneis parma Cleve & 3 & $*$ & $*$ & $* *$ \\
\hline Encyonema evergladianum Krammer & 3 & $* * *$ & $* * * *$ & $* * * *$ \\
\hline Encyonema sp.2 & 3 & $* *$ & $* * *$ & $* *$ \\
\hline Encyonema sp.3 & 3 & $*$ & $*$ & $*$ \\
\hline Encyonopsis microcephala (Grunow) Krammer & 3 & $*$ & $* *$ & $* * *$ \\
\hline Encyonopsis subminuta Krammer et Reichardt & 3 & $*$ & $* *$ & $* *$ \\
\hline Eunotia flexuosa (Brébisson) Kützing & 3 & $*$ & $*$ & $*$ \\
\hline Fragilaria (?) sp.1 cf. famelica (Kützing) Lange-Bertalot & 3 & $* *$ & $* *$ & $* *$ \\
\hline Fragilaria synegrotesca Lange-Bertalot & 3 & $* * *$ & $* * *$ & $* * *$ \\
\hline Fragilaria ulna var. ulna (Nitzsch) Lange-Bertalot & 3 & $* *$ & $*$ & $*$ \\
\hline Gomphonema intricatum var. vibrio (Ehrenberg) Cleve & 3 & $* *$ & $*$ & $*$ \\
\hline
\end{tabular}


Table 3-3. C'ntd.

\begin{tabular}{|l|c|c|c|c|}
\hline & $\mathrm{N}$ & & $\begin{array}{c}\text { Avg. } \\
\text { Per. } \\
\text { Abun. }\end{array}$ & \\
\hline Gomphonema cf. vibriodes Reichardt \& Lange-Bertalot & 3 & $* *$ & $* *$ & $*$ \\
\hline Mastogloia cf. smithii Thwaites ex. W. Smith & 3 & $* * *$ & $* * * *$ & $* * *$ \\
\hline Mastogloia smithii var. lacustris Grunow & 3 & $* *$ & $* *$ & $*$ \\
\hline Navicula cf. radiosa Kützing & 3 & $* *$ & $* *$ & $* *$ \\
\hline Navicula cryptotenella Lange-Bertalot & 3 & $* *$ & $* *$ & $* *$ \\
\hline Navicula subtilissima Cleve & 3 & $* *$ & $*$ & $* *$ \\
\hline Nitzschia lacunarum Hustedt & 3 & $*$ & $*$ & $*$ \\
\hline Nitzschia palaea (Kutzing) Smith & 3 & $* *$ & $* * *$ & $* * *$ \\
\hline Nitzschia semirobusta Lange-Bertalot & 3 & $* *$ & $* * *$ & $* * *$ \\
\hline Nitzschia serpentiraphe Lange-Bertalot & 3 & $* *$ & $* *$ & $* *$ \\
\hline Sellaphora laevissima (Kützing) Krammer & 3 & $*$ & $*$ & $*$ \\
\hline Anomoneis sphaerophora (Ehrenberg) Pfitzer & 2 & $*$ & $*$ & - \\
\hline Encyonema silesiacum (Bleisch) Mann & 2 & $*$ & $*$ & - \\
\hline Eunotia camelus Ehrenberg & 2 & $* * *$ & $*$ & - \\
\hline Eunotia cf. karenae Metzeltin \& Lange-Bertalot & 2 & $* *$ & $*$ & - \\
\hline Navicella pusilla (Grunow) Krammer & 2 & $*$ & $* * *$ & - \\
\hline Nitzschia denticula Grunow & 2 & $* * *$ & $* * *$ & - \\
\hline Nitzschia microcephala Grunow & 2 & $*$ & $* *$ & - \\
\hline Pinnularia sp.1 & 2 & $*$ & $*$ & - \\
\hline
\end{tabular}


Table 3-3. C'ntd.

\begin{tabular}{|l|c|c|c|c|}
\hline & $\mathrm{N}$ & & $\begin{array}{c}\text { Avg. } \\
\text { Per. } \\
\text { Abun. }\end{array}$ & \\
\hline Plagiotropis sp.1 & 2 & $* *$ & $*$ & - \\
\hline Amphora sulcata (Brébisson) Cleve & 2 & - & $* *$ & $* *$ \\
\hline Gomphonema affine Kützing & 2 & - & $*$ & $*$ \\
\hline Mastogloia braunii Grunow & 2 & - & $* *$ & $*$ \\
\hline Nitzschia linearis var. subtilis (Grunow) Hustedt & 2 & - & $* * *$ & $* *$ \\
\hline Rhopalodia gibba (Ehrenberg) Muller & 2 & - & $*$ & $* *$ \\
\hline Achnanthidium exiguum (Grunow) Czarnecki & 2 & $* *$ & - & $*$ \\
\hline Achnanthidium sp.1 & 2 & $* *$ & - & $*$ \\
\hline Amphora copulata (Kützing) Schoeman \& Archibald & 2 & $*$ & - & $*$ \\
\hline Caloneis sp.1 & 2 & $*$ & - & $*$ \\
\hline Cocconeis placentula Ehrenberg & 2 & $*$ & - & $*$ \\
\hline Eunotia cf. yberai Frenguelli & 2 & $*$ & - & $*$ \\
\hline Fragilaria capucina var. vaucheriae (Kützing) Lange-Bertalot & 2 & $*$ & - & $*$ \\
\hline Gomphonema gracile Ehrenberg & 2 & $*$ & - & $*$ \\
\hline Mastogloia elliptica (Agardh) Cleve & 2 & $* *$ & - & $* *$ \\
\hline Navicula stroemii Hustedt & 2 & $*$ & - & $*$ \\
\hline Neidium ampliatum (Ehrenberg) Krammer & 2 & $*$ & - & $*$ \\
\hline Nitzschia nana Grunow & 2 & $*$ & - & $*$ \\
\hline Pinnularia microstauron (Ehrenberg) Cleve & 2 & $*$ & - & $*$ \\
\hline
\end{tabular}


Table 3-3. C'ntd.

\begin{tabular}{|l|c|c|c|c|}
\hline & $\mathrm{N}$ & & $\begin{array}{c}\text { Avg. } \\
\text { Per. } \\
\text { Abun. }\end{array}$ & $*$ \\
\hline Sellaphora pupula (Kützing) Mereschkowsky & 2 & $*$ & - & $*$ \\
\hline Staurosira construens Ehrenberg & 2 & $* *$ & - & $*$ \\
\hline Staurosirella pinnata var. pinnata (Ehrenberg) Williams \& Round & 2 & $* *$ & - & $*$ \\
\hline Synedra acus var. angustissima (Grunow) Van Heurck & 2 & $*$ & - & $*$ \\
\hline Aulacoseira ambigua (Grunow) Simonsen & 1 & $* *$ & - & - \\
\hline Aulacoseira granulata (Ehrenberg) Simonsen & 1 & $* *$ & - & - \\
\hline Brachysira brebissonii Ross & 1 & $* * * *$ & - & - \\
\hline Brachysira pumila Metzeltin \& Lange-Bertalot & 1 & $* * *$ & - & - \\
\hline Craticula cuspidata (Kützing) Mann & 1 & $*$ & - & - \\
\hline Craticula sp.1 & 1 & $*$ & - & - \\
\hline Cymbella aspera (Ehrenberg) Cleve & 1 & $*$ & - & - \\
\hline Diploneis sp.5 & 1 & $*$ & - & - \\
\hline Diploneis sp.6 & 1 & $*$ & - & - \\
\hline Epithemia sp.1 & 1 & $*$ & - & - \\
\hline Eunotia botuliformis Wild, Norpel \& Lange-Bertalot & 1 & $*$ & - & - \\
\hline Eunotia cf. monodon Ehrenberg & 1 & $* *$ & - & - \\
\hline Eunotia implicata Nörpel, Lange-Bertalot \& Alles & 1 & $*$ & - & - \\
\hline
\end{tabular}


Table 3-3. C'ntd.

\begin{tabular}{|l|c|c|c|c|}
\hline & $\mathrm{N}$ & & $\begin{array}{c}\text { Avg. } \\
\text { Abr. } \\
\text { Abun. }\end{array}$ & \\
\hline Eunotia naegelii Migula & 1 & $*$ & - & - \\
\hline Eunotia rabenhorstiana var. elongata (Patrick) Metzeltin \& Lange-Bertalot & 1 & $*$ & - & - \\
\hline Eunotia sp.1 & 1 & $*$ & - & - \\
\hline Eunotia sp.2 & 1 & $*$ & - & - \\
\hline Eunotia sp.3 & 1 & $*$ & - & - \\
\hline Fallacia pygmaea (Kützing) Stickle \& Mann & 1 & $* *$ & - & - \\
\hline Frustulia rhomboides var. crassinervia (Brebisson ex. W. Smith) Ross & 1 & $*$ & - & - \\
\hline Gomphonema parvulum (Kützing) Grunow & 1 & $*$ & - & - \\
\hline Hantzschia cf. elongata (Hantzsch) Grunow & 1 & $*$ & - & - \\
\hline Hantzschia spectabilis (Ehrenberg) Hustedt & 1 & $*$ & - & - \\
\hline Mastogloia elliptica var. dansei (Thwaites) Cleve & 1 & $*$ & - & - \\
\hline Navicula brasiliana (Cleve) Cleve & 1 & $*$ & - & - \\
\hline Navicula constans Hustedt & 1 & $*$ & - & - \\
\hline Nitzschia amphibia (Grunow) Lange-Bertalot & 1 & $* * *$ & - & - \\
\hline Nitzschia scalaris (Ehrenberg) Smith & 1 & $*$ & - & - \\
\hline Nitzschia thermalis var. minor Hilse & 1 & $*$ & - & - \\
\hline
\end{tabular}


Table 3-3. C'ntd.

\begin{tabular}{|l|c|c|c|c|}
\hline & $\mathrm{N}$ & & $\begin{array}{c}\text { Avg. } \\
\text { Per. } \\
\text { Abun. }\end{array}$ & \\
\hline Pinnularia acrosphaeria (Brébisson) W. Smith & 1 & $*$ & - & - \\
\hline Pinnularia cf. neomajor var. inflata Krammer & 1 & $*$ & - & - \\
\hline Pinnularia sp.2 & 1 & $*$ & - & - \\
\hline Pinnularia sp.4 & 1 & $*$ & - & - \\
\hline Pinnularia sp.5 & 1 & $*$ & - & - \\
\hline Pinnularia sp.7 & 1 & $*$ & - & - \\
\hline Pinnularia stoermeri Metzeltin \& Lange-Bertalot & 1 & $*$ & - & - \\
\hline Pinnularia tropica Hustedt & 1 & $*$ & - & - \\
\hline Stauroneis cf. smithii var. incisa Pantocsek & 1 & $*$ & - & - \\
\hline Stauroneis pachycephala Cleve & 1 & $*$ & - & - \\
\hline Stauroneis phoenicentron (Nitzsch) Ehrenberg & 1 & $*$ & - & - \\
\hline Stenopterobia curvula (Smith) Krammer & 1 & $*$ & - & - \\
\hline Surrirella elegans f. elongata Skvortzow & 1 & $*$ & - & - \\
\hline Unknown sp.1 & 1 & $*$ & - & - \\
\hline Unknown sp.2 & 1 & $*$ & - & - \\
\hline
\end{tabular}


Table 3-3. C'ntd.

\begin{tabular}{|l|c|c|c|c|}
\hline & $\mathrm{N}$ & & $\begin{array}{c}\text { Avg. } \\
\text { Per. } \\
\text { Abun. }\end{array}$ & \\
\hline Amphora cymbifera var. heritierarum Wachnicka \& Gaiser & 1 & - & $*$ & - \\
\hline Amphora sp.2 & 1 & - & $*$ & - \\
\hline Amphora sp.3 & 1 & - & $*$ & - \\
\hline Amphora corpulenta var. capitata Tempere et Peragallo & 1 & - & $*$ & - \\
\hline Amphora pseudoproteus Wachnicka \& Gaiser & 1 & - & $*$ & - \\
\hline Brachysira estonarium Witkowski, Lange-Bertalot \& Metzeltin & 1 & - & $*$ & - \\
\hline Brachysira cf. hofmanniae Lange-Bertalot & 1 & - & $* *$ & - \\
\hline Cyclotella litoralis Lange \& Syvertsen & 1 & - & $*$ & - \\
\hline Cyclotella cf. atomus var. gracilis Genkil \& Kiss & 1 & - & $*$ & - \\
\hline Cyclotella sp.1 & 1 & - & $*$ & - \\
\hline Diploneis cf. elliptica var. tropica Frenguelli & 1 & - & $*$ & - \\
\hline Hantzschia cf. vivacior Lange-Bertalot & 1 & - & $*$ & - \\
\hline Mastogloia lanceolata Thwaites ex. Smith & 1 & - & $* * *$ & - \\
\hline Navicula palestinae Gerloff, Natour \& Rivera & 1 & - & $* *$ & - \\
\hline Navicula pseudocrassirostris Hustedt & 1 & - & $* *$ & - \\
\hline Nitzschia acicularis & 1 & - & $* *$ & - \\
\hline Nitzschia sp.1 & 1 & - & $* *$ & - \\
\hline Nitzschia sp.2 & 1 & - & $* *$ & - \\
\hline Parlibellus sp.1 & 1 & - & $* *$ & - \\
\hline
\end{tabular}


Table 3-3. C'ntd.

\begin{tabular}{|l|c|c|c|c|}
\hline Pinnularia divergens Smith & 1 & - & $*$ & - \\
\hline Pleurosigma sp.1 & 1 & - & $*$ & - \\
\hline Proschkinia sp.1 & 1 & - & $* *$ & - \\
\hline Seminavis eulensteinii (Grunow) Danielidis, Ford \& Kennett & 1 & - & $*$ & - \\
\hline Achnanthidium inflatum (Kützing) Hutton & 1 & - & - & $*$ \\
\hline Actinocyclus normanii (Gregory ex Greville) Hustedt & 1 & - & - & $*$ \\
\hline Caloneis sp.2 & 1 & - & - & $*$ \\
\hline Caloneis sp.3 & 1 & - & - & $*$ \\
\hline Diploneis elliptica & 1 & - & - & $*$ \\
\hline Diploneis cf. finnica & 1 & - & - & $*$ \\
\hline Diploneis sp.2 & 1 & - & - & $*$ \\
\hline Encyonema jemtlandicum var. venezolanum Krammer & 1 & - & - & $* *$ \\
\hline Encyonema sp.1 & 1 & - & - & $*$ \\
\hline Encyonema vulgare var. vulgare Krammer & 1 & - & - & $* *$ \\
\hline Fragilaria cf. ulna (Nitzsch) Lange-Bertalot & 1 & - & - & $*$ \\
\hline Nitzschia obtusa var. kurzii Rabenhorst ex Cleve \& Moller & 1 & - & - & $*$ \\
\hline Tabularia tabulata (Agardh) Snoeijs & 1 & - & - & $*$ \\
\hline Pinnularia pisciculus var. angusta Metzeltin \& Krammer & 1 & - & - & $*$ \\
\hline Planothidium frequentisimum & 1 & - & - & $*$ \\
\hline Sellaphora rioplatensis Metzeltin, Lange-Bertalot \& Garcia-Rodriguez & 1 & - & - & $*$ \\
\hline Sellaphora sp.1 & 1 & - & - & $*$ \\
\hline
\end{tabular}


Table 3-4. Average per-site species richness (S) and diversity $(\mathrm{H})$ for all locations. Standard deviations are indicated in parentheses.

\begin{tabular}{lcccc}
\hline \multicolumn{1}{c}{ Site } & No. of samples & $\begin{array}{c}\text { Total no. of } \\
\text { species }\end{array}$ & S & H \\
\hline BELIZE & 21 & 113 & $18.48(6.51)$ & $1.67(0.49)$ \\
MEXICO & 10 & 84 & $18.70(4.45)$ & $2.00(0.33)$ \\
JAMAICA & 10 & 87 & $21.90(4.41)$ & $2.01(0.22)$
\end{tabular}




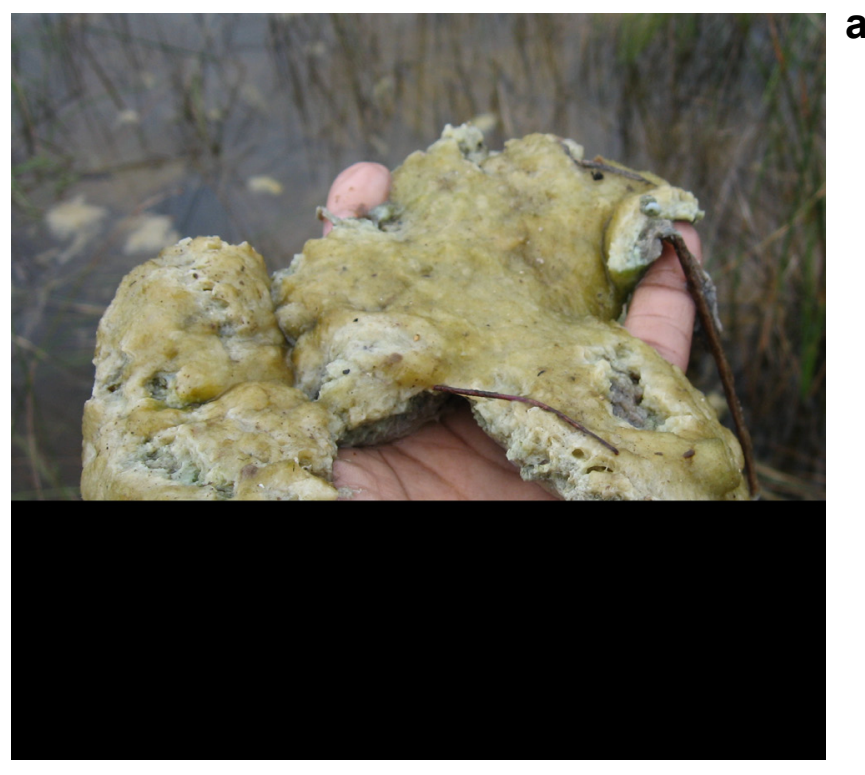

a

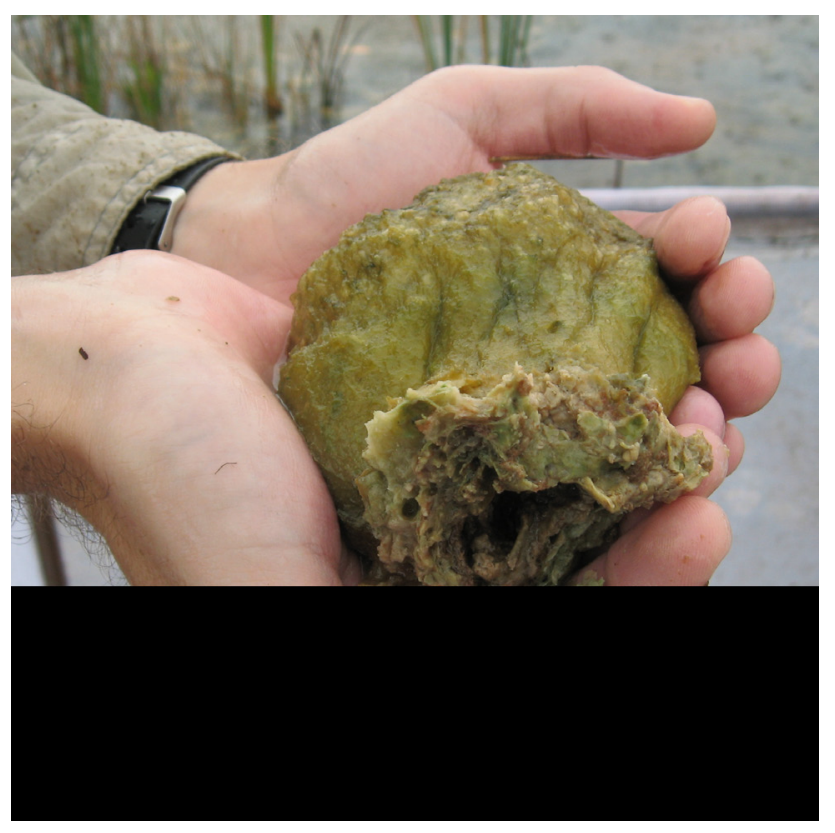

b

Figure 3-1. Benthic (a) and epiphytic (b) periphyton mat specimens collected from karstic marsh habitats. 


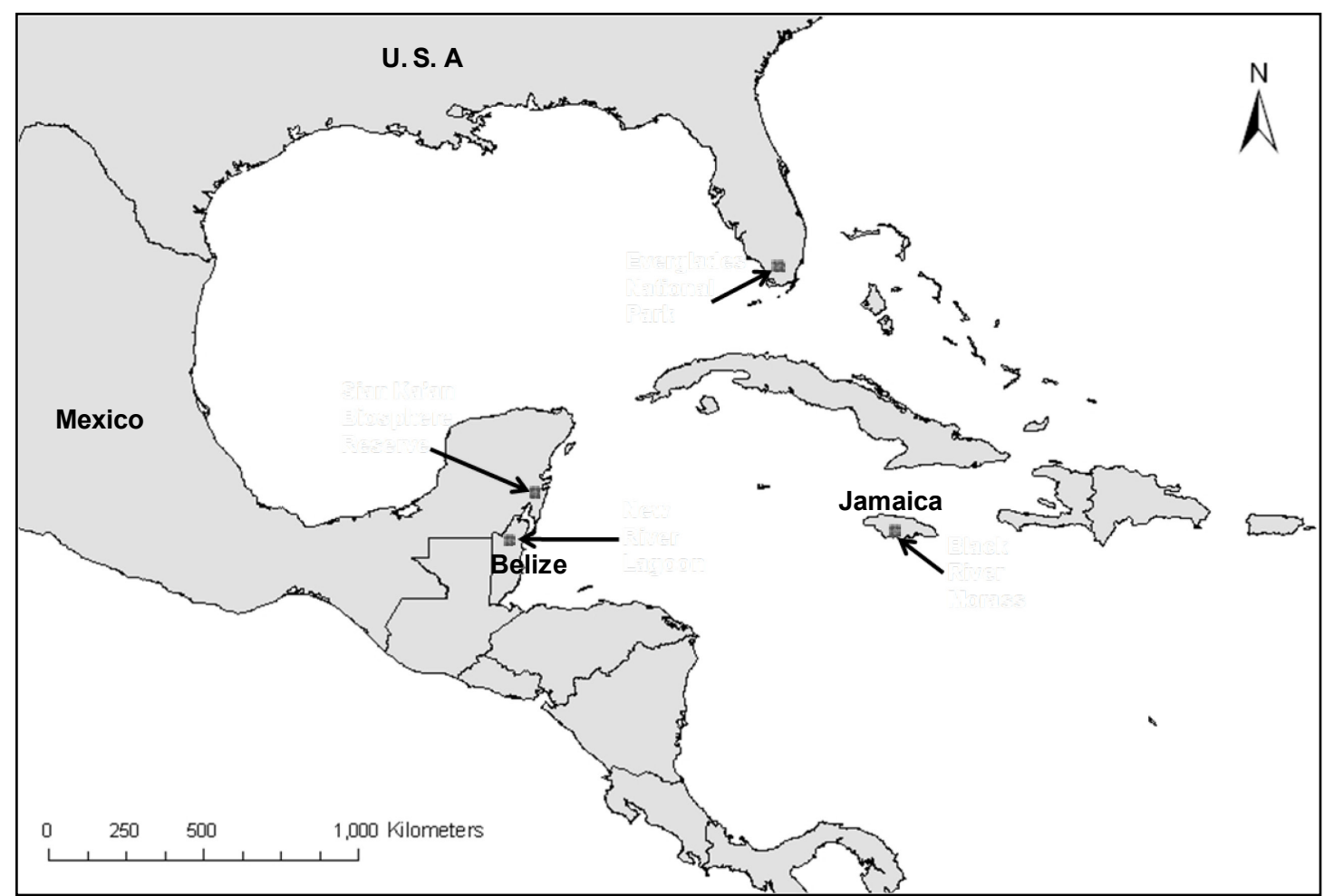

Figure 3-2. Map of northern Caribbean region showing the three sampling locations for this study. The Everglades location is included for comparison. 
Plate 1. Figures 1-1 through 1-18

Figure 1-1. Achnanthidium inflatum

Figure 1-2. Achnanthidium neomicrocephalum

Figure 1-3. Achnanthidium sp.1

Figure 1-4. Unknown species 1

Figure 1-5. Achnanthidium exiguum

Figure 1-6. Unknown species 2

Figure 1-7. Planothidium frequentisimum

Figure 1-8. Brachysira neoexilis

Figure 1-9. Brachysira brebissonii

Figure 1-10. Brachysira estonarium

Figure 1-11. Brachysira pumila

Figure 1-12. Stauroneis cf. smithii var. incisa

Figure 1-13. Sellaphora laevissima

Figure 1-14. Navicula stroemii

Figure 1-15. Sellaphora sp.1

Figure 1-16. Sellaphora rioplatensis

Figure 1-17. Aulacoseira ambigua

Figure 1-18. Aulacoseira granulata 

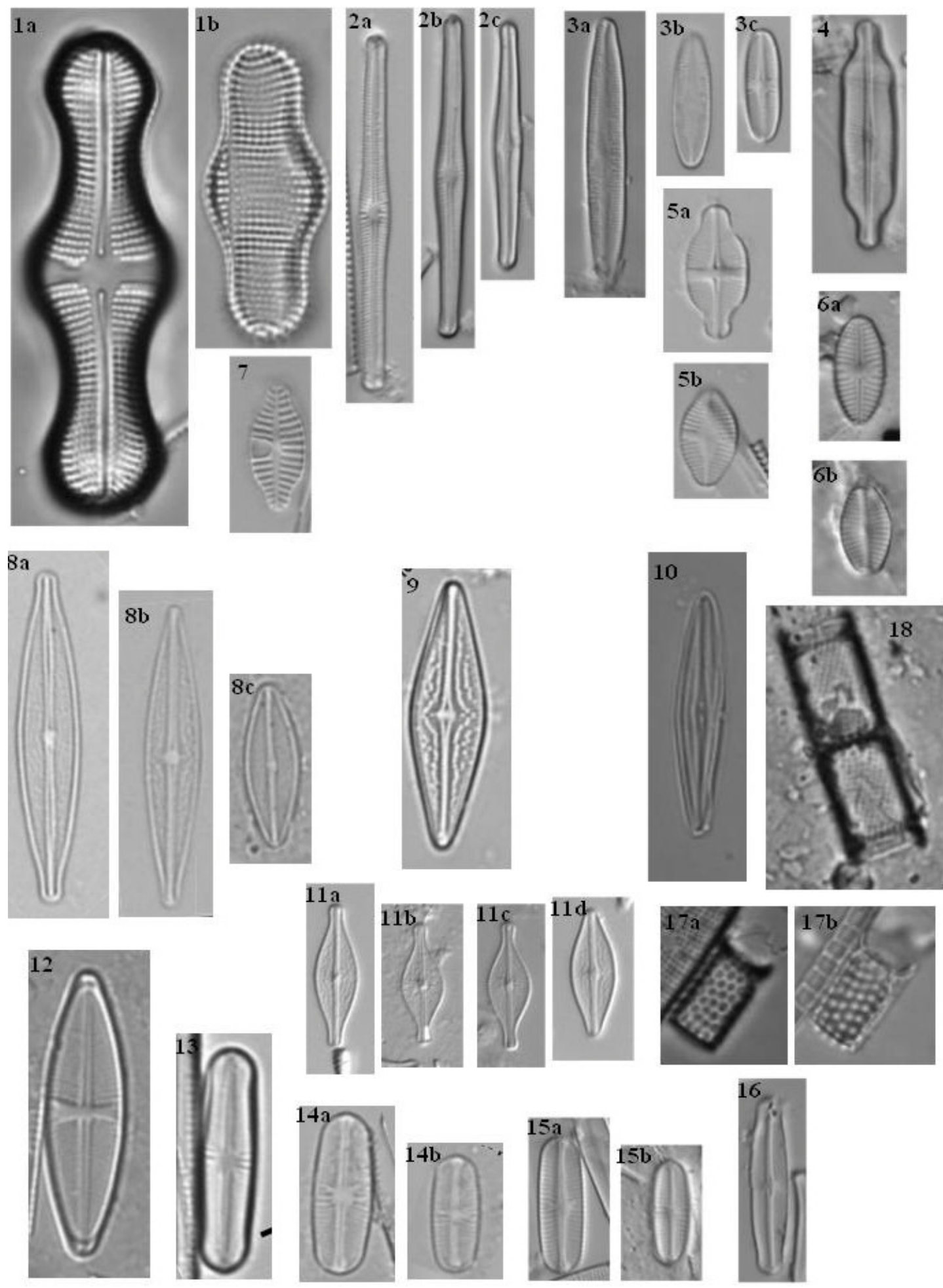
Plate 2. Figures 2-1 through 2-7

Figure 2-1. Brachysira cf. hofmanniae

Figure 2-2. Brachysira procera

Figure 2-3. Cyclotella litoralis

Figure 2-4. Cyclotella meneghiniana

Figure 2-5. Cyclotella cf. atomus var. gracilis

Figure 2-6. Cyclotella sp.1.

Figure 2-7. Diploneis puella 

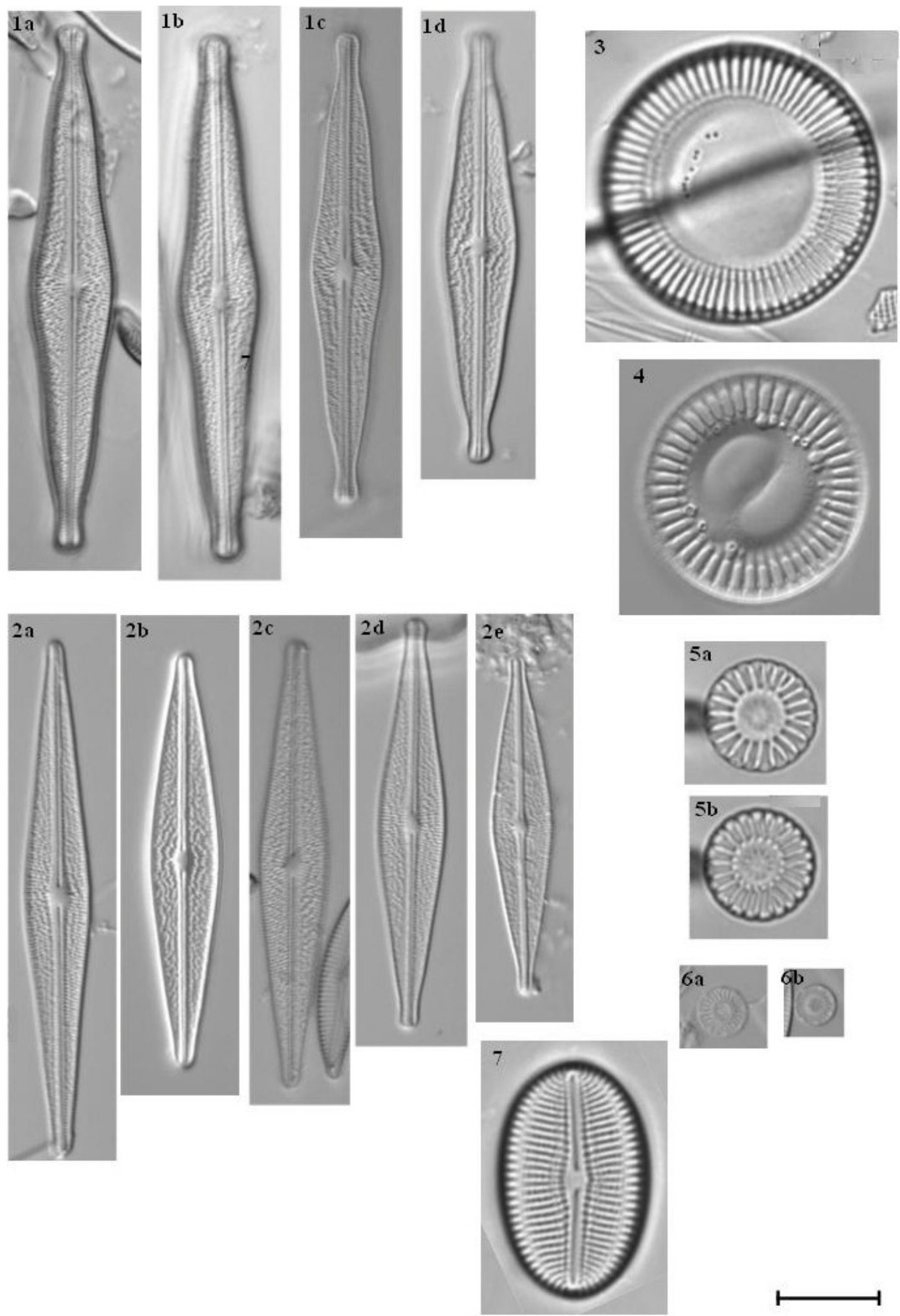
Plate 3. Figures 3-1 through 3-4

Figure 3-1. Navicula cf. radiosa

Figure 3-2. Navicella pusilla

Figure 3-3. Frustulia rhomboides var. crassinervia.

Figure 3-4. Navicula cryptotenella 

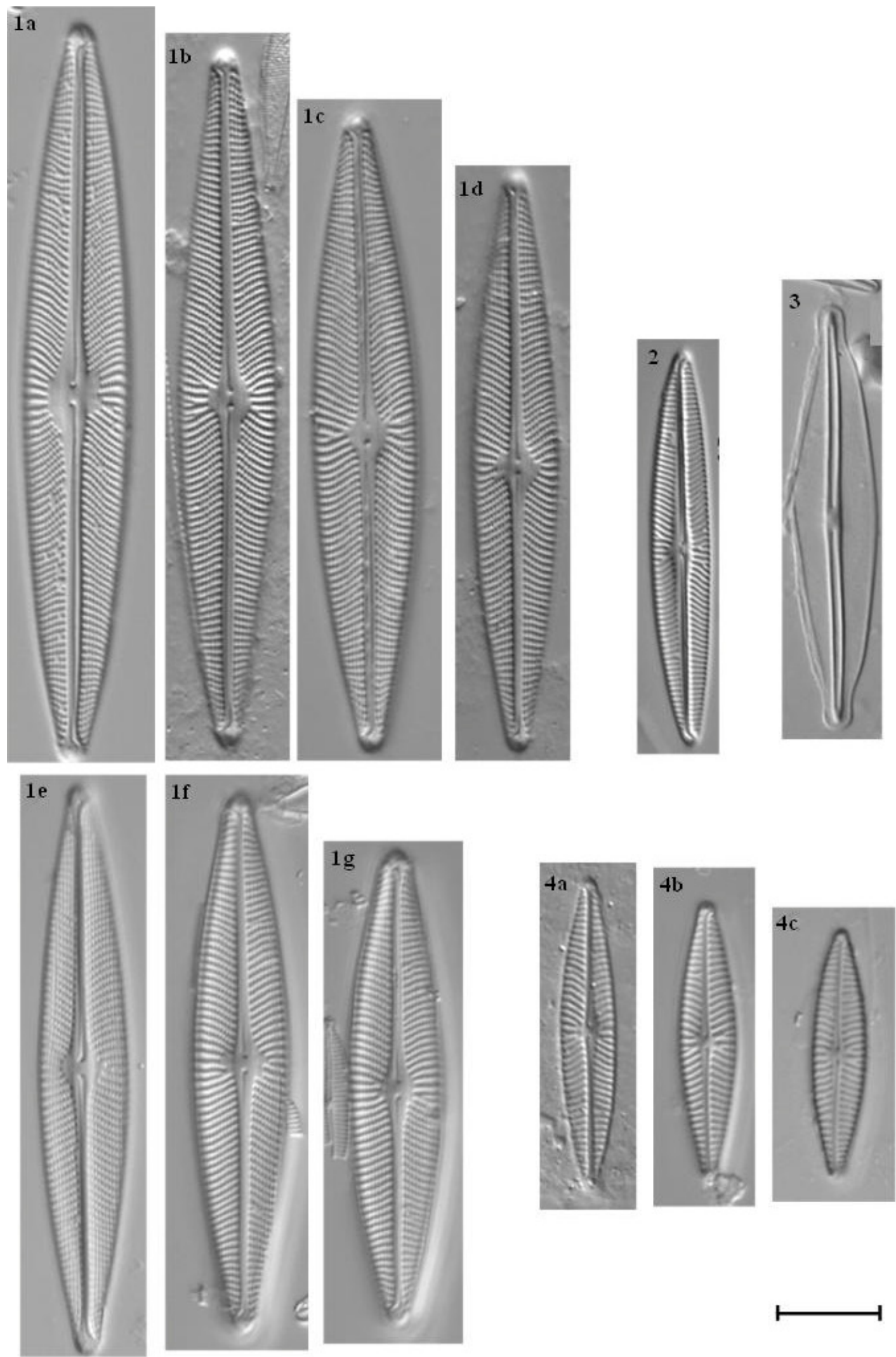
Plate 4. Figures 4-1 through 4-14

Figure 4-1. Neidium ampliatum

Figure 4-2. Neidium ampliatum

Figure 4-3. Encyonema evergladianum

Figure 4-4. Stauroneis pachycephala

Figure 4-5. Encyonopsis microcephala

Figure 4-6. Proschkinia sp.1

Figure 4-7. Caponea caribbea

Figure 4-8. Caloneis sp.1

Figure 4-9. Caloneis sp.1

Figure 4-10. Caloneis sp.2

Figure 4-11. Caloneis sp.3

Figure 4-12. Navicula constans

Figure 4-13. Navicula subtilissima

Figure 4-14. Encyonopsis subminuta 

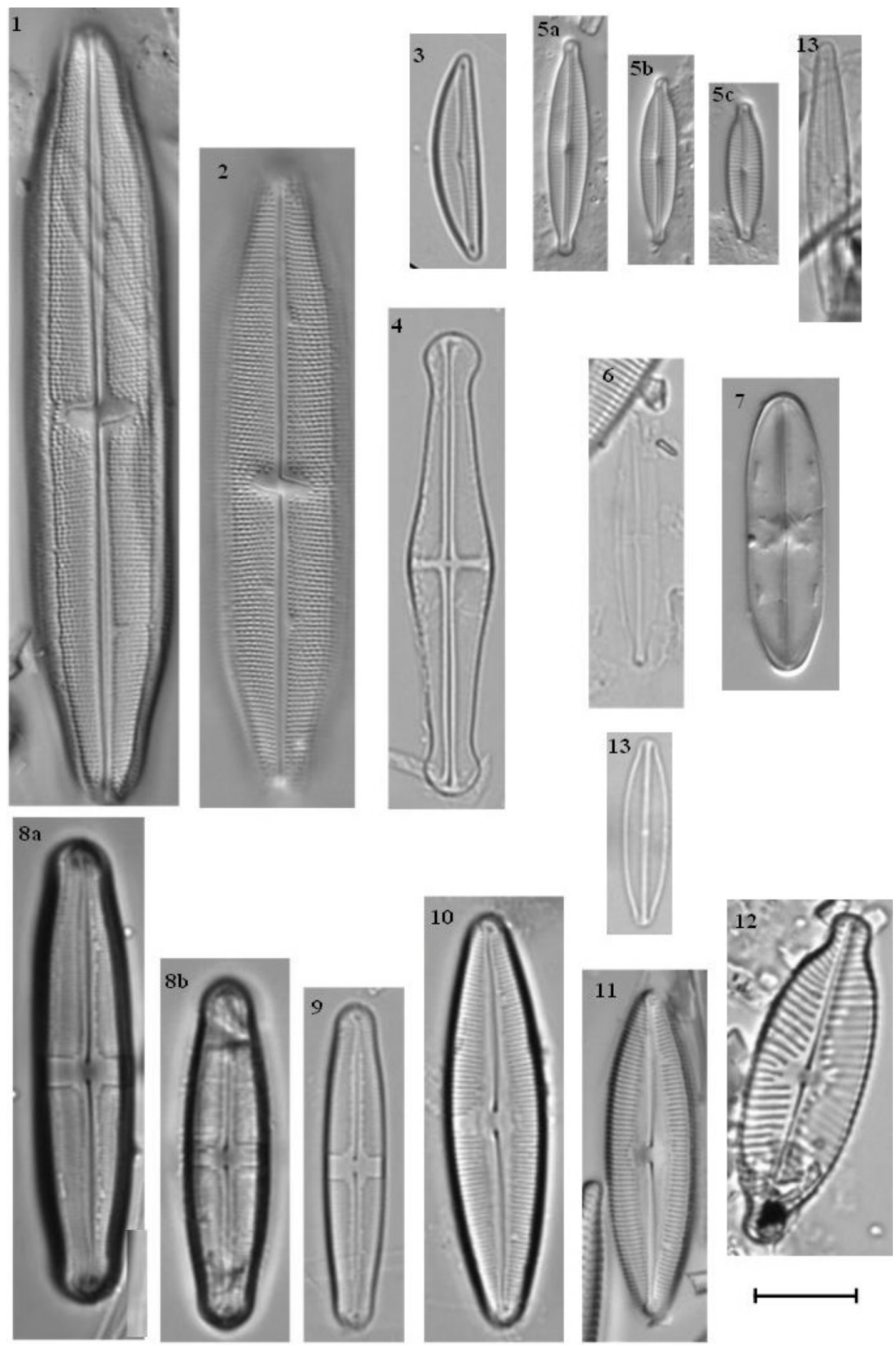
Plate 5. Figures 5-1 through 5-7

Figure 5-1. Tabularia tabulata

Figure 5-2. Fragilaria synegrotesca

Figure 5-3. Fragilaria (?) sp.1 cf. famelica

Figure 5-4. Fragilaria capucina var. vaucheriae

Figure 5-5. Staurosira construens

Figure 5-6. Diploneis sp.1

Figure 5-7. Diploneis sp.2 

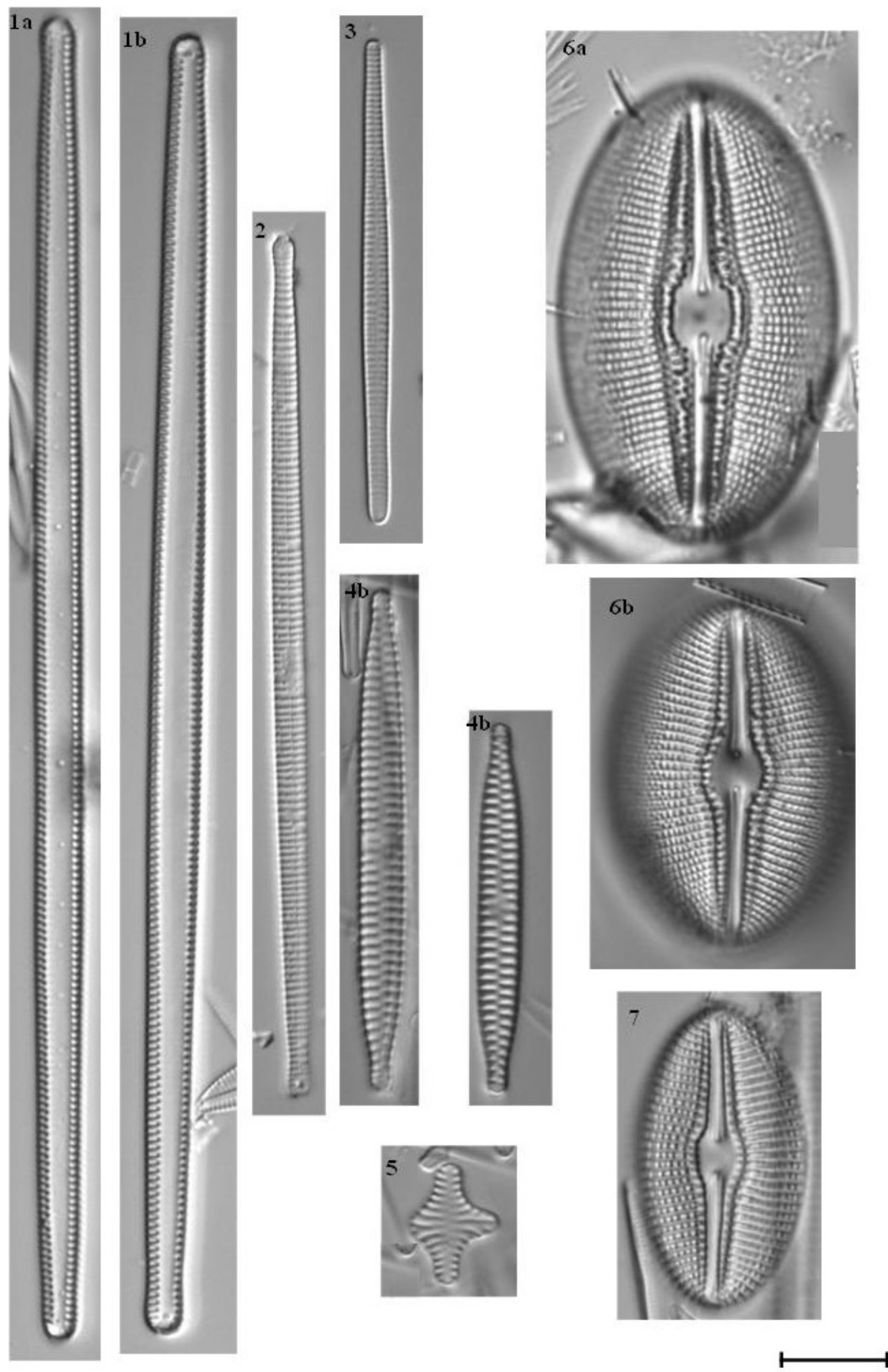
Plate 6. Figures 6-1 through 6-11

Figure 6-1. Nitzschia scalaris

Figure 6-2. Nitzschia serpentiraphe

Figure 6-3. Nitzschia linearis var. subtilis

Figure 6-4. Nitzschia linearis var. subtilis

Figure 6-5. Nitzschia palaea

Figure 6-6. Nitzschia palaea

Figure 6-7. Nitzschia microcephala

Figure 6-8. Nitzschia sp.1

Figure 6-9. Nitzschia denticula

Figure 6-10. Nitzschia semirobusta

Figure 6-11. Nitzschia amphibia 

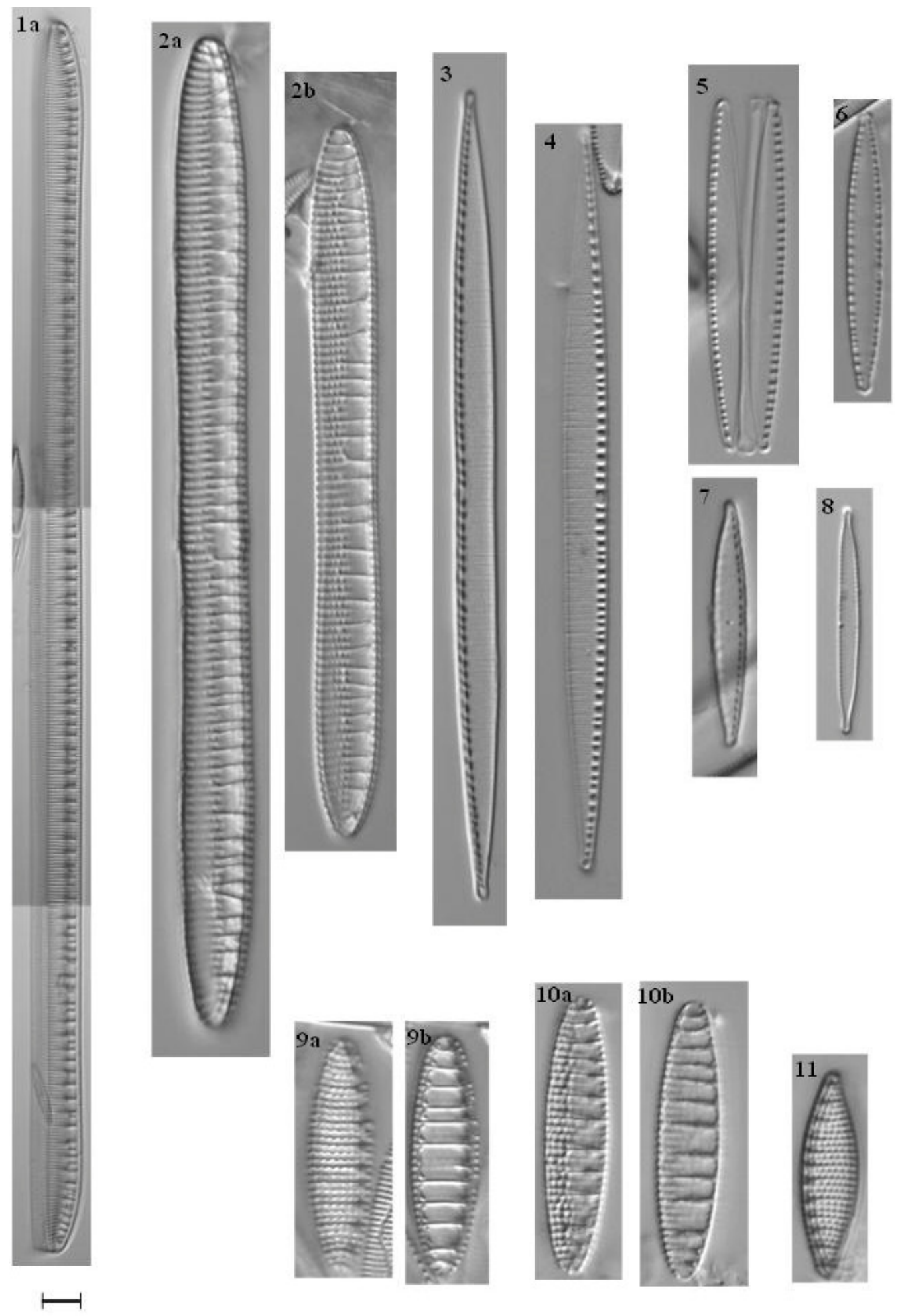
Plate 7. Figures 7-1 through 7-6

Figure 7-1. Diploneis cf. elliptica var. tropica

Figure 7-2. Diploneis parma

Figure 7-3. Diploneis sp.5

Figure 7-4. Diploneis sp.6

Figure 7-5. Diploneis ovalis

Figure 7-6. Diploneis oblongella 

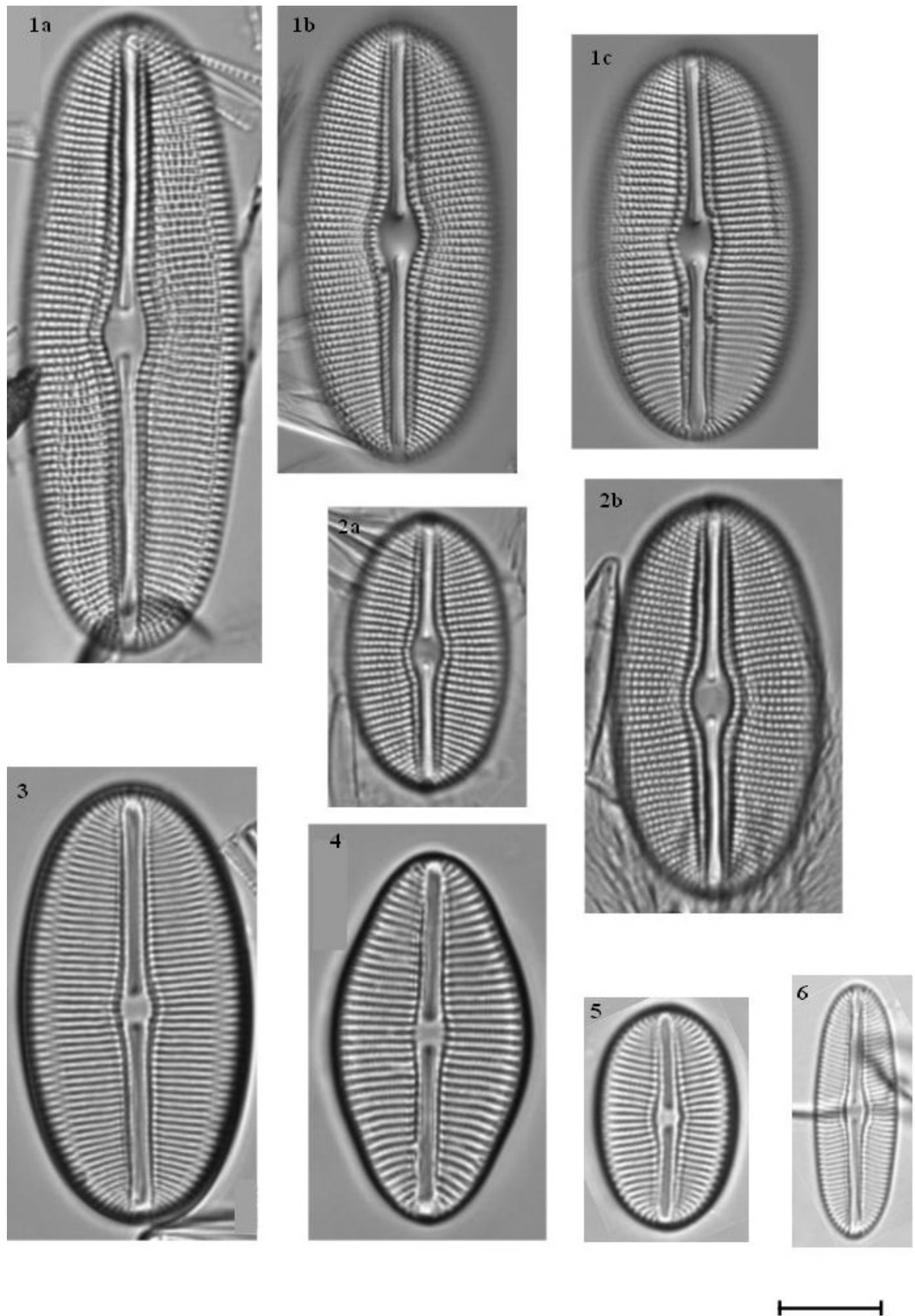
Plate 8. Figures 8-1 through 8-10

Figure 8-1. Gomphonema cf. vibriodes

Figure 8-2. Gomphonema intricatum var. vibrio

Figure 8-3. Gomphonema gracile

Figure 8-4. Gomphonema affine

Figure 8-5. Fallacia pygmaea

Figure 8-6. Navicula pseudocressirostris

Figure 8-7. Navicula palistinae

Figure 8-8. Mastogloia smithii var. lacustris

Figure 8-9. Mastogloia smithii

Figure 8-10. Gomphonema parvulum 

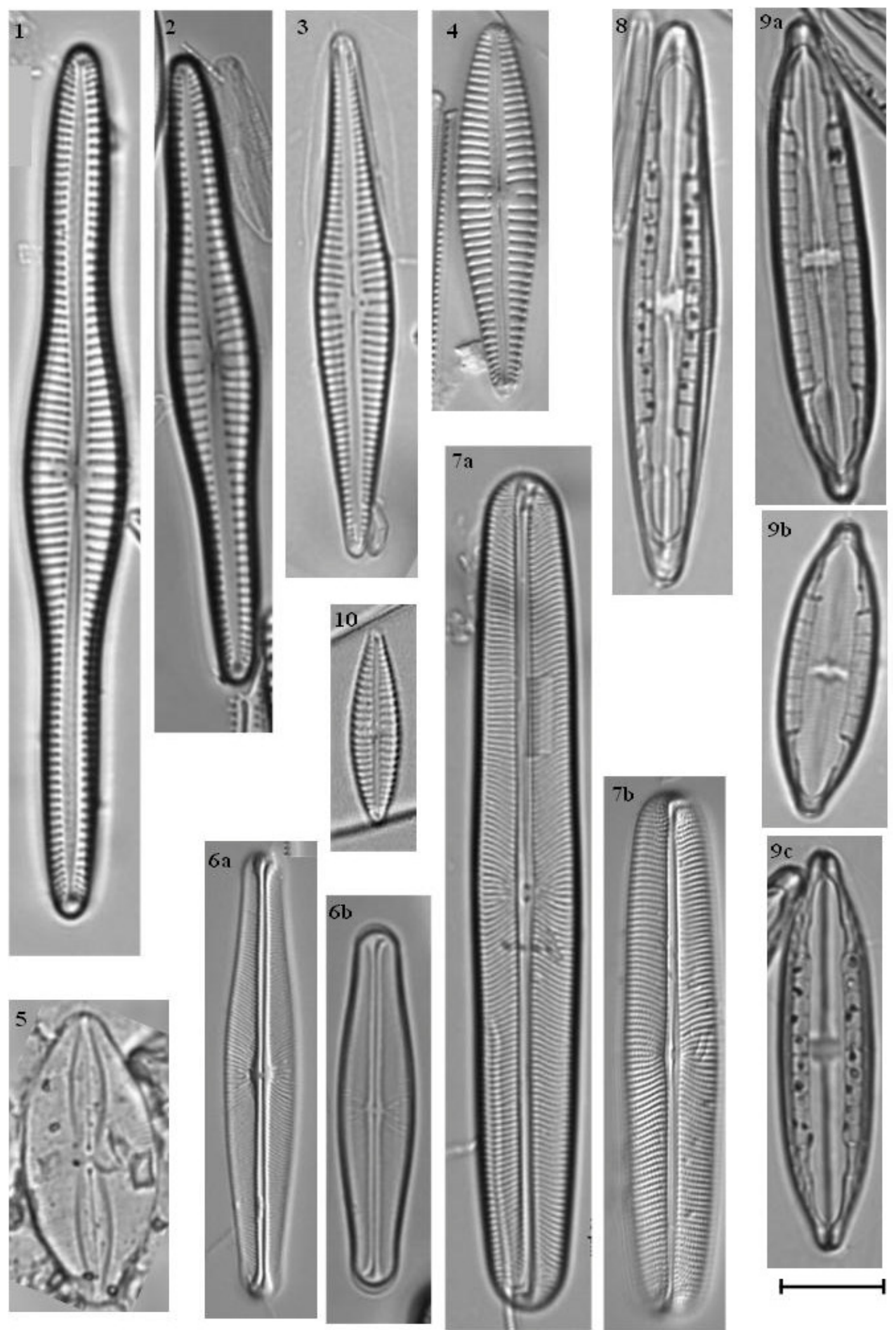
Plate 9. Figures 9-1 through 9-13

Figure 9-1. Pinnularia cf. neomajor var. inflata

Figure 9-2. Pinnularia sp.4

Figure 9-3. Pinnularia sp.1

Figure 9-4. Pinnularia tropica

Figure 9-5. Pinnularia sp.2

Figure 9-6. Pinnularia stoermeri

Figure 9-7. Pinnularia divergens

Figure 9-8. Pinnularia microstauron

Figure 9-9. Pinnularia sp.5

Figure 9-10. Pinnularia acrosphaeria

Figure 9-11. Pinnularia stoermeri

Figure 9-12. Pinnularia sp.7

Figure 9-13. Pinnularia pisciculus var. angusta 

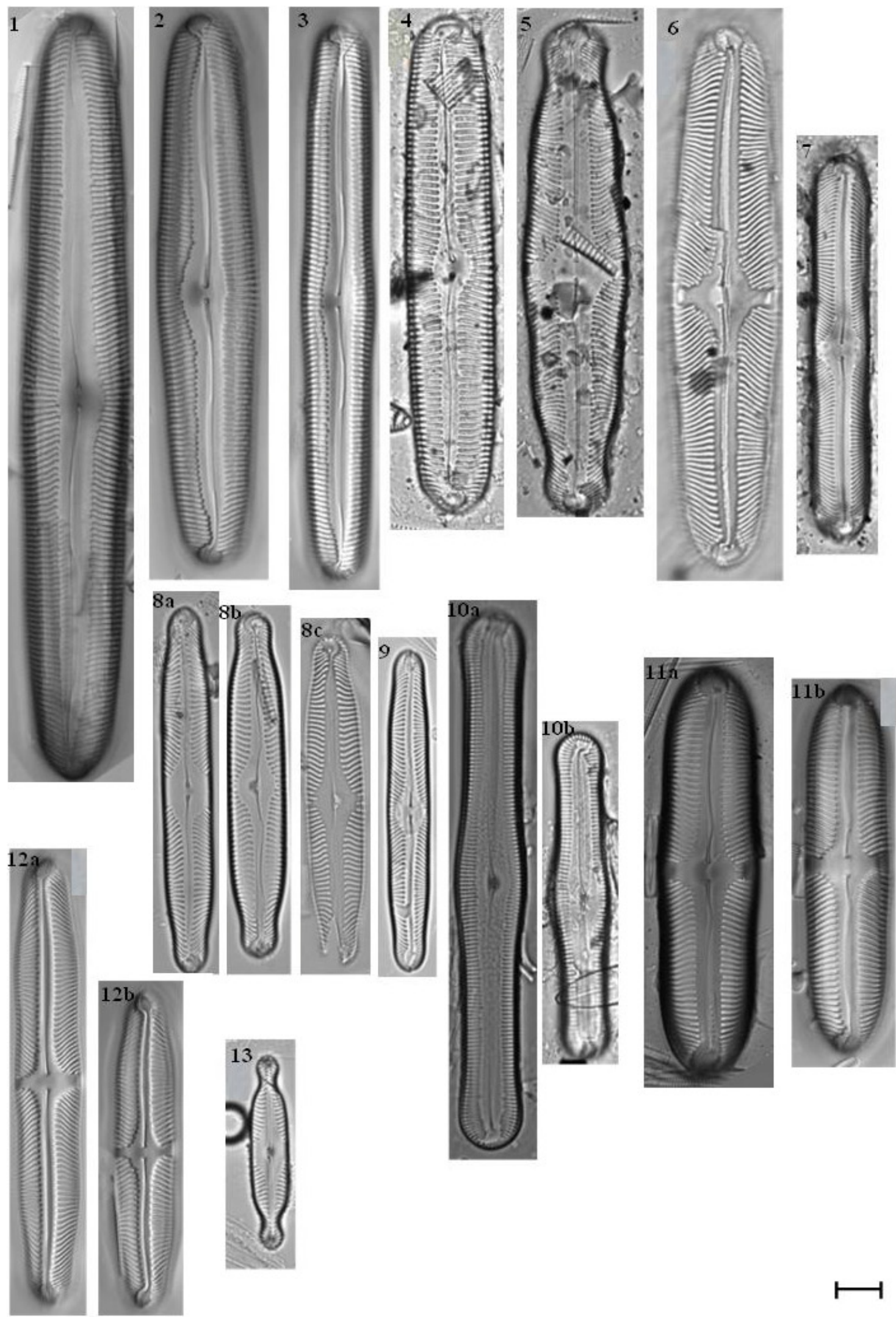
Plate 10. Figures 10-1 through 10-10

Figure 10-1. Surrirella elegans f. elongata

Figure 10-2. Hantzschia cf. elongata

Figure 10-3. Cymbella aspera

Figure 10-4. Hantzschia cf. vivacior

Figure 10-5. Hantzschia spectabilis

Figure 10-6. Nitzschia acicularis

Figure 10-7. Nitzschia lacunarum

Figure 10-8. Stenopterobia curvula

Figure 10-9. Nitzschia nana

Figure 10-10. Nitzschia thermalis var. minor 

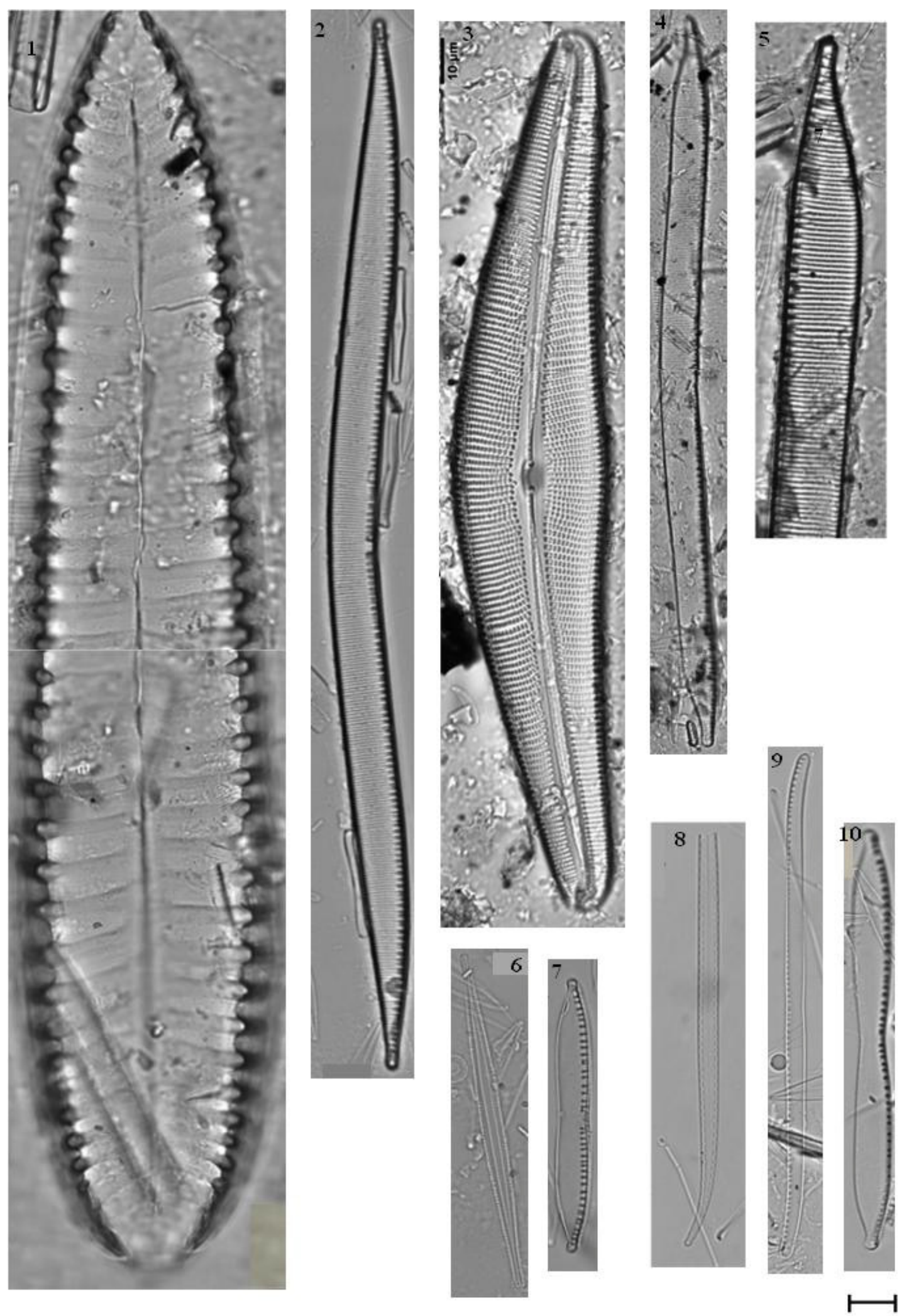
Plate 11. Figures 11-1 through 11-3

Figure 11-1. Pleurosigma sp.1

Figure 11-2. Craticula cuspidata

Figure 11-3. Stauroneis phoenicentron 

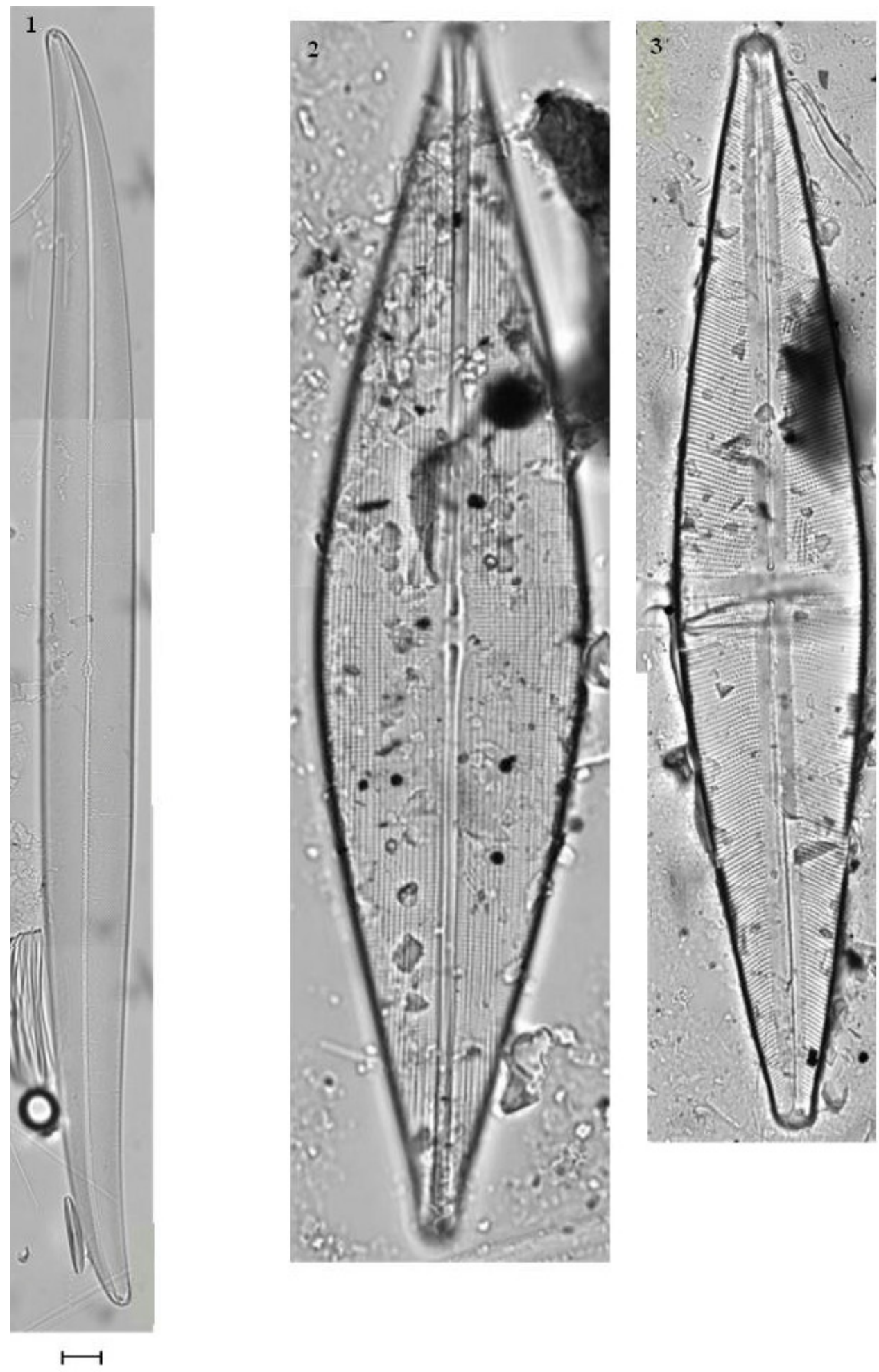
Plate 12. Figures 12-1 through 12-5

Figure 12-1. Plagiotropis sp.1

Figure 12-2. Parlibellus sp.1

Figure 12-3. Craticula sp.1

Figure 12-4. Rhopalodia gibba

Figure 12-5. Actinocyclus normanii 

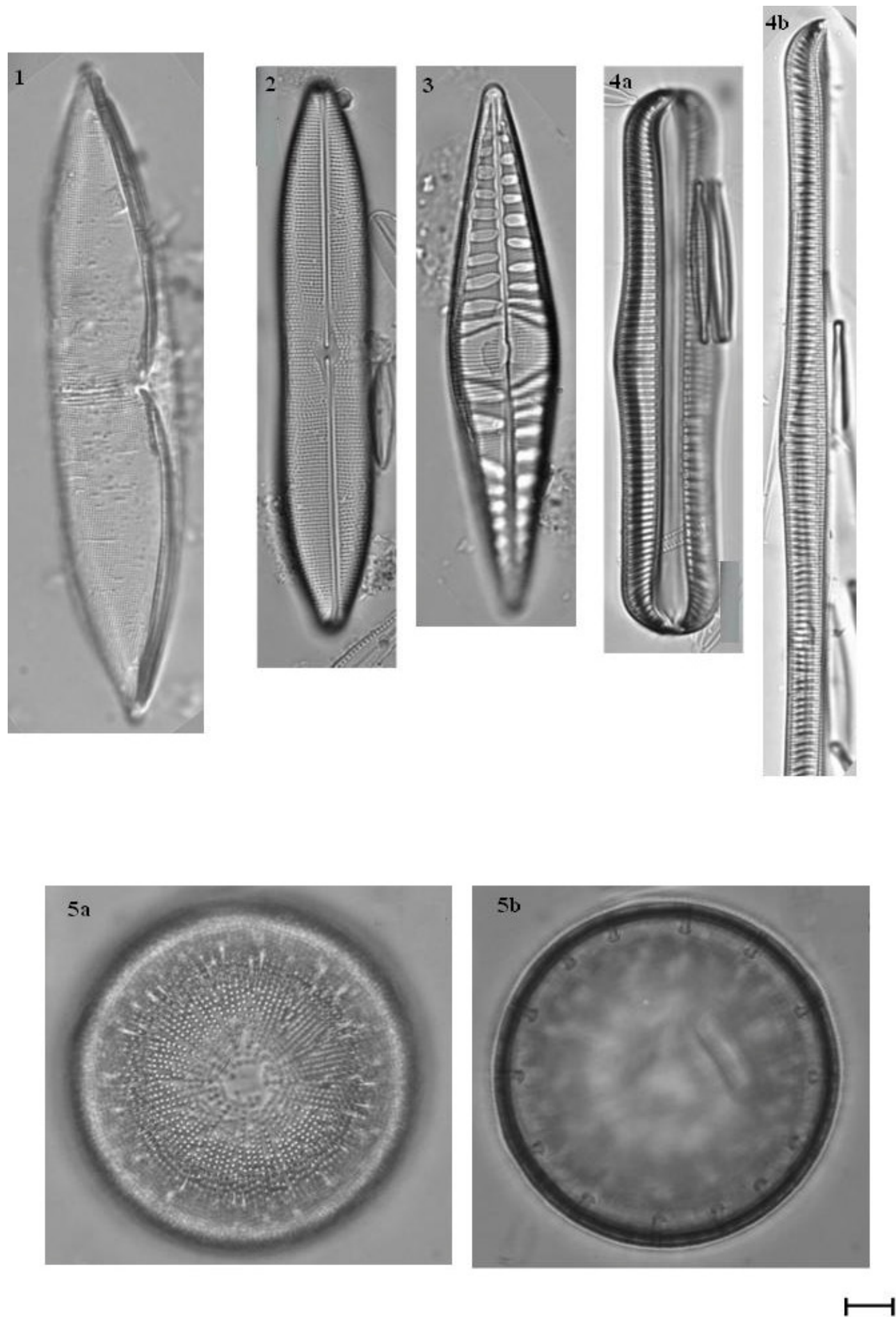
Plate 13. Figures 13-1 through 13-9

Figure 13-1. Anomoneis sphaerophora

Figure 13-2. Anomoneis sphaerophora forma?

Figure 13-3. Navicula brasiliana

Figure 13-4. Mastogloia braunii

Figure 13-5. Mastogloia elliptica var. dansei

Figure 13-6. Mastogloia lanceolata

Figure 13-7. Mastogloia braunii

Figure 13-8. Sellaphora pupula

Figure 13-9. Mastogloia elliptica 

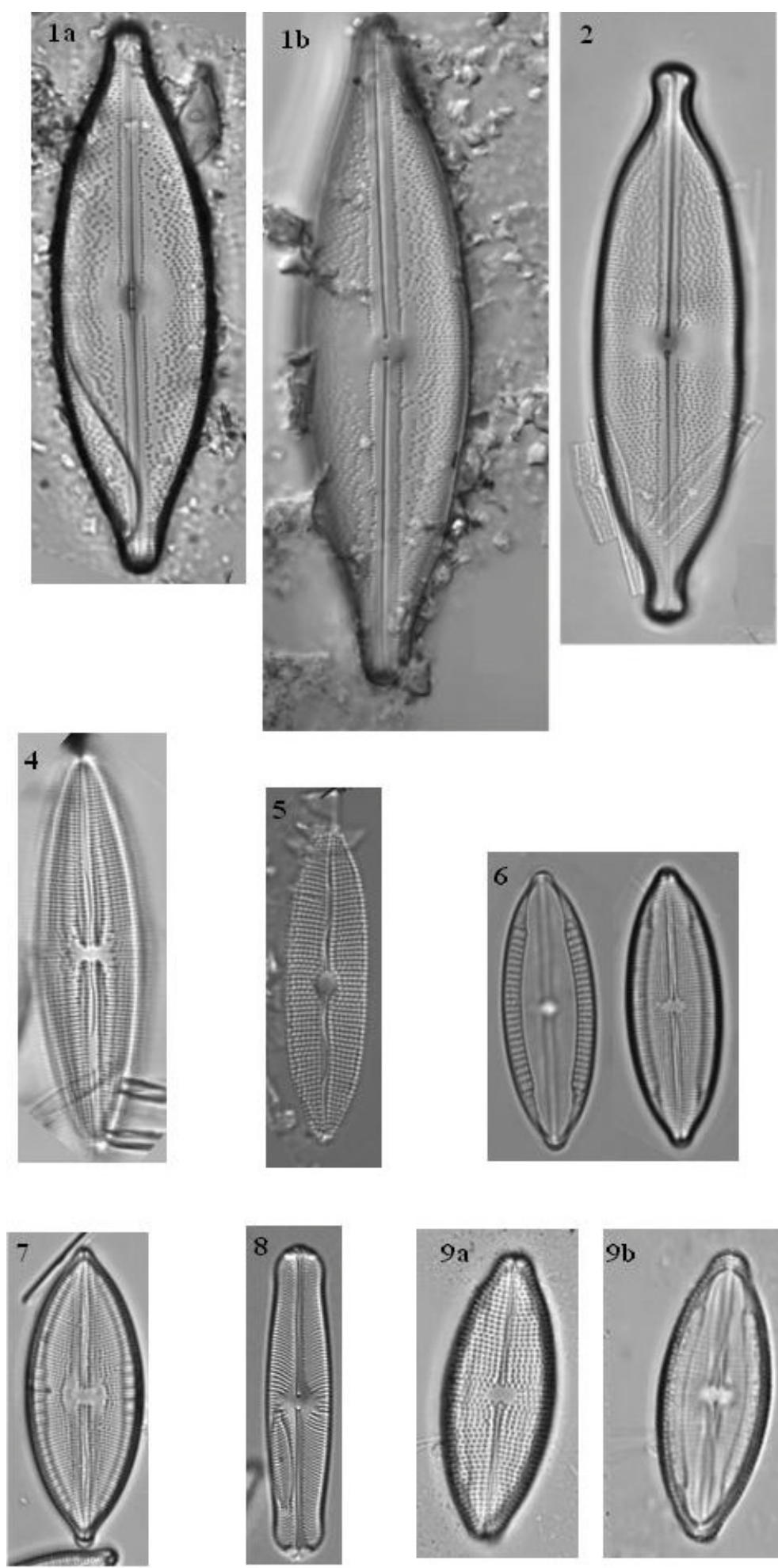
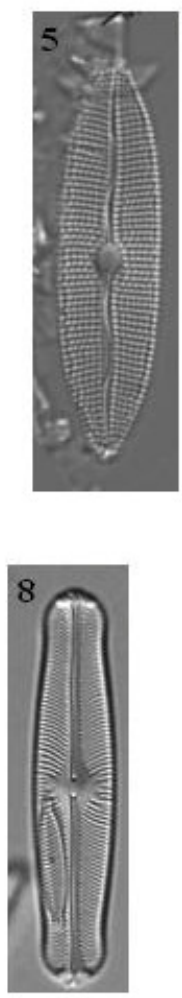

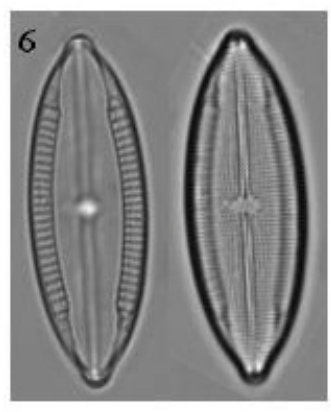

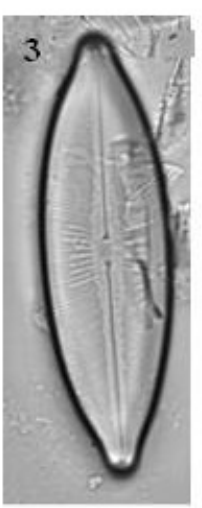
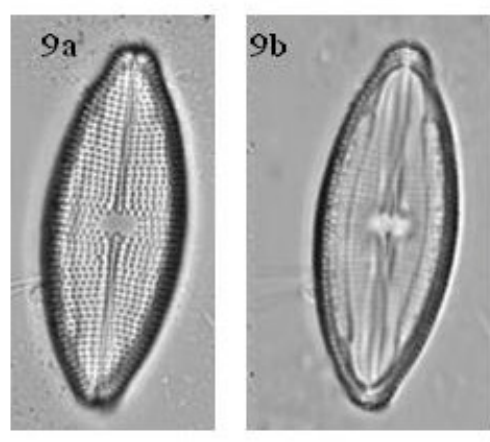
Plate 14. Figures 14-1 through 14-7

Figure 14-1. Encyonema vulgare var. vulgare

Figure 14-2. Encyonema silesiacum

Figure 14-3. Encyonema jemtlandicum var. venezolanum

Figure 14-4. Encyonema jemtlandicum var. venezolanum

Figure 14-5. Encyonema sp.1

Figure 14-6. Encyonema sp.2

Figure 14-7. Encyonema sp.3 

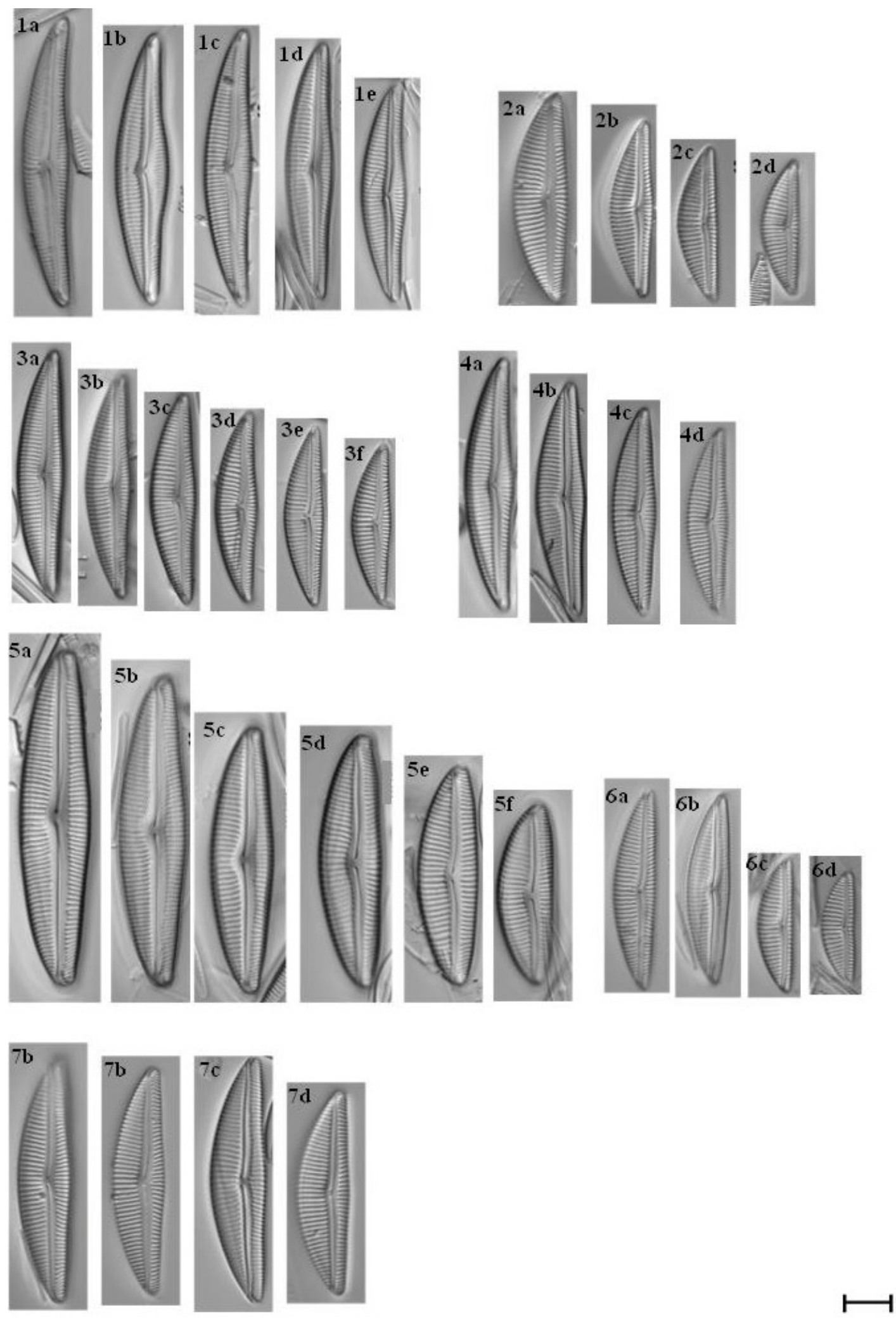
Plate 15. Figures 15-1 through 15-12

Figure 15-1. Eunotia rabenhorstiana var. elongata

Figure 15-2. Eunotia cf. karenae

Figure 15-3. Eunotia cf. monodon

Figure 15-4. Eunotia naegelii

Figure 15-5. Eunotia flexuosa

Figure 15-6. Eunotia sp.1

Figure 15-7. Eunotia implicata

Figure 15-8. Eunotia sp.2

Figure 15-9. Eunotia camelus

Figure 15-10. Eunotia sp.3

Figure 15-11. Eunotia botuliformis

Figure 15-12. Eunotia cf. yberai 

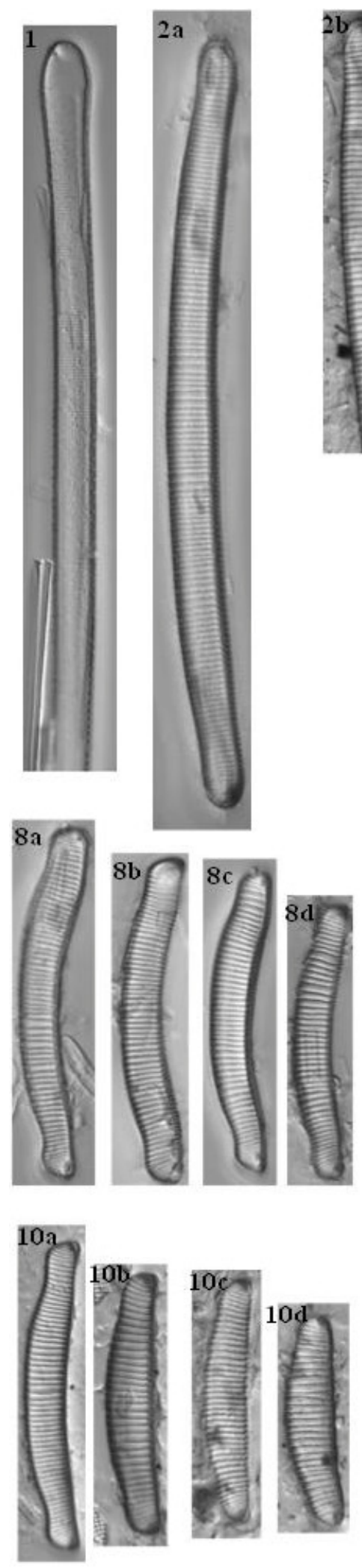
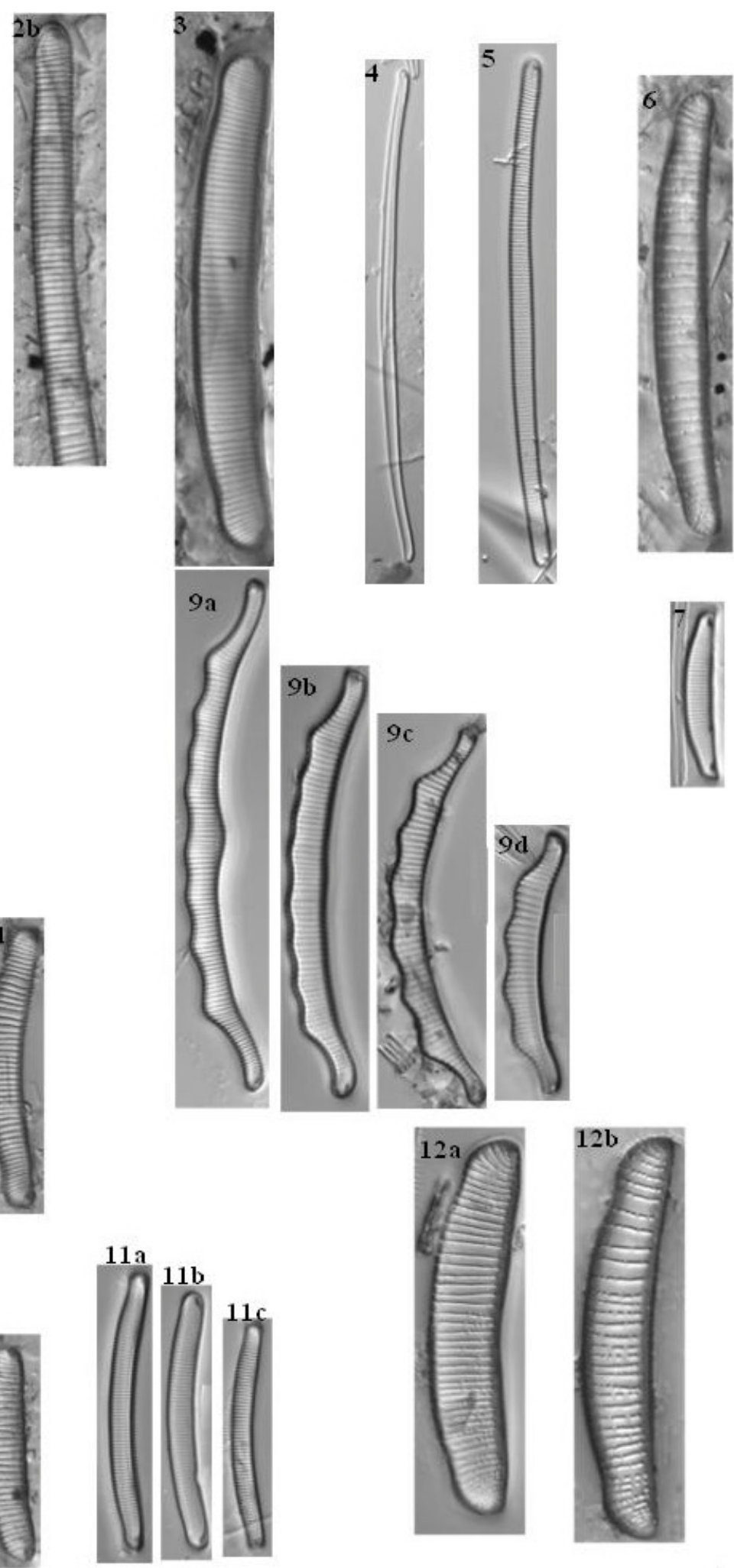

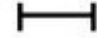


Plate 16. Figures 16-1 through 16-5

Figure 16-1. Fragilaria ulna var. ulna

Figure 16-2. Fragilaria cf. ulna

Figure 16-3. Synedra acus var. angustissima

Figure 16-4. Epithemia sp.1

Figure 16-5. Diploneis sp.7 

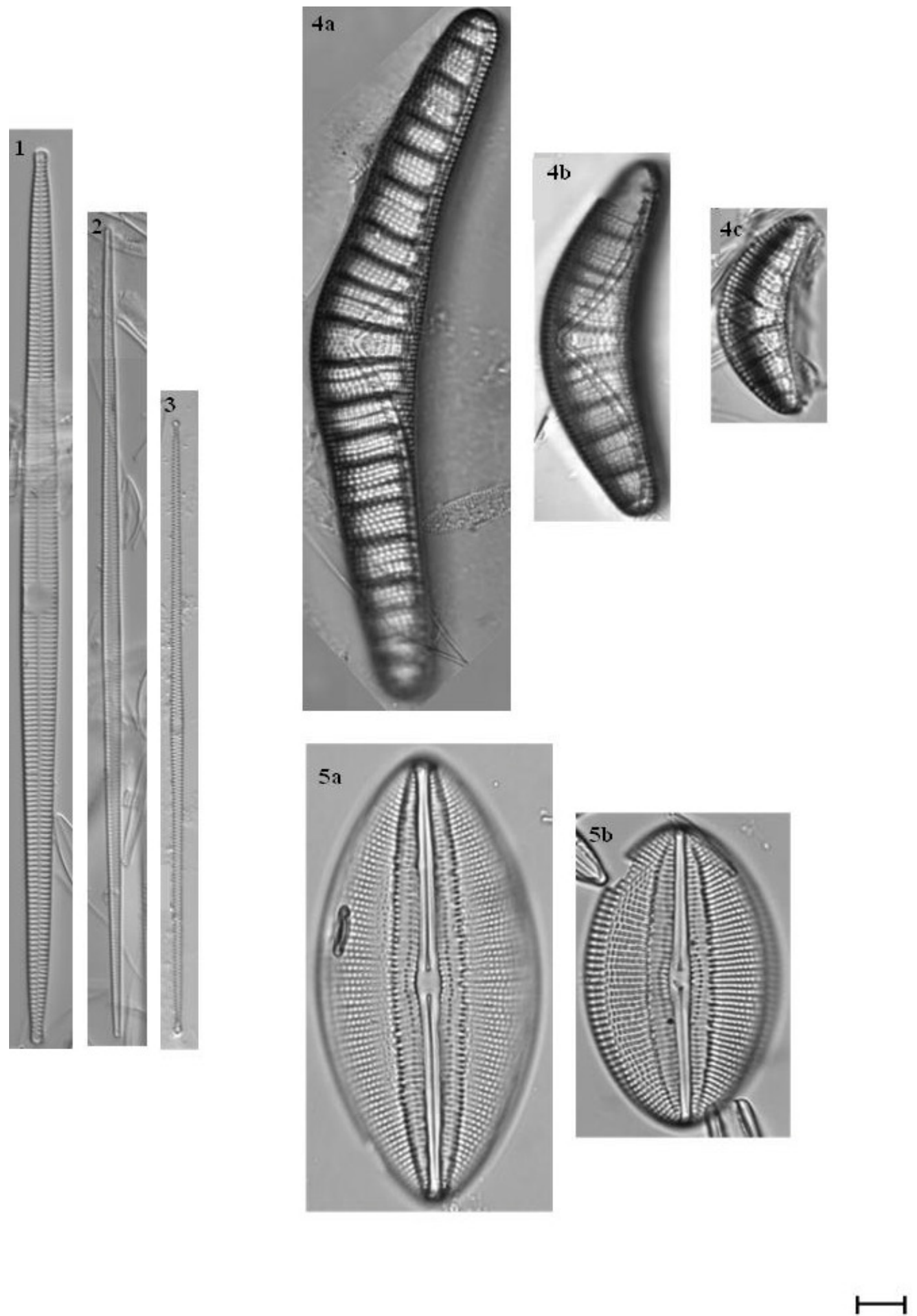
Plate 17. Figures 17-1 through 17-11

Figure 17-1. Amphora pseudoproteus

Figure 17-2. Amphora sp.1

Figure 17-3. Amphora sp.2

Figure 17-4. Amphora sp.3

Figure 17-5. Seminavis eulensteinii

Figure 17-6. Nitzschia obtusa var. kurzii

Figure 17-7. Amphora sp.4

Figure 17-8. Amphora copulata

Figure 17-9. Amphora corpulenta var. capitata

Figure 17-10. Amphora cymbifera var. heritierarum

Figure 17-11. Amphora sulcata 

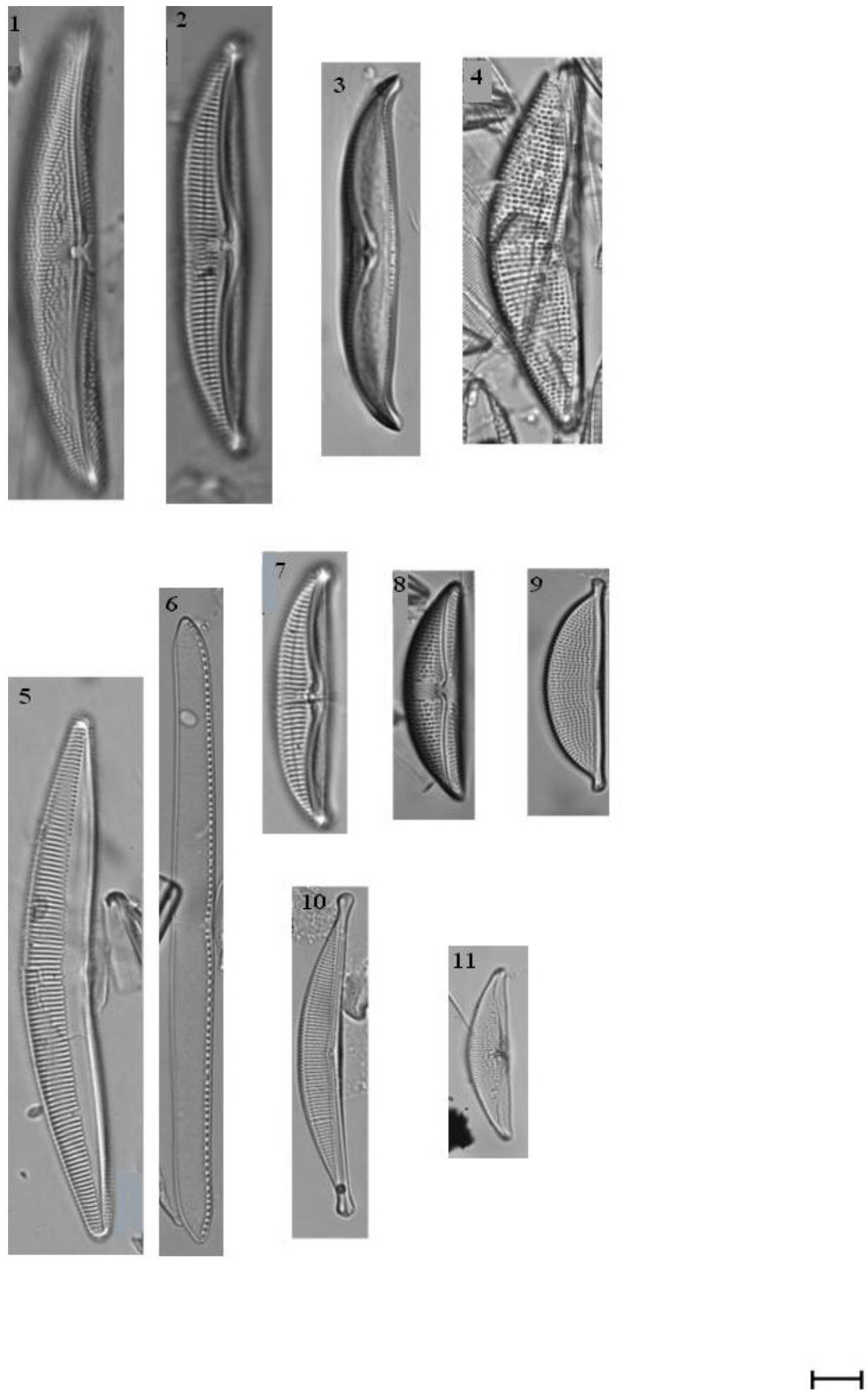


\title{
CHAPTER IV
}

Periphytic diatom assemblages as indicators of water quality in the Everglades and three tropical karstic wetlands

\begin{abstract}
Within the Everglades, periphyton mat total phosphorus (TP) is the best metric for detecting phosphorus $(\mathrm{P})$ enrichment and periphytic diatom assemblages are effective indicators of water quality change. In this study, relationships between diatom assemblages and water quality were investigated in three Caribbean karstic wetlands and cross system diatom inference models were assessed. Periphyton mat TP and diatom assemblage data were generated from samples collected in karstic wetland habitats in Belize, Mexico and Jamaica. Ordination and weighted-averaging modeling techniques were used to examine relationships between periphyton mat TP concentrations and diatom assemblages among the locations. Diatom assemblages changed in relation to periphyton mat TP concentrations, such that "low" and "high" TP assemblages could be identified. Species TP optima and indicator species differed between Everglades and Caribbean locations, however weighted averaging models effectively predicted mat TP concentrations from diatom assemblages for both Everglades $\left(\mathrm{R}^{2}=0.56\right)$ and Caribbean $\left(\mathrm{R}^{2}=0.85\right)$ locations. This study demonstrates the effectiveness of diatoms as indicators of water quality in Caribbean karstic wetlands. However, the cross system application of diatom based inference models should be employed with caution, as variations in the response of species to water quality reduces the accuracy of model based predictions.
\end{abstract}




\section{INTRODUCTION}

Much of the Caribbean and Central American region is underlain by ancient limestone bedrock (Eocene karst), which, where elevated from the ocean can contain isolated, riverine or tidal freshwater depression wetlands. These wetlands are characterized by low concentrations of water column nutrients and a distinctive biological community, particularly an abundance of thick, calcareous benthic periphyton mats (Rejmánková and Komárková, 2000; Novelo and Tavera, 2003; Gaiser et al., 2006; La Hée et al., in prep). Because these wetlands are naturally depleted in nutrients, enhanced supplies coming from surface water runoff from agricultural and industrial activities and altered groundwater interactions have long-lasting cascading ecosystem effects (Hagerthey et al., 2009) that begin with the microbial community (Gaiser et al., 2005). Tools providing an early warning of these changes are valuable, as remediation practices can be established prior to a new hysteretic state is reached (Hagerthey et al., 2009). Water column concentration of dissolved or total nutrients is not a useful metric of enrichment history due to high rates of abiotic adsorption and biotic assimilation, even as communities are irrevocably altered when exposed to even low-level increases in nutrient load (Gaiser et al., 2005).

Most science on nutrient-induced state changes in karstic wetlands has taken place in the Florida Everglades, an expansive $5,000 \mathrm{~km}^{2}$ subtropical wetland that has been exposed to decades of enrichment resulting mainly from agricultural development and runoff in the upstream drainage (Willard et al., 2001; Winkler et al., 2001). Experiments and observations along enrichment gradients developed downstream of 
canal inflows have demonstrated that plant productivity is limited by phosphorus (McCormick and O’Dell; McCormick et al., 1996), and that very low supplies ( $<5$ ug L $\mathrm{L}^{-1}$ above ambient) can initiate a state change (Gaiser et al., 2005). Excess phosphorus added to natural ecosystems is removed within hours or days by microbial communities existing in periphyton, detritus and sediments (Noe et al., 2001), and together with adsorption to associated calcium carbonate (Scinto and Reddy, 2001), these communities maintain water column concentrations below 5-6 ug L-1 (Thomas et al., 2006), except in locations with a long history of enrichment (McCormick et al., 1996). Although $\mathrm{P}$ is efficiently removed by microbes it drives marked physiological, physical and compositional changes (McCormick and O'Dell, 1996; McCormick et al., 2001; Gaiser et al., 2005; Iwaniec et al., 2006; Munyon, 2010), and persistent increases later lead to changes in soil respiration, macrophyte growth and composition and consumer function (DeBusk et al., 2001; Reddy et al., 1993; Smith et al., 2009).

Native Everglades wetlands are noted for the presence of an abundance of benthic periphyton, referred to as "mats" due to their tendency to grow as attached masses on benthic, submerged and floating substrates (Van-Meter Kasanof, 1973; Browder, 1982; Figure 4-1). These mats can reach extreme standing crops and productivity within this system (Browder et al., 1994; Goldsborough and Robinson, 1996; Ewe et al., 2006; Gaiser, 2009), that regulates the production of detritus (Neto et al., 2006), supports the community of aquatic consumers (Williams and Trexler, 2006; Liston et al., 2008), contribute to gas flux (Munyon, 2010, McCormick et al., 1996, 1997) and influences soil quality through deposition of calcium carbonate throughout the system. Filamentous cyanobacteria (primarily Schizothrix spp. and Scytonema spp.) dominate the periphyton 
mat assemblage, forming an interwoven structure in which diatoms, green algae, desmids and heterotrophic bacteria grow amid polysaccharide mucilage strands and interstitial deposits of calcium carbonate (Van Meter-Kasanof, 1973; Swift and Nicholas, 1987; Donar et al., 2004; Stal, 2000). In addition to rapidly removing TP from the water column, periphyton mats also exhibit marked responses to increases in $\mathrm{TP}$, the most obvious being an anomalous decrease in overall mass and increase in organic content (Pan et al., 2000; McCormick et al., 2001; Gaiser et al., 2006). The response to increased TP is also echoed in the algal assemblage, with a loss of carbonate-precipitating cyanobacteria and a switch from an endemic diatom assemblage to one dominated by 'weedy' benthic taxa (Swift and Nicholas, 1987; Grimshaw et al., 1993; McCormick et al., 1996; McCormick and O’Dell, 1996; Pan et al., 2000). Because the diatom assemblage is particularly diverse and responsive to $\mathrm{P}$, diatom-based $\mathrm{P}$ inference models have been developed to infer water (Slate and Stevenson, 2007), soil (Cooper et al., 1999) and periphyton mat (Gaiser et al., 2006) TP levels, providing a more integrated understanding of P load history than these measurements do directly. Therefore, within the Everglades wetland system, periphytic diatom assemblages have proven to be a highly effective tool for monitoring water quality changes.

Recent studies have identified karstic wetlands within the Caribbean region, with marsh habitats and periphyton mats comparable to those found within the Everglades (Rejmánková, 2001; Novelo et al., 2007). In these wetlands, periphyton mat biomass is extremely high and shows a paradoxical negative relationship in response to $\mathrm{P}$ enrichment, a pattern which parallels that identified in the Everglades (La Hée et al., in prep). These wetlands have a less extensive history of enrichment compared to the 
Everglades, however, areas that have been subjected to agricultural and industrial activities exhibit significant changes in water quality and concomitant ecosystem degradation (Rejmánková and Komárková, 2005). The use of diatoms as bioindicators would be valuable in the management of these wetlands. The lack of environmental and species data across much of the region, however, precludes the development of site specific diatom inference models. (Rejmánková, 2001).

Under these circumstances, diatom TP inference models developed within the Everglades may be used to predict environmental changes within Caribbean wetlands. The cross-system application of calibration models has been used in other systems (Weilhoefer and Pan, 2006; Charles et al., 2006), as well as in palaeoecological work in which the response of modern diatom flora to present environmental conditions is used to infer past environmental conditions (Battarbee, 1986; Smol et al., 1986; Dixit et al., 1992b; Fritz et al., 1999). The use of cross system models is, however, contingent on the systems being environmentally similar, with an overlapping species assemblage that exhibits a parallel response to water quality change. It is currently not known whether the diatom community within these wetlands are the same as those within the Everglades or if they respond similarly to $\mathrm{P}$.

The main objectives of this study therefore aim to (i) examine periphytic diatom assemblages from karstic wetland habitats in Belize, Mexico and Jamaica, compare these to those found within similar wetland habitats in the Everglades and examine the relationship between periphyton mat TP levels and diatom assemblage at these locations, (ii) determine the feasibility of employing models relating diatom assemblage to water quality in the Everglades to similar systems within the wider Caribbean. 


\section{SITE DESCRIPTION}

Sampling was conducted in three wetland systems, similar with respect to geology, climate, hydrology and vegetation, located within the northern Caribbean Basin: the Sian Ka'an Biosphere Reserve (and areas to the south), in Quintana Roo, Mexico; the New River Lagoon in Orange Walk, Belize; and the Broad River, in the Black River Morass, St. Elizabeth, Jamaica (Figure 4-2, Table 4-1).

The Sian Ka'an Biosphere Reserve and the wetlands extending beyond its boundary to the south, encompass a $6500 \mathrm{~km}^{2}$ area along the south eastern coast of the Yucatan Peninsula in Quintana Roo, Mexico (Cairns et al., 2005). The Yucatan peninsula is an uplifted marine platform which extends from the greater Yucatan platform and serves as a divide between the Gulf of Mexico and the Caribbean Sea. The geological formation is a 2 to $3 \mathrm{~km}$ thick sequence dominated by limestone, with intermittent layers

of dolomite, anhydrite and gypsum (Weidie, 1985). The karstic wetland marshes located within the Yucatan region are dominated by low phosphorus, inland freshwater, marl based habitats and coastal mesohaline habitats. The most common freshwater macrophytic species include Cladium jamaicense (sawgrass), Eleocharis spp. (spikerush) and Typha domingensis (southern cattail), each of which tends to become dominant at low, intermediate and high water depths, respectively (Rejmánková et al., 1996). Dwarfed populations of Rhizophora mangle (red mangrove) become more abundant as salinity levels increase, and form the dominant tree species in the coastal brackish water marshes. Calcitic periphyton mats are abundant in both freshwater and brackish water habitats with marl substrates (Rejmánková et al., 1996). Inland sampling sites were 
confined to freshwater, Eleocharis spp. Marshes, and closer to the coast, brackish water sites dominated by dwarf Rhizophora mangle were sampled.

The New River Lagoon, located in the district of Orange Walk to the north of Belize, is an approximately $23 \mathrm{~km}$ long and $750 \mathrm{~m}$ wide stretch of the New River, which is the longest river contained entirely within Belize (Meerman, 2006). The area lies just to the southeast of the basal portion of the Yucatan peninsula and exhibits geological features similar to the adjacent landmass (Weidie, 1985). The New River Lagoon is flanked by marshes dominated mainly by Cladium jamaicense, Eleocharis cellulosa and Eleocharis interstincta, with intermittent deeper pools supporting dense assemblages of Nymphea ampla (dotleaf waterlilly). Sampling sites in this area were again confined to Eleocharis spp. marshes adjacent to the lagoon.

The Black River Morass encompasses the largest wetland and river system within the Greater and Lesser Antillean archipelago (Davis et al., 1998; Massa and HaynesSutton, 1998). It lies within the Black River Basin, which occupies an area of approximately $1,488 \mathrm{~km}^{2}$ in the south-western region of Jamaica. The area is divided into two main sections: the Upper and Lower Morass. The Upper Morass is approximately $97 \mathrm{~km}^{2}$ (Cronberg, 1983) and is composed of a mass of swampy lowlands with limestone bedrock covered by peat deposits. The Lower Morass which is approximately $57 \mathrm{~km}^{2}$ (Enell, 1984), exists as an area of down-faulted, poorly karstified limestone, overlain by a relatively thin clay and peat sequence. Inland marsh areas display mixed vegetation dominated by Cladium jamaicense and Eleocharis spp., with large stands of Typha domingensis being present in some areas (Azan and Webber, 2007). Closer to the coast, assemblages dominated by Rhizophora mangle are prevalent 
and these trees can also be found bordering the main waterways as they meander through the wetland system. Sampling sites were located within Cladium jamaicense and Eleocharis marshes bordering the Broad River, a major tributary of the Black River.

Data collected from these wetlands were then compared to a larger dataset collected from a total of 134 sites within the Everglades National Park, in southern Florida, U.S.A. The Everglades freshwater wetland system encompasses an area covering approximately $5,000 \mathrm{~km}^{2}$, and is one of the largest contiguous wetland systems in the North America (McCormick et al., 1998; Childers et al., 2001). The system is geologically young, having formed less than 5,000 years ago as a result of extended hydroperiod regimes that encouraged the deposition of peat and marl in the midst of a limestone depression (Gleason and Stone, 1994). The vegetation structure of the Everglades marsh habitats is similar to that of the previously described sites, with Cladium jamaicense and Eleocharis spp. marshes being common and Nymphaea odorata (American white waterlilly), Nymphaea aquatica (water shield) and Nuphar advena (spatterdock) characterizing deeper slough areas (Gunderson, 1994; Richardson, 2009). For this study, the data utilized were drawn from a large dataset derived from multiple seasonal sampling events conducted throughout the Everglades as part of the Comprehensive Everglades Restoration Plan (CERP, 2005; Gaiser, 2009).

\section{METHODS}

Each of the Caribbean study locations was visited on two occasions; once during a wet period and once during a dry period. As a result of abnormal seasonal rainfall 
patterns during the study period, wet and dry periods did not necessarily coincide with the typical regional wet and dry seasons. "Wet" and "dry" designations were therefore applied based on rainfall levels at each location during the sampling period, relative to typical wet and dry seasonal rainfall levels. The Everglades samples were collected during October to December, 2005 (Wet period) and September to December, 2006 (Dry period) as part of the periphyton component of the CERP seasonal sampling regime. The Mexico sites were visited in December 2006 (Wet period) and March 2008 (Dry period), the Belize sites in May 2007 (Dry period) and November 2007 (Wet period), and the Jamaica sites in December, 2007 (Wet period) and May 2008 (Dry period). Efforts were made to conduct sampling at as many sites as possible, however during dry periods the number of sites sampled varied according to the ability to locate areas that sustained water levels greater than $5 \mathrm{~cm}$. During wet periods, sampling efforts were contingent on the ability to gain access to sites, and were then limited to sites that did not exceed water depths of approximately $1 \mathrm{~m}$.

At each location, sampling sites were limited to three main types of wetland areas: (i) marshes dominated by Eleocharis spp. and/or Nymphaea spp., (ii) marshes dominated by Cladium jamaicense and (iii) swamps dominated by dwarf Rhizophora mangle. At each site, GPS coordinates were recorded and sampling was then conducted using a $1-\mathrm{m}^{2}$ throw trap to delineate a $1-\mathrm{m}^{2}$ area which was treated as a sample plot (Kushlan, 1981). Periphyton mat samples were collected from four plots at each site. At each plot a photograph was taken to record the surface view, and water depth, $\mathrm{pH}$ and conductivity were recorded. Periphyton mat material was then collected by hand, placed onto a seine net and coarsely sorted to remove animals, plant material and marl. A subsample of 120 
$\mathrm{ml}$ was removed from the periphyton material, placed in a sterile sample bag and stored in a cooler with ice for transport to the lab. When no observable calcitic periphyton mats were present, epipelon was sampled from the benthos and epiphytic films were scraped from any macrophytes present.

In the laboratory, each sample was transferred to a clean 500-ml beaker to which an additional $20 \mathrm{ml}$ of distilled water was added to facilitate homogenizing. From the homogenized total volume, a 50-ml sub-sample was removed, poured into a labelled 120$\mathrm{ml}$ sample cup and placed in a drying oven at $80^{\circ} \mathrm{C}$ until completely dry. The dried contents were then ground using a mortar and pestle and analyzed for TP following the methods of Solórzano and Sharp (1980). An additional 10-ml sub-sample was removed and processed for quantitative diatom analysis, using the sulphuric acid oxidation method of Hasle and Fryxell (1970). A measured amount of cleaned/processed material was then pipetted unto a glass coverslip and permanently fixed to a glass slide using Naphrax ${ }^{\circledR}$ mounting medium. Diatom species were identified using standard available taxonomic reference sources (See Dissertation Chapter 3) and a minimum of 500 diatom valves were counted along random transects on each slide at a magnification of X 1000, using a Nikon Eclipse E600 ${ }^{\circledR}$ compound light microscope.

Maximum, minimum and average values for water depth, $\mathrm{pH}$ and conductivity were calculated separately for wet and dry periods for each location. No conductivity and $\mathrm{pH}$ values were available for the Everglades sites for the period during which samples were collected. The values herein presented were instead derived from data recorded from the same sites during the CERP 2008 wet and dry season sampling episodes, and serve primarily to characterize the physico-chemical features of these sites. 
Prior to statistical analysis, periphyton mat TP (TP $\mu \mathrm{g} \mathrm{P} \mathrm{g}^{-1}$ dry mass) data were $\log 10$ transformed and diatom percentage abundance data were fourth root transformed to satisfy assumptions of normality (Clarke and Gorley, 2001). Rare species are often excluded from assemblage analyses because their presence can create a greater amount of "noise" in the data and often reduces the clarity of underlying patterns (McCune and Grace, 2002). Species that occurred in less than $1 \%$ of samples and at abundances of less than $5 \%$ were therefore considered rare and removed from the dataset prior to analyses.

Sampling effort was not the same at all locations, however, provided that samples are collected in a similar manner, from similar habitats and overlap with respect to species composition, the bias of unequal sampling effort can be circumvented by employing rarefaction curves (Tipper, 1979). A rarefaction curve represents an accumulation curve derived from averaging the species richness values observed in a number of randomly selected smaller sub-samples of a fixed size (n), pulled from the larger sample (N) (Siegel and German, 1982). These curves can then be compared among locations to determine whether or not differences in species-area distributions are evident. The shape of each curve reveals information regarding how well the assemblage was sampled relative to its overall richness. Curve shape is generally influenced by both the total number of species present within the sampled assemblage and the evenness of their distribution across sample sites (Hughes et al., 2001). Situations in which few species are present and/or species are distributed evenly across sample sites, result in curves which tend more towards a convex shape (i.e., steep initial incline, which begins to level off quickly). When species richness is relatively high and/or species are less evenly distributed across the sampled landscape, the likelihood of finding new species with each 
successive sampling event is increased, and this is reflected in the shape of the curve which tends towards a linear form (Hughes et al., 2001). The same shape may also occur as a result of small sample size.

Rarefaction curves were generated for each of the four locations and for the combined Caribbean sites using the program EstimateS, Version 8.2.0 ${ }^{\circledR}$ (Colwell, 2010; see http://viceroy.eeb.uconn.edu/estimates). Both the number of sampling sites and the number of species observed were relativized to their respective totals in order to compare the relationship between sampling effort and number of species observed (i.e., the shape of the curves) across all locations (Hughes et al., 2001).

Average per-site species richness and Shannon-Weiner diversity were also calculated for each location, and differences within and among locations were tested for using ANOVA, followed by Tukey's test, using the SPSS ${ }^{\circledR}$ statistical package. Relationships between richness, diversity and periphyton mat TP at each location were then examined using Pearson's correlation.

Diatom assemblage analyses were conducted using six sets of data: Everglades samples (E), Belize samples (B), Mexico samples (M), Jamaica samples (J), a composite of all the Belize, Mexico and Jamaica sites, collectively referred to as the Caribbean samples (C) and a composite of all sites from all locations (T). An initial analysis was done on the T dataset using Non-metric Multidimensional Scaling (NMDS) (done using the program PCORD $5{ }^{\circledR}$; McCune and Grace, 2002) and Analysis of Similarity (ANOSIM) (done using the program PRIMER ${ }^{\circledR}$ version 6; Clarke and Gorley, 2001) to examine differences among sites and locations, based on diatom assemblage. The stress value for the NMDS analysis was reported, along with the global $\mathrm{R}$ and significance 
values for the ANOSIM analysis. Subsequent ANOSIM pairwise comparative tests were used to evaluate significant differences in diatom assemblage between pairs of sites. The resultant $\mathrm{R}$ statistic and significance level were reported. The vector representing the direction and strength of the relationship between periphyton mat TP and diatom assemblage dissimilarity was applied to the NMDS plot and the $\mathrm{R}^{2}$ reported.

To determine whether or not the diatom assemblage at each site was influenced by sampling period, sites were categorized into wet and dry period samples and NMDS and ANOSIM analyses were then conducted on E, B, M, J and C datasets, using the categorized data to examine differences among the diatom assemblages of "wet" and “dry" TP sites at each location.

To evaluate the relationship between diatom assemblage and TP at each location, sites were first categorized as having either "high" or "low" TP periphyton mats. These designations were derived by first averaging the periphyton mat TP concentrations within a given location and then expressing the TP concentration for any given assemblage at a site within this location, as the deviation away from the local average, as shown below:

$$
\mathrm{C}=(\mathrm{OTP}-\mathrm{ATP}) / \mathrm{STP}
$$

Where $\mathrm{C}=$ the designated $\mathrm{TP}$ category, $\mathrm{OTP}=$ Observed periphyton mat $\mathrm{TP}$ concentration at the site, $\mathrm{ATP}=$ Average periphyton mat $\mathrm{TP}$ for the location and $\mathrm{STP}=$ Standard deviation of periphyton mat TP for location. This calculation produces the following categories:

$\mathrm{C}<0$ : Site mat TP concentration $<$ Average for location $\rightarrow$ Designated "Low" TP $\mathrm{C} \geq 0$ : Site mat TP concentration $\geq$ Average for location $\rightarrow$ Designated "High" TP 
The NMDS and ANOSIM analyses were then conducted on E, B, M, J and C datasets, using the categorized data, to examine differences among the diatom assemblages of "high" and "low" TP sites at each location. For each location, regression analysis and Pearson's correlation were used to test for significant linear relationships between the generated NMDS ordination scores and periphyton mat TP. Results are reported for all locations, however NMDS plots are shown for only the $\mathrm{E}$ and $\mathrm{C}$ datasets. The vector representing the direction and strength of the relationship between periphyton mat TP and diatom assemblage dissimilarity was again applied to each NMDS plot.

The program C2 (Juggins, 2003) was used to determine TP optima and tolerance levels for diatom species and subsequently create weighted averaging models based on the relative abundances of the various diatom species at different periphyton mat TP concentrations. This analysis was initially done for each of the four locations (E, B, M, J), however, the fewer the number of sites included in the analyses, the shorter the length of the TP gradient over which averages can be calculated for each species, and the greater the variation around the calculated average. Relatively small datasets therefore tend to produce less reliable models with elevated prediction errors. For this reason, the Belize, Mexico and Jamaica datasets, which contained 21, 10 and 10 sites respectively, were combined to form a single Caribbean dataset of 41 sites that was analyzed. Only the results for the Everglades and combined Caribbean sites are reported.

For the Everglades and combined Caribbean sites, observed periphyton mat TP was regressed against diatom inferred periphyton mat $T P$, and the predictive power $\left(\mathrm{R}^{2}\right)$ and the bootstrapped root mean square error of prediction (RSME expressed as $\mu \mathrm{g} \mathrm{P} \mathrm{g}{ }^{-1}$ periphyton mat dry weight) were calculated. Species common to all four locations were 
identified, and the TP optima calculated for combined Caribbean sites were regressed against the optima values for the same species at the Everglades sites.

Indicator species analysis (done using PCORD) was conducted to identify species that effectively indicated either "high" or "low" TP concentrations. This analysis again requires a minimum of data points to produce effective estimates and for this reason these analyses were only conducted with the Everglades dataset and the combined Caribbean dataset.

\section{RESULTS}

Habitat characteristics among the sampled locations overlapped, with most sites being dominated by Eleocharis spp. growing in shallow $(<1 \mathrm{~m})$ marl based soils, inundated by circumneutral waters. Among all four locations, average $\mathrm{pH}$ ranged from 7.2 to 9.2 and average conductivity ranged from 441.8 to $15,047.7 \mu \mathrm{S} \mathrm{cm}^{-1}$ (Table 4-2). Some sites within two areas at the Mexico location (Mahahual and Marisma) were closer to the coast and supported a macrophytic assemblage dominated by Rhizophora mangle and Eleocharis spp. At these sites average $\mathrm{pH}$ and conductivity levels were greater than all other sites (Table 4-2), which is a result of the influx of brackish-water at these sites.

A total of 187 diatom species representing 45 genera were recorded from the four locations (Table 4-3). Ninety-four of these species were included in diatom assemblage analyses following the removal of rare species. Of these 94 species, 22 were found to be present at all four locations and the most common among these (with average abundances greater than 1\% at all locations) were Brachysira neoexilis, Encyonema evergladianum, 
Encyonema spp., Fragilaria syngrotesca, Mastogloia smithii var. lacustris, Mastogloia smithii, Navicula cryptotenella, Nitzschia palaea and Nitzschia serpentiraphe.

Five rarefaction curves were generated, one for each of the four locations, and an additional curve based on the combined data from the three Caribbean locations (Figure 4-3). The shape of the Everglades curve shows that a large proportion of the species present was captured in a relatively small proportion of the samples collected. This suggests that the assemblage was adequately sampled. The curves generated for the Belize, Mexico, Jamaica and combined Caribbean sites all have practically the same shape, which implies that these assemblages were all sampled with equal effort relative to their overall richness. The actual shape of each of these curves, which tended toward a linear form, suggests that these locations had greater rates of species accumulation, greater diversity and required a greater sampling effort to capture the complement of species present.

Average, per-sample species richness at Everglades sites (14.9) was significantly lower $(\mathrm{p}<0.001)$ than Belize, Mexico and Jamaica sites $(18.5,18.7,21.9$ respectively) and the average per-sample species diversity for Everglades and Belize sites (1.59 and 1.66 respectively) were both significantly lower $(\mathrm{p}<0.001)$ than Mexico and Jamaica sites (2.00 and 2.01 respectively) (Table 4-4). Species diversity (H) did not show a significant relationship with TP at any of the locations. However, species richness was correlated with TP at the Belize sites $\left(\mathrm{R}^{2}=0.36, \mathrm{p}<0.01\right)$.

The NMDS analysis of the diatom assemblages from the four locations showed compositional overlap. There was however some separation of sites, with the Belize dry period assemblages being most distinct (Stress =0.17; Figure 4-4). The ANOSIM 
analysis confirmed the general NMDS pattern, revealing significant differences in diatom assemblages among Everglades and Caribbean sites (global $\mathrm{R}=0.417 ; \mathrm{p}<0.001$ ). Subsequent pairwise-comparison tests detected significant differences between all pairs of assemblages (All pairwise values for Global $\mathrm{R}>0.36$; $\mathrm{p}<0.02$ ), except for those from Jamaica wet and Mexico dry (Global $\mathrm{R}<0.27 ; \mathrm{p}>0.09$ ). The assemblages from the Belize dry period samples were the most different compared to all other assemblages (All pairwise values for Global $\mathrm{R}>0.63 ; \mathrm{p}<0.003)$. Compositional dissimilarity among diatom assemblages was correlated with periphyton mat $\mathrm{TP}\left(\right.$ Vector $\left.\mathrm{R}^{2}=0.41\right)$ and the Belize dry period assemblages clustered out at the high end of the TP range (Figure 4-4).

The NMDS and ANOSIM analyses conducted on assemblages categorized according to sample period showed an overlapping of "wet" and "dry" period assemblages, with no distinct separation between the groups, except for the clustering out of the Belize dry period sites (ANOSIM Global $\mathrm{R}=0.018$ and $\mathrm{p}=0.011$ ).

The NMDS analyses of assemblage data categorized according to periphyton mat TP concentrations (i.e., "high" or "low" TP assemblages), showed a separation of high and low TP assemblages within Belize (NMDS stress $=0.14$; ANOSIM Global $\mathrm{R}=0.431$ and $\mathrm{p}<0.001$ ), Mexico (NMDS stress $=0.05$; ANOSIM Global $\mathrm{R}=0.516$ and $\mathrm{p}<$ 0.017), Jamaica (NMDS stress $=0.11$; ANOSIM Global $\mathrm{R}=0.321$ and $\mathrm{p}<0.033$ ), Everglades $($ Stress $=0.19 ;$ ANOSIM Global $\mathrm{R}=0.228$ and $\mathrm{p}<0.001)($ Figure 4-5a), and combined Caribbean sites (Stress $=0.12$; ANOSIM Global $\mathrm{R}=0.197$ and $\mathrm{p}<0.001$ ) (Figure 4-5b). In each of the NMDS plots, diatom assemblage dissimilarity was correlated with periphyton mat TP (Belize: Vector $\mathrm{R}^{2}=0.44$; Mexico: Vector $\mathrm{R}^{2}=0.46$; 
Everglades: Vector $\mathrm{R}^{2}=0.436$; Caribbean: Vector $\mathrm{R}^{2}=0.564 ; \mathrm{p}<0.05$ ), except for the Jamaica plot $\left(\right.$ Vector $\left.\mathrm{R}^{2}=0.17 ; \mathrm{p}=0.24\right)$.

Two weighted averaging models were developed on the basis of the relative abundances of the various diatom species at different periphyton mat TP concentrations in the Everglades and for the combined Caribbean sites. Observed periphyton mat TP was regressed against diatom species inferred periphyton mat TP for the Caribbean and Everglades assemblages, respectively (Figure 4-6), and for both models, diatom inferred periphyton mat TP effectively predicted observed periphyton mat TP $\left(\right.$ Caribbean: $\mathrm{R}^{2}=$ 0.85, RMSE $=66.1 \mu \mathrm{g} \mathrm{TP} \mathrm{g}^{-1}$; Everglades: $\mathrm{R}^{2}=0.56, \mathrm{RMSE}=113.4 \mu \mathrm{g} \mathrm{TP} \mathrm{g}^{-1}$ )

The TP optima and tolerance levels for all species are presented in Table 4-2. An examination of the 22 species common to all four locations showed that the TP optimum for each of these species was generally lower at the Everglades sites than at the combined Caribbean sites $(\mathrm{p}<0.0001)$. Further examination revealed a positive relationship between the Everglades species optima and the Caribbean species optima $\left(R^{2}=0.53, p<\right.$ 0.001; Figure 4-7a). When the same 22 species were ranked according to their TP optima at Everglades and Caribbean sites respectively, there was also a positive relationship between the two sets of ranks $\left(R^{2}=0.50, p<0.001\right.$; Figure $\left.4-7 b\right)$.

Indicator species analysis identified 17 Everglades species and 11 Caribbean species that indicated either "high" or "low" periphyton mat TP concentrations (Table 4-2). Only one indicator species (Eunotia flexuosa) was shared by both Everglades and Caribbean sites, and this species indicated "high" TP concentrations at both locations. 


\section{DISCUSSION}

This study identified a core diatom assemblage of relatively common species that occurred across all Caribbean locations, which comprised a group of taxa previously documented as common in Everglades marshes. This assemblage, which includes Brachysira neoexilis, Encyonema evergladianum, Encyonema spp., Fragilaria syngrotesca, Mastogloia smithii var. lacustris, Mastogloia smithii, Navicula cryptotenella, Nitzschia palaea and Nitzschia serpentiraphe, is distinctive of, and possibly endemic to, subtropical and tropical freshwater karstic wetlands (Slate and Stevenson, 2000 and 2007; Gaiser et al 2006).

Some of these species have been previously recorded in freshwater habitats in Cuba (Foged, 1984) and Jamaica (Podzorski, 1985), and a survey of diatom assemblages from periphyton mats in the El Eden Ecological Reserve in Quintana Roo, Mexico, (Novelo et al., 2007; Ibarra et al., 2009). The current study is, however, the first to describe this distinctive core assemblage from periphyton mats in Belize and Jamaica.

Despite the ubiquitous presence of this core assemblage among the locations, there were some compositional differences among the four locations and among sites within each location. This variation is often seen as a result of natural habitat heterogeneity and microhabitat variability (Weilhoefer and Pan, 2006), but may also be due, in part, to the influence of environmental variables other than TP that were not evaluated in this particular study. The greatest disparity in assemblages among the locations involved the separation of the Belize dry period samples from all other 
assemblages. These samples were collected during an intense drought period from Eleocharis spp. marshes located adjacent to a river lagoon and are likely influenced by periodic, inland excursions of lagoon water. Periphyton samples at these sites were noncalcitic, unconsolidated and had elevated phosphorus levels, which is symptomatic of the form of periphyton present under conditions of deep water, with elevated phosphorus concentrations (McCormick and O’Dell, 1996). As such mat types were rare at other sites in this study, these samples were recognized as different in the community analyses.

Differences in sampling effort among locations could influence derived diversity and richness estimates owing to the possibility of an underestimation of diversity at under-sampled sites (Hughes et al., 2001). However, differences in the shapes of the Everglades, Belize, Mexico, Jamaica and combined Caribbean rarefaction curves showed that even though fewer sites were sampled at each of the Caribbean locations, periphyton mats from those locations supported a greater number of diatom species than those from the Everglades. This result, which was reinforced by the examination of average per-site richness and diversity, suggests that the Everglades diatom flora has a lower diversity than the compared Caribbean karstic wetland flora, however, the underlying reason for this is unclear.

The level of species diversity within a given locale is determined by a combination of factors. These include, but are not limited to: the distance between the locale and possible species source locations, the availability and efficiency of transport mechanisms, the frequency of immigration and emigration events, competitive interactions, habitat heterogeneity, evolutionary processes of speciation, stochastic disturbances and the length of time over which these factors are allowed to exert their 
various influences (Rosenzweig, 1997; Kristiansen, 1996; Hubbell, 2001; Charalambidou and Santamaria, 2002; Figuerola and Green 2002). The geographically isolated position of the Everglades and its relatively young geological age (ca. 5,000 years old) support the assumption that diatom assemblages may have developed following a process of species introductions from older regional wetlands (Slate and Stevenson, 2007). This would explain why the locations all share a core diatom assemblage, which under this scenario would have first developed in the older wetlands and subsequently been introduced to the Everglades following a series of dispersal events. This could also help to explain the lower diversity exhibited by the Everglades sites compared to the Caribbean sites. First, the Everglades system would be dependent on continuous introductions from the older systems to enhance the number of species present and it is reasonable to assume that the younger system (sink) would consistently have lower numbers of species than the older systems (source pools) until an equilibrium level is attained (Ricklefs, 1979). Second, in addition to species numbers increasing due to introductions, species numbers may also increase as a result of local speciation events. Again, it is expected that older systems would have a longer period over which such events could occur, compared to younger systems (Ricklefs, 1979). Both of these ideas suggest that the younger Everglades would have had less time to develop a more diverse flora than the older Caribbean sites.

The latitudinal diversity gradient, which is evidenced by the reduction in species richness with distance from the tropics, has been best documented in plant and animal communities from terrestrial and marine systems (Willig et al., 2003). The pattern of change in diversity has not been sufficiently examined as a forcing factor in freshwater, microbial communities (Leighton, 2005; Hillebrand, 2004), but could potentially 
influence diatom diversity patterns, such that subtropical systems such as the Everglades would have lower diversity than the more tropical Caribbean locations. It is also possible that the diversity of diatom species in the Everglades is restricted by particular features of the subtropical climate that are not experienced in the more tropical Caribbean locations. Foremost among these climatic features is temperature, which exhibits greater extremes in the sub-tropical Everglades wetland than in the tropical Caribbean wetlands. Under these conditions, species diversity in the Everglades may be limited to those that can tolerate the fluctuations in temperatures, whereas the more moderate tropical climate would support a wider range of species.

The influence of season on diatom assemblages was examined to rule out the possibility of seasonal effects masking or enhancing the influence of TP on diatom assemblages. Seasonal variability in light and temperature in the subtropics and tropics are muted relative to temperate ecosystems, so the greatest seasonal change experienced by subtropical and tropical wetlands is through the hydrologic response to pronounced seasonal differences in precipitation (McCormick et al., 1998; Thomas et al., 2006; Gottlieb et al., 2006). Seasonal changes in periphyton mats have been noted to occur within the Everglades, particularly a shift from dominance by filamentous cyanobacteria during the wet season, to diatoms during the dry season (McCormick et al., 1998). Although water depth is known to affect the spatial distribution of diatoms (Gaiser et al., 2009), differences in diatom assemblages between wet and dry periods have not been reported, and no such differences were found in the current study. Similarly, while spatial variation in water depth and periphyton TP are usually correlated (Gaiser et al., 2010), an examination of seasonal patterns in periphyton mat TP showed no differences between 
periphyton mat TP during wet and dry periods, except for at the Belize sites where the lagoonal dry period samples exhibited elevated TP levels.

The relationship between diatom assemblages and TP availability demonstrated in experimental and observational studies in the Everglades (McCormick et al., Cooper et al., Gaiser et al., 2005) have led to the development of diatom-based prediction models (Gaiser et al., 2006) that are now employed in system-wide habitat assessment (Gaiser et al., 2009). While these models provide a more accurate and meaningful assessment of habitat state than previous work on the subject, their findings have highlighted yet another important consideration, i.e. the validity of cross-system applications of these models. In a study examining periphyton responses to eutrophication within the Everglades, Gaiser et al. (2006) found that "ambient" periphyton mat TP levels from unimpacted wetland areas varied from 97 to $430 \mu \mathrm{g}$ P g-1 dry mass. This variation in periphyton mat TP levels among sites produced associated variations in diatom assemblage response to TP, such that a unique calibration model had to be produced for each individual wetland basin and no one model could be used to reliably infer quantitative TP levels across all sites. This indicated that instead of responding to absolute periphyton mat TP levels, diatom species were instead responding to relative changes in periphyton mat TP at each site.

In the current study, periphyton mat TP level at any given site was expressed as its deviation away from the local average periphyton mat TP level, instead of as an absolute value. Using this method, a clear pattern emerged, in which distinct "high" TP (above average) and "low" TP (below average) diatom assemblages could be identified at all locations. This implies that for a diatom assemblage within any given location, there 
is a defined response to changes in TP, relative to the baseline TP level for that area, as opposed to a standard response to a general threshold TP value that applies across sites.

This pattern was also evident in the species optima and tolerances, which differed among locations, but when ranked, revealed a consistent pattern in which species "preferences" for low or high TP levels were similar among locations. Subsequent analyses also identified species that were indicative of either high or low TP levels, though only one of these species (Eunotia flexuosa, which indicated "high" mat TP concentrations) was shared by both Everglades and Caribbean locations. The Everglades indicator species identified in this study were the same as those identified by Gaiser $e t$ al., (2005), including Eunotia flexuosa, Navicula cryptotenella, Eunotia incisa, Rhopalodia gibba and Nitzschia amphibia as indicators of elevated periphyton mat TP levels and Mastogloia smithii as an indicator of low periphyton mat TP levels. Several other studies have identified Mastogloia smithii as an indicator of TP levels in the Everglades (McCormick et al., 1996; Cooper et al., 1999; Pan et al., 2000; Slate and Stevenson, 2007), and it has been proposed as potential keystone taxon in these mats (Gaiser et al., 2010).

At both Everglades and Caribbean locations there was a strong relationship between diatom-inferred and observed periphyton mat TP, confirming that diatom assemblages can be used to infer periphyton mat TP in these wetlands. While both models were strong, the model produced for the combined Caribbean locations was more robust with a higher $\mathrm{R}^{2}$ and lower RMSE than the model for the Everglades location. This is likely due to fact that a greater number of sites were sampled in the Everglades, which would have introduced greater variability in habitat and environmental factors that 
may influence diatom assemblages and reduce the strength of the phosphorus signal (Slate, 1998).

The results of this study are consistent with findings from other work examining relationships between diatom assemblages and water quality across spatial expanses, and support the growing concern regarding the cross-system application of diatom-based water-quality assessment tools (Potapova and Charles, 2007). Diatom species assemblages, as well as the specific responses of individual species to environmental factors, can vary considerably even within habitat and/or geographic boundaries (Pipp, 2002; Kelly et al., 1998; Charles et al., 2006; Gaiser et al., 2006) and this can reduce the predictive power of models developed outside the target system. In addition, discrepancies in diatom taxonomic identification often arise when work is conducted by multiple investigators and this can reduce comparability of data across systems. However, diatom based monitoring techniques remain a powerful tool for water quality assessment and the careful application of this technique for the purposes of wetland monitoring and management within karstic wetlands in the Caribbean region should be encouraged. The development of site-specific models relating diatom assemblages to water quality would provide the most reliable and accurate information for use in biomonitoring programs within these systems. However, in the absence of data to develop such models, the cross-system application of inference models developed for the well-studied Everglades system may suffice, but only as a means of determining relative, as opposed to absolute, water quality state. 


\section{CONCLUSIONS}

The findings of this study have shown that the karstic wetlands of the South Florida Everglades share a number of similar features with those of Belize, Mexico and Jamaica, including a distinctive diatom flora that is likely characteristic of these types of habitats within the northern Caribbean region. Diatom assemblages within these habitats change in relation to periphyton mat TP concentrations, such that "low" and "high" TP assemblages can be identified. Species TP optima and indicator species differed between Everglades and Caribbean locations, however high-quality weighted averaging models effectively predicted mat TP concentrations from diatom assemblages for both Everglades and Caribbean locations.

The use of diatoms in aquatic biomonitoring programs has been well established for lakes (e.g. Dixit and Smol, 1994), rivers (e.g., Charles, 1996; Stevenson and Pan, 1999) and to a lesser extent, wetlands (e.g., Pan and Stevenson, 1996). The development of various standardized diatom indices (e.g., Lowe, 1974; van Dam et al., 1994) and diatom-based inference models (e.g., Gaiser et al., 2006) has allowed a more quantitative approach to water quality assessment and encourages cross system comparisons.

Challenges arise, however, when intrinsic ecosystem variability reduces the predictive power of these indices and models, even when applied within and across similar systems (Gaiser et al., 2006; Weilhoefer and Pan, 2006; Charles et al., 2006).

This current study provides an example of the value of diatoms as bioindicators for inferring water quality in karstic wetlands, but emphasizes the need for caution when applying diatom inference models across systems. While this strategy may on occasion 
be the only recourse available, in the absence of a robust monitoring program even moderate sampling within a given system can provide valuable supplementary information regarding water quality.

\section{ACKNOWLEDGMENTS}

The author would like to thank the Sian Ka'an Biosphere Reserve in Quintana Roo, Mexico and Lamanai Outpost in Orange Walk, Belize for facilitating site access and supporting this research. I also thank Clifton Ruehl, Raul Urgelles and collaborators from Universidad Nacional Autónoma de México for their assistance with the collection of field data from Mexico and Belize. I am also indebted to Dr. Marina Potapova of the Diatom Herbarium at the Ruth Patrick Center in the Philadelphia Academy of Sciences, Pensylvania, U.S.A, for her assistance with diatom identifications. This research was funded by the National Science Foundation under Grant No. DBI-0620409 and DEB9910514, as well as a grant to J. La Hée from the Latin American Caribbean Center at Florida International University.

The Southeast Environmental Research Center (SERC) at FIU also provided funding for this research. This is publication number $\mathrm{xxx}$ from SERC and $\mathrm{xxx}$ from the Tropical Biology Program of the Department of Biological Sciences at FIU. 


\section{LITERATURE CITED}

Azan, S. and Webber, D. 2007. The characterization and classification of the Black River Upper Morass, Jamaica, using the three-parameter test of vegetation, soils and hydrology. Aquatic Conservation: Marine and Freshwater Ecosystems 17:5-23

Azim, M. E. and T. Asaeda. 2005. Periphyton structure, diversity and colonization. Pages. 15-33. in M. E. Azim, M. C. J. Verdegem, A. A. van Dam, M. C. M. Beveridge. (editors). Periphyton: ecology, exploitation and management. CABI Publishing, Oxfordshire, UK.

Battarbee, R. W. 1986. Diatom analysis, p. 527-570. In B. E. Berglund [ed.], Handbook of Holocene palaeoecology and palaeohydrology. Wiley.

Browder JA, PJ Gleason, DR Swift. 1994 Periphyton in the Everglades: spatial variation, environmental correlates, and ecological implications. In: Davis SM, Ogden JC (eds) Everglades: The Ecosystem and its Restoration. St. Lucie Press, Delray Beach, Florida, pp 379-418

Cairns CE, Villanueva-Gutiérrez R, Koptur S, Bray DB. 2005 Bee populations, forest disturbance, and africanization in Mexico. Biotropica 37:686-692

CERP (Comprehensive Everglades Restoration Plan) 2005. 2005 report to Congress. http://www.evergladesplan.org/pm/program_docs/cerp_report_congress_2005.cfm. Accessed February, 2010

Charalambidou, I, Santamaria, L. 2002. Waterbirds as endozoochorous dispersers of aquatic organisms: A review of experimental evidence. Acta Oecologica-International Journal Of Ecology 23 (3): 165-176.

Charles DF, FW Acker, DD Hart, CW Reimer \& PB Cotter. 2006. Large-scale regional variation in diatom-water chemistry relationships: Rivers of eastern USA. Hydrobiologia 561(1): 27-57. 
Charles, D.F. 1996. Use of algae for monitoring rivers in the United States: Some examples. p. 109-118 in Whitton, B.A., and Rott, E., eds., Use of Algae for Monitoring Rivers II: Innsbruck, Austria, Institut für Botanik, Universität Innsbruk.

Childers, D. L., Jones, R. D., Trexler, J. C., Buzzelli, C., Boyer, J., Edwards, A. L., Gaiser, E. E., Jayachandaran, K., Lee, D., Meeder, J. F., Pechmann, J., Richards J. H. and Scinto. L. J. 2001. Quantifying the effects of low level phosphorus enrichment on unimpacted Everglades wetlands with in situ flumes and phosphorus dosing. In Porter, J. and K. Porter (Eds). The Everglades, Florida Bay, and Coral Reefs of the Florida Keys. CRC Press, Boca Raton, FL, USA. pp. 127-152.

Clarke K.R. and Gorley R.N. 2006. PRIMER v6: User manual/tutorial, PRIMER-E, Plymouth UK, 192pp.

Colwell, R. K. 2009. EstimateS: Statistical estimation of species richness and shared species from samples. Version 8.2. User's Guide and application published at: http://purl.oclc.org/estimates Accessed February, 2010.

Cooper, S.R., Huvane, J., Vaithiyanathan, P., Richardson, C.J., 1999. Calibration of diatoms along a nutrient gradient in Florida Everglades Water Conservation Area-2A, USA. Journal of Paleolimnology 22, 413-437.

Cox, E.J. 1991. What is the basis for using diatoms as monitors of river quality? In: Whitton, B.A., Rott, E. \& Friedrich, G. (eds.), In: The use of algae for monitoring rivers. $33-40$.

Cronberg G. 1982. Plankton of the Negril and Black River Morasses, Jamaica. Report to the PCJ Kingston, Jamaica.

Davis M, Lalor GC, Rattray R (1998) Nutrient status of the Black River System, St. Elizabeth, Jamaica. Jamaican Journal of Science and Technology 9:45-62

DeBusk, W.F., Newman, S., Reddy, K.R. (2001) "Spatio-temporal patterns of soil phosphorus enrichment in Everglades WCA-2A" J. Environ. Qual. 30: 1438-1446 
Dixit, S. S., J. P. Smol, J. C. Kingston \& D. F. Charles, 1992a. Diatoms: powerful indicators of environmental change. Environ. Sci. Technol. 26: 23-33.

Dixit, A. S., S. S. Dixit, and J. P. Smol. 1992b. Long-term trends in lake water pH and metal concentrations inferred from diatoms and chrysophytes in three lakes near Sudbury, Ontario. Canadian Journal of Fisheries and Aquatic Sciences 49:17-24. CSA

Dixit, S. S. and J. P. Smol. 1994. Diatoms as indicators in the Environmental Monitoring and Assessment Program - Surface Waters (EMAP-SW). Environmental Monitoring and Assessment 31:275-306. CSA

Donar CM, Condon KW, Gantar M, Gaiser EE (2004) A new technique for examining the physical structure of Everglades floating periphyton mat. Nova Hedwigia 78:107-19

Enell M (1984) Water Chemistry of the Negril and Black River Morasses, Jamaica. Petroleum Corporation of Jamaica, Kingston, Jamiaca.

Ewe, S.M.L., Gaiser, E.E., Childers, D.L., Rivera-Monroy, V.H., Iwaniec, D., Fourquerean, J., Twilley, R.R., 2006. Spatial and temporal patterns of aboveground net primary productivity (ANPP) in the Florida Coastal Everglades LTER (2001-2004). Hydrobiologia 569, 459-474.

Figuerola J, Green A.J. Dispersal of aquatic organisms by waterbirds: a review of past research and priorities for future studies. Freshwater Biol. 2002;47:483-494.

Foged, N. 1984. Freshwater and littoral diatoms from Cuba. Bibliotheca Diatomologica, Kramer, Germany. 123 pp.

Fritz, S.C.; Cummings, B.C.; Gasse, F. and K.F. Laird. (1999), Diatoms as a indicator of hydrologic and climate change in saline lakes. In: Stoermer, E.F. and Smol, J.P. (eds). The Diatoms: applications for the environmental and earth sciences. Cambridge University Press. Cambridge, pp. 41-73.

Gaiser EE, Scinto LJ, Richards JH, Jayachandrana K, Childers DL, Trexler JC, Jones RD (2004) Phosphorus in periphyton mats provides the best metric for detecting low-level $\mathrm{P}$ enrichment in an oligotrophic wetland. Water Research 38:507-516 
Gaiser EE, Trexler JC, Richards JH, Childers DL, Lee D, Edwards AL, Scinto LJ, Jayachandran K, Noe GB, Jones RD (2005) Cascading ecological effects of low-level phosphorus enrichment in the Florida Everglades. Journal of Environmental Quality $34: 717-723$

Gaiser EE, Richards JH, Trexler JC, Jones RD, Childers DL (2006) Periphyton responses to eutrophication in the Florida Everglades: cross-system patterns of structural and compositional change. Limnology and Oceanograohy 51:617-630

Gaiser EE (2009) Periphyton as an indicator of restoration in the Florida Everglades. Ecological Indicators 9: S37-S45

Gaiser, E. E., La Hée, J. M., Tobias, F. A. C., Wachnicka, A. H. 2010. Mastogloia smithii var. lacustris Grun.: A structural engineer of calcareous mats in karstic subtropical wetlands. Proceedings of the Academy of Natural Sciences of Philadelphia (in press)

Gleason PJ, Spackman W (1974) Calcareous periphyton and water chemistry in the Everglades. In: Gleason PJ (ed.) Environments of South Florida: Past and Present, Memoir No. 2. Miami Geological Society, Coral Gables, Florida, pp 225-248

Goldsborough LG, Robinson GGC (1996) Pattern in wetlands. In: Stevenson RJ, Bothwell ML, Lowe RL (eds.) Algal Ecology in Freshwater Benthic Ecosystems. Academic Press, pp 77-117

Gottlieb AD, Richards JH, Gaiser EE (2006) Comparative study of periphyton community structure in long and short hydroperiod Everglades marshes. Hydrobiologia 569:195-207

Grimshaw HJ, Rosen M, Swift DR, Rodberg K, Noel JM (1993) Marsh phosphorus concentrations, phosphorus content and species composition of Everglades periphyton communities. Archiv für Hydrobiologie 128:257-276

Gunderson LH (1994) Vegetation of the Everglades: Determinants of community composition. In: Davis SM, Ogden JC (eds) Everglades: The Ecosystem and its Restoration. St. Lucie Press, Delray Beach, Florida, pp 323-340 
Hubbell, S.P. 2001. A Unified Neutral Theory of Biodiversity and Biogeography, Princeton University Press, Princeton.

Hughes, J. B., Hellman, J. J., Ricketts, T. H. and Bohannan, B. J. M. 2001. Counting the uncountable: Statistical approaches to estimating microbial diversity. Applied and Environmental Microbiology. 67(10): 4399 - 4406.

Ibarra C., Tavera, R. and Novelo, E. 2009. Diversity and structure of periphyton and metaphyton diatom communities in a tropical wetland in Mexico. Revista Mexicana de Biodiversidad 80: 763- 769.

Inglett, P.W., D'Angelo, E.M., Reddy, K.R., McCormick, P.V. and Hagerthey, S.E. 2009. Periphyton nitrogenase activity as an indicator of wetland eutrophication: spatial patterns and response to phosphorus dosing in a northern Everglades ecosystem. Wetlands Ecology and Management 17(2), 131-144.

Iwaniec DM, Childers DL, Rondeau D, Madden CJ, Saunders CJ (2006) Effects of hydrologic and water quality drivers on periphyton dynamics in the southern Everglades. Hydrobiologia 569:223-235

Juggins. S. 2003. C2 User guide. Software for ecological and palaeoecological data analysis and visualisation. University of Newcastle, Newcastle upon Tyne, UK. 69pp.

Kelly, M.G., Cazaubon, A., Coring, E., Dell'Uomo, A., Ector, L., Goldsmith, B., Guasch, H., Hürlimann, J., Jarlman, A., Kawecka, B., Kwadrans, J., Laugaste, R., Lindstrøm, E.A., Leitao, M., Marvan, P., Padisa'k, J., Pipp, E., Prygiel, J., Rott, E., Sabater, S., van Dam, H., Vizinet, J., 1998. Recommendations for the routine sampling of diatoms for water quality assessments in Europe. J. Appl. Phycol. 10, 215-224.

Kristiansen J. 1996. Dispersal of freshwater algae - A review. Hydrobiologia 336 (1-3): $151-157$

Kushlan, J. A. 1981. Sampling characteristics of enclosure fish traps. Transactions of the American Fisheries Society 110: 557-662. 
La Hée, J. M., Gaiser, E. E., Trexler, J. C. and Loftus, W. F. In preparation. Phosphorus and hydrology as drivers of periphyton biomass in the Everglades and three tropical karstic wetlands.

Liston SE, Newman S, Trexler JC (2008) Macroinvertebrate community response to eutrophication in an oligotrophic wetland: An in situ mesocosm experiment. Wetlands 28:686-694

Lowe, R.L., and Pan, Y., 1996. Benthic algal communities as biological monitors, p. 705739 in Stevenson, R.J., M. Bothwell, and R.L.Lowe, eds., Algal ecology: freshwater benthic ecosystems: San Diego, Academic Press.

Lowe, R.L., 1974. Environmental Requirements and Pollution Tolerance of Freshwater Diatoms. National Environmental Research Center, Office of Research and Development, U.S. Environmental Protection Agency, Cincinnati, OH.

Massa AK, Haynes-Sutton A (1998) Environmental Policy Framework, Parish of St. Elizabeth, Jamaica. Technical Support Services Inc. Prepared for the Natural Resources Conservation Authority Protected Areas Management Branch and the United States Agency for International Development.

McCormick PV, O’Dell MB (1996) Quantifying periphyton responses to phosphorus in the Florida Everglades: a synoptic-experimental approach Journal of the North American Benthological Society 15:450-468

McCormick PV, Rawlik PS, Lurding K, Smith EP, Sklar FH (1996) Periphyton-water quality relationships along a nutrient gradient in the northern Everglades. Journal of the North American Benthological Society 15: 433-449

McCormick PV, Stevenson RJ (1998) Periphyton as a tool for ecological assessment and management in the Florida Everglades. Journal of Phycology 34:726-733

McCormick PV, Shuford III RBE, Backus JB, Kennedy WC (1998) Spatial and seasonal patterns of periphyton biomass and productivity in the northern Everglades, FL, USA. Hydrobiologia 362:185-208 
McCormick, P.V. and Scinto, L.J., 1999. Influence of phosphorus loading on wetlands periphyton assemblages: A case study from the Everglades. In: Reddy, K.R., Editor, 1999. Phosphorus Biogeochemistry in Subtropical Ecosystems, CRC Press, Boca Raton, FL, pp. 301-319.

McCormick, P. V., M. B. O'Dell, R. B E. Shuford III, J. G. Backus, and W. C. Kennedy. 2001. Periphyton responses to experimental phosphorus enrichment in a subtropical wetland. Aquatic Botany 71:119-139.

McCune B, Grace JB (2002) Analysis of Ecological Communities, MJM Press, Gleneden Beach, Oregon, USA

Meerman JC (2006) Ecological Characterization of the New River Lagoon, Orange Walk District, Belize. Report prepared for the Freshwater Programme for Belize, Belize City

Munyon, J.W., J.S. Schedlbauer, S.F. Oberbauer, E.E. Gaiser, and G. Starr. In preparation. Contrasting ecosystem productivity between a long- and short-hydroperiod marsh in the Florida Everglades.

Noe, G. B., Childers, D. L. and Jones, R. D. 2001. Phosphorus biogeochemistry and the impact of phosphorus enrichment: Why is the Everglades so unique? Ecosystems 4: 603624.

Noe GB, Childers DL, Edwards AL, Gaiser E, Jayachandaran K, Lee D, Meeder J, Richards J, Scinto LJ, Trexler J, Jones RD. 2002. Short-term changes in phosphorus storage in an oligotrophic Everglades wetland ecosystem receiving experimental nutrient enrichment. Biogeochemistry 59:239-67

Noe GB, Childers DL (2007) Phosphorus budgets in Everglades wetland ecosystems: the effects of hydrology and nutrient enrichment. Wetlands Ecology Management 15:189205

Novelo E, Tavera R, Ibarra C (2007) Bacillariophyceae from Karstic Wetlands in Mexico. Bibliotheca Diatomologica 54:1-136 
Novelo E, Tavera R (2003) The role of periphyton in the regulation and supply of nutrients in a wetland at El Edén, Quintana Roo. In: Gómez-Pompa A, Allen MF, Fedick SL, Jiménez-Osornio JJ (eds.) The Lowland Maya Area. Three Millennia and the Human-Wildland Interface. Food Products Press, NY, pp 217-239

Pan, Y. and R. J. Stevenson, 1996. Gradient analysis of diatom assemblage in western Kentucky wetlands. Journal of Phycology. 32: 222-232.

Pan, Y., Stevenson, R.J., Vaithiyanathan, P., Slate, J., Richardson, C.J., 2000. Changes in algal assemblages along observed and experimental phosphorus gradients in a subtropical wetland, USA. Freshwater Biol. 44, 339-353.

Podzorski A.C. 1985. An Illustrated and Annotated Check-List of Diatoms from the Black River Waterways, St. Elizabeth, Jamaica. Bibliotheca Diatomologica. 7:1-177

Pipp, E., 2002. A regional diatom-based trophic state indication system for running water sites in Upper Austria and its over-regional applicability. Verh. Int. Verein. Limnol. 27, 3376-3380.

Potapova, M. \& D. F. Charles. 2007. Diatom metrics for monitoring eutrophication in rivers of the United States. Ecological Indicators 7(1): 48-70.

Raschke, R.L., 1993. Diatom (Bacillariophyta) community response to phosphorus in the Everglades National Park, USA. Phycologia 32, 48-58.

Reddy, K.R., R.D. DeLaune, W.F. DeBusk, and M.A. Koch. 1993. Long term nutrient accumulation rates in the Everglades. Soil Sci. Soc. Am. J. 57:1147-1155

Rejmánková E, Pope KO, Post R, Maltby E (1996) Herbaceous wetlands of the Yucatan peninsula: communities at extreme ends of environmental gradients. Internationale Revue der Gesamten Hydrobiologie 81:223-252

Rejmánková E and Komárková J (2000) Function of cyanobacterial mats in phosphoruslimited tropical wetlands. Hydrobiologia 431:135-153 
Rejmánková E (2001) Effect of experimental phosphorus enrichment on oligotrophic tropical marshes in Belize, Central America. Plant Soil 236:33-53

Rejmánková, E. and J. Komárková. 2005. Response of cyanobacterial mats to nutrient and salinity changes. Aquatic Botany 83:87-107.

Richardson CJ (2009) The Everglades: North America's subtropical wetland. Wetlands Ecology and Management, DOI: 10.1007/s11273-009-9156-4.

Ricklefs, R. E. 1979. Ecology (second edition). Chiron Press, New York, xii + 966 pp.

Rosenzweig, 1997 Species diversity in space and time. (Revised ed.) Cambridge University Press, Cambridge, UK., 436 pp.

Round FE (1991) Use of diatoms for monitoring rivers. In Whitton BA, Rott E, Friedrich G (eds), Use of Algae for Monitoring Rivers. Universität Innsbruck, Innsbruck, 25-32.

Round FE (1993) A review and methods for the use of epilithic diatoms for detecting and monitoring changes in river water quality 1993.65 pp. Methods for the Examination of Waters and Associated Materials. Her Majesty's Stationary Office, London.

Scinto, L.J. and K.R. Reddy. 2003. Biotic and abiotic uptake of phosphorus by periphyton in a subtropical freshwater wetland. Aquatic Botany 77: 203-222. Siegel and German, 1982

Siegel A.F. and German R.Z. (1982) Rarefaction and taxonomic diversity. Biometrics 38, $235-41$.

Slate, J.E., and R.J. Stevenson. 2000. Recent and abrupt environmental change in the Florida Everglades indicated from siliceous microfossils. Wetlands 20:346-356.

Slate, J. E. and R. J. Stevenson. 2007. The diatom flora of phosphorus-enriched and unenriched sites in an Everglades marsh. Diatom Research 22: 355-386. 
Slate, J. E. 1998. Inference of present and historical environmental conditions in the Everglades with diatoms and other siliceous microfossils. Ph.D. Dissertation. University of Louisville, Louisville, KY, USA.

Smith, S. M., Leeds, J. A., McCormick, P. V., Garrett P. B., Darwish, M. 2009. Sawgrass (Cladium jamaicense) responses as early indicators of low-level phosphorus enrichment in the Florida Everglades. Wetlands Ecology and Management. 17:291-302. Smol, J. P., Battarbee, R. W., Davis, R. B. and Meriläinen J. (Eds.) 1986. Diatoms and Lake Acidity. Reconstructing $\mathrm{pH}$ from siliceous algal remains in lake sediments. Developments in Hydrobiology 29. Series ed.: H. J. DUMONT. 307 pp. Dordrecht/Boston/Lancaster: Dr. W. Junk Publishers.

Solórzano JH, Sharp L (1980) Determination of total dissolved phosphorous and particulate phosphorous in natural waters, Limnology and Oceanography 25:754-758

Stal LJ (2000) Cyanobacterial mats and stromatolites. In: Whitton BA, Potts M (eds) The Ecology of Cyanobacteria: Their Diversity in Time and Space. Kluwer Academic Publishers, Dordrecht, The Netherlands, pp 61-120

Stevenson, R. J. and Y. Pan. 1999. Assessing ecological conditions in rivers and streams with diatoms. In: E. F. Stoermer and J. P. Smol, eds. The Diatoms: Applications to the Enviro-nmental and Earth Sciences. Pp. 11-40. Cambridge University Press, Cambridge, UK.

Swift DR, Nicholas RB (1987) Periphyton and water quality relationships in the Everglades Water Conservation Areas, 1978-1982. Technical Publication 872, South Florida Water Management District, West Palm Beach, Florida

Thomas S, Gaiser EE, Gantar M, Scinto L, Jones RD (2006) Quantifying the response of calcareous periphyton crusts to rehydration: a microcosm study (Florida Everglades). Aquatic Botany 84:317-323

Tipper, J. C. 1979. Rarefaction and rarefiction - The use and abuse of a method in paleoecology. Paleobiology. 5(4): $423-434$. 
Van Dam, H., A. Mertens, and J. Sinkledam. 1994. A coded checklist and ecological indicator values of freshwater diatoms from the Netherlands. Netherlands Journal of Aquatic Ecology. 28(1): 117-133.

Van Meter-Kasanof N (1973) Ecology of the microalgae of the Florida Everglades. Part I. Environment and some aspects of freshwater periphyton, 1959 to 1963 . Nova Hedwigia 24:619-664

Weidie AE (1985) Geology of the Yucatan platform. In: Ward WC, Weidie AE, Back W (eds) Geology and hydrology of the Yucatan and Quaternary geology of northeastern Yucatan peninsula New Orleans Geological Society, pp 1-19

Weilhoefer, C.L. and Y. Pan. 2006. Diatom-based bioassessment in wetlands: how many samples do we need to adequately characterize the diatom assemblage in a wetland? Wetlands 26:793-802

Williams AJ, Trexler JC (2006) A preliminary analysis of the correlation of food-web characteristics with hydrology and nutrient gradients in the southern Everglades. Hydrobiologia 569:493-504 
Table 4-1. Location of Caribbean sampling sites, presented as latitudinal and longitudinal bounding GPS coordinates of sampling sites within each location.

\begin{tabular}{lccc}
\hline & $\begin{array}{c}\text { Sian Ka'an National Park, } \\
\text { Quintana Roo, Mexico }\end{array}$ & $\begin{array}{c}\text { New River Lagoon, Indian } \\
\text { Church, Belize }\end{array}$ & $\begin{array}{c}\text { Slipe River, Black River Morass, } \\
\text { St. Elizabeth, Jamaica }\end{array}$ \\
\hline EAST & $087^{\circ} 30.585$ & $88^{\circ} 37.958^{\prime}$ & $78^{\circ} 46.972$ \\
WEST & $087^{\circ} 57.579$ & $88^{\circ} 39.212^{\prime}$ & $77^{\circ} 48.874$ \\
NORTH & $19^{\circ} 52.342$ & $17^{\circ} 47.111^{\prime}$ & $18^{\circ} 03.182$ \\
SOUTH & $18^{\circ} 47.223$ & $17^{\circ} 37.166$ & $18^{\circ} 01.524$ \\
\hline
\end{tabular}

Table 4-2. Number of sites sampled (N), water characteristics and periphyton attributes for each location during wet and dry periods. Average values are given along with standard deviation values in brackets. Missing data are indicated with a dash (-).

\begin{tabular}{|c|c|c|c|c|c|c|c|c|c|c|c|c|}
\hline SITE & $\mathrm{N}$ & $\mathrm{pH}$ & $\begin{array}{l}\text { Conductivity } \\
\qquad\left(\mu \mathrm{S} \mathrm{cm}^{-1}\right)\end{array}$ & $\begin{array}{l}\text { Water } \\
\text { depth } \\
(\mathrm{cm})\end{array}$ & $\begin{array}{c}\text { Total } \\
\text { Biovolume } \\
\left(\mathrm{ml} \mathrm{m}^{-2}\right)\end{array}$ & $\begin{array}{l}\text { Biovolume } \\
\left(\mathrm{ml} \mathrm{m}^{-2}\right)\end{array}$ & $\begin{array}{c}\text { TP } \\
(\mu \mathrm{g} \mathrm{P} \\
\mathrm{g}^{-1} \\
\mathrm{DM})\end{array}$ & $\begin{array}{c}\text { Dry } \\
\text { Mass } \\
\left(\mathrm{g} \mathrm{m}^{-2}\right)\end{array}$ & $\begin{array}{c}\text { Organic } \\
\text { content } \\
(\%)\end{array}$ & $\begin{array}{l}\text { Ash } \\
\text { Free } \\
\text { Dry } \\
\text { Mass } \\
\left(\mathrm{g} \mathrm{m}^{-}\right. \\
2 \text { ) }\end{array}$ & $\begin{array}{l}\text { Chlorophyll } \\
\quad\left(\mu \mathrm{g} \mathrm{m}^{-2}\right)\end{array}$ & $\begin{array}{l}\text { Chlorophyll } \\
\text { concentration } \\
\left(\mu \mathrm{g} \mathrm{g}^{-1} \mathrm{DM}\right)\end{array}$ \\
\hline $\begin{array}{l}\text { Belize } \\
\text { Wet }\end{array}$ & 12 & $\begin{array}{c}7.3 \\
(0.5)\end{array}$ & $\begin{array}{c}441.8 \\
(208.6)\end{array}$ & $\begin{array}{l}73.2 \\
(8.5)\end{array}$ & $\begin{array}{c}876.0 \\
(1474.8)\end{array}$ & $\begin{array}{c}857.1 \\
(1486.4)\end{array}$ & $\begin{array}{c}239.7 \\
(106.7)\end{array}$ & $\begin{array}{c}77.1 \\
(133.4)\end{array}$ & $\begin{array}{c}67.8 \\
(19.1)\end{array}$ & $\begin{array}{c}30.1 \\
(48.2)\end{array}$ & $\begin{array}{c}140.2 \\
(132.7)\end{array}$ & $\begin{array}{c}48.3 \\
(52.5)\end{array}$ \\
\hline $\begin{array}{l}\text { Belize } \\
\text { Dry }\end{array}$ & 9 & $\begin{array}{c}8.3 \\
(0.2)\end{array}$ & $\begin{array}{c}690.3 \\
(104.0)\end{array}$ & $\begin{array}{c}31.6 \\
(11.8)\end{array}$ & $\begin{array}{c}101.6 \\
(264.6)\end{array}$ & $\begin{array}{c}101.6 \\
(264.6)\end{array}$ & $\begin{array}{c}543.1 \\
(187.9)\end{array}$ & $\begin{array}{c}3.2 \\
(6.7)\end{array}$ & $\begin{array}{c}37.4 \\
(17.9)\end{array}$ & $\begin{array}{c}1.5 \\
(3.0)\end{array}$ & $\begin{array}{c}1288.5 \\
(2602.0)\end{array}$ & $\begin{array}{c}260.6 \\
(175.0)\end{array}$ \\
\hline $\begin{array}{l}\text { Jamaica } \\
\text { Wet }\end{array}$ & 5 & $\begin{array}{c}7.9 \\
(0.2)\end{array}$ & $\begin{array}{l}522.6 \\
(62.4)\end{array}$ & $\begin{array}{c}9.6 \\
(3.6)\end{array}$ & - & - & $\begin{array}{c}405.2 \\
(158.3)\end{array}$ & - & - & - & - & - \\
\hline $\begin{array}{l}\text { Jamaica } \\
\text { Dry }\end{array}$ & 5 & $\begin{array}{c}8.4 \\
(0.5)\end{array}$ & $\begin{array}{c}447.6 \\
(137.3)\end{array}$ & $\begin{array}{c}11.6 \\
(12.7)\end{array}$ & $\begin{array}{c}2251.3 \\
(1712.6)\end{array}$ & $\begin{array}{c}2251.3 \\
(1712.6)\end{array}$ & $\begin{array}{l}200.3 \\
(16.5)\end{array}$ & $\begin{array}{c}156.0 \\
(104.8)\end{array}$ & $\begin{array}{l}28.7 \\
(7.2)\end{array}$ & $\begin{array}{c}39.4 \\
(25.5)\end{array}$ & $\begin{array}{c}29693.0 \\
(19940.6)\end{array}$ & $\begin{array}{l}222.5 \\
(83.1)\end{array}$ \\
\hline $\begin{array}{l}\text { Mexico } \\
\text { Wet }\end{array}$ & 6 & - & $\begin{array}{l}1259.0 \\
(952.5)\end{array}$ & $\begin{array}{c}37.9 \\
(10.3)\end{array}$ & $\begin{array}{c}7460.7 \\
(3043.8)\end{array}$ & $\begin{array}{c}6772.6 \\
(2957.6)\end{array}$ & $\begin{array}{l}212.5 \\
(93.7)\end{array}$ & $\begin{array}{c}365.0 \\
(195.5)\end{array}$ & $\begin{array}{l}37.9 \\
(7.4)\end{array}$ & $\begin{array}{l}121.4 \\
(49.5)\end{array}$ & $\begin{array}{c}37195.4 \\
(12261.7)\end{array}$ & $\begin{array}{l}129.7 \\
(51.5)\end{array}$ \\
\hline $\begin{array}{l}\text { Mexico } \\
\text { Dry }\end{array}$ & 4 & $\begin{array}{c}9.2 \\
(0.4)\end{array}$ & $\begin{array}{c}15047.7 \\
(16670.5)\end{array}$ & $\begin{array}{c}30.3 \\
(23.4)\end{array}$ & $\begin{array}{c}4564.3 \\
(2568.5)\end{array}$ & $\begin{array}{l}4144.6 \\
(2720)\end{array}$ & $\begin{array}{c}193.7 \\
(210.9)\end{array}$ & $\begin{array}{c}317.4 \\
(233.9)\end{array}$ & $\begin{array}{c}42.5 \\
(15.5)\end{array}$ & $\begin{array}{l}109.4 \\
(76.5)\end{array}$ & $\begin{array}{c}133456.4 \\
(153012.9)\end{array}$ & $\begin{array}{c}465.3 \\
(257.1)\end{array}$ \\
\hline
\end{tabular}


Table 4-3. List of non-rare species ( $>1 \%$ average abundance) showing the number of locations $(\mathrm{N})$ at which each species was found, along with its average percentage abundance at each location: Everglades (E), Belize (B), Mexico (M), Jamaica (J) and Caribbean locations combined (C). Species absence from a location is indicated with a dash (-). TP optimum and tolerance values (TP Opt (Tol)) are given for the 22 species that were present at all locations and indicator species (I) are identified as indicating high or low TP for the Everglades $\left({ }^{* *}=\right.$ high TP; ${ }^{*}=$ low TP) and Caribbean $\left({ }^{t}=\right.$ high TP; ${ }^{t}=$ low TP) locations.

\section{TAXON}

Achnanthidium neomicrocephalum H. Lange-Bertalot \& F. Staab

Brachysira neoexilis Lange-Bertalot

Cyclotella meneghiniana Kützing

Diploneis oblongella (Naegelii ex. Kutzing) Ross

Diploneis parma Cleve

Encyonema evergladianum Krammer

Encyonema sp. 5

Encyonema sp. 6

Encyonopsis microcephala (Grunow) Krammer in Krammer

Eunotia flexuosa (Brébisson) Kützing

Fragilaria nanana Lange-Bertalot

Fragilaria synegrotesca Lange-Bertalot

Fragilaria ulna var. ulna (Nitzsch) Lange-Bertalot

Gomphonema cf. vibriodes Reichardt \& Lange-Bertalot

Gomphonema intricatum var. vibrio (Ehrenberg) Cleve

Mastogloia cf. smithii Thwaites ex. W. Smith

Mastogloia smithii var. lacustris Grunow

Navicula cf. radiosa Kutzing

$\begin{array}{ccccccccc}4 & 1.4 & 27.0 & 0.7 & 1.2 & 191(24) & 442(33) & \text { \# } & \\ 4 & 7.8 & 25.3 & 5.9 & 7.6 & 147(23) & 273(32) & & \\ 4 & 0.4 & 0.4 & 1.2 & 0.4 & 163(27) & 289(29) & & \\ 4 & 0.6 & 0.2 & 0.9 & 1.9 & 128(19) & 225(27) & & \\ 4 & 0.7 & 0.2 & 0.3 & 1.5 & 137(24) & 235(30) & & \\ 4 & 23.2 & 16.3 & 20.3 & 29.6 & 146(22) & 229(28) & \text { t } & \\ 4 & 3.4 & 1.7 & 5.8 & 3.3 & 177(26) & 230(27) & & * * \\ 4 & 0.6 & 0.2 & 0.6 & 0.1 & 177(26) & 230(27) & & * * \\ 4 & 2.7 & 0.2 & 1.1 & 10.8 & 189(29) & 334(25) & & * * \\ 4 & 0.6 & 0.5 & 0.2 & 0.5 & 239(30) & 368(25) & \text { \# } & * * \\ 4 & 0.7 & 2.8 & 3.5 & 2.2 & 199(26) & 263(29) & & \\ 4 & 11.2 & 14.0 & 6.0 & 6.6 & 168(25) & 266(29) & & * * \\ 4 & 1.0 & 2.3 & 0.2 & 0.6 & 266(32) & 281(31) & & \\ 4 & 0.9 & 1.7 & 4.0 & 0.2 & 206(26) & 406(32) & \text { \# } & \\ 4 & 0.9 & 1.2 & 0.5 & 0.7 & 172(26) & 329(32) & & * * \\ 4 & 37.6 & 6.3 & 21.8 & 6.7 & 152(24) & 240(29) & & * \\ 4 & 2.5 & 1.8 & 1.6 & 0.4 & 128(20) & 239(26) & \\ 4 & 0.9 & 1.2 & 1.6 & 1.0 & 198(27) & 282(35) & & * *\end{array}$


Table 4-3. C'tnd.

\section{TAXON}

Navicula cryptotenella Lange-Bertalot Navicula subtilissima Cleve

Nitzschia palaea (Kutzing) W. Smith

Nitzschia serpentiraphe Lange-Bertalot

Sellaphora laevissima Krammer

Caponea caribbea Podzorski

Nitzschia lacunarum Hustedt in A. Schmidt et al.

Encyonema silesiacum (Bleisch) Mann

Eunotia camelus Ehrenberg

Navicella pusilla (Grunow) Krammer

Encyonopsis subminuta Krammer et Reichardt

Navicula heimansioides Lange-Bertalot

Nitzschia semirobusta Lange-Bertalot

Achnanthidium sp. 2

Cocconeis placentula Ehrenberg

Fragilaria capucina var. vaucheriae

Gomphonema gracile Ehrenberg

Nitzschia nana Grunow in Van Heurck

Pinnularia microstauron (Ehrenberg) Cleve

Sellaphora pupula (Kützing) Mereschkowsky

Gomphonema affine Kützing

Amphora sulcata (Brébisson) Cleve
Average $\%$ abundance

TP Opt (Tol)

I

E

B

M

$\mathrm{C}$$$
4 \quad 1.6 \quad 1.2
$$$$
4 \begin{array}{lll}
4 & 1.6 & 1.2
\end{array}
$$$$
4 \quad 4.0
$$$$
4 \quad 0.6 \quad 0 .
$$

3

3
3

0.7

$4 \quad 0$.

34 .

3
3
3
3
3

3

3

3

3

3
3
3

3
3
3

3

3


Table 4-3. C'ntd.

\section{TAXON}

Brachysira brebissonii Ross

Eunotia cf. monodon Ehrenberg

Eunotia rhabenhorstiana (Patrick) Metzeltin \& Lange-Bertalot

Frustulia rhomboides var. crassinervia (Brebisson ex. W. Smith)

Ross

Neidium ampliatum (Ehrenberg) Krammer

Nitzschia amphibia Grunow

Stenopterobia curvula (W. Smith) Krammer

Eunotia cf. karenae Metzeltin \& Lange-Bertalot

Gomphonema maclaughlinii Reichardt

Nitzschia denticula Grunow

Nitzschia microcephala Grunow

Pinnularia sp. 1

Plagiotropis sp. 1

Diploneis oblongella (Naegeli ex Kuetzing) Ross

Diploneis sp. 1

Nitzschia tubicola Grunow

Rhopalodia sp. 1

Achnanthidium exiguum (Grunow) Czarnecki

Achnanthidium sp. 1

Amphora ovalis (Kützing) Kützing

Caloneis sp. 2

Encyonopsis sp. 1

Eunotia sp. 2

\begin{tabular}{ccccc}
$\mathrm{N}$ & \multicolumn{5}{c}{ Average \% abundance } \\
& $\mathrm{E}$ & $\mathrm{B}$ & $\mathrm{M}$ & $\mathrm{J}$ \\
2 & 1.2 & 34.5 & - & - \\
2 & 0.3 & 1.6 & - & - \\
2 & 0.3 & 0.8 & - & - \\
2 & 0.6 & 0.3 & - & - \\
2 & 0.3 & 0.3 & - & - \\
2 & 0.7 & 14.9 & - & - \\
2 & 0.3 & 0.2 & - & - \\
2 & - & 1.8 & 0.4 & - \\
2 & - & 0.2 & 0.2 & - \\
2 & - & 13.4 & 5.4 & - \\
2 & - & 0.8 & 1.1 & - \\
2 & - & 0.3 & 0.3 & - \\
2 & - & 1.8 & 0.2 & - \\
2 & - & - & 0.2 & 0.6 \\
2 & - & - & 0.2 & 0.1 \\
2 & - & - & 14.1 & 2.8 \\
2 & - & - & 0.6 & 1.1 \\
2 & - & 2.8 & - & 0.4 \\
2 & - & 2.8 & - & 0.2 \\
2 & - & 0.3 & - & 0.3 \\
2 & - & 0.2 & - & 0.4 \\
2 & - & 0.3 & - & 0.1 \\
2 & - & 0.3 & - & 0.3
\end{tabular}


Table 4-3. C'ntd.

\section{TAXON}

Mastogloia elliptica (Agardh) Cleve

Staurosira construens Ehrenberg

Staurosirella pinnata var. pinnata (Ehrenberg) Williams \& Round

Synedra acus var. angustissima Ehrenberg

Navicula sp. 2

Mastogloia lanceolata Thwaites ex. W. Smith

Rhopalodia gibba (Ehrenberg) O. Muller

Amphora holsatica Hustedt

Amphora sp.7

Brachysira aponina Kützing

Brachysira procera Lange-Bertalot \& Moser

Brachysira pseudoexilis Lange-Bertalot \& Moser

Brachysira serians (Brebisson ex Kutzing) Round \& Mann

Brachysira vitrea (Grunow) Ross

Cyclotella pseudostelligera

Cymbella sp. 1

Encynoconposis sp. 1

Encyonema silesiacum var. elegans Krammer

Encyonema sp. 1

Encyonema sp. 2

Encyonema sp. 4

Eunotia incisa W. Smith ex. Gregory

\begin{tabular}{cccccccc} 
N & \multicolumn{3}{c}{ Average \% abundance } & \multicolumn{2}{c}{ TP Opt (Tol) } & I \\
& E & B & M & J & E & & \\
2 & - & 3.5 & - & 2.0 & & \\
2 & - & 1.9 & - & 0.5 & & \\
2 & - & 5.5 & - & 0.1 & & \\
2 & - & 0.6 & - & 0.1 & & \\
2 & - & 0.7 & - & 0.1 & & \\
2 & 1.2 & - & 9.4 & - & & \\
2 & 0.4 & - & - & 3.9 & & \\
1 & 0.6 & - & - & - & & \\
1 & 0.4 & - & - & - & & \\
1 & 0.5 & - & - & - & & \\
1 & 0.9 & - & - & - & & \\
1 & 1.5 & - & - & - & & $*$ \\
1 & 0.2 & - & - & - & & \\
1 & 0.7 & - & - & - & & \\
1 & 0.6 & - & - & - & & \\
1 & 0.7 & - & - & - & \\
1 & 0.4 & - & - & - & \\
1 & 1.7 & - & - & - & \\
1 & 0.6 & - & - & - & \\
1 & 0.3 & - & - & - & \\
1 & 0.9 & - & - & - & \\
1 & 0.4 & - & - & - & &
\end{tabular}


Table 4-3. C'ntd.

\section{TAXON}

Eunotia naegelii Migula

Eunotia sp. 1

Fragilaria cf. ulna (Nitzsch) Lange-Bertalot

Fragilaria sp. 1

Fragilariforma virescens var. capitata (Ralfs) Williams \& Round

Gomphonema auritum Braun

Gomphonema coronatum Ehrenberg

Gyrosigma obscurum (W. Smith) Griffith \& Henfrey

Navicula radiosafallax Lange-Bertalot

Nitzschia amphibia (Grunow) Lange-Bertalot

Nitzschia cf. obtusa

Pauliella taeniata (Grunow) Round \& Basson

Pinnularia cf. gibba

Pinnularia sp. 5

Pinnularia stomatophora (Grunow) Cleve

Pinnularia viridiformis Krammer

Sellaphora sp. 1

Stauroneis javanica (Grunow) Cleve

Stauroneis phoenicentron (Nitzsch) Ehrenberg

Anomoneis cf. sphaerophora morph 2

Aulacoseira granulata (Ehrenberg) Simonsen

Brachysira pumila Metzeltin \& Lange-Bertalot

Caloneis sp. 1

\begin{tabular}{cccccccc} 
N & \multicolumn{3}{c}{ Average \%abundance } & \multicolumn{2}{c}{ TP Opt (Tol) } & I \\
& E & B & M & J & E & C \\
1 & 0.4 & - & - & - & & \\
1 & 0.8 & - & - & - & & \\
1 & 0.9 & - & - & - & & \\
1 & 0.4 & - & - & - & & \\
1 & 0.5 & - & - & - & & \\
1 & 0.4 & - & - & - & & $* *$ \\
1 & 0.4 & - & - & - & & \\
1 & 0.3 & - & - & - & & \\
1 & 0.6 & - & - & - & & \\
1 & 0.8 & - & - & - & & \\
1 & 0.7 & - & - & - & & \\
1 & 0.7 & - & - & - & & \\
1 & 0.5 & - & - & - & & \\
1 & 0.5 & - & - & - & & \\
1 & 0.4 & - & - & - & \\
1 & 0.4 & - & - & - & \\
1 & 0.4 & - & - & - & \\
1 & 0.6 & - & - & - & \\
1 & 0.3 & - & - & - & \\
1 & - & 0.5 & - & - & \\
1 & - & 3.0 & - & - & \\
1 & - & 16.4 & - & - & \\
1 & - & 0.3 & - & - &
\end{tabular}


Table 4-3. C'ntd.

\section{TAXON}

Craticula cuspidata (Kützing) Mann

Craticula sp.1

Cymbella aspera (Ehrenberg) Cleve

Epithemia sp. 1

Eunotia flexuosa (Brébisson) Kützing_2

Eunotia implicata Nörpel, Lange-Bertalot \& Alles

Eunotia sp. 5

Eunotia sp. 6

Eunotia sp. 9

Fallacia pygmaea (Kützing) Stickle \& Mann

Gomphonema parvulum (Kützing) Grunow

Gomphonema sp. 1

Hantzschia spectabilis (Ehrenberg) Hustedt

Mastogloia elliptica var. dansei (Thwaites) Cleve

Navicula brasiliana (Cleve) Cleve

Navicula constans Hustedt

Navicula densilineolata (Lange-Bertalot) Lange-Bertalot

Neidium cf. densestriata Hustedt

Nitzschia scalaris (Ehrenberg) W. Smith

Pinnularia acrosphaeria (Brébisson) W. Smith

Pinnularia neomajor

Pinnularia sp. 3

1
1
1
1
1
1
1
1
1
1
1
1
1
1
1
1
1
1
1
1
1
1

\begin{tabular}{cccc}
\multicolumn{5}{c}{ Average \% abundance } \\
E & B & M & J \\
- & 0.2 & - & - \\
- & 0.2 & - & - \\
- & 0.7 & - & - \\
- & 0.7 & - & - \\
- & 0.4 & - & - \\
- & 0.3 & - & - \\
- & 0.2 & - & - \\
- & 0.5 & - & - \\
- & 0.2 & - & - \\
- & 1.4 & - & - \\
- & 0.2 & - & - \\
- & 3.5 & - & - \\
- & 0.2 & - & - \\
- & 0.8 & - & - \\
- & 0.4 & - & - \\
- & 0.4 & - & - \\
- & 0.2 & - & - \\
- & 0.2 & - & - \\
- & 0.2 & - & - \\
- & 0.3 & - & - \\
- & 0.2 & - & - \\
- & 0.4 & - & -
\end{tabular}

TP Opt (Tol)

E 
Table 4-3. C'ntd.

\section{TAXON}

Pinnularia stoermeri

Pinnularia streptoraphe

Sellaphora pupula var. aquaeductae

Stauroneis phoenicentron

Stauroneis smithii Grunow

Surrirella elegans Ehrenberg

Unknown species 05

Amphora cymbifera var. heritierarum Wachnicka \& Gaiser

Amphora sp.3

Amphora sp.6

Amphora sp.8

Anomoneis sphaerophora (Ehrenberg) Pfitzer

Brachysira cf. hofmanniae Lange-Bertalot

Cyclotella litoralis Lange \& Syvertsen

Diploneis sp. 2

Hantzschia vivacior Lange-Bertalot

Mastogloia braunii Grunow

Mastogloia sp. 4

Navicula palistinae Gerloff, Natour \& Rivera

Navicula palistinae morph 2

Navicula pseudocrassirostris Hustedt

Navicula sp. 5

Navicula sp. 6

\begin{tabular}{ccccr} 
N & \multicolumn{5}{c}{ Average \% abundance } \\
& E & B & M & J \\
1 & - & 0.2 & - & - \\
1 & - & 0.3 & - & - \\
1 & - & 0.2 & - & - \\
1 & - & 0.4 & - & - \\
1 & - & 0.7 & - & - \\
1 & - & 0.9 & - & - \\
1 & - & 0.2 & - & - \\
1 & - & - & 0.5 & - \\
1 & - & - & 0.2 & - \\
1 & - & - & 0.5 & - \\
1 & - & - & 0.2 & - \\
1 & - & - & 0.2 & - \\
1 & - & - & 1.1 & - \\
1 & - & - & 0.2 & - \\
1 & - & - & 0.4 & - \\
1 & - & - & 0.2 & - \\
1 & - & - & 1.0 & - \\
1 & - & - & 0.3 & - \\
1 & - & - & 1.3 & - \\
1 & - & - & 0.2 & - \\
1 & - & - & 2.7 & - \\
1 & - & - & 0.2 & - \\
1 & - & - & 1.2 & -
\end{tabular}

TP Opt (Tol)

E 
Table 4-3. C'ntd.

\section{TAXON}

Nitzschia sp. 2

Nitzschia sp. 4

Pinnularia sp. 2

Pleurosigma sp. 1

Proschkinia sp. 1

Seminavis eulensteinii (Grunow) Danielidis, Ford \& Kennett Actinocyclus normanii (Gregory ex Greville) Hustedt

Diploneis sp. 3

Diploneis sp. 4

Diploneis sp. 5

Encyonema jemtlandicum var. venezolanum Krammer

Encyonema sp. 3

Encyonema vulgare var. vulgare Krammer

Fragilaria (?) sp. 1 cf. famelica (Kützing) lange-Bertalot

Mastogloia cf. braunii

Navicula sp. 1

Navicula sp. 7

Neidium sp. 1 cf. juba

Nitzschia sp. 5

Nitzschia sp. 6

Nitzschia thermaloides Hustedt

Pinnularia sp. 4

Tabularia tabulata (Agardh) Snoeijs

\begin{tabular}{ccccc}
$\mathrm{N}$ & \multicolumn{4}{c}{ Average \% abundance } \\
& $\mathrm{E}$ & $\mathrm{B}$ & $\mathrm{M}$ & $\mathrm{J}$ \\
1 & - & - & 0.9 & - \\
1 & - & - & 2.2 & - \\
1 & - & - & 0.6 & - \\
1 & - & - & 0.3 & - \\
1 & - & - & 1.5 & - \\
1 & - & - & 0.2 & - \\
1 & - & - & - & 0.3 \\
1 & - & - & - & 0.2 \\
1 & - & - & - & 0.2 \\
1 & - & - & - & 0.2 \\
1 & - & - & - & 4.0 \\
1 & - & - & - & 0.8 \\
1 & - & - & - & 1.1 \\
1 & - & - & - & 1.7 \\
1 & - & - & - & 0.5 \\
1 & - & - & - & 0.2 \\
1 & - & - & - & 0.4 \\
1 & - & - & - & 0.1 \\
1 & - & - & - & 0.4 \\
1 & - & - & - & 0.5 \\
1 & - & - & - & 0.5 \\
1 & - & - & - & 0.1 \\
1 & - & - & - & 0.7
\end{tabular}

TP Opt (Tol)

E 
Table 4-4. Average per-site species richness $(\mathrm{S})$ and diversity $(\mathrm{H})$ for all locations. Standard deviations are indicated in parentheses. Significantly low values $(\mathrm{p}<0.001)$ are indicated with an asterisk $(*)$.

\begin{tabular}{lcccc}
\hline \multicolumn{1}{c}{ Site } & No. of samples & $\begin{array}{c}\text { Total no. of } \\
\text { species }\end{array}$ & $\mathrm{S}$ & $\mathrm{H}$ \\
\hline Belize & 21 & 113 & $18.48(6.51)$ & $1.67(0.49) *$ \\
Mexico & 10 & 84 & $18.70(4.45)$ & $2.00(0.33)$ \\
Jamaica & 10 & 87 & $21.90(4.41)$ & $2.01(0.22)$ \\
Everglades & 134 & 87 & $14.88(3.40) *$ & $1.59(0.30) *$ \\
\hline
\end{tabular}




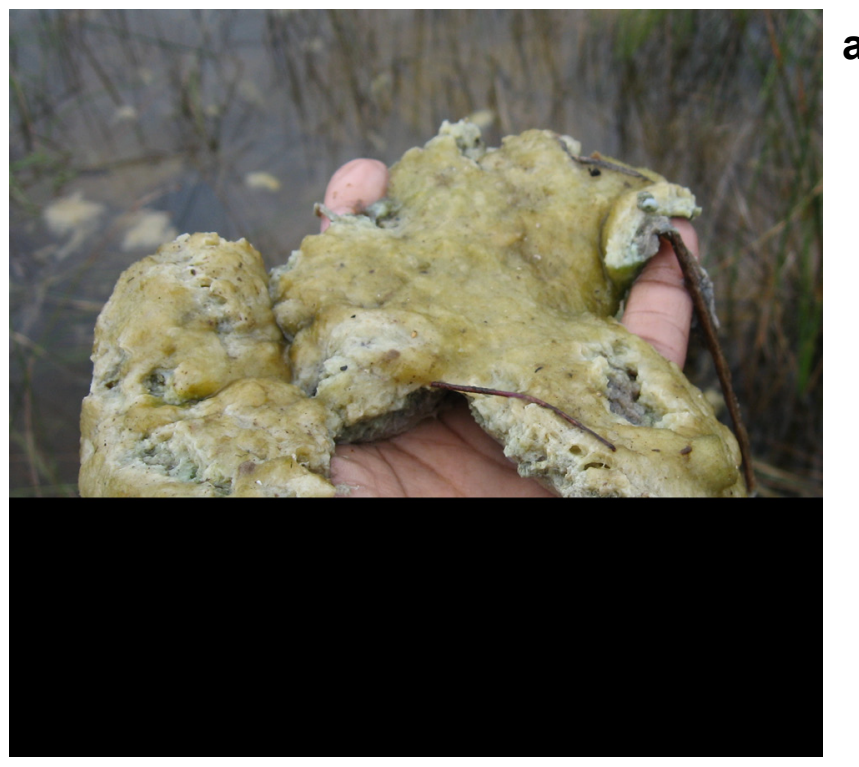

a

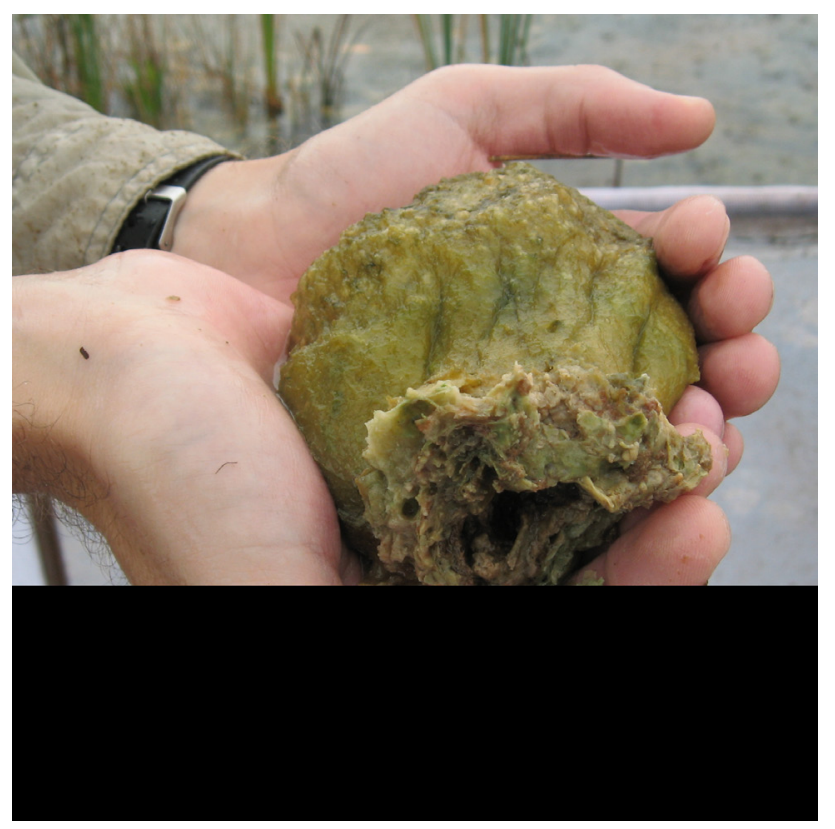

b

Figure 4-1. Benthic (a) and epiphytic (b) periphyton mat specimens collected from karstic marsh habitats. 


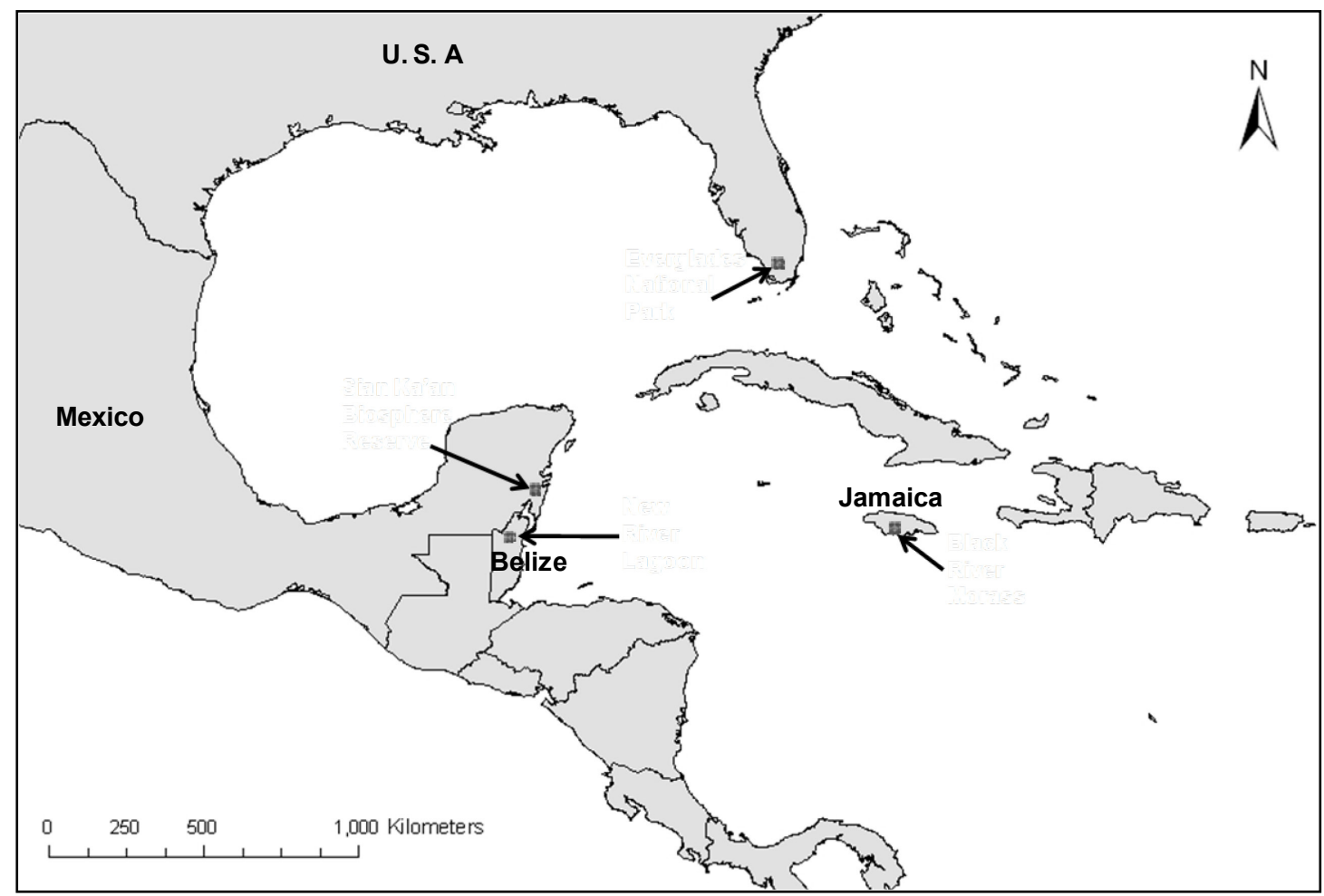

Figure 4-22. Map of northern Caribbean region showing the four sampling locations for this study. 


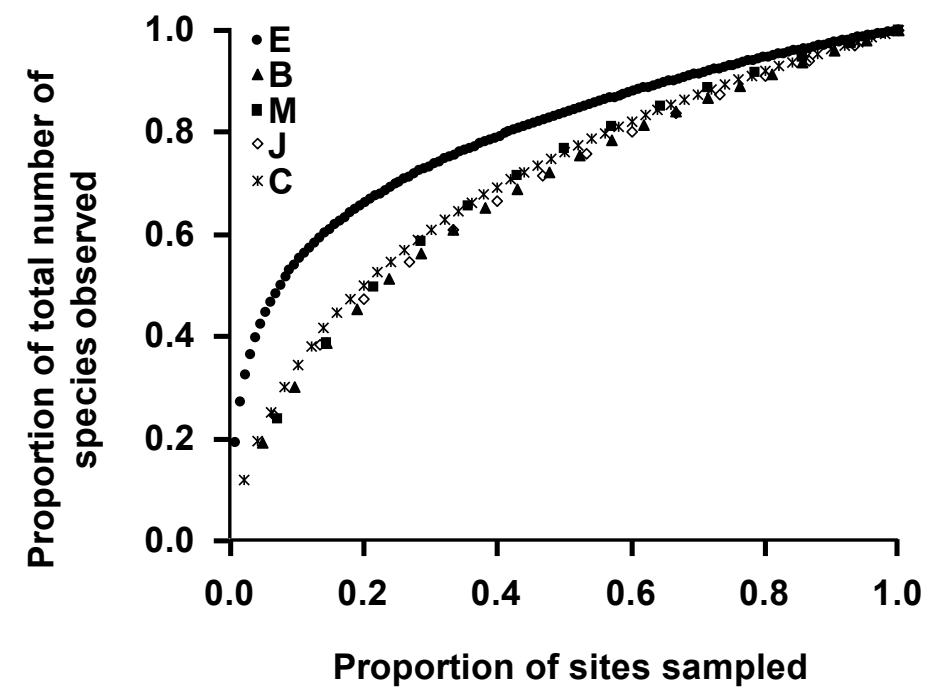

Figure 4-3. Rarefaction curves generated for Everglades samples (E), Belize samples (B), Mexico samples (M), Jamaica samples (J) and a composite of the Caribbean samples (C).

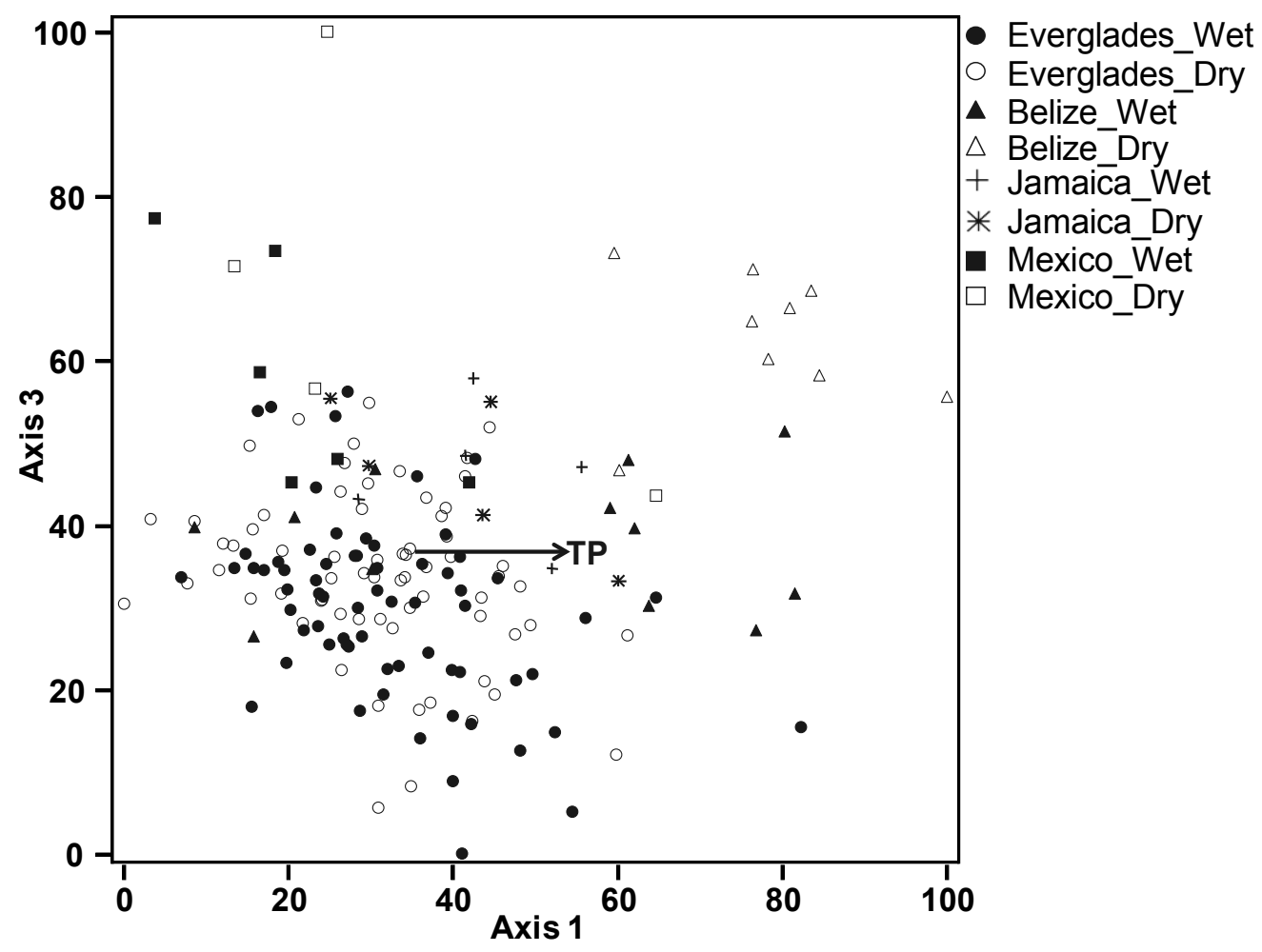

Figure 4-4. NMDS plot showing dissimilarity between diatom assemblages from Everglades (E), Belize (B), Mexico (M) and Jamaica (J) locations (Stress $=0.17)$. The vector representing the direction and strength of the relationship between mat TP and diatom assemblage dissimilarity is shown. 


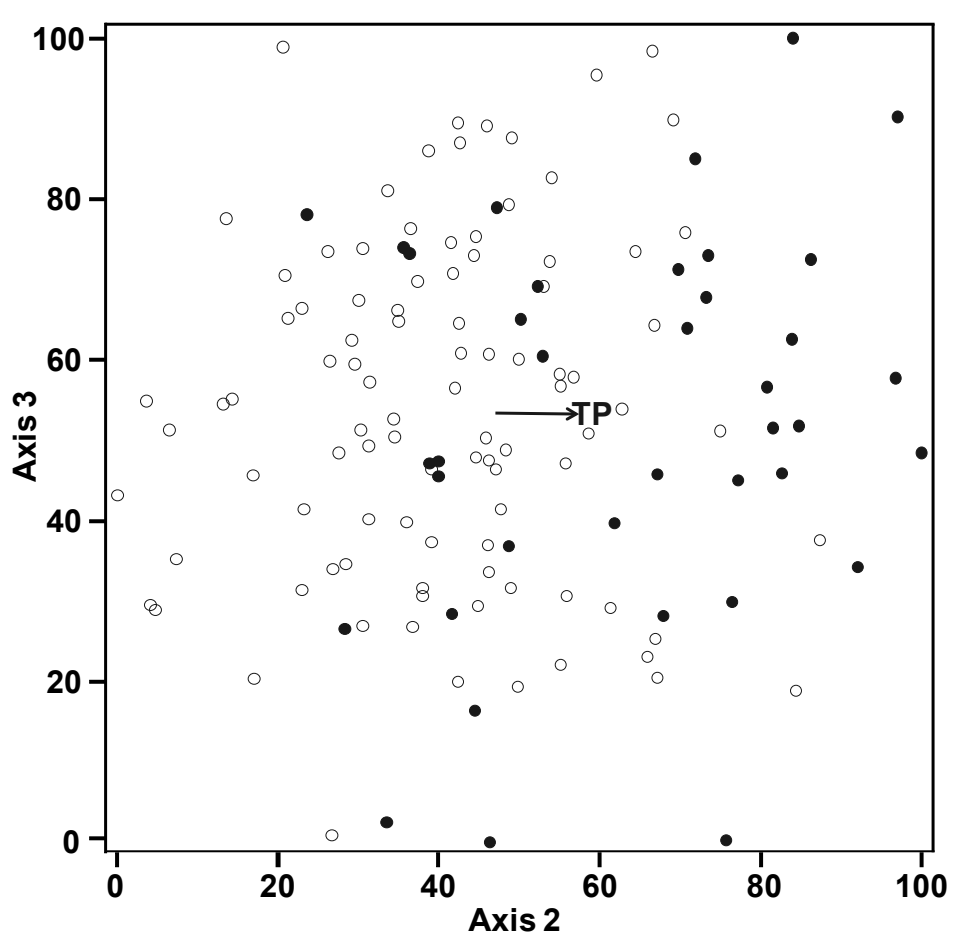

b

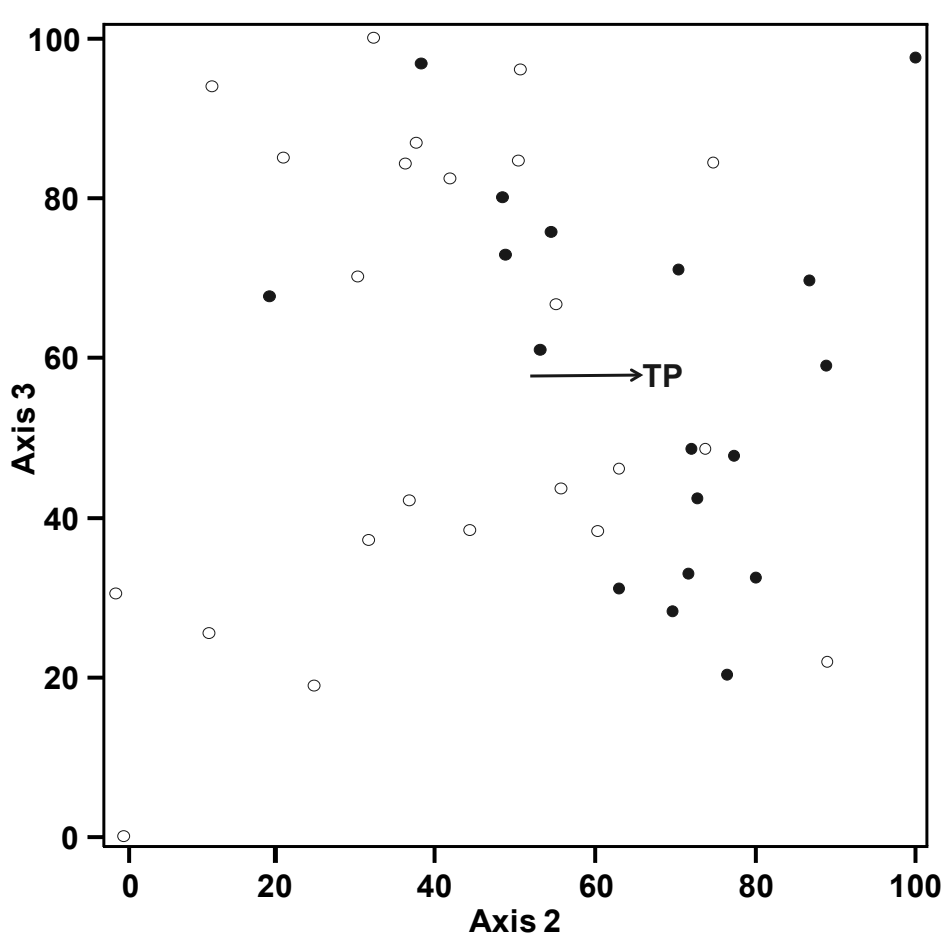

High TP

O Low TP

Figure 4-5. NMDS plot showing dissimilarity between "high" and "low" TP diatom assemblages from (a) Everglades (Stress = 0.19 ), (b) a composite of the Caribbean locations (Stress $=0.12$ ). The vector representing the direction and strength of the relationship between mat TP and diatom assemblage dissimilarity is shown 


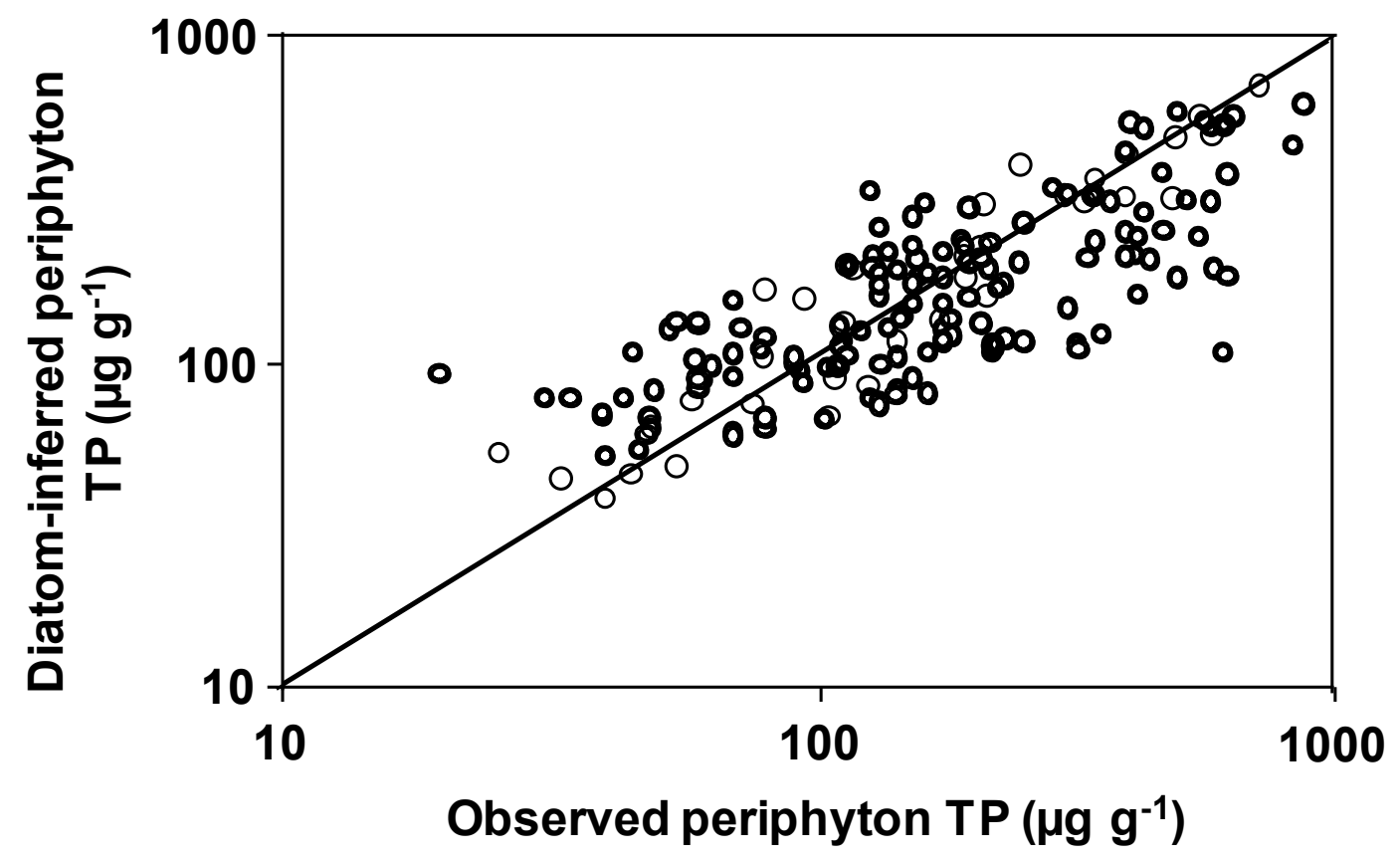

Figure 4-6. Scatter plot showing the relationship between diatom inferred periphyton mat TP concentrations and observed periphyton mat TP concentrations for Caribbean $(\mathbf{\bullet})\left(\mathrm{R}^{2}\right.$ $\left.=0.85, \mathrm{RMSE}=66.1 \mu \mathrm{g} \mathrm{TP} \mathrm{g}^{-1}\right)$ and Everglades $(\mathbf{O})$ sites $\left(\mathrm{R}^{2}=0.56, \mathrm{RMSE}=113.4 \mu \mathrm{g}\right.$ $\left.\mathrm{TP}^{-1}\right)$. 

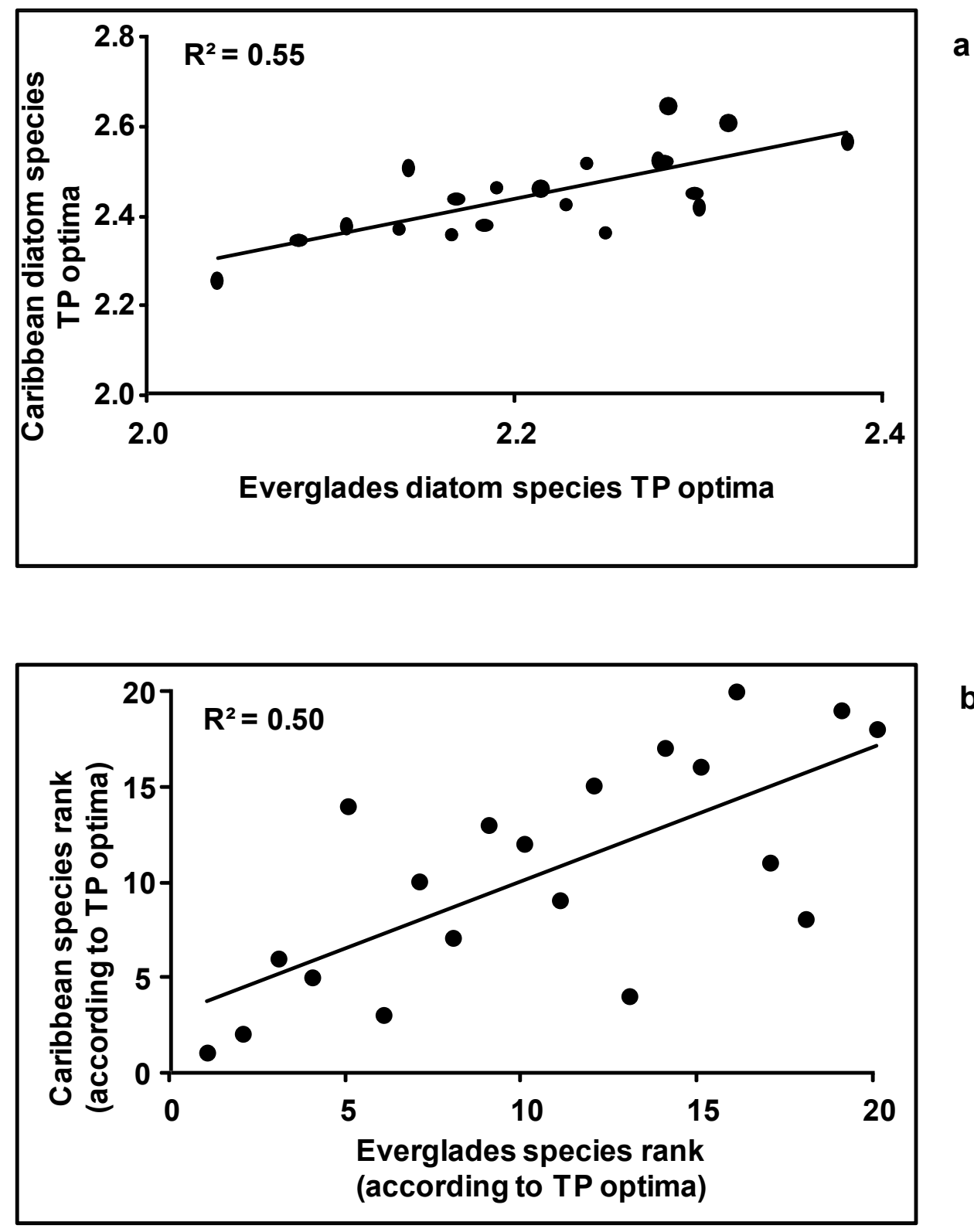

b

Figure 4-7. Scatter plot showing (a) the relationship between Everglades and Caribbean diatom species TP optima $\left(\mathrm{R}^{2}=0.55\right)$ and $(\mathrm{b})$ the relationship between Everglades and Caribbean ranked diatom species TP optima $\left(R^{2}=0.55\right)$. 


\section{CHAPTER V}

\section{General Conclusions}

Regional wetland degradation as a result of agricultural and industrial activities is increasing and effective techniques to aid in wetland monitoring and management are greatly needed. Diatoms have proven to be a highly effective tool for use in monitoring water quality changes, and within the Everglades, where periphyton mats are noted for their high standing crop and productivity, as well as their response to changes in hydrology and water quality, models have already been developed which allow diatoms to be used for inferring changes in phosphorus availability within the system. The potential exists for using diatoms in this capacity in karstic wetlands throughout the Caribbean and Central American region, but this is contingent on the availability of baseline information and an understanding of the dynamics of periphyton mats in these habitats. This current study addressed these needs.

In Chapter II, (i) positive relationships between water depth and mat organic content and (ii) negative relationships between periphyton mat total phosphorus (TP) concentrations and biomass were identified in Everglades marshes. These relationships were also demonstrated at a number of similar karstic wetland habitats in Belize, Mexico and Jamaica, therefore strongly corroborating the patterns observed in the Everglades, and providing evidence to support the idea that the observed relationships are indeed characteristic of tropical karstic wetlands and not unique to the Everglades system. This 
has effectively shown that water depth and, to a greater extent, periphyton TP content, are both drivers for periphyton dynamics in these systems.

Periphytic diatom assemblages are known to be extremely sensitive to changes in water chemistry. In the Everglades, established relationships between periphytic diatom assemblages and TP have been used to develop diatom based calibration models to infer water, soil and periphyton mat TP concentrations, as well as to indicate past environmental conditions and identify anthropogenically driven changes to the system using paleoecological techniques. These techniques can be employed in similar systems provided there is adequate information regarding (i) the species composition of local assemblages and (ii) the response of these assemblages to changes in water quality.

The first of these issues was addressed in Chapter III, which provides a taxonomic inventory of the diatom species associated with calcitic periphyton mats from karstic wetlands within the region. This comprehensive species list, along with photomicrographs, morphological descriptions and autecological information, provide the first account of diatom species from these habitats in Belize and Jamaica, and supplement the information from the single study conducted in the Yucatan region of Mexico. This taxonomic study has also identified a distinctive assemblage of diatom species (including Brachysira neoexilis, Encyonema evergladianum, Encyonema spp., Fragilaria syngrotesca, Mastogloia smithii var. lacustris, Mastogloia smithii, Navicula cryptotenella, Nitzschia palaea and Nitzschia serpentiraphe) which occurred across all locations. This assemblage, though commonly found in periphyton mats within Everglades marshes, has not been reported from other habitat types and is therefore possibly endemic to subtropical/tropical freshwater karstic wetlands. 
The second issue, which involves an examination of the response of periphytic diatom assemblages to changes in water quality, was addressed in Chapter IV. The diatom assemblages from periphyton mats in Everglades, Belize, Mexico and Jamaica marshes all changed in relation to periphyton mat TP concentrations, such that "low" and "high" TP assemblages could be identified. Despite the fact that species composition overlapped across locations and weighted averaging models effectively predicted mat TP concentrations from diatom assemblages for both Everglades $\left(\mathrm{R}^{2}=0.56\right)$ and Caribbean $\left(\mathrm{R}^{2}=0.85\right)$ locations, there were significant differences among Everglades and Caribbean locations with respect to species TP optima and indicator species. These results highlight two important points. The first is that diatoms do serve as effective indicators of water quality in karstic wetlands within the Caribbean region. The second is that despite the similarity among systems and the overlapping diatom species assemblage, the specific response of individual species to changing water quality can differ among systems. As such, caution is necessary when attempting to apply a single diatom-based inference model across systems, as variations in the response of species to water quality reduces the accuracy of model based predictions. 
VITA

JOSETTE M. LA HÉE

July $19^{\text {th }}, 1976$

1997

2001

$2001-2003$

2003

2010
Born, Port of Spain, Trinidad

B.Sc., Botany/Zoology

University of the West Indies

Mona, Jamaica

M.Phil., Botany

University of the West Indies

Mona, Jamaica

Environmental Officer

National Environment and Planning Agency

Kingston, Jamaica

Junior Lecturer (Botany)

Department of Life Sciences

University of the West Indies

Mona, Jamaica

Doctoral candidate in Biology

Department of Biological Sciences

Florida International University

Miami, Florida

\section{$\underline{\text { ACADEMIC PUBLICATIONS }}$}

Evelyn Gaiser, Josette M. La Hée, Franco A. C. Tobias, Anna H. Wachnicka (2010) "Mastogloia smithii var. lacustris Grun.: A structural engineer of calcareous mats in karstic subtropical wetlands" Proceedings of the Academy of Natural Sciences of Philadelphia (in press)

Josette M. La Hée, Evelyn E. Gaiser, Joel C. Trexler, William F. Loftus. "Phosphorus and hydrology as drivers of periphyton biomass in four tropical karstic wetland systems" Wetlands (in prep)

Josette M. La Hée, Evelyn E. Gaiser. "Phosphorus effects on diatom community composition and dynamics in four tropical karstic wetland systems" Journal of the North American Benthological Society (in prep) 


\section{$\underline{\text { ACADEMIC PRESENTATIONS }}$}

Phosphorus and hydrology as drivers of periphyton biomass in the Everglades and three tropical karstic wetlands.

Oral Presentation

95th Meeting of the Ecological Society of America, Pittsburgh, Pennsylvania, U.S.A.

J. M. La Hée and E. E. Gaiser, August 2010

The use of diatom communities as indicators of water quality in four tropical, karstic wetland systems

Oral Presentation

94th Meeting of the Ecological Society of America, Albuquerque, New Mexico, U.S.A.

J. M. La Hée and E. E. Gaiser, August 2009

"Sister systems: Comparisons of diatom communities from the Florida Everglades and the Black River Morass, Jamaica."

Oral Presentation

$19^{\text {th }}$ North American Diatom Symposium, Pellston, Michigan, U.S.A.

J. M. La Hée and E. E. Gaiser, September, 2007

"The effects of rum distillery effluent on the periphytic diatom community of the North Elim River, St. Elizabeth, Jamaica"

Oral Presentation

$17^{\text {th }}$ North American Diatom Symposium, Florida, U.S.A.

Josette La Hée, October, 2003

"The effects of rum distillery effluent on the macroinvertebrate and periphytic diatom community of the North Elim River, St. Elizabeth, Jamaica"

Oral presentation

Proceedings of the $12^{\text {th }}$ Caribbean Academy of Sciences Conference, Havana, Cuba. Josette La Hée, Kimberly John, Eric Hyslop, Dale Webber, April, 2000

\section{$\underline{\text { AWARDS AND GRANTS }}$}

- Phycological Society of America Grant in Aid of Research 2007

- Latin American and Caribbean Center Research Travel Grant 2006

- Society of Wetland Scientists 2006

- Garden Club of America Scholarship 2006

- Iowa Lakeside Laboratory Merit Scholarship (2004)

- Christina Menendez Fellowship for Everglades Research 2004 